\title{
Global (environmental) change and tourism : issues of scale and distribution
}

Citation for published version (APA):

Amelung, S. B. (2006). Global (environmental) change and tourism : issues of scale and distribution. [Doctoral Thesis, Maastricht University]. Datawyse / Universitaire Pers Maastricht. https://doi.org/10.26481/dis.20060331sa

Document status and date:

Published: 01/01/2006

DOI:

10.26481/dis.20060331sa

Document Version:

Publisher's PDF, also known as Version of record

\section{Please check the document version of this publication:}

- A submitted manuscript is the version of the article upon submission and before peer-review. There can be important differences between the submitted version and the official published version of record.

People interested in the research are advised to contact the author for the final version of the publication, or visit the DOI to the publisher's website.

- The final author version and the galley proof are versions of the publication after peer review.

- The final published version features the final layout of the paper including the volume, issue and page numbers.

Link to publication

\footnotetext{
General rights rights.

- You may freely distribute the URL identifying the publication in the public portal. please follow below link for the End User Agreement:

www.umlib.nl/taverne-license

Take down policy

If you believe that this document breaches copyright please contact us at:

repository@maastrichtuniversity.nl

providing details and we will investigate your claim.
}

Copyright and moral rights for the publications made accessible in the public portal are retained by the authors and/or other copyright owners and it is a condition of accessing publications that users recognise and abide by the legal requirements associated with these

- Users may download and print one copy of any publication from the public portal for the purpose of private study or research.

- You may not further distribute the material or use it for any profit-making activity or commercial gain

If the publication is distributed under the terms of Article $25 \mathrm{fa}$ of the Dutch Copyright Act, indicated by the "Taverne" license above, 


\section{Global (Environmental) Change and Tourism}

Issues of scale and distribution

Sebastiaan Bartholomeus Amelung 
Cover graphics:

Background: Beach near Tallinn, Estonia; September 2005

Picture: $\quad$ Tourists at Elmina Castle, Ghana; December 2005

Map: $\quad$ Projected number of months with very good climatic conditions for tourism (Mieczkowski's tourism climatic index $>70$ ) in northwestern Europe in the period 2070-2100, based on an integration of the HadCM3 climate model with the SRES A1F scenario.

Copyright $\odot 2006$ S.B. Amelung, Maastricht

ISBN-10: 90-810548-1-3

ISBN-13: 978-90-810548-1-2

Amelung Publishers, www.amelung.nl

Production: Datawyse | Universitaire Pers Maastricht 


\section{Global (Environmental) Change and Tourism}

Issues of scale and distribution

\section{PROEFSCHRIFT}

ter verkrijging van de graad van doctor

aan de Universiteit Maastricht, op gezag van de Rector Magnificus,

Prof. Mr. G.P.M.F. Mols,

volgens het besluit van het College van Decanen,

in het openbaar te verdedigen

op vrijdag 31 maart 2006 om 12.00 uur

door

Sebastiaan Bartholomeus Amelung 
Promotores:

Prof. dr. W.J.M. Martens

Prof. dr. ir. J. Rotmans, Erasmus Universiteit Rotterdam

Beoordelingscornmissie:

Prof. dr. J.H. Stel (voorzitter)

Dr. A.H. Perry, University of Wales, Swansea

Prof. dr. L.L.G. Soete

Dr. D. Viner, University of East Anglia, Norwich

This research was supported by the Center for Integrated Study of the Human Dimensions of Global Change, through a cooperative agreement between the National Science Foundation (SBR-9521914) and Carnegie Mellon University. 



\section{The challenge of Integrated Assessment An early 19 th century source of inspiration}

\section{Natur und Kunst \\ Johann Wolfgang von Goethe (1802)}

Natur und Kunst, sie scheinen sich zu fliehen

Und haben sich, eh' man es denkt, gefunden:

Der Widerwille ist auch mir verschwunden.

Und beide scheinen gleich mich anzuziehen.

Es gilt wohl nur ein redliches Bemuhen!

Und wenn wir erst, in abgemessnen Stunden, Mit Geist und Fleiß uns an die Kunst gebunden,

Mag frei Natur im Herzen wieder glühen.

So ist"s mit aller Bildung auch beschaffen.

Vergebens werden ungebundne Geister

Nach der Vollendung reiner Höhe streben.

Wer Großes will, muss sich zusammenraffen. In der Beschrânkung zeigt sich erst der Meister. Und das Gesetz nur kann uns Fireiheit geben.
Nature and Art

Translated by Tessa Ransford

Nature and Art appearing disparate

Are found as one beneath our very eyes:

No incongruity to my surprise,

For each seems equally to fascinate.

This requires supreme, sustained endeavour, Devotion to our craft, unceasing practice With heart and mind; then only may we withess Nature kindle again as free as ever.

Nothing is built, created, without Laws: Nor is perfection reached without restriction; And fullest grace demands most discipline.

We must contain ourselves to win applause: The Master is discerned within constriction; And visions are in vain without design. 



\section{Contents}

PART ONE INTRODUCTION AND METHODOLOGICAL FRAMEWORK 1

Chapter 1 Introduction 3

1.1 Globalisation and tourism 5

1.2 The vortex of globalisation and global tourism $\quad 7$

1.3 Tourism as a driving force behind globalisation 7

1.4 Scope and objectives 9

1.5 Outline $\quad: \quad 12$

References 13

$\begin{array}{lll}\text { Chapter } 2 \text { Methodological framework } & 17\end{array}$

2.1 Tourism: a complex system $\quad 19$

2.2 Integrated Assessment $\quad 20$

2.3 Tourism, complexity and Integrated Assessment 20

2.4 The Integrated Assessment toolbox 23

2.5 Decision-making in the face of complexity 28

2.6 Research approach $\quad \cdots \quad 29$

References $\quad 32$

PART TWO TOURISM: HISTORY AND CURRENT ISSUES 37

$\begin{array}{lll}\text { Chapter } 3 \quad \text { Global tourism: an overview } & 39\end{array}$

3.1 Introduction $\quad 41$

3.2 Definitions of tourism $\quad 41$

3.3 The scale of tourism 43

3.4 Driving forces $\quad 44$

3.5 Impacts

3.6 Temporal and spatial concentration $\quad 58$

References. 61

Chapter 4 Structural barriers to socially sustainable tourism development: evidence from Mombassa Old Town 65

4.1 Introduction $\quad 67$

4.2 Sustainable tourism and its tensions 67

4.3 An introduction to cultural tourism in Mombassa 69

4.4 Socio-effectiveness, socio-efficiency and staging 72

4.5 Staging and socio-efficiency in Mombassa Old Town 70

$\begin{array}{ll}4.6 \text { Discussion and conclusions } & 78\end{array}$

$\begin{array}{ll}\text { References } & 79\end{array}$ 
Chapter 5 The future of tourism: a scenario analysis

5. Introduction

5.2 Scenario analysis and tourism $\quad 85$

5.3 Looking ahead - the future of tourism 88

5.4 Towards sustainable tourism $\quad 92$

5.5 Conclusions $\quad 96$

$\begin{array}{ll}\text { References } & 97\end{array}$

Chapter 6 Exploring the impacts of climate change on tourism: analyses with tourism climatic indices 99

6.1 Introduction

$\begin{array}{ll}6.2 \text { Tourism climatic indices } & 104\end{array}$

6.3 Data and Methods $\quad 108$

6.4 Results 114

6.5 Balearics case study $\quad 125$

6.6 Discussion $\quad 130$

Acknowledgements $\quad 133$

$\begin{array}{ll}\text { References } & 133\end{array}$

Chapter 7 The consequences of climate change for tourism and recreation in a Dutch context

7.1 Introduction

$\begin{array}{ll}7.2 \text { Weather, climate, tourism and recreation } & 139\end{array}$

7.3 Research methodology 141

7.4 Effects on tourism and recreation in the Netherlands $\quad 145$

7.5 Implications for outbound tourism $\quad 149$

7.6 Discussion and conclusions $\quad 152$

$\begin{array}{ll}\text { References } & 154\end{array}$

Chapter 8 Taxing aviation: historical background and future perspectives $\quad 157$

8.1 Introduction $\quad 159$

8.2 The position of international aviation in international treaties 159

8.3 The cradle of commercial aviation and its fiscal regime: the USA 162

8.4 International developments $\quad 165$

8.5 Future perspectives $\quad 172$

8.6 Discussion and conclusions $\quad 179$

$\begin{array}{ll}\text { References } & 180\end{array}$ 
Chapter $9 \quad$ Discussion and conclusions

9.1 Objectives

9.2 Conclusions and reflection 185

9.3 Future research

References

Samenvatting

Dankwoord \& Acknowledgements

203

Curriculum vitae

209 

PART ONE

Introduction and methodological framework 

Chapter 1

Introduction 



\subsection{Globalisation and tourism}

Over the latter half of the 20th century, tourism has grown to be one of the world's major industries, and one of the most striking societal phenomena. According to the World Tourism Organisation (WTO $)$, the number of international tourists has grown by a factor of 30 between 1950 and today, reaching 808 million visitors in 2005 (UNWTO, 2006). And this is just the tip of the iceberg, since the volume of domestic tourism is known to greatly exceed that of international tourism.

The stormy development of tourism cannot be properly understood in isolation. It is closely linked to many other developments in society on levels ranging from the global to the local. The first developments that spring to mind are technological innovations. Traditional forms of land and water transport were too slow to reach distant destinations in an acceptable period of time. Only the very rich could afford to be away from home for extensive periods of time. Among the 18th century British aristocracy, the Grand Tour of Europe was considered to be an essential part of the upbringing of the educated, but for ordinary citizens such tours were unimaginable. The development of railways and automobiles enabled people to cover medium distances in relatively short time spans, while the introduction of passenger aircraft allowed people to travel long distances for leisure purposes. Secondary, marginal innovations in transport technology made medium and long haul travelling progressively cheaper and more affordable for tourism purposes.

Increasing disposable incomes in the developed countries reinforced the effect of decreasing transport prices. Per capita income in the high-income OECD countries, expressed in purchasing power parities (PPP), rose from just over $\$ 7,000$ in 1950 to close to $\$ 31,000$ in 2004 (GGDC, 2005). This economic success has been fuelled by the growth of international trade. For the first four decades after the Second World War, trade relations were governed by the General Agreement on Tariffs and Trade (GATT), adopted in 1948 by 23 of the world's trading nations. Since then, eight rounds of negotiations lowered average industrial tariffs from 40 percent to less than 4 percent. The most recent round led to the creation of the World Trade Organisation in 1995. Over the last sixty years, global trade flows increased over a hundredfold. Tourist flows followed suit, correlated as they are with trade relations (Harremoës and Turner, 2001). The capital market was also liberalised. As a result, foreign direct investment expanded enormously over the past thirty-five years. The resulting

\footnotetext{
'The World Tourism Organisation and the World Trade Organisation both use the acronym WTO. In this thesis, WTO always refers to the World Tourism Organisation.
} 
global stock of invested capital increased from virtually nothing in 1970 to around 8.2 thousand billion dollars in 2003. Foreign direct investment allowed many tourist destinations to increase their capacities much more rapidly than would have been possible without it.

In addition to the four-fold increase in per capita welfare over the last half century, total population in the high-income OECD countries increased by almost two thirds, from around 580 million in 1950 to 920 million in 2002 (UNDP, 2004). Population growth in the rest of the world was even stronger increasing from 2 billion people around 1950 to some 5.3 billion people today. Until today, the importance of these non-OECD countries for international tourism volumes has been limited. The group of OECD countries continues to dominate global tourism (WTO, 2003). With the economies of highly populous countries such as China and India growing at very high rates, however, the OECD may well lose its leading role within the next decades. The rapid urbanisation in developing countries intensifies this trend. Travel propensity in large cities is known to be considerably higher than in rural areas (Aguilo et al., 2005). Today, almost half the world population lives in urban areas. In the highincome countries of the OECD this share is $80 \%$, up from $70 \%$ in 1975 (UNDP, 2004).

Explanations for the urban-rural divide in tourist behaviour have been sought in the very different structures of urban and rural life (Kleeman et al., 2000). Unlike farmers, urban dwellers are not tied to the land. They work in urban industries that rely on an ongoing division of labour and specialisation for their development and survival. The increasing specialisation requires substantial coordination and harmonisation between the actors involved in it. This standardisation creates a difference between labour time and leisure time that is much more pronounced than in traditional agricultural societies. In addition, the division of labour invokes a sense of alienation from the final product and a longing for a romanticised simple and authentic life. The emergence of distinct leisure time and the search for authentic ways of life and experiences have been important socio-cultural driving forces behind tourism, and behind the emergence of its pronounced seasonal patterns. Think of the summer holiday period that is highly concentrated in a short period of time.

These seasonal patterns are of course also related to natural cycles, in particular in the temperate climatic zones of the earth. Despite their importance for annual tourism cycles, climatic factors are unlikely to have played a crucial role in the rapid growth of tourist volumes over the years. In the experience of tourists and the tourist industry, the climate has not changed in a noticeable way. Projections of climate change suggest that this may well change in the future (IPCC, 2001). Climate change is part of a series of developments, known 
as global environmental change, which also encompasses issues such as loss of biodiversity, and ozone depletion (Steffen et al, 2004). Landscape, nature and biodiversity - major objects of global environmental change - are often mentioned as key resources for tourism. There are few indications, however; that global environmental change is already impacting upon tourism volumes on a global scalle. It may nevertheless be changing tourism patterns.

\subsection{The vortex of globalisation and global tourism}

In summary, major driving forces behind tourism growth have been technological innovations, economic growth, institutional change and liberalisation, population growth, and urbanisation, and cultural change. These factors coincide with the ingredients of globalisation as conceptualised by Rennen and Martens (2003): "globalisation is the interactive co-evolution of millions of technological, cultural, economic, social and environmental trends at all conceivable spatiotemporal scales." This is no coincidence. Indeed, as the sociologist Urry (2002) notes:

\footnotetext{
"There are not two separate entities, the 'global' and 'tourism' bearing some external connections with each other. Rather they are part and parcel of the same set of complex and interconnected processes. There are countless ways in which huge numbers of people and places get caught up within the swirling vortex of global tourism."
}

This fragment hints at the strong (positive) feedback mechanisms that drive forward the complex processes underlying globalisation and tourism. It implies that an analysis of tourism growth should not be limited to identifying the main driving forces, because the effects of tourism development feed back into the development of these driving forces. Having become one of the world's largest sectors, tourism's feedbacks towards the elements of globalisation have become large and unmistakable.

\subsection{Tourism as a driving force behind globalisation}

Within the 'tourism system' itself, there are a number of positive feedback loops. Tourism has proved to be an excellent vehicle to signal one's social rank and status; it is one of the many areas of group life where fashion operates (Miller ett all., 1993). In fact, according to Prosser (1994), "tourism, in essence, is a fashion industry." To be an effective signal the fashion good must be more costly to obtain for those who do not possess the status than for those who do. After a while, however, fashion starts propagating through society. Therefore, if 
fashion is to be an effective signal of status, it must change (Coelho and Mcclure, 1993). This basic social mechanism partly explains the volatile nature of tourism, with new destinations emerging, flourishing and falling in disarray or struggling to rejuvenate.

The general tendency in tourism is to travel ever-longer distances. Busch and Luberichs (2001), as cited in Gossling (2002) show that travel distances strongly increase with income and education, both of which have grown substantially over the past half-century. Prosser (1994) described this expansion of tourism as a "tidal wave of the pleasure periphery", as more and more countries have come under the 'gaze' (Urry, 2002) of multitudes of temporary visitors. The combination of increasing numbers of tourists travelling over increasing distances has stimulated innovation in the transport sector and has resulted in the capitalisation on economies of scale. In 2001, leisure-related travel accounted for an estimated $35 \%$ of total global travel, while some evidence suggests that this percentage was around $50 \%$ in the industrialised countries (Gössling, 2002). In the segment of air travel, perhaps even 70 or $80 \%$ is leisure-related. It can be safely assumed that innovations such as the rise of low cost carriers would not have been possible without the tremendous growth of tourism. Tourism in turn, benefits from the decreasing prices. The rising popularity of long-haul travel and low-cost carriers have led to a change in modal split, in which the car is progressively being replaced by the aircraft as the tourists" favourite mode of transport.

The growth in numbers of tourists, distances travelled and the modal shift have made tourism a major and one of the most rapidly growing sources of greenhouse gas emissions. In 2001, leisure-related emissions accounted for an estimated $5.3 \%$ of global greenhouse gas emissions in terms of $\mathrm{CO}_{2}$ equivalents, of which almost $95 \%$ was transport-related (Gössling, 2002). Through these emissions, tourism may be contributing to the introduction of a new global determinant of tourism volumes: climate change.

Climate change will have a particularly strong impact on two major categories of tourist destinations: coasts and mountains. Around $70 \%$ of global tourism takes place in coastal zones, while mountainous areas capture another major share of the market. The fragile environments of coastal zones and mountainous regions are also among the areas that are most vulnerable to climate change. In the European Alps, the snow line appears to have risen considerably already over the past few decades (Schär et al., 1998), reducing snow reliability in many resorts. This trend will eventually push low-lying ski resorts out of business (Elsasser and Bürki, 2002; Elsasser and Messerli, 2001). 
Areas that have historically been popular among beach tourists will also be affected. According to some climate change scenarios, the extraordinary heat wave that hit Europe in the summer of 2003 may represent normal summer conditions by the end of the century (Beniston, 2004), making Mediterranean destinations intolerably hot, and giving northern destinations a more pleasant climate. Low-lying areas, in particular in developing nations, may suffer from sea level rise, or even disappear. Small island states in the Caribbean and the Pacific, many of them tourist destinations, are among the countries that are most vulnerable to climate change (Nurse and Sem, 2001; Viner and Agnew; 1999).

These small island states are also among the countries that are most dependent on tourism. For some of them, the economy-wide contribution of tourism represents more than half of total GDP (WTTC, 2004), e.g. in the Seychelles $(60 \%)$, the Maldives $(63 \%)$, Antigua ( $86 \%$ ) and Aruba $(71 \%)$. For the world as a whole, tourism's economic feedback is substantial as well. In 2004, the travel and tourism industry directly contributed $3.8 \%$ of global GDP and $3 \%$ of global employment, while the total economy-wide impacts of travel and tourism added up to an estimated $10.6 \%$ of global GDP and $8.3 \%$ of global employment (WTTC, 2004).

The lure of profits and employment in tourism makes tourist resorts and destinations attractive locations for settlement. Areas that were sparsely populated and remote before the arrival of tourism can become poles of population growth and urbanisation. This contribution of tourism to urbanisation can be found throughout the world. The Spanish archipelago of the Balearics is a clear example. Between the middle of the 19th century and the 1950s, the population of most towns and villages in the Balearics had been stable. In the 1960 s a transition took place that redirected the predominantly agricultural society towards tourism. As a result of tourism activity, immigration and urbanisation increased rapidly. The residential population of Calvià, Majorca's second town, increased from 2300 inhabitants in 1960 to 14000 in 1985 , to 29000 in 1995 and to over 40000 in 2001 (Miranda, 2001). Seasonal workers increase population size by another 110000 to some 150000 in the holiday season. Similar developments have been documented for the island of Menorca (Fullana, 2004). In 2003, almost 50 million tourist nights were spent in the Balearics, almost ninety percent by foreigners (INE, 2005).

\subsection{Scope and objectives}

Arguably, there is not much wrong with tourism as such. Among other things, it allows people to 'get away from it all', recover after periods of thard work, 
discover the world, and show their status. Some see tourism as an ethically repugnant activity that is void of spontaneity, and of genuine interest in the culture and history of the host country. These moral considerations do, however, not appear to be the main reason why people around the world look at tourism with a certain suspicion and anxiety:

Many of the major problems with tourism are rooted in scale and concentration. The first tourists that visited the Spanish coasts caused little damage; the hundreds of millions that came after them have irreversibly altered the coastal communities and landscapes. The impact of one single European eco-tourist visiting the South American rainforests is negligible; the greenhouse gas emissions produced by the many millions of intercontinental eco-travellers, on the other hand, are very significant.

Scale and concentration are interlinked and come in a range of different guises. Concentration can refer to the number of tourists or the amount of tourist activity per square kilometre or per month, i.e. the scale of tourism per unit of space or time. Concentration can also refer to the distribution of the costs and benefits from tourism over the members of a community. Scale refers to the amount of tourist activity in an absolute rather than relative sense.

Concerns about the increasing concentration and scale of tourism have contributed to the emergence of sustainable tourism as a popular concept in the tourism community at large. Approaches to sustainable tourism typically take the development of tourism as such for granted (Sharpley, 2000), and set out to increase the economic, ecological and social benefits from tourism, while reducing the pressure on ecology and society, and on the economy. Ecotourism is a well-known answer to these challenges: Itts low-density nature and focus on quality promise to improve local participation, increase local revenues, foster nature conservation, while causing little disturbance to nature and society.

Ideas and plans for sustainable development have been elaborated much more for local destinations than for the world as a whole. Important issues of scale have been largely neglected. What would be the implications if a large share of the international tourist market would embark on eco-tourism holidays? is there enough space available to do this, and would it be more sustainable from a global perspective than mass tourism in large resorts?

In addition, there has been little attention for the prospects of tourism itself in the context of broader societal developments, not only in tourist destinations, but also in source countries. What would be the implications of large price shocks, such as soaring oil prices for the scale of tourism? How will climate 
change affect tourists choice of holiday destination, and the distribution of benefits and pressures?

This thesis aims to answer some of the forgotten questions about scale and concentration. The main thrust of the thesis is future-oriented. It challenges the view implicit in most of the rare explorations of future tourism development that the societal context around tourism will remain virtually unchanged or can be forecast or predicted based on historical trends. Given the futures inherent uncertainty and tourism's complexity, this position is untenable. Predictions are of little value, in particular those pertaining to the far future.

This conclusion, however, does not detract from the value of making assessments of future developments per se. On the contrary, entrepreneurs, politicians and other decision-makers need them to base their decisions on. Contemplating a range of plausible futures allows stakeholders to develop policies and strategies so that they are prepared for many eventualities.

In this thesis, integrated scenario analysis is used to reconcile the need for assessments to the inherent uncertainty of future developments. Rather than providing one prediction, a range of plausible future worlds and their implications are explored. Scenario analysis is used to think "outside the box' of the business-as-usual developments in tourism. Simulation models and stakeholder participation are used to substantiate the logic in the scenarios.

By thinking 'outside the box', this thesis aims to answer the following central question:

- In what different ways might the determinants of tourism develop in the coming decades, and what would this imply for the global scale and distribution of tourism?

This question is split up into four sub-questions:

- Which are the main historical and current determinants of tourism, and what seasonal and geographical tourism patterns do they bring about?

- How might these patterns change over the next decades?

- What is the potential impact of climate change on tourism patterns around the world, and in the Netherlands in particular?

- What are the potential effects on tourism demand of abolishing the current tax exemptions on aviation fuel and tickets?

The last two sub-questions zoom in on two emerging issues that have the potential to significantly change the distribution (climate change) and scale (aviation taxes) of tourism in the future. 
Climate change will impact on tourism in many different ways, including changes in thermal comfort and season length, beach erosion, water shortages, and vegetation change. Structured and coordinated research into the links between tourism and climate change is of a recent date. Despite these potential impacts, the interest in the research field of climate change and tourism is still rather limited. As a result of the large uncertainties in projections of the future climate, and the perceived long-term character of climate change, the interest among tourist businesses is even lower. Nevertheless, a number of assessments of the impacts of climate change on tourism on a global (Agnew and Viner, 2001; Viner and Agnew, 1999) and national (e.g. Amelung, 2002; Amelung, 2005 for the Netherlands) scale have been published, suggesting significant impacts. In addition, an international network of researchers and practitioners has developed after dedicated conferences and workshops in Djerba (Nicholls, 2004), Milan (Viner and Amelung, 2003), Warsaw, and Genoa (Amelung and Viner, 2004). In this thesis, the implications of climate change for the tourist potential of destinations around the world are explored.

Aviation is one of the most rapidly growing sources of greenhouse gas emissions. Air traffic is increasing at 3 to $5 \%$ per year, the technological possibilities of reducing aircraft $\mathrm{CO} 2$ are limited and projected traffic growth overwhelms gains from fuel efficiency (Lee et al., 2005). An estimated $50 \%$ of air travel was for leisure-related purposed in 1996 (Gössling, 2002) and this share has probably increased since then. In spite of their relevance in terms emissions, international aviation and shipping are not covered by the Kyoto protocol. In addition, the aviation industry benefits from a range of tax exemptions, including kerosene levies, and VAT on tickets. As a result of the negative impacts of aviation, these fiscal benefits are under increasing scrutiny. This thesis explores what abolishing the fiscal advantages might imply for aviation demand.

\subsection{Outline}

The thesis is structured as follows. Chapter two introduces Integrated Assessment, the research philosophy used in this thesis, and details the methodological approaches taken in the various chapters. In chapter three, a broad overview is given of the development of tourism over the past few decades with an emphasis on the driving and inhibiting forces, and on the main impacts that are described in the tourism literature. Chapter four reports on the implications of staging cultural performances for the distribution of tourism revenues in Mombassa Old Town, Kenya. It integrates economic and anthropological concepts and insights to arrive at a deeper understanding of the 
mechanisms behind the limited share of tourism revenues 'trickling down' to the poor in many developing countries.

Chapter five presents an integrated scenario analysis for the future of global tourism. The four scenarios that are considered are based upon different assumptions about the future development of a range of key driving forces. The analysis focuses on the implications that the various scenarios might have for the spatial and temporal patterns in international tourism. Chapter six addresses the current spatial and temporal patterns of tourism-relevant climatic conditions and the changes therein from a global perspective. It assesses the current climatic attractiveness of regions in different seasons, using climatic indices specifically designed for tourism. The chapter then goes on assessing the future impact of climate change on the spatial and temporal patterns of climate suitability for tourism. Chapter seven zooms in on the impacts of climate change for tourism suitability in the Netherlands. It distinguishes between a number of different types of tourism and recreation, including beach tourism, city tourism, and amusement parks. The work contained in this chapter is part of a large Dutch research project that explored the vulnerability of several Dutch sectors to climate change (Van lerland et al., 2001). In this project, no scenarios of abrupt climate change were considered. Chapter eight investigates the historical roots of the tax exemptions in aviation, the possibilities for discarding them, and the possible effects this could have for international tourism flows. Chapter nine recapitulates the main conclusions drawn in the thesis, provides an answer to the research questions posed, and offers an outlook to future work.

\section{References}

Aguiló, E. Alegre, J. and Sard, M. (2005). "The Persistence of the Sun and Sand Tourism Model." Tourism Management, 26(2): 219-231.

Amelung, B. (2002). "Klimaat En Toerisme: Tijdige Voorbereiding of Last-Minute Aanpasising? De Gevolgen Van Klimaatverandering Voor Toerisme \& Recreatie in Een Nederlandse Context." Vrijetijdstudies, 20(2): 5-20.

Amelung. B. (2005). "Gevalgen Van Klimaatverandering Voor Recreatie En Toerisme." in: Bresser, A. H. M."Berk, M. M. Van den Born, G. J., Van Bree, L., Van Gaalen, F. W., Ligtvoet, W., Van Minnen, J. G. and Witmer, M. C. H. (eds.) Effecten Van Klimaatverandering in Nederland, MNP: Bilthoven.

Amelung, B. and Viner, D. (2004). "Climate Change, Environment and Tourism in Europe's Coastal Zones." TOURISM $52(4)$ : 384-385.

Beniston, M. (2004). "The 2003 Heat Wave in Europe: A Shape of Things to Come? An Analysis Based on Swiss Climatological Data and Model Simulations." Geophysical Research Letters, 31(2): L02202.

Busch, H. and Luberichs, J. (2001). Reisen Und Energieverbrauch, Academia Verlag: Sankt Augustin. 
Coelho, P. R, and MeClure, J. E. (1993): "Toward an Economic Theory of Fashion." Economic Inquiry, $31(4): 595-608$.

Elsasser, H. and Bürki, R. (2002). "Climate Change as a Threat to Tourism in the Alps." Climate Research, 20(3): 253-257.

Eisasser, H. and Messenti. P. (2001). "The Vulnerability of the Snow Industry in the Swiss Alps." Journal of Mountain Research and Development; 21/4), 335-339.

Fullana, A, (2004). "Evolución De La Población De Menorca a Finales De Siglo Veinte: Incidencia De La Actividad Turistica En Su Desarrollo." Paper presented at the ninth Congreso de Poblacion Espanola, 23-25 September 2004, Madrid.

GGDC (2005) "Total Economy Database, January 2005:"Groningen Growth and Development Centre and the Conference Board: Groningen.

Gossling; S. (2002). "Global Environmental Consequences of Tourism." Global Environmental Change, 12(4): 283-302.

Harremoës, P. and Turner, R. K (2001). "Methods for Integrated Assessment." Regional Environmental Change, 2(2): $57-65$.

INE (2005). "Hotel Occupancy Survey." Spanish Statistical Institute (INE).

IPCC (2001). Climate Change 2001: Synthesis Report, Cambridge University Press.; Cambridge, United Kingdom, and New York, NY, USA.

Kleemen, G., Forrest, J., Hamper, D., Rhodes, H., Smith, S., Epps, R., Lloyd, C., Rugendyke, B. and Sherval, M. (2000). A Geography of Global Interactions 2, Heinemann: Port Melbourne.

Lee, D. S. Lim, L. L. and Raper, S. C. B. (2005). "The Role of Aviation Emissions in Climate Stabilization Scenarios. Poster Presented at the Symposium Avoiding Dangerous Climate Change, Convened By the Met Office, 1-3 February 2005." Exeter.

Miller, C. M., Mcintyre, S. H. and Mantrala, M. K. (1993). "Toward Formalizing Fashion Theory." Journal of Marketing Research, 30(2): 142-157.

Miranda, M. A. (2001). "Inmigración y Cohesión Social en Calvià Mallorca." Scripta Nova: Revista Electrónica de Geografia y Ciencias Saciales, $5(94): 21$.

Nurse, L. A. and Sem, G. (2001). "Small Island States." in: McCarthy. J. J., Canziani, O. F., Leary, N. A., Dokken, D. J. and White, K. S. (eds.) Climate Change 2001: Impacts, Adaptation and Vulnerability, Cambridge University Press: Cambridge.

Prosser, R. (1994). "Societal Change and the Growth in Alternative Tourism." in: Cater, E. and Lowman, G. (eds.) Ecotourism: A Sustainable Option?, John Wiley \& Sons Ltd.: Chichester.

Rennen, W. and Martens, P. (2003). "The Globalisation Timeline." Integrated Assessment, 4(3): $137-144$.

Schär, C., Davies, T. D., Frei ${ }^{C}$. Wanner, H., Widmann, M., Wild, M. and Davies, H. C. (1998). "Current Alpine Climate." in: Cebon, P., Dahinden, U., Davies, H. C., Imboden, D. and Jaeger, C. C. (eds.) Views from the Alps, The MIT Press: Cambridge, USA, 21-72.

Sharpley, R. (2000). "Tourism and Sustainable Development: Exploring the Theroretical Divide." Journal of Sustainable Tourism, 8(1): 1-19.

Steffen, W., Sandersan, A., Tyson, P. D., Jager, J., Matson, P. A. Moore II, B., Oldfield, F., Richardson, K., Schellnhuber, H. J., Turner III, B. L. and Wasson, R. J. (2004). Global Change and the Earth System: A Planet under Pressure, Springer: New York.

UNDP (2004). "Human Development Report 2004: Cultural Liberty in Today's Diverse World." United Nations Development Programme: New York.

UNWTO (2006). "World Tourism Barometer, Volume 4. No. 1, January 2006." World Tourism Organisation: Madrid.

Urry: J. (2002). The Tourist Gaze, Sage Publications: London. 
Van lerland, E. C., De Groot, R. S., Kuikman, P. J., Martens, P. Amelung, B. Daan, N.. Huynen, M. Kramer, K., Szönyi, J., Veraart, J. A.v Verhagen, A. Van Viel, A, Van Walsum, P. E. V. and Westein, E. (2001). "Integrated Assessment of Vulnerability to Climate Change and Adaptation Options in the Netherlands." 410200 088, Dutch Nationall Research Programme on Global Air Pollution and Climate Change: Wageningen:

Viner, D. and Agnew, M. (1999). "Climate Change and its Impacts on Tourism", Report prepared for WWF-UK, Climatic Research Unit: Nonwich, UK.

WTO (2003). "Facts \& Figures." World Tourism Organisation, Madrid, Spain.

WTTC (2004). "Travel \& Tourism, Forging Ahead: Executive Summary." World Travel \& Tourism Council: London. 
$\therefore \quad \cdots$ 
Chapter 2

Methodological framework 



\subsection{Tourism: a complex system}

The phenomenon of global tourism consists of an intricate system of causeeffect chains running back and forth across spatial and temporal scales and across disciplinary boundaries. Positive feedbacks abound (see Chapter 1). As a result of these non-trivial positive feedbacks and the associated nonlinearities, the tourism system cannot be properly understood by decomposing it into its constituent parts. It is a so-called 'complex system'.

Chaos and complexity theory spurred a revolution in the natural sciences. The Newtonian paradigm, which was based on reductionism, linear relationships, negative feedback and a tendency towards equilibrium, had to be rejected as a framework of analysis for complex systems. Lorenz (1963) discovered that even simple deterministic systems could exhibit nonlinear behaviour. Infinitesimally small differences in initial conditions were found to produce hugely divergent evolutions of the system, a characteristic that became known as the 'butterfly effect". "A butterfly stirring the air today in Peking can transform storm systems next month in New York (Gleick, 1987)." Paradoxically, the same positive feedback mechanisms that cause butterfly effects, emblems of volatility, can also be responsible for inertia. Hypersensitivity to initial conditions implies path dependency, which sometimes produces a strong network of mutually reinforcing relationships that endure long after the initiating conditions have been superseded: a 'lock-in' effect (Waldrop, 1992). Nonlinearities occur in complex systems of many kinds, ranging from fluid systems to the global weather system and the economy. In many of these systems, long periods of relative stability (phases) are interrupted by bursts of turbulence (phase shifts) that mark periods of accelerated evolutionary change (Faulkner, 2001).

Many of the hardest challenges that our societies face today emanate from complex systems. Think of climate change with its causes springing from and its effects impacting on social systems, or of poverty with its close ties to health, access to natural resources, and education. Or think of tourism and mobility, closely linked as they are to culture, technology, income levels, demography, and the environment. The complexity of these systems poses a challenge to decision-makers who try to regulate or influence them. They are increasingly aware that it is of little use to examine the various pieces of the complex puzzles in isolation (Rotmans and Dowlatabadi, 1998). The individual scientific disciplines can offer only partial analyses and solutions, whereas a holistic approach is required. Policy instruments often proved ineffective because confounding factors were forgotten, and many of those that were effective had unexpected side-effects (Harremoës and Turner, 2001). The field of Integrated Assessment proposes an alternative, holistic paradigm to improve the basis for scientific policy support. 


\subsection{Integrated Assessment}

According to Gough et al. (1998), Integrated Assessment (IA) is a methodology for complexity, its strength lying in making the links and feedback mechanisms explicit that exist between natural, economic and social systems. It is an issueoriented research approach that knits together pieces of knowledge from many disciplines (Rotmans and Dowlatabadi, 1998) in order to focus holistically on the issue at hand.

A number of authors (Gough et al., 1998; Harremoës and Turner, 2001; Harris, 2002; Rotmans, 1998; Rotmans, 1999; Rotmans and Dowlatabadi, 1998; Tol and Vellinga, 1998; Weyant et al., 1996) set about scoping and defining the field of Integrated Assessment. These definitions turn out to have a number of common features. First of all, the purpose of Integrated Assessment is to support policy-making, rather than to advance knowledge for its intrinsic value. Integrated Assessment is not just another tool for policy-support, however; it addresses only complex issues, which it aims to structure. A common feature of complex issues is that they do not respect disciplinary boundaries, so that a transdisciplinary or interdisciplinary approach is required. While often rewarding in the end, the actual process of building bridges across disciplinary divides is typically very time-consuming (Rotmans and Dowlatabadi, 1998). Teams of disciplinary scientists have to get used to concepts, jargon, and discourses used in each other's disciplines. Integrated Assessment can, however, also be the work of individuals. As Harris (2002:205) puts it: "it still requires a few people to sit down and go through the mountains of literature, seeking the foundations of edifices and the outlines of new architects' plans".

In short, Integrated Assessment's constituting features are: policy-support, structuring of complex issues, and interdisciplinarity. Based on these three features, Rotmans (1998) defines Integrated Assessment as

"a structured process of dealing with complex issues, using knowledge from various scientific disciplines and/or stakeholders, such that integrated insights ane made available to decision makers:"

In his definition, Rotmans alludes to the involvement of stakeholders in integrated assessments. Input from all relevant actors is sought, including, but not limited to, the usual "legitimate speakers" (Gough et al., 1998), such as experts and policymakers. Indeed, it is commonly accepted that "a useful IA should be able to cope with a plurality of perspectives on a particular issue (Gough et al., 1998)." This requirement stems directly from an essential feature of complex systems and our understanding thereof: uncertainty. 
Lack of knowledge is one obvious source of uncertainty, but there are others. Quantum mechanics, chaos theory and complex systems theory show that even the behaviour of a system that is perfectly understood is uncertain. There are fundamental uncertainties that cannot be reduced by doing more research. Such uncertainties also persist in the bodies of knowledge of scientific disciplines, even though these disciplines have been successful in reducing the lack of knowledge in some areas by splitting problem areas up into ever-smaller compartments. The knitting-together of pieces of isolated disciplinary knowledge, which forms the basis of Integrated Assessment, multiplies the existing uncertainties, in particular because the connections and feedbacks between the disciplinary knowledge domains have often escaped scientific scrutiny. They are defined away or treated parametrically in traditional disciplinary research (Rotmans, 1998).

The omnipresence of uncertainty in the complex systems that Integrated Assessment aims to structure and assess allows for different valid views on the essence and functioning of these systems. The perspective that an individual assumes may depend on e.g. moral values, personal experience, social position and economic interest. Helping policy-makers address such complex issues requires a type of scientific practice that Funtowicz and Ravetz (1994) have called "post-normal science". This type of issue-driven science addresses problems for which facts and values are disputed, stakes are high and decisions are urgent (Ravetz, 1999). In such circumstances, the traditional mechanism for quality control, e.g. review by scientific peers, is insufficient. Funtowicz and Ravetz (1994) and Ravetz (1999) see the involvement of an 'extended peer community", consisting of all relevant stakeholders, as a superior form of quality control in the context of complex issues.

\subsection{Tourism, complexity and Integrated Assessment}

Tourism studies are commonly acknowledged as a separate research domain, which is multidisciplinary by nature. Indeed, scientists from a wide range of disciplines - including anthropology, geography, economics, demography, health sciences, sociology, ecology, psychology, environmental sciences, management studies and history - have studied aspects of tourism. The widespread awareness of tourism's multidisciplinary nature, and its notorious volatility make the phenomenon a potentially rewarding target for analysis with the tools of complexity theory. This type of analysis has, however, not yet become mainstream in tourism studies. The field of tourism research is relatively poor in concepts and theories, although relatively rich in empirical detail. A large share of the tourism literature consists of results from isolated 
case studies, based on ad-hoc methodologies, derived from individual disciplines:

Much of the scientific literature addresses the impacts of tourism, ranging from economic to social and cultural effects. The dominant perspective on these impacts is one of management. A typical scientific paper in this branch starts with a description of the current state of affairs in a destination, continues with the identification of excessive detrimental effects or insufficient favourable effects of tourism, and ends by proposing measures to guarantee a more balanced form of tourism development. This kind of studies found a structuring idea in the concept of sustainable development, which was popularised in the Brundtland report by the World Commission on Environment and Development. Typically, public authorities are called upon to assume the task of managing tourism in a sustainable way.

Over the last few years, an undercurrent has developed in tourism research, which criticises the dominant 'command-and-control' perspective in tourism research. Authors such as Faulkner (2001). Russell and Faulkner $(1999 ; 2004)$, and McKercher (1999) make a strong case for a novel approach to tourism that is based on chaos and complexity theory. They contend that tourism essentially functions in a non-linear and chaotic manner, although at macro-levels the tourism system may operate "with some semblance of order (McKercher, 1999)."

Authoritative conceptions of tourism (e.g. the ones by Pearce (1981), Mclntosh et al. (1995), and Mill and Morrison (1992)) "argue explicitly or imply strongly that:

- Tourism can be controlled;

- Disparate tourism players function in a formally, coordinated manner to form a united whole;

- Tourism is organised and that the organisation can be controlled by a top down management approach;

- Individual tourism business function to achieve a set of common, mutually agreed upon goals;

- Tourism is the sum of its constituent parts, and

- By understanding how each part works, an understanding of how tourism works as a whole will emerge (McKercher, 1999:426)."

To substantiate their argument for a chaos-inspired model of tourism. Russell and Faulkner (1999) list a number of key differences between the old paradigm of reductionism and the new paradigm of complexity (see Table 2.1). These pioneers in chaos and tourism research and the proponents of Integrated Assessment have similar mindsets. Realising that existing methodologies and 
concepts are insufficient to understand the complex system of tourism, the former group has turned to complexity theory for inspiration. In a similar vein, albeit a longer while ago, the IA community originated in response to the poorly addressed complexity of environmental issues. This latter community has succeeded in building up a toolkit of methods that can be used to inform policymaking on a broad range of complex issues. Tourism is one of them.

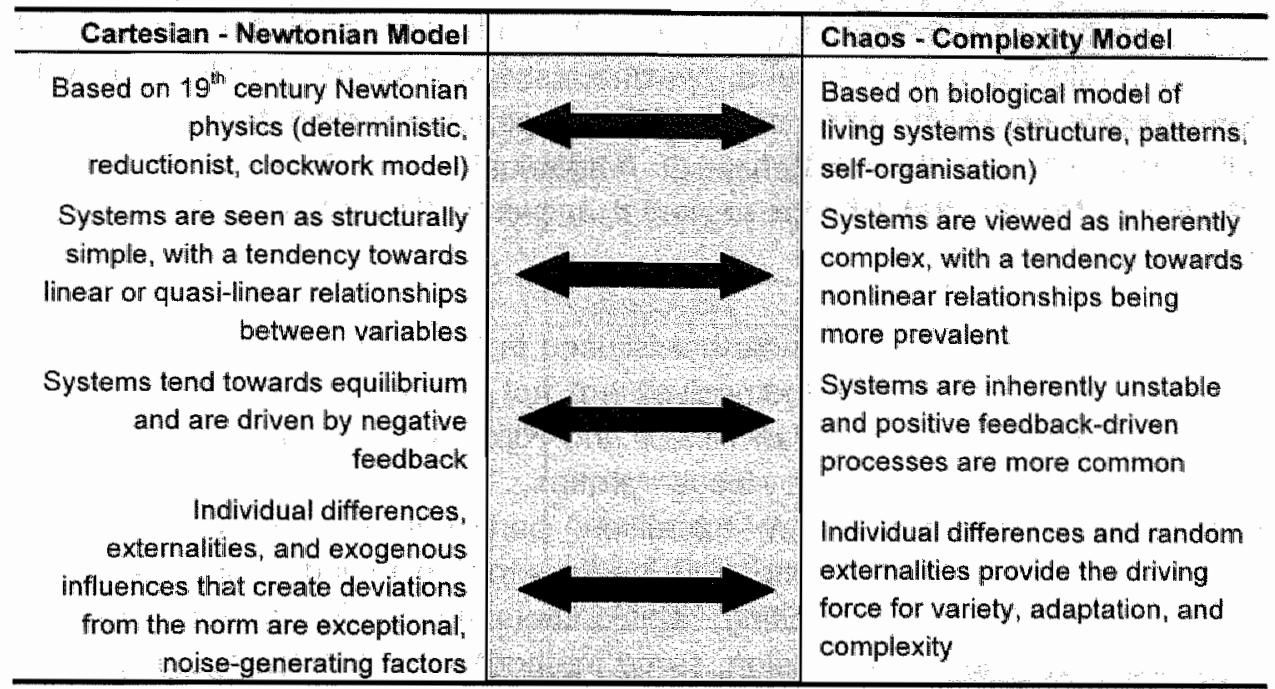

Table 2.1: The Cartesian-Newtonian versuis chaos-complexity models

Source: Russell and Faulkner (1999)

\subsection{The Integrated Assessment toolbox}

The methods that were developed and applied in the context of Integrated Assessment projects are commonly grouped together into two categories: analytical tools and participatory methods. IA requires a toolkit to combine and structure knowledge, but it also demands the interpretation, communication and discussion of this knowledge with stakeholders and policy-makers (Harremoës and Turner, 2001).

The toolkit of analytical methods consists of model analysis "scenario analysis and risk analysis. These methods are considered more mature than the participatory methods (Rotmans, 1998): they are reasonably well defined, and there is at least a workable amount of common understanding of their scope, advantages and disadvantages. Not only is there more experience with the use and application of these methods in IA contexts, they are also more widely accepted and used as legitimate scientific tools in disciplinary, 'normal' science than participatory methods. 
Particupatory methods - such as policy exercises and focus groups - are more exclusively linked to the emerging paradigm of 'postnormal science' (Funtowicz and Ravet $z$, 1994). The scientific movements of postmodernism and social constructivism have challenged the monopolistic position of science in the production of knowledge. They argue that the quality of research can be improved by involving relevant stakeholders, because these can contribute practical knowledge and experience, as well as a range of different perspectives (Van Asselt and Rijkens-Klomp, 2002). Although this more modest view of science's role has gained ground over the last few decades, it still meets with considerable opposition and hostility. Many researchers hesitate to accept the full implications of the existence of fundamental uncertainties, being that "searching for 'the truth' or for universal answers". (Rotmans, 1999) must be abandoned.

The set of participatory methods that is used in Integrated Assessment is not clear-cut, and the methods themselves are not clearly defined. Based on an extensive literature review, Van Asselt and Rijkens-Klomp (2002) distinguish eight participatory methods: focus groups, scenario analysis "scientiststakeholder workshops, policy exercises, participatory modelling, citizens' juries, consensus conferences, and participatory planning. Some of these methods constitute policy-making, while others merely inform policy-making processes. On another dimension, some methods aim at reaching consensus, while others aim at mapping out diversity. All participatory methods that have been used in Integrated Assessment - the first five in Van Asselt and RijkensKlomp' list - are aimed at informing policy-making by mapping out diversity (Van Asselt and Rijkens-Klomp, 2002).

\subsubsection{INTEGRATED ASSESSMENT MODELS}

Models were arguably the first tools that were used in integrated assessments. One of the earliest examples of such models was the one underlying the famous "Limits to growth" report to the Club of Rome by Meadows et al. (1972). In a limited number of equations, the authors tried to combine knowledge on a number of key issues such as demography, economy and resource use to explore the future of mankind's interaction with nature and the environment. Later in the 1970 s, scientists exploring the issue of acidification took a similar approach in institutes such as the International Institute for Applied Systems Analysis (IIASA) and the Dutch National Institute of Public Health and the Environment (RIVM) (Rotmans and Dowlatabadi, 1998).

Integrated Assessment models are never intended as 'truth machines' that perfectly replicate systems or predict the future. Rather, they are used for structuring information, and for exploring interactions and sensitivities. Typically, 
Integrated Assessment models draw on detailed disciplinary models. Combining such detailed models would produce models that are completely unwieldy and intractable. In addition, the level of detail and uncertainty often varies greatly between disciplinary models. As a result, the modules in Integrated Assessment models are simplified disciplinary models that are greatly reduced in size but still contain the essence of the underlying detailed models. The effort of reducing models to their bare essence is often illuminating, but also a key weakness of Integrated Assessment models. Highly abstract models often lack credibility among policy-makers and the general public. Another recurring weakness is the limited scientific foundation of the nature of the connections and feedbacks between the modules. Table 2.2 gives a summary of the strengths and weaknesses of Integrated Assessment models.

\begin{tabular}{l|l}
\hline Strengths & Weaknesses \\
\hline & Overly complex \\
Exploration of interaction and feedback & Too high level of aggregation \\
Flexible and rapid simulation tools & Lack of credibility \\
Counterintuitive results & Inadequate treatment of uncertainty \\
Tools for communication & Absence of random behaviour \\
& Limited verification, validation \\
& Inadequate knowledge, methadology \\
\hline
\end{tabular}

Table 2.2: Strengths and weaknesses of Integrated Assessment models

Source: Rotmans (1998)

\subsubsection{INTEGRATED SCENARIOS}

Scenario analysis is a well-established response to uncertainty about what the future will bring. Decision-making often depends on information about the future, e.g. future trends or policy impacts. In traditional types of scenario analyses there is considerable confidence in the predictability of the future. Based on information about the current situation and current trends, projections for the future state or development are constructed. Such projections are typically referred to as 'business as usual' (BAU) scenarios. Uncertainties, which are presumed to originate from 'noise' and lack of knowledge, are incorporated by complementing the BAU scenarios with 'high' (optimistic) and 'low' (pessimistic) scenarios. Traditionally, such projections are based on insights from one or a handful of disciplines. There are separate scenarios for phenomena such as population growth, economic growth, and technological development, which are developed without checking for consistency between them.

The complexity paradigm challenges the traditional approach of exploring the future. It rejects the notion that from information about the present, insights into future developments can be derived, in particular if these developments take 
place in the medium or distant future; remember the "butterfly effect'. In addition, the longer the time horizon, the more likely it is that gradual or abrupt discontinuity (Van Notten et al, 2005) will occur. Integrated Assessment, being an issue-centred rather than disciplinary approach, challenges the BAU-type of scenario analysis on an additional ground. It rejects the disciplinary way of making projections and proposes an integration of projections and insights into coherent integrated scenarios:

An IA-inspired definition of scenarios is provided by Van Notten (2001): "scenarios are descriptions of journeys to possible futures that reflect different perspectives on past, present and future developments with a view to anticipating the future." As the future is inherently uncertain, scenarios cannot predict; rather, they paint pictures of possible futures and explore the different outcomes associated with "what-if' questions (Greeuw et al., 2000). Scenarios are powerful tools to articulate key assumptions, blend qualitative and quantitative knowledge, identify constraints, and expand our thinking beyond the conventional (Rotmans, 1998).

Over the years, a variety of scenarios have been developed, differing in terms of subject (issue-based, area-based, institution-based), and temporal and spatial scales (Van Notten et al, 2003). Typical integrated scenarios are issuebased or area-based and employ a time horizon of a few decades. A number of spatial scopes have been used for scenario development, ranging from the local scale, to the continental and global scales. Integration of multiple scales was a key objective in recent scenario studies such as VISIONS and UNEP's GEO-3 (Van Notten et al., 2003).

\subsubsection{RISK ANALYSIS}

"Risk can be defined as the possibility that certain losses or damages occur as the result of a particular event or series of events (Rotmans, 1998)." There is a close relationship between risk and uncertainty. The notion of risk applies to situations that have several possible outcomes of which at least one is undesirable (Merkhofer, 1987). Traditional risk analysis depends on the possibility of assigning probabilities and damage values to the undesirable outcome(s). In the face of fundamental uncertainties and surprises, this type of analysis therefore loses much of its value, in particular when applied to longterm developments.

The complex systems that Integrated Assessment deals with, riddle with uncertainty. In fact, uncertainty and fundamental unpredictability are at the very heart of complexity theory and Integrated Assessment. People evaluate key uncertainties in different ways, leading to different assessments of the situation. Keeping track of all the different possibilities is a daunting if not impossible task 
for the researcher, in particular if such sensitivity analyses are carried out for several uncertainties at a time. The results are also very difficult to communicate to policy-makers. The $\mathbb{A}$ community therefore faces the challenge of dealing with uncertainty in an explicit way. while keeping the analyses manageable. Several authors (Rotmans and Van Asselt, 2001; Thompson, 1997; Van Asselt, 2000; Van Asselt and Rotmans, 2002) have turned to cultural theory (Douglas and Wildavsky, 1982; Thompson et al. 1990) for a way forward. Cultural theory distinguishes a number of archetypal perspectives on the way nature and society operate and on the preferred style of managing these systems. The archetypes are called 'individualist"; 'egalitarian', and 'hierarchist'. A person with an 'individualist' tendency believes that ecological and societal systems are very resilient to shocks; the 'egalitarian' believes that these systems are very sensitive to perturbation, while the 'hierarchist' believes that nature and society are stable within certain limits. As a result of fundamental uncertainty and lack of knowledge, none of these views can be proven true or false.

From the cultural theory, it is inferred that the way in which uncertainties are evaluated is highly correlated with the perspective taken. Taking advantage of this, the virtually endless number of combinations of uncertainty evaluations can be reduced to just a few coherent sets of such evaluations, which are grouped around the archetypal perspectives. Based on the fact that these perspectives are extreme cases, the coherent sets of uncertainty evaluations are assumed to mark the boundaries of the 'possibility space' of the system's operation. This approach to making uncertainties explicit in a structured way has been implemented in the TARGETS model (Rotmans and de Vries, 1997).

\subsubsection{PARTICIPATORY METHODS}

The five participatory methods that, according to Van Asselt and Rijkens (2002), have been used in integrated assessments are focus groups, participatory modelling, scientist-stakeholder workshops, scenario analysis, and policy exercises. They all help assessors in structuring, eliciting tacit knowledge about and identifying perspectives on the complex issue being studied, albeit in different ways. Focus Groups consist of a limited number of stakeholders who have structured, moderated discussions to elicit preferences, opinions and viewpoints. The method of Participatory Modelling takes the additional step of allowing stakeholders to explore, while they discuss, the implications of their ideas by formalising them in a model. In Scientist-Stakeholder Workshops, stakeholders aid scientific experts by discussing scientific findings and helping to identify key research priorities and to formulate a research agenda. To have stakeholders identify key issues is also a main aim of Scenario Analyses, but in this case the participants take the additional step of constructing plots for the future development of these issues. As a next step, these plots can be knitted 
together into a set of full-blown scenarios that explore a range of possible futures. In Policy Exercises, a heterogeneous group of stakeholders synthesises the complex issue at hand. Subsequently, the participants assume different roles to simulate a decision-making process in order to explore the dynamics of such a process.

\section{DECISION-MAKING IN THE FACE OF COMPLEXITY}

Decision-making in the face of complexity requires the avallability of holistic and interdisciplinary rather than reductionist and monodisciplinary knowledge. Integrated Assessment has taken up this challenge by focusing on issues (rather than disciplines or scales) and collecting and integrating all relevant knowledge pertaining to them. It acknowledges the central role of uncertainties in complex systems by treating them explicitly and by using stakeholder input in the assessment process.

However, there are additional barriers to be levelled if policy-malking is to be successful in solving complex societal problems. Like science, policy-making is highly compartmentalised, its segmentation being based on sectors rather than issues. In addition, political decision-making is often structured around "go/nogo" decisions that are difficult to reverse or adjust in a later stage. These characteristics make the current policy-making paradigm ill suited to respond to the challenges that complex problems pose to society. The issue of climate change, for example, is not exclusively (or even, not primarily) an environmental problem to be solved by the Ministry for the Environment; the issue of mobility and congestion is not just a transport problem that needs solving by the Ministry for Transportation. These issues are rooted in the very foundations of modern society and for their solution they require concerted action by the government and a host of societal actors. In the Netherlands this conclusion has triggered the emergence of a new policy-making paradigm: transition management.

Transition management postulates that solving persistent ('wicked") problems requires more than technical fixes and marginal efficiency improvements: structural changes in the system are indispensable. Such structural systemic changes, or 'transitions', can only occur as the upshot of mutually reinforcing changes in a multitude of areas within the complex system and on different scales. Rotmans et al. (2001) defines the concept of transition as "a gradual, continuous process of structural change within a society or culture." A transition is called successful if the societal system moves from one dynamic equilibrium to a structurally different one.

The origin of the transition concept lies in demography. The term 'demographic transition" refers to the change from a dynamic equilibrium of high mortality and high fertility, via a transitory situation of low mortality and high fertility, to (if 
successful) a new dynamic equilibrium of low mortality and fertility. Similar patterns of change have also occurred in other areas. Historical examples of successful transitions include the 19th century transition from wind to steam as the main provider of ships' propulsion (triggered by simultaneous changes in technology, trade systems and regulation) and the 20th century transition from steam to electricity as the main source of energy in industry (Geels and Kemp, 2000). These transitions occurred naturally and unplanned, but there are also examples of successfully planned transitions. Rotmans et al. (2001) report on a transition in the post-war period that was planned and managed by the Dutch government: the transition from oil to gas as the main fuel for domestic heating and cooking.

The Dutch example suggests that managed transitions could be the key to bringing about the structural changes that are needed to solve our societies' wicked problems. While transition management as a new policy-making paradigm provides a new perspective on complex issues, it also raises many questions. As a result of the uncertainties permeating complex systems, it is far from clear what structural changes are needed, what developments are needed to bring them about and if these developments will indeed have the intended result. Transition management is therefore based on the philosophy of adaptive management, emphasising on-going experimentation and trial-and-error, and resisting irreversibility in long-term decisions. The policy-making paradigm of transition management is reflected in its five 'golden rules' (Rotmans et al., 2001):

- Use long term thinking (at least 25 years) as the reference for short term policy making;

- Think in terms of multiple domains, multiple actors on multiple levels;

- Use learning processes as a steering mechanism (learning-by-doing and doing-by-learning);

- Invest in system innovations and system improvements;

- Keep a large number of options (wide playing field) open.

\subsection{Research approach}

The main research question that this thesis aims to address is (see Chapter 1): In what different ways might the determinants of tourism develop in the coming decades, and what would this imply for the global scale and distribution of tourism?

Structured analysis of the future of tourism is uncommon in the academic literature and elsewhere. Forecasts are available (e.g. TUI UK, 2004; WTO, $1995 ;$ 2001), but these do not reflect the complexity and uncertainties in a 
satisfactory way. Analyses of trends have been published too (e.g. Gartner and Lime, 2000), but these studies typically do not check these trends for consistency and coherency.

A major aim of this thesis is to provide structured explorations of the future of tourism by applying the tool of integrated scenario analysis. Van Notten (2005) defines scenarios as "coherent descriptions of alternative hypothetical futures that reflect different perspectives on past; present, and future developments, which can serve as a basis for action:" This definition indicates that although scenarios are hypothetical; they are not completely free-floating, connected as they are to past and present developments. The first chapters in this thesis are therefore dedicated to an overview of past and current developments of tourism and its determinants and impacts. Issues of scale and distribution (or concentration) are at the focus of attention.

Scale and concentration are of the utmost importance for understanding the (sustainability) problems that tourism has to cope with. The key issues of spatial and temporal concentration are discussed around the themes of seasonality and the destination life cycle. In the absence of a generic framework, the issue of social concentration, i.e. the distribution of advantages and disadvantages over a population, is addressed with a case study in Mombassa, Kenya. Participatory techniques were used in this case study to elicit the views and perspectives of different stakeholders on local tourism development. This case study is meant as an illustration of how a specific distributional pattern of costs and benefits of tourism development can come about under the influence of general and location-specific factors. Within the scope of this future-oriented thesis, no comparative analysis of multiple case studies was performed, so that the results from the Kenya case study cannot be generalised.

Based on the overview of past and current developments, the future of global tourism is explored. The first objective is to set the overall scope by exploring the main features of the future nature, scale and distribution of global tourism for a range of plausible scenarios. This exploration is qualitative, but the followup analyses in later chapters have quantitative elements. As a result, the anticipated scenario exploration can be characterised as an exploratory, formal and complex endeavour in the typology of Van Notten (2003). The SRES suite of scenarios, developed by the Intergovernmental Panel on Climate Change (IPCC), was found to belong to this same class of scenarios, and to qualify as a useful foundation for our explorations. The driving forces that are incorporated in the SRES scenarios are very similar to those identified for tourism in the assessment of past and current tourism trends. The analysis provides an outlook on fundamentally different futures for global tourism. Some of these futures imply a more sustainable management of tourism, which is not 
something that will come about automatically. It is argued that transition management provides a promising paradigm for initiating and developing a participatory process that can ultimately lead to more sustainable forms of tourism.

Climate change has been identified as a new and emerging determinant of tourism patterns (Hall and Higham, 2005; Nicholls, 2004; Viner and Amelung, 2003) that will have important consequences. These consequences may have many guises, but one of the main one is probably the change in the absolute and relative climatic attractiveness of source and destination countries ${ }_{i}$ as these are important determinants of current tourist flows (Mather et al, 2005). The analyses in this thesis focus on the potential impact of climate change on the climatic potential of tourist destinations around the world. To that end, the current potential is estimated and then compared to projected future potentials: The climatic potentials are represented by indices that Hatch (1988) and Mieczkowski (1985) specifically designed for this purpose. Although these indices have been criticised (e.g. De Freitas, 2005), they are the best tools that are currently available (Amelung et al., in press; Scott et al., 2004).

These indices form the basis of a spatially and temporally explicit computer model that simulates the development of the climatic potential of areas around the world. This model requires climatological input data to calculate the indices. Climatological data for the interval 1961-1990, which was used as the benchmark period, were obtained from New et al. (1999), whereas the future projections were obtained by integrating the $A 1 F, A 2, B 1$, and $B 2$ SRES scenarios with the HadCM3 general circulation model (Johns et al., 2003). These datasets consist of gridded data, so that the results could be represented as maps. This enhanced visual interpretation of the shifts in climatic potential and in the length of the holiday season.

The implications of climate change for tourism in the Netherlands were explored in the context of a project that was financed by the Dutch National Research Programme on Globall Air Pollution and Climate Change (NRP). The analyses in the NRP study used three fairly similar climate change scenarios that all projected a gradual increase of temperature of 1.5 to 2.5 degrees Celsius between 2050 and 2100 (Van lerland et al. "2001). The specificity of the case allowed for a deeper analysis that went beyond climatic potential and included projections for a range of distinct market segments for tourism and recreation in the Netherlands. The findings from the literature review were corroborated and discussed in two stakeholder workshops (Gupta et al., 2004; Van lerland et al., 2001). No comparative study of the impacts of climate change on tourism in different countries was envisaged or performed. 
The global as well as the Dutch analysis was based on scenarios of gradual climate change. The potential effects of abrupt climate change (e.g. caused by reversion of the Great Ocean Conveyer Belt) or climate extremes (e.g. heat waves) have not been considered in this thesis, despite their potential relevance. These issues have been left for future research, e.g. in the eCLATCOAST project on the vulnerability of coastal tourism that has recently started at $\mathrm{ICIS}$.

The cost of transport is a very important factor for holiday decision-makers. It is also one of the factors that are most easily influenced by policy-makers, much easier than factors such as population growth and culture. Levies on fuel and VAT on tickets is common practice in most transport sectors, but not in aviation. While historically understandable (Meijers, 2005), these exemptions face increasing criticism, in the light of aviation's rapid growth and large contribution to a range of environmental and social problems. Future abolition or reduction of the tax advantages is therefore a plausible event. Since an estimated $50 \%$ of all flights are made for leisure purposes (Gössling, 2002), this would have substantial consequences for tourism; it could even cause a discontinuity in tourism development. The fiscal treatment of aviation is therefore singled out as an issue for closer inspection.

Aggregated financial statistics on aviation in Europe are used to estimate the share of fuel costs and VAT in overall ticket prices. To get a feeling for the potential magnitude of the effects of putting an end to the tax exemptions, the effects of raising fuel levies to the lowest level of gasoline levies existing in the EU, and of introducing high VAT tariffs on tickets were considered. The effect on air travel demand was estimated by multiplying the increase in ticket prices with the estimated demand elasticity for passenger air travel (Brons et al., 2002). The analysis does not pretend to yield precise results or definitive conclusions about the effects of an introduction of levies and VAT in aviation. Its main objective is to provide an order-of-magnitude estimate of the effects of the current tax exemptions on passenger air travel demand.

\section{References}

Amelung, B. Nicholls, S. and Viner, D. (in press). "Implications of Global Climate Change for Tourism Flows and Seasonality." Journal of Travel Research.

Brons, M., Pels, E., Nijkamp, P. and Rietveld, P. (2002). "Price Elasticities of Demand for Passenger Air Travel: A Meta-Analysis." Journal of Air Transport Management, 8(3): 165-175.

De Freitas, C. R. (2005). "The Climate-Tourism Relationship and Its Relevance to Climate Change Impact Assessment." in: Hall, C. M. and Higham, J. (eds.) Tourism, Recreation and Climate Change, Channell View Publications: Cllevedon. 
Douglas, M. and Wildavsky, A. (1982). Risk and Culture. Essays on the Solection of Technical and Environmental Dangers, University of California Press: Berkley, U.S.A.

Faulkner, B. (2001). "The Future Ain't What It Used to Be." Griffith University: Gold Coast:

Funtowicz, S. and Ravetz; J. (1994) "Uncertainty, Complexity and Post-Nomal Science." Environmental Toxicology and Chemistry, 13(12): 1881-1885.

Gartner, W. C. and Lime, D. W. (eds.). (2000). Trends in Outdoor Recreation, Leisure and Tourism, CABI Publishing: Wallingford, UK.

Geels, F, and Kemp, R. (2000). "Transities Vanuit Socio-Technisch Perspectief." Universiteit Twente: Enschede.

Gleick, J. (1987). Chaos: Making a New Science, Heinemann: London.

Gössling. S. (2002). "Global Environmental Consequences of Tourism." Global Environmental Change, 12(4): 283-302.

Gough, C., Castells, N. and Funtowicz, S. (1998). "Integrated Assessment: An Emerging Methodology for Complex Issues." Enwironmental Modeling and Assessment; 3(1/2): 19-29.

Greeuw, S. C. H., van Asselt, M. B. A. Grosskurth, J., Storms, C. A. M. H., Rijkens-Klomp, N., Rothman, D. S. and Rotmans, J. (2000). "Cloudy Crystal Balls." Environmental issues series 17, European Environment Agency: Copenhagen, Denmark.

Gupta, J., Van Asselt, H., Amelung, B., Berk, M.. Buiteveld, H., Dalenoord, E., Hein, L., Huynen, M., Kuik, O. Leemans, R., Martens, P., Mulder, J., Oost, A., Schaeffer, M., Verbeek, K. and Van der Wegen, M. (2004). "Re-Evaluation of the Netherlands' Long-Term Climate Targets." Institute for Environmental Studies: Amsterdam.

Hall, C. M. and Higham, J. (2005). Tourism, Recreation and Climate Change. Channel View Publications: Clevedon, UK.

Harremoès, P. and Turner, R. K. (2001). "Methods for Integrated Assessment." Regional Environmental Change, 2(2): 57-65.

Harris, G. (2002). "Integrated Assessment and Modelling: An Essential Way of Doing Science." Environmental Modelling and Software, 17(3): 201-207.

Hatch, D. (1988). "The Distribution of World Climate Conditions." Joumal of Meteorology, 13(133): 344-349.

Johns, T. C., Gregory, J. M., Ingram, W. J., Johnson, C. E., Jones, A., Lowe, J. A., Mitchell, J. F. B., Roberts, D. L., Sexton, D. M. H., Stevenson, D. S., Tett, S. F. B. and Woodage, M. J. (2003). "Anthropogenic Climate Change for 1860 to 2100 Simulated with the Hadicm 3 Model under Updated Emissions Scenarios." Climate Dynamics(Online First, 18 Feb 2003 (DOI 10.1007/s00382-002-0296-y)

Lorenz, E. N. (1963). "Deterministic Nonperiodic Flows:" Journal of Atmospheric Sicience, 20: 130141.

Mather, S., Viner, D. and Todd, G. (2005). "Climate and Policy Changes: Their Implications for International Tourism Flows." in: Hall, M. and Higham, J. (eds.) Tourism, Recreation and Climate Change, Channel View Publications: Clevedon, UK, 63-85.

Mclntosh. R. W., Goeldner, C. R. and Ritchie, J. R. B. (1995). Tourism: Principles, Practices, Philosophies, John Wiley \& Sons: New York, USA.

McKercher, B. (1999). "A Chaos Approach to Tourism." Tourism Management, 20(4): 425-434.

Meadows, D. H., Meadows, D. I. Randers, J. and Behrens III, W. W. (1972). The Limits to Growth, Universe Books: New York.

Meijers, D. (2005). "Tax Flight: An Investigation into the Origins and Developments of the Exemption from Various Kinds of Taxation of International Aviation." International Centre for Integrative Studies: Maastricht. 
Merkhoter, M W. (1987). Decision Science and Societal Risk Management; D. Reidel: Boston.

Mieczkowski, Z. (1985). "The Tourism Climatic Index. A Method of Evaluating World Climates for Tourism:" The Canadian Geographer, 29(3): 220-233.

Mill $_{i}$ R. C. and Morrison, A. M. (1992). The Tourism System: An Introductory Text, Prentice-Hall: Englewood Cliffs, New Jersey.

New, M., Hulme, M and Jonies, P. (1999). "Representing Twentieth Century Space-Time Climate Variability. Part 1: Development of a 1961-90 Mean Monthly Terrestrial Climatology. Joumal of Climate, $12(3): 829-856$.

Nicholls, S. (2004). "Climate Change and Tourism." Annals of Tourism Research: 31(1): 238-240.

Pearce, D. (1981). Tourist Development, Longman: New York.

Ravetz, J. (1999). "What is Post-Normal Science." Futtres, 31(7): 647-653.

Rotmans, J. (1998). "Methods for IA: The Challenges and Opportunities Ahead" Enwironmental Modeling and Assessment, 3(3): 155-179.

Rotmans, J. (1999). "Integrated Assessment : A Bird's-Eye View." ICIS: Maastrichit, The Netherlands.

Rotmans, J. and de Vries, H. J. M. (eds.). (1997). Perspectives on Global Change: The Targets Approach, Cambrildge University Press: Cambridge, UK.

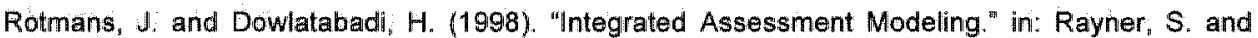
Malone, E. L. (eds.) The Tools for Policy Analysis, Battelle Press: Columbus, Ohio, 291-377.

Rotmans, d, Kemp, $R$ and Van Asselt, M. (2001). "More Evolution Than Revolution: Transition Management in Public Policy." Foresight, 3(1): 1-17.

Rotmans, J. and Van Asselt, M. B. A. (2001). "Uncertainty in Integrated Assessment Modelling: A Labyrinthic Path." Integrated Assessment, 2(2): 43-55.

Russell, R. and Faukner, B. (1999). "Movers and Shakers:" Chaos Makers in Tourism Development." Tourism Management, 20(4): 411-423.

Russell, R. and Faulkner, B. (2004). "Entrepreneurship, Chaos and the Tourism Area Lifecycle." Annals of Tourism Research, 31(3): 556-579.

Scott, D., McBoyle, G. and Schwartzentruber, M. (2004). "Climate Change and the Distribution of Climatic Resources for Tourism in North America." Climate Research, 27(2): 105-117.

Thompson, M. (1997). "Cultural Theory and Integrated Assessment." Environmental Modelling and Assessment, 2(3): 139-150.

Thompson, M. Ellis, R. and Wildavsky, A. (1990), Cultural Theory, Westview Press: Boulder, U.S.A.

Tol, R. S. J. and Vellinga, P. (1998). "The European Forum on Integrated Environmental Assessment." Envirommental Modeling and Assessment, 3(3): 181-191

TUI UK (2004). "The Thomsan Future Holiday Forum: A Future-Gazing Studly of How Holidays Are Set to Change over the Next 20 Years." TUI UK: Londan.

Van Asselt, M. B. A. (2000). Perspectives on Uncertainty and Risk: The Prima Approach to Decision Support, Kluwer: Dordrecht, The Netherlands.

Van Asselt, M. B. A. and Rijkens-Klomp, N. (2002). "A Look in the Mirror: Reflection on Participation in Integrated Assessment from a Methodological Perspective." Global Environmental Change. $12(3): 167-184$.

Van Asselt, M. B. A. and Rotmans, J. (2002). "Uncertainty in Integrated Assessment Modeling: From Positivism to Pluralism. "Climatic Change, 54(1-2): 75-105.

Van lerland, E. C., De Groot, R. S., Kuikman, P. J., Martens, P., Amelung, B., Daan, N., Huynen, M., Kramer, K., Szönyi, J., Veraart, J. A., Verhagen, A., Van Viet, A., Van Walsum, P. E. V. and Westein, E. (2001). Integrated Assessment of Vulnerability to Climate Change and 
Adaptation Options in the Netherlands." 410.200088 . Dutch National Research Programme on Global Air Pollution and Climate Change: Wageningen.

Van Notten, P. (2005). "Writing on the Wall: Scenario Development in Times of Discontinuity". Universiteil Maastricht: Maastricht.

Van Notten, P. and Rotmans, J. (2001). "The Future of Scenarios." Scenario \& Strategy Planning. $3(1): 4-8$.

Van Notten, P., Rotmans, J. and van Asselt, M. B. A. (2005). "The Future Shocks: On Discontinuity and Scenario Development." Technolagical Forecasting \& Social Change, 72(2): 175-194.

Van Notten, P., Rotmans, J., van Asselt, M. B. A. and Rothman, D. (2003). "An Updated Scenario Typology." Futures, 35: 423-443.

Viner, D. and Amelung. B. (2003). "Climate Change, the Environment and Tourism: The Interactions. Proceedings of the Esf-Lesc Worksinop." Climate change, the Environment and Tourism: The Interactions, Milan 4-6th June.

Waldrop, M. (1992). Complexity: The Emerging Science and the Edge of Order and Chaos, Simon and Schuster: London.

Weyant, J., Davidson, O., Dowlatabadi, H., Edmonds, J., Grubb, M., Parson, E. A., Richels, R., Rotmans, J., Shulkla, P. R., Tol, R. S. J., Cline, W. R. and Frankhauser, S. (1996). "Integrated Assessment of Climate Change: An Overview and Comparison of Approaches and Results." in: Bruce, J. P., Lee, H. and Haites, E. F. (eds.) Climate Change 1995: Economic and Sacial Dimensions - Contribution of Working Group lii to the Second Assessment Report of the Intergovernmental Panel on Climate Change, Cambridge University Press: Cambridge.

WTO (1995). Gobal Tourism Forecasts to the Year 2000 and Beyond, World Tourism Organisation: Madrid, Spain.

WTO (2001). Tourism 2020 Vision - Global Forecas! and Profiles of Market Segments, World Tourism Organisation: Madrid, Spain. 
PART TWO

Tourism: history and current issues 



\section{Chapter 3}

Global tourism: an overview 



\subsection{Introduction}

Tourism is commonly claimed to be the world's largest industry. Over the past half century the number of people travelling around for leisure purposes has increased tremendously. No single cause can fully explain this growth; it is rooted in a network of interacting developments (see also Chapter 1). The scale and growth rate of tourism have a wide range of implications for contemporary society. Not only does tourism generate jobs, income, and a strong incentive to protect the natural and cultural resources that it depends upon, it also contributes to resentment, inflation, and environmental pollution. A key challenge for tourism is to reconcile its positive facets with the limited carrying capacities of the natural and cultural environments, societies, and economies that it affects around the world.

The aim of this chapter is to give an overview of the contemporary history of tourism and its impacts. The chapter starts with a discussion on the essence of tourism, followed by an analysis of the major driving forces behind it. The latter half of the chapter is dedicated to a description of the impacts of tourism, and their relation to geographical and temporal concentration.

\subsection{Definitions of tourism}

The statistics on tourism, provided by the World Tourism Organisation (WTO), the World Travel and Tourism Council (WTTC), and other organisations, convey an impression of great precision. Even growth rates are often presented with a precision of one decimal or more. This level of exactness is not warranted; tourism statistics are in fact not very reliable. There are large uncertainties in measurements, and methods for data collection and aggregation differ considerably between countries.

A problem of a more fundamental nature is that the concept of tourism itself is understood in a number of different ways. This variety of perspectives reflects the complexity of tourism, and the fact that different stakeholders with an interest in tourism are have different aspirations of what they hope to achieve from it, and subsequently hold different perspectives on what it means to them (Holden, 2000). Although there is no undisputed definition of tourism, it is widely acknowledged that the term "tourism" is used to describe three concepts: the movement of people; a sector of the economy or an industry; and a broad system of interacting relationships of people, their needs to travel outside their communities and services that attempt to respond to these needs by supplying products (Chadwick, 1994). A definition that is often used is the one by Mathieson and Wall (1982): 


\begin{abstract}
"Tourism is the temporary movement of people to destinations outside their normal places of work and residence, the activities undertaken during their stay in those destinations, and the facilities created to cater to their needs."
\end{abstract}

This definition distinguishes tourism from permanent migration, but it is not clear about the precise meaning of 'temporary'. Technical, rather than conceptuall clarity is important for organisations that collect statistics. It is their interest to define tourism in a way that is unambiguous and easily measurable. The WTO and the WTTC define tourism as comprising " the activities of persons travelling to and staying in places outside their usual environment for not more than one consecutive year for leisure, business and other purposes not related to the exercise of an activity remunerated from within the place visited." This definition includes overnight visitors as well as same-day visitors, and international as well as domestic visitors. In addition, it covers a whole range of purposes, ranging from leisure and visiting friends and relatives, to business activities, health treatment, and pilgrimage.

The conceptions of tourism discussed above do not match popular understanding of the phenomenon, which relates tourism exclusively to multiday trips for leisure purposes. The share of business travel in total tourism is unclear. France (1997) estimates this share to be between two-thirds and threequarters, but warns that it differs significantly between regions. Regions differ even more in terms of their proportions of domestic and international tourism. Statistics for international tourism are readily available, whereas they are hard to find for domestic tourism. As a result, international tourism receives most attention, even though the scale of domestic tourism is considerably greater. Worldwide, it generates more employment, business opportunities and sales taxes than inbound tourism (WTO, 1998).

For this thesis, both international and domestic tourism are relevant. Whereas the chapters on tourism in Kenya (Chapter 4) and aviation (Chapter 8) specifically address international tourism, the chapter on the effects of climate change on region's tourism potential (Chapter 5) has a more general scope, while the chapter on the impact of climate change on Dutch tourism (Chapter 6) focuses on domestic issues. The aim of this chapter therefore is to provide an overview of the driving forces behind and impacts of contemporary tourism in general. 


\subsection{The scale of tourism}

From 1960 to 2005 , the number of international tourist arrivals increased by over one thousand percent (see Figure 3.1 ), while receipts from tourism grew even faster. Periods of stagnation, caused by oil crises, economic slums and terrorist attacks, are typically followed by periods of rapid growth that bring the number of international arrivals back to its long-term growth curve. In 2004, the travel and tourism industry directly contributed $3.8 \%$ of global GDP and $3 \%$ of global employment, while the total economy-wide impacts of travel and tourism added up to an estimated $10.6 \%$ of global GDP and $8.3 \%$ of global employment (WTTC, 2004).

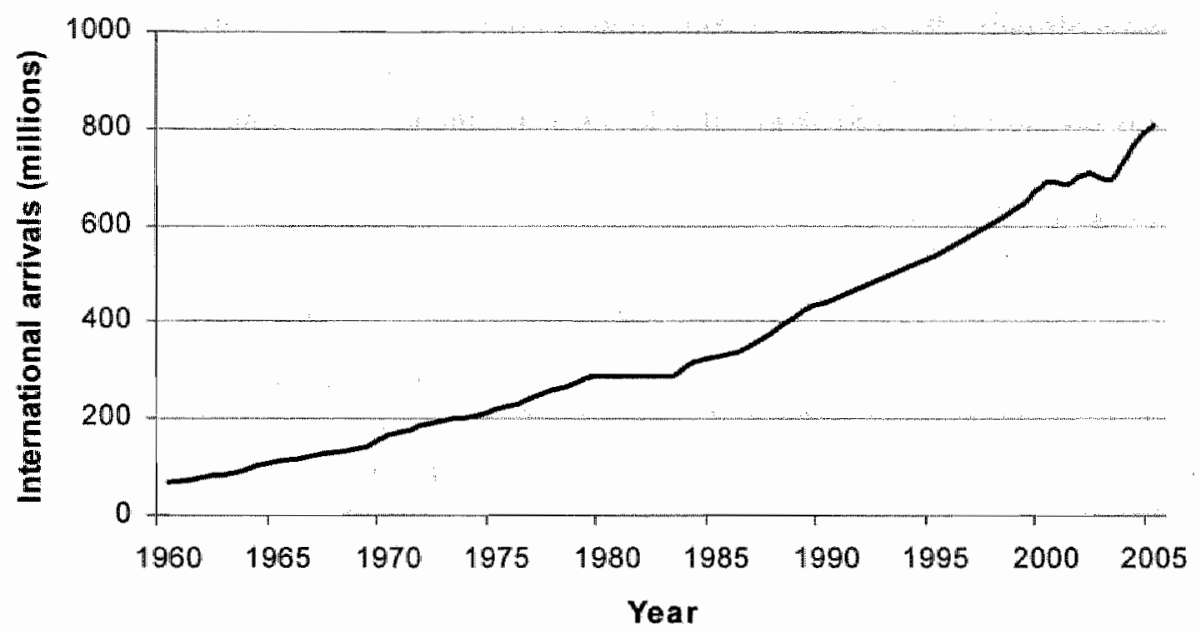

Figure 3.1: International tourist arrivals between 1960 and 2005

Source: World Tourism Organisation

International tourism is distributed very unequally across the world. Most of it takes place in, and is controlled by, the developed countries. This is illustrated by the ratio for outbound tourism, indicating the 'democratisation' of tourism, which is about 100 times higher in Europe than in southern Asia and about 10 times higher than in Africa. The European ratio for inbound tourism, indicating the maturity of a destination, is around 90 and 15 times higher than the ratios of South Asia and Africa, respectively (WTO, 1997).

Most international tourism is based in tourist resorts in coastal zones. The majority of such resorts are found around the Mediterranean Sea, in the Caribbean region, and allong the American coasts. As a result tourism is not only distributed unequally at the global level, but also at the level of world regions and even nations. 


\subsection{Driving forces}

Tourism development results from the market dynamics of supply and demand factors. Seen from a long-term perspective, demand factors dominate supply factors, because tourism is in essence a discretionary purchase (Burns and Holden, 1995), le. a luxury good. Rather than determining the size of the market, supply factors play a crucial role in allocating demand over the many holiday destinations.

Essentially, the issue of the driving forces behind tourism demand deals with a classic question in tourism studies: why do people travel? Some authors have addressed this question from an individual perspective, pointing out that the number of people that have enough time and money to satisfy their (latent) desire to travel has grown significantly. Others have turned to sociology for explanations, claiming that urbanisation and industrialisation have led to an explicit division between work and leisure, resulting in a higher propensity to travel. Sociological research has also stressed the relevance of imitation and "keeping up with the Jones" effects. A third school of thought explains tourism from developments on an even wider scale, pointing to innovations in transport and communication technologies, and to geopolitical changes.

Each of these factors is relevant, but they are all of a very different kind, which makes it difficult to integrate them into a coherent framework. Huynen et al. (2005) faced a similar problem in their search for the determinants of human health. They came up with a multi-level framework for population health, consisting of proximal, distal and contextual determinants of human health. The difference between these determinants is their position in the causal chain. Proximal factors have the most direct impact on human health, whereas distal factors operate through intermediary factors, and contextual determinants reflect the overall macro-level conditions. In addition to the multi-level approach, Huynen et al. (2005) propose to use a multi-domain approach, dividing the health determinants into four groups: institutional, economic, socio-cultural, and environmental factors. The framework has proved to be a useful platform for further analysis, despite occasional ambiguities when allocating determinants to specific categories.

As an object of study, tourism is very different from health, but they share the crucial role of multi-causality. With a few adjustments, the framework developed by Huynen et al. is applicable to tourism. The natural basic unit of analysis in tourism studies is the individual tourist, or tourist group. Tourism can be interpreted as the emerging effect of the decisions made by many millions of tourists. Normally, families are considered to be the basic unit of decisionmaking in tourism, but there is a range of alternative configurations, such as 
singles, groups of friends, and extended families. Each group of decision makers is confronted with its own specific set of goals, beliefs, and attitudes, resources and constraints, which are treated here as the proximal determinants.

Distal determinants exert most of their influence on the decision-making processes in an indirect way by affecting the proximal determinants. Peer groups, travel agencies, the media, the weather and other actors and factors influence the decision-makers' goals, beliefs and attitudes. Their resources and constraints are affected by factors such as the situation on relevant segments of the labour market, and institutionalised holiday periods in the relevant sectors. These distal determinants thus relate to the immediate economic, cultural and social contexts of the decision-makers. In a transitive way, they relate to the "normal places of work and residence" that the WTO definition of tourism refers to. The contextual determinants belong to the world outside the specific 'environmental bubble' of the decision-makers. They include the Zeitgeist, i.e. the intellectual and cultural climate of the era, but also the broader technological, economic, ecological and geopolitical contexts.

The framework presented above is used to structure the list of determinants that have been proposed as explanatory variables for the development of tourism since the end of the Second World War. The domains are arranged in a slightly different way than in Huynen et al. (2005), to reflect the special features of tourism. Demography, economy, institutions \& politics, environment, culture, and technology are distinguished as separate categories (based on WTO, 1995) and discussed below. In reality, these categories of factors are of course highly interlinked and interdependent.

\subsubsection{DEMOGRAPHY}

Population growth is one of the main determinants of tourism growth at the contextual level, simply because larger populations harbour more potential tourists. World population has increased to an estimated 6.4 billion people in 2004. There has been a gradual slowing down of population growth over the last 40 years, from aver $2.2 \%$ in 1963 to $1.2 \%$ in 2003 (U.S. Census Bureau), but differences between countries remain large. In many of the developed countries in the world, the population is ageing, because of steadily decreasing birth rates and increasing longevity.

Today, almost half the world population lives in urban areas. In the high-income countries of the OECD this share is $80 \%$, up from $70 \%$ in 1975 (UNDP, 2004). This share is lower in developing countries, but they are catching up rapidly. The level of urbanisation is crucial for the development of tourism, because travel propensity in large cities is known to be considerably higher than in rural areas (Alegre and Pou, 2004). Unlike farmers, urban dwellers are not tied to the 
land. They work in urban industries that rely on an ongoing division of labour and specialisation : for their development and survival: The increasing specialisation requires substantial co-ordination and harmonisation between the actors involved in it. This standardisation creates a difference between labour time and leisure time that is much more pronounced than in traditional agricultural societies (Kleeman et al, 2000).

Changes in the population structure affect the setting in which tourism-rellated decisions are made. The age structure of a population, for example, affects its average household size. Households are becoming smaller in the whole western world. In the European Union the average household size has decreased from 2.8 in 1981 to 2.4 in 2003 (Eurostat). In addition, the travel experiences that people pursue differ between the various stages in life, as do their resources and physical abilities. In the western world, the income position and health of pensioners have improved over the past decades, and in general, the elderly face less severe time constraints than the working-age population. In the European Union, the share of the population aged 65 years or older $(15 \%)$ accounted for $19 \%$ of all tourist trips made in 2000 . Travel by elderly is going through a phase of rapid growth. Between 1997 and 2000, the number of elderly travellers increased by $23 \%$ while their total numbers increased by less than $3 \%$ in the European countries (OECD, 2002). Specific market niches have developed to cater for the elderly travellers.

\subsubsection{CULTURE}

Tourism is closely linked to the dominant culture in the western world, which is characterised by individualisation, consumerism, and hedonism (Burns and Holden "1995). People have become increasingly critical about the quality of products and services, in particular during their holidays. Having satisfied more basic needs such as food and shelter, people can afford to spend more of their time and energy on needs that are higher in the hierarchy (see Maslow, 1954; Max-Neef, 1992), such as ego needs and self-actualisation needs.

These individualist tendencies have not rid tourism of its social context, however. Apart from being a compensation for a busy life, holidaymaking has evolved into a status symbol and an important element of life style. In essence, tourism is a fashion industry (Prosser, 1994). Most of society identifies fashion primarily with the field of costume and adornment. However, fashion theorists emphasise that fashion operates in many diverse areas of group life (Miller et al., 1993). According to Coelho and McClure (1993), fashion signals social rank and status. To be an effective signal, the fashion good must be more costly or more difficult to obtain for those who do not possess the status than for those who do. And to remain an effective signal, fashion must change. These 
dynamics operate in specific peer communities, making them typical distal determinants of tourist demand.

In a minority of communities, there has been a movement away from hedonistic mass tourism towards more conscious and responsible tourism. Demand for more active types of holidaymaking is growing, but the market share of these kinds of activities is still limited. The same holds for the market segments of other alternative forms of tourism, such as nature-based or eco-tourism. Although there are many claims of emergent green consumerism, critics argue that stated environmental concern is rarely translated into consistently 'green' consumer behaviour. According to them, it is unlikely that there exists a widespread propensity amongst tourists to adopt a new, sustainable tourism lifestyle (Sharpley, 2000).

Gender emancipation is another macro-trend. Over the last half a century, many countries have witnessed a rise in the percentage of women in the total workforce and an increase in the age at which women give birth. As a result of these developments at the contextual level, current generations of women are part of, as well as influenced by more extensive and very different networks and communities than generations of the past. Evidently, the increased participation of women has also improved their financial position and their ability to influence holiday decisions.

\subsubsection{ECONOMY}

The macro-economic climate affects the overall amount of discretionary income that is available for tourism, and the tourism-related norms in peer communities. World economic growth has oscillated around $3 \%$ per annum since 1980 . East Asia and South Asia have been performing much better, with growth rates of around $7 \%$ per year, while Latin America, Africa and Eastern Europe were doing worse. The high-income countries were realising growth rates around the global mean. In the EU-15 the average annual increases in income per capita have oscillated around $1,5 \%$ over the past decade.

Participation in tourism requires a certain minimum level of purchasing power. Tourism is a luxury good, and the propensity to spend income on luxury goods typically increases with income, while the share of income spent on basic goods such as food and heating decreases. As a result, income distribution matters. The large differences in income levels between the North and the South can account for much of the differences in tourist participation. In the low-income countries, tourism for leisure purposes is rare and an exclusive activity for the upper class. In 1995, anly four per thousand inhabitants of South Asia, consisting of countries such as India, Bangladesh and Iran, engaged in 
international tourism (WTO; 1997). In these countries, a relatively large share of tourism typically consists of business trips.

The propensity to spend money on tourism activities increases with income only after a certain income threshold is passed. Countries with sufficiently egalitarian income distribution can experience dramatic increases in tourist activities once this threshold has been reached. This phenomenon has been apparent in some of the newly industrialised countries since the beginning of the 1990s. According to the South Korean tourism agency, "a massive growth in outbound Korean travel was seen in the late 1980 s, a trend which was greatly stimulated by economic factors (Korea Ministry of Culture and Sports, 1995)." Between 1987 and 1995, the number of international tourists from South Korea rose more than sevenfold, from .5 million to 3.5 million, and they more than doubled again since then to more than 10 million in 2005 (KNTO, 2006).

There are natural boundaries to the growth of participation in tourism, however. Populations are limited, and so is the maximum number of trips you can take per year. In most developed countries, growth rates are levelling off as the tourism market is saturated, and the transition towards the leisure society is completed. Growth rates of outbound tourism in Europe have been below world average for some time, both in absolute terms as in per capita terms (WTO, 2002).

Purchasing power not only depends on income, but also on price structures. As a result of technological developments and liberalisation, the cost of transport has decreased in relative terms, which had a stimulating effect on tourism. The downward trend in transport costs has been punctuated by fluctuations in the oil price.

\subsubsection{TECHNOLOGY}

Technological developments have not only reduced the cost of travelling; they also opened up whole new opportunities for tourism. The invention and further development of the jet aircraft and high-speed trains have drastically reduced travel times and increased tourists" radius of action.

Technological advances in information and communication technologies have changed the pattern of distal determinants. More and more travellers are able to organise their own journeys via the Internet, bypassing the traditional travel agent (Lewis et al., 1998). Online services, such as the sale of paperless etickets, are rapidly developing, and this trend is expected to continue over the coming years (Marcussen, 2003). 


\subsubsection{ENVIRONMENT}

The environment can be regarded as tourism's resource base (Cater, 1987). Nevertheless, environmental developments have played no major role in the development of the global volume of tourist activities. This is not to say that the environment is unimportant for tourism. On the contrary, nature and climate are important determinants of tourist flows. Their influence on the distribution of tourism is, however, much more important, than their impact on the overall size of the tourism market.

A large proportion of leisure travel is undertaken based in part on the expectation of (more) pleasant climatic conditions. According to Perry (1993), 70 to 80 percent of UK holidaymakers cite better climate abroad as the primary reason for their trip. Pleasant weather is an important condition for many types of tourism, even though it is not always a goal in itself. Already in ancient Rome, the rich used to regularly leave their city in summer, when temperatures soared and pollution was large. In addition, they made trips aimed at improving their health, for example to hot water springs to which they attributed healing properties (Kevan, 1993). The city-dwellers of today still escape from their hectic and unhealthy environment to seek weather conditions that they consider healthy or comfortable, for example in warm and sunny areas. "Sunlust" (Gray, 1970) motivates millions of tourists around the world. Climate factors are among the main determinants of seasonality in tourism, one of the most problematic yet least understood features of the tourism industry (Higham and Hinch, 2002; Jang, 2004).

Over the last few decades, the interest in nature-based tourism has steadily increased, although it remains a relatively small niche-market. One of the countries that has specialised in nature-based tourism is Costa Rica. The majority of its visitors mention the country's natural beauty and protected natural areas as its main attractions. As it turns out, however, tourists spend far more time on the Costa Rican beaches than in its natural areas (Amelung, 1997). A feature that may be more important than nature per se is landscape. For Germans, it ranks first on the list of important characteristics of holiday destinations (Lohmann and Kaim, 1999).

\subsubsection{INSTITUTIONS AND POLITICS}

Institutional and political developments have been crucially important for the development of tourism around the world. At a contextual level, globalisation and trade liberalisation have made international travelling much easier. The establishment, integration and expansion of the European Union have removed time-consuming border controls between many countries. Cross-border tourist 
activities in Europe received an additional boost by the introduction of the euro as the joint currency.

Security is a major contextual influence on tourism too. Socially or politically unstable countries are unpopular tourist destination. The Middle East provides a good example of this phenomenon. Whereas tourism development in Europe, East Asia and the Americas is fairly steady, tourism development in the Middle East fluctuates considerably over time, partly as a result of the ongoing political instability in the region. Immediately after the Gulf War in 1990-91, the Middle East experienced a much larger decrease in tourist arrivals and receipts than the world as a whole (Cooper and Jackson, 1996). The terrorist attacks on the twin towers in New York caused a major blow to the tourist industry worldwide by suppressing demand for a number of years (see Figure 3.1).

Institutional determinants at a distal level refer to the social practices of society. They include the introduction of paid holidays and other special regulations to provide holiday opportunities, as well as the timing of religious (e.g." Christmas and Easter), school, agricultural and industrial festivals and holidays (Hinch and Jackson, 2000). This timing of festivals and holidays is very important, as it is one of the main determinants of seasonality in tourism, together with climatic factors. The original economic motivation of the long summer holiday was to allow children to help with agricultural chores on the family farm in the busy summer season during which weather conditions were most amenable (Butler, 1994). This reason has today lost its significance in many countries, yet the tradition lives on, placing a substantial constraint on family vacation planning.

Figure 3.2 provides an overview of the main proximal, distal and contextual determinants of tourist demand.

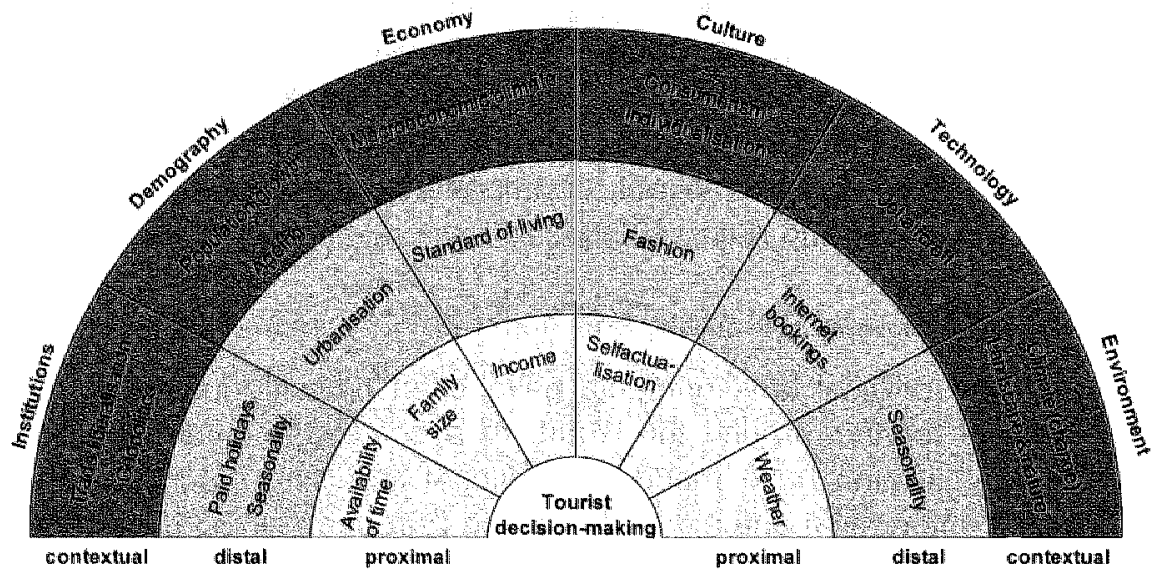

Figure 3.2: Determinants of tourist demand

Source: Adlapted from Huynen (2005) 


\subsection{Impacts}

The increase in the magnitude of global tourism has substantial implications for global society. A wide literature is available on the impacts of tourism, ranging from economic to ecological, from local to global, and from short-term to longterm effects. The aim of this section is to provide a broad overview of the impact categories, rather than an exhaustive review of the literature. To structure the overview, the impacts of tourism are discussed in three groups: economic, ecological, and socio-cultural.

\subsubsection{ECONOMIC IMPACTS}

Pearce (1981) distinguishes six categories of economic impacts:

1. Contribution to balance of payments;

2. Regional development;

3. Diversification of the economy;

4. Income;

5. State revenue (taxes);

6. Employment opportunities.

For many regions around the world, tourism provides a welcome opportunity for development. It can bring prosperity to areas that have few other opportunities for development, and can make economies that are dominated by one sector less sensitive to shocks by providing diversification. Many people find a job in tourism. Holloway (1989) and France (1997) even see these employment effects as the main contribution of tourism to the generation of national income. Local people are able to earn their wages and salaries in the tourism industry, either by providing tourist accommodation or by doing business with tourists, like being a tour guide or a food supplier. The actual number of jobs depends on many things, such as the labour intensity of the tourism industry.

The generation of income is not the only financial benefit of tourism. The economic activity also generates additional revenues for the public authorities in the form of taxes. In addition, the money that incoming tourists spend is registered as export revenue, and may be used to pay for imported goods.

As a result of these alluring prospects, many governments, communities and other stakeholders support tourism development in their regions. Everybody wants to get a piece of the global tourism action. Many of the most appealing economic statistics on tourism are, however, calculated in gross terms. Net economic tourism benefits for individual destinations are not so easily calculated. 
First of all, not all tourism expenditure flows to the holiday destination. On the contrary, many tourists are package holidaymakers, who pay for their vacation in their home country. Most international tour operators and transport companies are based in the metropolitan areas of the western world. A large share of the money that is spent on holidays to destinations in developing countries therefore never reaches the host regions. Secondly, a certain part of the initial spending by tourists tends to leak away from the destination area. The tourist industry spends its revenues on inputs (consumption) and on the payment of the production factors, labour (wages), capital (interest) and entrepreneurship (profits).

The extra consumption expenditures from buying inputs and from spending production factor income can be directed towards imported products or locally produced products. A large percentage spent on imports means a large import leakage, influencing the balance of payments. In many cases, the local community is able to meet the food and labour demands of the tourist industry as long as it remains small (Brown, 1998). Yet, as the tourism industry is growing bigger, the destination country cannot keep up with tourism development. It has to import products from other countries, thus creating an income leakage. The extent to which the local community is able to meet the requirements of the tourist industry does not only depend on size, but also on qualitative elements. In general, the larger the difference in sophistication between tourist demands and local produce, the higher the share of imports. The level of sophistication of tourist demand often changes as the destination matures.

Another potential leakage is the repatriation of income and profits to the home countries of tourist companies and their staff. The size of this leakage depends on the involvement of foreigners and foreign companies. In some develloping countries, western employees hold the more favourable and better-paid jobs in tourism (Brown, 1998), so that a significant share of income leaks away to their home countries. The level of foreign influence is typically related to a destination's stage in its life cycle (Butler, 1980). As destinations become more popular, they need large amounts of money to invest in further development. Often, investors from outside the area are needed to supply the necessary capital.

The net income from tourism is reflected in the tourism income multiplier. The income that people in a destination earn from tourism may be spent on local products, the income from which may in turn be spent on other local services or products, and so on. The multiplier thus denotes the cumulative effect of the initial tourist expenditure going through various spending cycles. The tourism income multiplier differs greatly between countries. For example, the island 
Mauritius has net foreign exchange earnings of only 10 percent, compared to 80 to 90 percent in countries like Tunisia or Kenya. A possible reason for this difference is the fact that Tunisia and Kenya only need to import luxury goods to meet tourist demands, while Mauritius is almost totally dependent on imports (Baaijens et al., 1998).

In cases where the tourist industry is relatively large compared to the local economy, tourism may lead to inflation and other effects of crowding. Tourism increases demand for all kinds of consumer products and services. The higher price level that results may have detrimental consequences for the local population, in particular for those who are not involved in the tourist industry.

Tourism also competes with other sectors for resources and production factors such as labour. People that were previously employed in other sectors such as agriculture may find a jab in the tourist industry. Tourism may thus develop at the expense of other economic sectors such as agriculture. In some cases, however, synergies may be found. Employment in tourism is usually characterised by strong seasonal cycles. If the high season in tourism coincides with the peak season in another industry, tourism development may be beneficial for both sectors.

Crowding out effects occur not only on the labour market, but on other markets for production factors as well. Competition for financial, human and natural capital increases, regularly resulting in a rise of real estate prices and shortages of local investment capital. In some areas, there is fierce competition between the tourist industry and other sectors for the scarce water resources. Tourists typically use much more water than the local population (Gössling, 2002) and peak water demand in tourism often occurs in the driest periods, when agriculture requires large amounts of water for irrigation.

\subsubsection{ENVIRONMENTAL IMPACTS}

The environment plays a vital role in the tourism industry. Climate, landscape and nature are among the main attractors in tourism. At the same time, the environment is under increasing pressure from tourism. Tourist activities cause emissions to air and water; and affect land use and biodiversity. Not all is bad, however, as tourism also contributes to the protection of natural areas.

Transport is a major source of emissions to the atmosphere. This transport includes the movement of tourists from their countries of origin to their destination countries. As tourists cover larger and larger distances and make increasing use of aircraft, emissions from tourism increase rapidly (Gössling, 2002). Tourism involves other types of transport as well, such as the movement 
of tourists inside the destination country and the transport of goods needed to support the tourists.

Clearly, transport is not the only source of emissions. The heating of accommodations and swimming pools and the use of snow machines are other examples of the consumption of significant amounts of energy, albeit much smaller than those used for transport. From a global point of view, the most important consequence of these emissions may be their contribution to global warming. On a regional level, the emissions may cause of smog and acidification:

Arguably, the main impact that tourism has on water resources is sewage. First of all, sewage disposal causes water pollution through the usage of chlorinebased cleaning agents, which threaten marine life. In the second place, in many tourism destinations sewage systems are malfunctioning, resulting in emissions of untreated sewage water to the environment. Often, sewage problems occur when tourism flows grow faster than the underlying supportive infrastructure, including sewage systems.

Emissions of sewage induce eutrophication, which poses a threat to coral reefs, and can induce excessive growth of algae. Algae bloom has occurred in many important tourism areas, including the coastal areas around the Adriatic Sea. In most of these regions, water quality is now constantly monitored, largely because of its importance for tourism. Some other direct emissions to the aquatic environment are related to special types of tourism, such as boating. Oil leakage can have severe impacts on water quality.

Tourism affects biodiversity at various levels. It has an impact on the variety of genes per species; the variety of species per ecosystem; and the global variety of ecosystems, which are the three levels of biodiversity discerned by Rotmans et al. (2001). At the level of species, tourism impacts biodiversity by hunting and fishing and by buying biotic souvenirs, e.g. products made of ivory or cracodile skin. In addition, the mere presence of tourist, as well as the noise they produce can disturb animal life, and hinder their breeding and mating rituals.

Tourism changes ecological processes, modifying the species variety of an ecosystem. Pollution is one of the ways through which this occurs. Eutrophication, for example, favours the development of some species (algae), while being detrimental to most other species, such as coral reefs. Soil trampling is another impact of tourism on ecosystem variety. Compact soils have a less abundant bacterial life and hold smaller amounts of air and water. This makes them less favourable for certain plants, and more prone to erosion. The construction of tourism-related infrastructure and facilities contributes to the 
fragmentation and destruction of habitats. Sometimes entire ecosystems are wiped away by tourism. The construction of new hotels near the seacoast, for example, can destroy transitional ecosystems between land and sea. Coral reefs are often used as cheap and convenient materials for construction activities.

Tourism has often been hailed for helping to protect natural areas that otherwise would have been lost to logging and agriculture, or to the construction of residential areas. The entrance fees that tourists pay to visit natural areas can be used for better maintenance and protection, as in the example of the privately-owned Monteverde reserve in Costa Rica (Aylward et al., 1996). The large value that nature doubtlessly represents for tourism is often not easily converted into cash for the local population, however. Most of the nature values that have been calculated are hypothetical willingness-to-pay figures, which are no match for the hard cash that people can make out of selling wood or other products from the natural area, or clearing it for agricultural purposes.

\subsubsection{SOCIAL IMPACTS}

Tourism affects tourists, hosts and host-guest relationships (Mathieson and

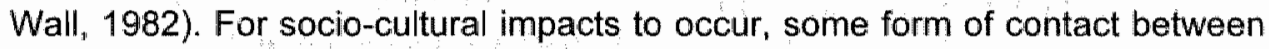
hosts and guests has to be established. Contact occurs: when tourists buy goods and services; when hosts and tourists share a facility; and when tourists and hosts meet for cultural exchange. Besides these more or less formalised forms of contact, interaction occurs through the mere physical presence of tourists.

Host-guest relationships have a number of special features, in particular in the case of mass tourism (UNESCO, 1976). To start with, they are of a transitory nature. From a guest perspective, this makes the relationship intense, spontaneous and fascinating, while for the host the relationship belongs to the routines of his professional life. The other side of the coin is that the hedonistic behaviour of many holidaymakers may give the host a wrong idea of their actual wealth and status. The apparent wealth of the guest may provide the host with a justification for exploitative behaviour. Finally, there are spatial and temporal barriers to contact. Tourist resorts and facilities are often separated physically from the living environment of the local population. When venturing outside these enclaves, mass tourists typically have a busy schedule of visiting sights, which leaves little time for in-depth communication between hosts and guests.

Although no generally accepted classification of social impacts exists in the literature, the following seven categories recur frequently (see Pearce (1981) and France (1997)): 
1. Modification of consumption patterns, and the "demonstration effect"

2. Impact on population structure

3. Transformation of forms and types of occupation

4. Congestion

5. Transformation of values

6. Health problems

7. Neo-colonialism

Tourists convey an image of success and wealth through their spending patterns and hedonic lifestyles. The host population may be tempted to try and attain the same level of apparent success by imitating the tourists' behaviour. This is called the demonstration effect. The significance of this effect is positively correlated with the cultural and economic distances between host and guest. Frustration may result, if the local population cannot afford the tourists' apparent lifestyle and standard of living. Ironically, tourists are usually just as unable to sustain their hedonistic holiday lifestyle for extensive periods of time.

In many successful destinations, tourism instigates population growth (Kent et al., 2002), often through immigration. People, usually young adults, from other areas are lured to the tourist destination by the promise of well-paid jobs. In some cases, the native population feels threatened by the competition from the newcomers, or by their impact on social networks. The risk of social desintegration is increased by the seasonal nature of tourism. During the high season, employment opportunities are far greater than during the low season. Workers flow in and out of the destination together with the tourists, hindering the development of a sense of community.

Not only does tourism generate extra jobs, it also gives rise to different types of employment. Usually, tourism not only attracts employees from the ranks of the unemployed but also from other sectors of the economy. In addition, tourism may draw some previously unremunerated activities, such as cleaning and washing, into the formal economy. These new job opportunities can provide financial independence to people that used to be dependent on others. These qualitative and quantitative changes in employment may upset the local balance of power.

The presence of tourists and migrant workers regularly causes problems of congestion. In particular in booming destinations or in destinations that are characterised by marked seasonality, locally available resources may be insufficient to meet aggregate demand. Congestion problems are not limited to the use of roads; they can also occur in relation to inadequate water supply, or scarcity on the real estate market. 
Tourism is often connected to immoral behaviour. An increase in tourism regularly goes hand in hand with increasing (or more overt) prostitution; gambling and crime. Holidaymakers feel less restricted by the moral code they face at home, and more freely indulge in hedonistic behaviour (Mathieson and Wall, 1982). Even though in most cases tourism does not cause the start of these activities, but it does create suitable locations and environments for them to flourish.

Tourism has become a significant factor in spreading disease. By moving around the world tourists spread diseases such as AIDS, cholera or malaria (Gössling, 2002). Tourists are relatively vulnerable to disease because they are often not used to local food and drinks, and unaware of local do's and don'ts. In addition, tourist resorts often accommodate large numbers of tourists, which increases the risk of infection.

Tourism is sometimes accused of being a neo-colonialist industry. It is directed from the large metropolitan areas in the Western world, leaving the rest of the world without much control and in a dependent situation. Neo-colonialism can give local people a feeling of frustration and inferiority. In the case of tourism, neo-colonialism is closely related to the share of profits and wages that are repatriated by international companies that are based in western countries.

\subsubsection{CULTURAL IMPACTS}

Culture can be divided into material and non-material elements. In turn, nonmaterial culture can be divided into habits and customs, and non-material art forms.

The forms of material culture that are most important for tourism are handicrafts and architecture. Tourism often leads to the commercialisation of art forms and especially handicrafts. Artefacts with cultural or religious meaning are popular among tourists as souvenirs. As more and more tourists visit a destination, souvenir production is increased, often leading to mass production. In the process, the cultural artefacts may lose their cultural meaning.

On the other hand, tourism may also stimulate a renewed attention for old cultural traditions and art forms, often combined with insights from other parts of the world. According to Mathieson and Wall (1982) this has been the case in the United States where Pueblo Indians combined Indian and Western techniques to create new forms of art. This development could not have taken place without the financial stimulus of tourism.

Possibly, both observations belong to the same process (Mathieson and Wall, 1982). First the traditional artistic designs and art and crave forms disappear, 
particularly those with deep religious and mythical affiliations. This meaningful art is subsequently replaced by degenerate, unsophisticated replacements that are mass-produced. As a response, skilful craftsmanship often re-emerges, together with distinctive styles incorporating the deeper cultural belliefs of the host society. This phase is a response to the deleterious impacts evident in the second phase.

Impacts on architecture, which is another form of material culture, are of another nature. These arise mostly because tourist buildings are not built according to local architectural traditions. International standardisation of the architectural properties of tourist facilities has created a uniform look and feel of tourist resorts around the world. These resorts seldom blend in well with the local scenery and architectural customs.

Impacts on non-material culture, such as dance or religious manifestations, are similar to impacts on material art forms. Here too ${ }$ cultural expressions may lose their deeper significance when confronted with commercialisation. But tourism may also give rise to a revival of old art forms, perhaps mixed with influences from other cultures.

These two impacts are not as mutually exclusive as they may seem at first sight. Commercially produced art forms without significance, also called fake art or airport art, may be used to distract tourist attention from the real cultural expressions by the local population. In general ${ }$ tourists seek "typical" forms of local culture, which they can buy as typical souvenirs, or see as exhibitions of the local way of life in specially designed imitation villages. In such settings, visual or audible art forms, such as local dances or songs can be performed. At the same time, locals can enjoy their own cultural manifestations " which may be less typical in they eyes of the tourist but more authentic and contemporary. This kind of arrangements has its own drawbacks, however (see Chapter 4).

\subsection{Temporal and spatial concentration in tourism}

The impacts that were discussed in section 3.5 are not distributed evenly over time and space. It is well known that tourism activities are concentrated in certain seasons of the year, typically the ones with the best climatic conditions. In addition, the lion's share of global tourism is concentrated in very specific and geographically clearly delimited area. Section 3.6.1 discusses the causes and consequences of temporal concentration, i.e. seasonality. Butler's idea of the destination life cycle (Butler, 1980) is used as a framework for studying the causes and effects of spatial concentration in section 3.6.2. 


\subsubsection{SEASONALITY}

The issue of seasonality in tourism flows has attracted the attention of tourism researchers for several decades (e.g. BarOn, 1975; Baum and Hagen, 1999; Butler, 1994; Koenig and Bischoff, 2004; Soesilo and Mings, 1987), and seasonality has been described as one of the most problematic yet least understood features of the tourism industry (Higham and Hinch, 2002; Jang, 2004). To date, seasonality research has tended to focus on the causes and consequences of this phenomenon, its measurement, and means of mitigation.

The causes of seasonality can be divided into two broad groups of factors: natural and institutional (BarOn, 1975; Hartmann, 1986). Natural factors relate primarily to a destination's climate, including annual variations in variables such as temperature, precipitation, wind speed, humidity and snow depth (Butler, 1994). Institutional factors are those that reflect the social norms and practices of society, and include the timing of religious (e.g., Christmas and Easter), school, agricultural and industrial festivals and holidays (Hinch and Hickey, 1997). Butler (Butler, 1994) added three additional causes to this initial pair social pressure or fashion, sporting seasons, and inertia or tradition on the part of tourists - though all might be considered to fall under the institutional heading if considered at its broadest.

Seasonality has potentially significant consequences for destination regions, as summarized by Koenig and Bischoff (2004). From an economic perspective, excess seasonality, and the fluctuations between under and over capacity it generates, can negatively impact profits, the attraction of investment capital, and the employment situation. Environmentally, the peak season concentration of visitors can place a considerable strain on the local environment, with implications for water supply, trash disposal, congestion, and erosion, among others. Similarly, local people may also be disadvantaged by seasonal strains on community services and infrastructure.

While it is important to recognize that seasonality may also have its advantages, most notably in the opportunities for ecological and community recovery provided during the off-season (as noted by, e.g., Butler, 1994; Hartmann, 1986), considerable research and policy attention has been placed on the reduction of tourism seasonality. While the climatic causes of seasonality have traditionally been considered relatively stable and predictable, substantial policy-making and marketing energy has been devoted toward altering institutional factors such as the timing and length of school holidays, and human tradition and inertia. Tourism planners, developers, and managers, meanwhile, have focused on product and market diversification, extending the existing season into the shoulder periods and offering new, year-round recreation opportunities, often in combination with the reaching out to new market 
segments - such as senior citizens, conference and event planners, and special interest tourists - and aggressive pricing strategies (e.g. Baum and Hagen, 1999). The relevance of climate change for seasonality, and for the urgency of improving our understanding of this phenomenon, has only very recently been recoginized in the seasonality iterature (Koenig and Bischoff, 2004), and has yet to receive sufficient attention in empirical analyses.

\subsubsection{SPATIAL CONCENTRATION}

Tourist activities are not evenly distributed over the world. Coastal zones and mountainous areas are among the most visited types of regions. Within these popular areas, tourist life is grouped around nuclei of facilities and infrastructure. Some towns and cities develop into large tourist centres, whereas others do not. Whether or not an area develops into a tourist centre is often a mix of 'objective' determinants on the one hand, and chance and the work of individuals on the other. The list of objective determinants may include the presence of special natural or cultural resources, and the vicinity of an airport. Historical incidents, entrepreneurship, and positive feedback do the rest. Russell and Faulkner (2004) report on two Australian towns with very similar starting positions. Because of historical incidence and imitation among entrepreneurs, one developed in a major tourist centre and the other did not.

The destination life cycle (Butler, 1980) describes the process of positive feedback effects that occur as a destination develops from a situation of little or no tourism into a tourist centre (see Figure 3.3). This pracess involves a structural transformation of the whole local community and can therefore be characterised as a transition. The first stage of the destination transition (i.e. discovery) takes place before any tourist-focused development has occurred. In this predevelopment stage, the destination remains unchanged by tourism and there is an intensive contact between the few visitors and the local people. In the second phase (the local control phase), tourism takes off. There are local initiatives to cater for visitors, resulting in an expansion of tourist-related capital and employment opportunities. In the third phase (i.e. institutionalisation), tourism development accelerates. The need for large investments and specialised skills attracts external companies and reduces local control over tourism development. With increasing numbers and popularity, problems of over-use and deterioration of facilities may cause the quality of the destination to change. Often, the absence of planning and regulation exacerbate these problems. In the final phase, i.e. stagnation, rejuvenation or decline, the destination is no longer fashionable. In this stabilisation phase, the destination has lost most of its initial ecological and cultural attraction, and is now vulnerable to more socially oriented changes in fashion. In order to avoid decline, the destination must develop new attractions or change tourists' perceptions. 


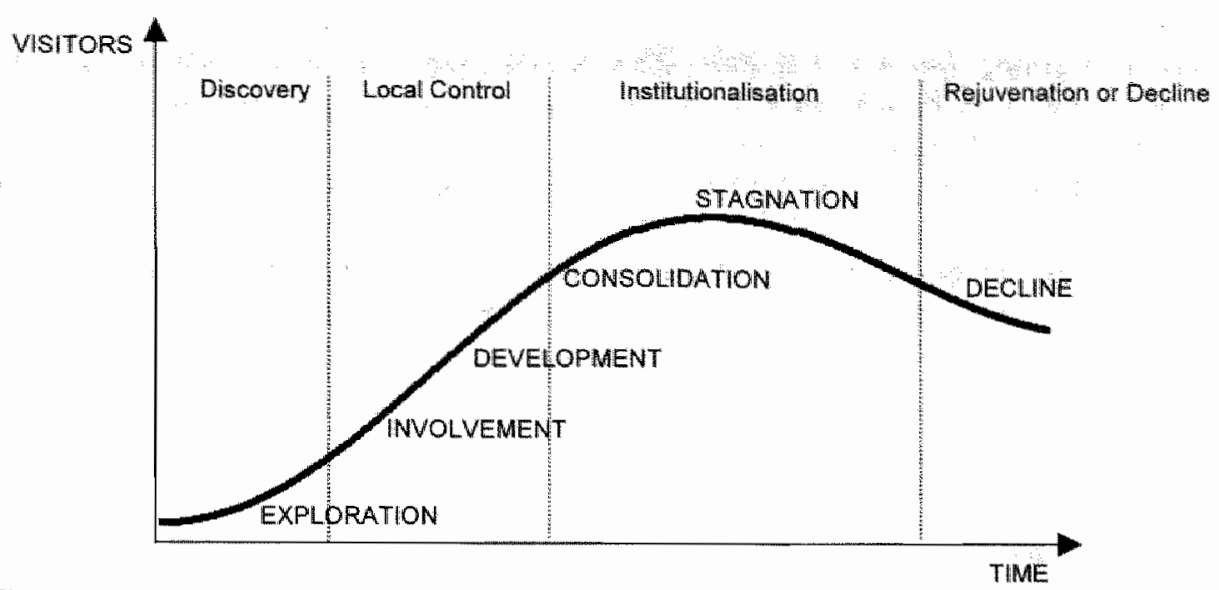

Figure 3.3: The destination life cycle

Source: $\quad$ Adapted from Butler (1980)

The destination life cycle is no law of nature; it is a framework to study the development of tourist destinations. This development can be altered in each phase by policy measures. Nevertheless, authors such as Butler (1991) are sceptical of attempts to limit or control the development of tourism.

\section{References}

Amelung, S. B. (1997). "Tourism, Environment and Policy in Costa Rica: Analysis and Simulation", MA thesis, Free University of Amsterdam: Amsterdam, The Netherlands.

Aylward B., Allen, K., Echeverría, J. and Tosi. J. (1996). "Sustainable Ecotourism in Costa Rica: The Monteverde Cloud Forest Preserve." Biodiversity and Conservation, $5(3): 315-344$.

Baaijens, S. R., Nijkamp. P. and Van Montfort, K. (1998). "Explanatory Meta-Analysis for the Comparison and Transfer of Regional Tourist Income Multipliers." Regional Studies, 32(9): $839-850$.

BarOm, R. (1975). "Seasonality in Tourism: A Guide to the Analysis of Seasonality and Trends for Policy Making." Economist Intelligence Unit: London, UK.

Baum. T. and Hagen, L. (1999). "Responses to Seasonality: The Experiences of Peripheral Destinations." International Joumal of Tourism Research, 1(4): 299-312.

Brown, F. (1998). Tourism Reassessed: Bight or Blessing?, Butterworth-Heinemann: Oxford.

Burns, P. and Holden, A. (1995). Tourism: A New Perspective, Prentice Hall: London.

Butler, R. (1980). "The Concept of Tourist Area Cycle of Evolution: Implications for Management of Resources." Canadian Geographer, 24(1): 5-12.

Butler, R. (1991). "Tourism, Environment and Sustainable Development." Environmental Conservation, 18(3): 201-209.

Butler, R. W. (1994). "Seasonality in Tourism: Issues and Problems." in: Seaton, A. V. (ed.) Tourism: The State of the Art, Wiley \& Sons: Chichester, 332-339. 
Cater, E. (1887). "Tourim in the Least Developed Countries." Arnals of Tourism Research, 14(2): 202-226.

Chadwick, R. (1994). "Concepts, Definitions and Measures Used in Travel and Tourism Research." in: Ritchie, J. R. B. and Goeldner, C. (eds.) Travel, Tourism and Hospitality Research: A Handbook for Managers and Researchers, Wiley: New York. USA.

Coelho, P. R, and McClure, J. E. (1993) "Toward an Economic Theory of Fashion." Economic Inquiry, 31(4): 595-608.

Cooper, C. and Jackson, S. (1996). "Destination Life Cycle: The Isle of Man Case Study." in: France. L. (ed) The Earthscan Reader in Sustainable Tourism, Earthscan Publications Limited: London, UK, 54-60.

France, L. (ed.) (1997). The Earthscan Reader in Sustainable Tourism, Eartschan Publications: London. UK.

Gossling. S. (2002). "Global Enwironmental Consequences of Tourism." Global Enviranmental Change, 12(4): 283-302.

Gray, P. (1970). International Travel - International Trade, LexingtonBooks: Lexington, Massachussets.

Hartmann, R. (1986). "Tourism, Seasonality and Social Change." Leisure Stiddies, 5: 25-33.

Higham, J. and Hinch, T. (2002). "Tourism, Sport and Seasons: The Challenges and Potential of Overcoming Seasonality in the Sport and Tourism Sectors." Tourism Management, 23(2): 175185.

Hinch, T. and Hickey, G. (1997). "Tourism Attractions and Seasonality: Spatial Relationships in Alberta." Proceedings of the Travel and Tourism Research Association, Canadian Chapter, Winnipeg, Canada.

Hinch, T. D. and Jackson, E. L. (2000). "Leisure Constraints Research: Its Value as a Framework for Understanding Tourism Seasonability." Current Issues in Tourism, 3(2): 87-106.

Holden, A. (2000). Environment and Tourism, Routledge: Londlon, UK.

Holloway, J. (1989). The Business of Tourism, Pitman Publishing: London.

Huynem, M. T. E., Martens, P. and Hilderink, H. B. M. (2005). "The Health Impacts of Globalisation: A Conceptual Framework." Globalization and Health, 1(14).

Jang, S. C. (2004). "Mitigating Tourism Seasonality - a Quantitative Approach." Annals of Tourism Research, 31(4): 819-836.

Kent, M. Newnham, R. and Essex, S. (2002). "Tourism and Sustainable Water Supply in Mallorca: A Geographical Analysis." Applied Geography, 22(4): 351-374.

Kevan, S. M. (1993). "Quests for Cures: A History of Tourisim for Climate and Health." International Journal of Biometeorology, 37(3): 113-124.

Kleeman, G., Forrest, J., Hamper, D., Rhodes, H., Smith, S., Epps, R., Lloyd, C., Rugendyke, B. and Sherval, M. (2000). A Geography of Global Interactions 2, Heinemann: Port Melboume.

KNTO (2006) "Key Facts on Tourism: Departures of Koreans." Korea National Tourism Organisation: Seoul.

Koenig, N. and Bischoff, E. E. (2004). "Seasonality Research: The State of the Art." Working Paper 2004/3, European Business Management School, University of Wales Swansea: Swansea, United Kingdom.

Korea Ministry of Culture and Sports (1995). "Monthly Statistics of Tourism." South Korea.

Lewis, I., Semeijn, J. and Talalayevky, A. (1998). "The Impact of Information Technology on Travel Agents." Transportation joumal, 37(4): 20-25.

Lohmann, M. and Kaim, E. (1999). "Weather and Holiday Destination Preferences, Image Attitude and Experience." The Tourist Review, 54(2): 54-64. 
Marcussen (2003). "Trends in European Internet Distribution of Travel and Tourism Services." World Tourism \& Travel Council: London.

Maslow. A. H. (1954). Motivation and Personality, Harper \& Row: New York, USA.

Mathieson, A. and Wall, G. (1982). Tourism: Economic, Physical and Social Impacts, Longman: London, UK.

Max-Neef, M. (1992). "Development and Human Needs." in: Max-Neef, M. and Ekins, P. (eds.) Real-Life Economics: Understanding Wealth Creation. Routledge: London, UK.

Miller, C. M. Mclntyre, S. H. and Mantrala, M. K. (1993). "Toward Formalizing Fashion Theory." Journal of Marketing Research, 30(2): 142-157.

Pearce, D. (1981). Tourist Development, Longman: New York.

Perry, A. (1993). "Climate and Weather Information for the Package Holiday-Maker." Weather. 48(12): $410-414$.

Prosser, $R_{n}$ (1994). "Societal Change and the Growth in Alternative Tourism." in: Cater, E. and Lowman, G. (eds.) Ecotourism: A Sustainable Option?, John Wiley \& Sons Ltd.: Chichester.

Rotmans, J., De Groot ${ }^{\text {D. }}$. and Van Vliet, A. (2001). "Biodiversity: Luxury or Necessity." in: Rotmans, J. and Martens, P. (eds.) Transitions in a Globalising World.

Russell, R, and Faulkner, B. (2004). "Entrepreneurship, Chaos and the Tourism Area Lifecycle." Annals of Tourism Research, 31(3): 556-579.

Sharpley, R. (2000). "Tourism and Sustainable Development: Exploring the Theroretical Divide." Journal of Sustainable Tourism, 8(1): 1-19.

Soesilo, J. and Mings, R. (1987). "Assessing the Seasonality of Tourism." Visions in Leisure and Business, 6(2): 25-38.

UNESCO (1976). "The Effects of Tourism on Socio-Cultural Values." Annals of Tourism Research, 4(2): 74-105.

WTO (1995). Gabal Tourism Forecasts to the Year 2000 and Beyond, World Tourism Organisation: Madrid, Spain.

WTO (1997). Yearbook of Tourism Statistics, World tourism organization: Madrid, Spain.

WTO (1998). Tourism Economic Report, World Tourism Organization: Madrid, Spain.

WTO (2002). "Tourism Market Trends 2002 - Europe." World Tourism Organization: Madrid, Spain.

WTTC (2004). "Travel \& Tourism, Forging Ahead: Executive Summary." World Travel \& Tourism Council: Landon. 



\section{Chapter 4}

Structural barriers to socially sustainable tourism development: evidence from Mombassa Old Town 



\subsection{Introduction}

The dynamics of tourism development are complex and often chaotic, whether they are studied on a global, regional or local level. The causal relationships are very different on each level, and the lower the level of analysis, the more important local specifics are. This chapter focuses on cultural tourism in the city of Mombassa, Kenya. The specific combination of cultural attractions, ethnic characteristics of the population, and individual stakeholders makes this case as unique as any other. The uneasy relationship between the tourist industry's objective of making a profit and the societal objective of poverty alleviation that emerges from the Mombassa case, however, is one that is felt throughout the world. The purpose of this chapter is to identify the mechanisms that go together with the business and societal objectives and to assess their compatibility.

In Kenya, tourism is widely being perceived as an opportunity for economic development and poverty alleviation. Nevertheless, many stakeholders are disappointed about the actual benefit they get out of tourism. This chapter contributes to the analysis of the mechanisms and structures that cause the discrepancy between the promise of pro-poor tourism and the reality of exclusion of these same poor. The case of Mombassa Old Town is analysed with concepts taken from the literatures on tourism sociology and corporate sustainability ${ }^{1}$.

\subsection{Sustainable tourism and its tensions}

Tourism has often been presented as a potential economic saviour of countries (Garrod, 1998), in particular of developing nations. The socio-economic benefits of tourism that are pursued include the generation of foreign exchange, the stimulation of economic growth, the generation of employment and the improvement of regional economic conditions. A particular attractive feature of tourism is its proclaimed very limited negative impact on the environment (Bachleitner and Zins, 1999). However, in the past two decades a growing body of evidence has developed to support the claim that tourism entails negative effects on social structures and cultural systems (Mathieson and Wall, 1982; Mowforth and Munt, 2000), as well as on the environment (Gössling, 2002).

The growing evidence of substantial negative impacts of tourism has accelerated the introduction of sustainability concepts in tourism research.

1 Partly based on Lamers (2001), Machiel Lamers' MA thesis, written at ICIS and supervised by the author of this PhD thesis. 
Sustainable tourism has been one of the buzzwords in the academic literature on tourism as well as in the tourist industry. Most authors have taken a tourismcentred approach to sustainable tourism (Sharpley, 2000), stating that the economic benefits of tourism should be maximised, while minimising the negative social and environmental impacts. Next to this defensive approach, a literature has developed that stresses the potential positive contributions that tourism can make to the environment and society, for example by increasing the value of natural parks (Dharmaratne et al., 2000) or by creating pride in local heritage (Brown, 1998). The World Tourism Organisation recently stated that "sustainable tourism can be one of the few development opportunities for the poor. Let us use it wisely and soon!" (WTO, 2002).

Sustainable development, including the special case of sustainable tourism development, implies that a balance be struck between developments in the economic ecological and sociocultural domains. Management and planning are usually seen as the appropriate instruments to ensure an acceptable outcome, and the public authorities are held responsible for their implementation. McKercher (1999) claims that the (conceptual or formal) models of tourism used strongly imply that an understanding of tourism emerges by understanding how each constituent part works; that individual tourism business function to achieve a set of common, mutually agreed upon goals; and that tourism can be controlled. "Implicit in all of these models is the assumption that tourism is a linear, deterministic activity, whose orderly development can be controlled from above by 'planners'. These models try to reinforce the bellief that tourism is predictable and that control over tourism is both possible and desirablle, while a loss of control poses a threat to desired tourism outcomes (McKercher, 1999)."

In reality, tourism is predominantly driven by demand, not by authorities. In fact, the influence of governments and other public authorities is dwindling as a result of globalisation, in particular in developing countries, it becomes increasingly clear that tourism development cannot be controlled or planned; it usually bears many signs of chaos (McKercher, 1999; Russell and Faulkner, 1999). Attention is therefore turning to the key 'chaos makers' in tourism, the entrepreneurs, who deliberately cause or take advantage of chaos to secure a profit.

Russell and Faulkner (1999) contend that there is a constant tension between the tourism entrepreneurs, who are the agents of change, and the authorities whose role it is to control change. As the influence and capacity of authorities to control developments diminish throughout the world, however, pressure is mounting on the business community to adopt part of this agenda (Keijzers, 2002). A large share of the corporate sustainability literature is dedicated to the quest for reconciliation of the objectives of making a profit, and of meeting 
societal requirements. Dyllick and Hockerts (2002) call these objectives 'socioefficiency' and 'socio-effectiveness'. In the context of tourism, the tourist industry strives for socio-efficiency by minimising its social-cultural input per unit of value added, while host communities aim for socio-effectiveness, expecting a positive contribution to society that is the maximum achievable in an absolute sense.

Standardisation is one of the mechanisms through which businesses try to increase their efficiency. In the case of cultural tourism, this standardisation often takes the form of staging: performances at predetermined times that are directed exclusively to tourists. Staging requires a considerable level of control by the director of the performances, so that the level of perceived ambiguity can be kept to a minimum. As a result, staged performances often take place in enclavic tourist spaces, i.e. places that are exclusively used for tourism purposes (Edensor, 2001). While a substantial literature has developed on staging and enclavic tourist spaces in relation to 'meaning' and 'authenticity', its implications for the distribution of tourist expenditure and other tourism effects have not received much attention in academia.

This chapter analyses the distributional effects of developing cultural tourism in Mombassa, Kenya. A substantial share of the population is dissatisfied with the current distribution of tourism revenues. This chapter argues that this dissatisfaction can be explained from the incompatibility between the objective of socio-effectiveness and the mechanisms that have been put in place to further the objective of socio-efficiency. It is also argued that this incompatibility is linked to historical and current demand patterns and the accompanying structure of the international tourist industry. Increased heterogeneity in tourist demand and increased local involvement may narrow the gap between socioeffectiveness and socio-efficiency.

Section three introduces the case study of Mombassa Old Town in the context of overall tourism development in Kenya. Section four details the concepts of socio-efficiency and socio-effectiveness, linking these back to sustainable (tourism) development and forward to the issue of staging. In section five, the methodological concepts of section four are applied to the Mombassa case study. Section six discusses the results and section seven closes the chapter with conclusions.

\subsection{An introduction to cultural tourism in Mombassa}

In the years since its independence in 1962, Kenya has embraced tourism as a tool for socio-economic development (Akama, 1999). According to Akama (2002) "the principal objectives of tourism planning and development should 
include: enhancement of equitable distribution of tourism revenues; increasing local participation in tourism decision-making; reduction of the high leakage rates and increase in the multiplier effects of tourism; and minimisation of the social and environmental impacts of tourism." The country has become an important tourist destination, with safari trips as the country's main and most unique tourist products. The beach resorts along the Indian Ocean coastline around Mombassa, and the city of Nairobi are attractions of a more recent date, but they too have become popular destinations for tourists. Since the 1960 s, total visitor numbers thave risen considerably, to around 840 thousand in 2002 . As can be seen in Figure 4.1, this growth has not been steady: periods of growth were interrupted by periods of stagnation and downturn.

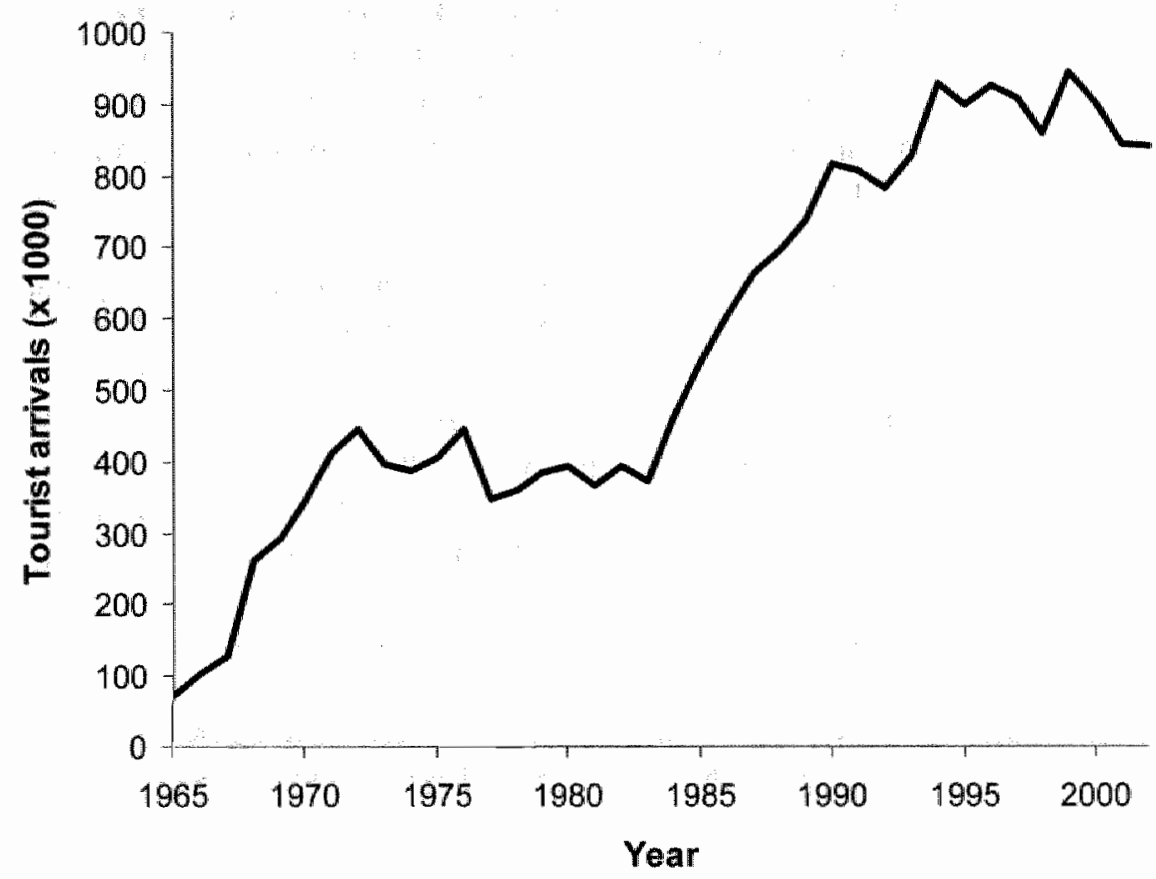

Figure 4.1: Tourist arrivals in Kenya $a_{4} 1964-1999$

Source: World Tourism Organisation

The stagnation of the late seventies and the early eighties is attributable to the oil crises in that period and the ensuing economic recessions. The receding tourist numbers in the 1990s have other causes. Kenya was beginning to feel the competition from neighbouring countries such as Uganda and Tanzania, which had improved on political stability, security and human rights and offered the same type of safari-based tourism. At the same time, Kenya's own image suffered heavily from acts of violence and natural disasters on its own territory, such as the Likoni tribal clashes and heavy El Niño rains in 1997, and the 
terrorist attack on the American Embassy in Nairobi in 1998 (Akama, 1999). The coastal region was among the most affected tourist destinations (Kareithi, 2003).

With the aim of countering the negative trends in tourist arrivals, Kenya has been trying to diversify its range of tourism products, among others by capitalising on its cultural diversity. Acknowledging their secondary importance, cultural and historical elements are seen as add-ons to the major attractions of wildlife and the beach, which reflects traditional tourist perceptions of Kenya's main attractions (Pacific Consultants International, 1995). In this scheme, elements of the Maasai culture have been integrated with safari activities (Berger, 1996; Olindo, 1997), and elements of the coastal Swahili culture are being integrated with beach tourism. Excursions to the Gedi Ruins and Mombassa are examples of the latter category.

The main cultural attractions of the Swahili city of Mombassa are located in Mombassa Old Town, the area between Fort Jesus and the Old Harbour. Fort Jesus, built by the Portuguese in the 16 th century to control the region, is the single most important historical landmark of the Old Town. Numerous carpentry and curio shops add to Mombassa's unique atmosphere. Reflecting the national trend in an amplified form, visitation levels to Fort Jesus and the Old Town showed a remarkable drop in 1997 and 1998, and slightly recovered in 1999 and 2000 (Abubakar, 2001). Due to social turmoil at the coast, tourists may have refrained from visiting cultural attractions in favour of sticking to the safe 'environmental bubble' (Sharpley, 1999) of the beach resorts.

The tourism activities in Mombassa Old Town can be classified as cultural tourism, which in the definition proposed by Craik (1997) "consists of customised excursions into other cultures and places to learn about their people, lifestyle, heritage and arts in an informed way that genuinely represents those cultures and their historical contexts." Most foreign visitors to Mombassa visit the city on an organised excursion, during which they want to be entertained and experience something typically African. The operating bases of these mass tourists are the coastal resorts around Mombassa, where they spend most of their holidays. In the Old Town itself, no hotels or guesthouses have so far been developed to accommodate tourists.

In spite of the large numbers of visitors to the Old Town that could potentially bring economic benefits to the city, there is considerable resentment against tourism, in particular amongst the Swahili population of Mombassa. Musyoki (1994) found that the ethnic groups that perceive the social effects of tourism most negatively are the ones that have the longest history of living in the coastal areas, i.e. the Arabs, the Swahili and the Bajuni. With their families to support, 
they perceive themselves to be more vulnerable than the up-country migrants, who are often single (Rakodi et al,, 2000). According to Sindiga (1995), the Swahili are not opposed to tourism as such; they are opposed to certain phenomena that are associated with tourism, such as the consumption of alcohol, and un-Islamic habits such as scant dressing.

Whatever the reason, the Swahili's participation in tourism activities has been limited, which is in contrast with their participation in economic life in general (Eastman, 1995). The enclave nature of mass tourism development, which limits host-guest encounters, may have encouraged their attitude of keeping tourism and its impacts at bay (Sindiga, 1995). In addition, there is no clear indication that the coastal peoples received any significant socio-cultural benefits from tourism (Musyoki, 1994).

A controversial project in Mombassa Old Town is a conservation project to renovate the Old Town's buildings in traditional style, whereby residents are supported financially. The house owner pays $25 \%$ of the renovation costs whereas the rest will be covered by a fund made available by the European Union. The idea is to save the traditional build heritage, to make the old town more attractive for tourists, and simultaneously make the residents benefit from this both now and in the future. Although the residents find the financial benefits appealing, they are critical about the project because they allegedly have little say in the way in which the houses and building are being renovated.

\subsection{Socio-effectiveness, socio-efficiency and staging}

Dyllick and Hockerts (2002) introduce a model with which the tensions can be studied that exist between the three complementary goals of sustainability, i.e. efficiency, equity, and resilience. According to Dyllick and Hockerts, many businesses and academic scholars have focused on the "business case' for sustainable development, i.e. on ways to establish economic sustainability by paying attention to social and environmental efficiency. However, the natural and social stocks on which businesses thrive are non-substitutable, non-linear and irreversible. Therefore firms cannot limit themselves to the business case for corporate sustainability; they have to address the two alternative cases as well. Dyllick and Hockerts argue that corporate sustainability can be reached when there is a balance between these three domains and the stakeholders that are involved in these dimensions. In this chapter, attention is focused on the tensions between the business case and the societal case. According to Dyllick and Hockerts, the business case benefits from increased socio-efficiency (decreased social input per unit of value added), while the societal case benefits 
from increased socio-effectiveness (increased positive social effects in an absolute sense).

One of the industrial answers to the need to increase efficiency is standardisation. Economies of scale and the benefits of specialisation can be captured by standardising products and production processes. In the context of cultural tourism, standardisation is often strived for through a process of staging. Staged performances or artefacts convey controlled messages to the spectators in a controlled environment. Rather than waiting for host communities to plan their own performances, the tourist industry prefers standardised performances at regular times. And rather than leaving tourists to discover a city by themselves, the tourist industry prefers selling guided tours through the city. This process of staging provides the tourists with a coherent set of experiences that have a clear meaning, and it provides the tourist industry with clearly described products to sell.

The literature on the anthropological and sociological meaning of staging is substantial. MacCannel (1989) uses the theatre metaphor of front stage and back stage (or front and back region) to describe this dichotomy. A good example of the concept is the contrast between the beautiful dining room and the grimy kitchen of a restaurant. The guest in the restaurant does not need (or want) to know what happens in the kitchen, as long as his meal tastes good and looks fine. With this 'staging' the tourist industry anticipates on the expectations of the tourists, and their spatial and temporal constraints, and adjusts the performances accordingly. The practice of staging implies a distinction between on-stage and off-stage reality. The show takes place in an area of play and make-believe to meet the 'tourist gaze' (Urry "2002), while the authentic cultural expressions occur in areas that tourists rarely reach.

The division in front and back regions can result through physical as well as social boundaries. By creating these boundaries, the tourist industry can control the encounters between tourists, attractions and other actors, and create a safe and well-organised environment for the tourists. Edensor (2000) makes a difference between enclavic tourist space and heterogeneous tourist space. Enclavic spaces are the areas that are purely designed and built for tourism or recreational purposes, such as hotels and adjacent beaches, amusement parks, museums and other attractions. Heterogeneous spaces are areas with a mixed purpose; these are areas where tourist facilities co-exist with locall businesses, street vendors, public and private institutions and domestic housing.

The distinction between front and back regions is, however, not always sharp and static. Boundaries are often the product of social processes, and are thus constantly shifting. Some actors (to stick to the theatre metaphor) are especially 
dedicated to mediating between the front and back regions. In the example of the restaurant there are at least three actors involved, namely the guest (consumer), the cook (producer) and the waiter (intermediary person). In local tourist settings the same roles and their interplay tend to recur.

The role of intermediary does not necessarily coincide with that of director. In restaurants, the manager usually has considerable influence on the menu, the costumes that the employees wear, the prices charged etc. In many tourist settings it is the intermediary actor who takes on the role of director, as for example in the case of tourist guides. The director has a lot of power in performance situations, which he is sometimes able to exploit or abuse, in particular in non-institutionalised settings.

For mass tourists, the difference between the front region and the back region is rather clear. The front region represents the areas that are familiar, relaxing and safe; the back region represents the areas that are unknown, risky and exciting. The companies that cater for the tourists in the front region are eager to confirm this view of the situation. The complex of facilities constituting the front region (or enclave) is organised to provide a self-contained environment where tourists are encouraged to spend as much money as possible (Edensor, 2000).

From an efficiency-versus-effectiveness perspective, the process of staging boils down to the exclusion of as many stakeholders as possible, to maximise revenues for the entrepreneur who stages the performance. This may be beneficial for the few members of the local community who are active on the front stage, but these may be the 'islands of social excellence in a sea of social discontent' that Dyllick and Hockerts (2002) refer to.

\subsection{Staging and socio-efficiency in Mombassa Old Town}

Mombassa Old Town is a spatial area that Edensor would categorise as heterogeneous tourist space (Edensor, 2000). Although we cannot claim that Mombassa Old Town is a staged environment especially designed for the entertainment of tourists, there are elements in the spatial organisation and the architecture that are maintained especially for tourists. In the area between Fort Jesus and the Old Harbour, there are numerous curio shops, souvenir stalls, furniture shops and exchange offices to cater for the visitors. There are hardly any shops that target the residents of Old Town. Many houses in this area are renovated for the conservation of the typical Swahili architecture.

Fort Jesus and the Old Town conservation project are examples of the kind of staging that the government is developing in Mombassa. Most of the souvenir 
shops and stalls are examples of accidental forms of staging. They were not put there by a tour company or government body but by local entrepreneurs, keen on earning some money from the tourists who visit Fort Jesus and the Old Town. Many of these entrepreneurs come from up-country areas, such as the Maasai and Samburu men who go to the coast to work as a security guard for souvenir shops. It is their job to stand in front of the shop all day dressed in their colourful traditional cloth to attract tourists into the shop. Classic are also the 'beach boys' who roam around near beach hotels trying to sell souvenirs, drugs, snorkelling trips or even complete safari trips to tourists.

In particular in the case of cultural tourism, there may be tensions between maintaining the cultural attractiveness for tourism and achieving the economic development and social change desired by the community. For a detailed analysis of these tensions in Mombassa, the reader is referred to Lamers (2001). The Old Town renovation project imposes strict rules on the use and maintenance of property. In practice, these rules restrict people in using their property for other purposes than tourism. This effectively turns Mombassa Old Town into a mono-economy, or an enclavic tourist space.

Mombassa Old Town is dependent on the coastal resorts for a steady flow of tourists into the city. In Kenya, foreign ownership and vertical integration in the tourist business is widespread (Akama, 1999; Sinclair et al., 1992; Sindiga, 1999). Examples include Abercrombie \& Kent, Pollman's Tours, African Safari Club and United Touring Company. All these businesses own hotels, lodges and tour operating units. The African Safari Club even owns a chartered airline and a wildlife resort. Several of these companies belong to large multinational conglomerates. The structure of the industry directly influences the net gains from tourism. The largest share of total tourist expenditure is usually spent on transport and accommodation, and it thus makes a large difference where and when these services are bought. In a study on tourism in developing countries, Cater (1987) reports that the net gains from tourism can be as low as 10 percent. For Kenya, this percentage is estimated at around 30 percent (Sindiga, 1999).

The large companies that sell the beach holiday packages offer excursions to Mombassa Old Town and other places as an addition to the facilities in the beach enclaves. These guided excursions are sold as products consisting of experiences of Kenyan culture and history. Tourists are of course free to visit Mombassa on their own, but many refrain from doing that because of safety concerns. Resort personnel often spread stories of safety problems, which are beneficial to the company as they may persuade tourists into paying for a guided excursion. A young Australian tourist observes: "They really try to keep you in the hotel. The first evening there is a welcoming evening, there is a 
discussion where they tell you things like: Don't go there. Don't do this. Don't go to the beach. Don't buy anything there. There are people who offer you safaris but they will leave you somewhere and rob you. Only go with us. It's all a little bit exaggerated. They want to hold you in your hotel and they want to sell these things to you themselves (Lamers, 2001: 55)"

Typically, feelings of fear and insecurity are widespread among package deal tourists. One American tourist that Lamers interviewed did not leave the hotel north of Mombassa where he and his wife had arrived more than a week before. Many tourists perceive the act of leaving the hotel and walking around in the city of Mombassa all by themselves as a risky expedition. Issues such as the risks of being mugged or robbed are important in the discourse of mass tourists in Mombassa.

Therefore, package deal tourists often purchase cultural excursions in their hotel with the tour company that they travel with. These cultural excursions often encompass a visit to Fort Jesus, a walk through Mombassa Old Town with a visit to a designated curio shop and a visit to one of the cultural centres near Mombassa, such as Bombolulu or Ngomongo where tourists can eat traditional African food and watch traditional (tribali) dancing. For the tourists these excursions are an exciting change from the beach where they reside, whereas for the guides and shopkeepers of Old Town these excursions are the only opportunities they have to benefit from tourism. For these potential benefits to materialise, however, the small businesses have to succeed in contacting the tourists, which is something the tour guides try to prevent.

These tour guides have an interest in upholding the myth of danger to keep the group of tourists together. The tourists are told that local curio sellers will rip them off or that the small souvenir shops sell fake products. Tourists consequently follow the guide to one of the larger souvenir shops that have agreed to pay the guide some commission.

Contacts with other shop owners and residents of the Old Town are kept to a minimum. This often leads to frustration among tourists. A couple remarks: "We haven't been to Mombassa town yet but we have been there before. (...) We did half a day tour the last time we were here. They just briefly show you, they don't show you enough. They just want to give you a rough idea. I think that next time I could go down and do that on my own. I think that I could walk around on my own (Lamers, 2001: 50)."

According to many of the stakeholders who do not operate in the front region, the hotels and the tour companies are structurally misinforming tourists about the local people in Mombassa Old Town. A resident of the Old Town complains 
about these misinformation practices. "They shouldn't give them a lecture by saying: 'Don't talk to these people, these are bad people', as they do now. Tourists get afraid (Lamers, 2001: 40)."

There is little sign of change, however. Being asked about these practices, one of the tour companies states that there is nothing that he can do about it. "A classic example is the selling of curio's (souvenirs). All the drivers have their favourite curio stands. They will take their tourists and they get a percentage of the taking. I wouldn't be surprised if one of my drivers would do that. I tell them not to but you are not going to stop people if there is a money incentive (Lamers, 2001: 55-56)."

Listening to the community it becomes clear that many residents are not pleased with the current flow of tourists and not convinced of the social improvements that are associated with tourism development. "I want to see these tourists complement my way of life, I want to see improvements in my life as a result of more tourists coming to this country. I don't see that (Lamers, 2001:38)." According to many residents, too little is being done by the tourist industry and the government to improve the societal capital of the community and to make tourism more effective in poverty reduction.

According to many residents of Mombassa the community is "not part of the tourism jigsaw puzzle" and subsequently does not benefit. In the meanwhile residents play a very important role in conserving the attractiveness of the place. A resident of Old Town notes: "If you look at what they get from these tourists going in and out of the place, nothing. I have seen so many tourists that are being put in the Fort Jesus Museum, that are going to see the Old Town of Mombassa. Residents of the Old Town always have to be nice and say: 'Hi, Jambo.' That is a very important feature as far as the attraction is concerned (Lamers, 2001: 54)."

The feeling of exclusion motivates local vendors of curio to interfere in the staging process. Many of these people will position themselves on the beach or in other strategic places to follow the tourists around and confronting them with their goods, hoping to seduce them into buying something. In combination with the ongoing misinformation by tour companies and hotels, this leads to frustration and annoyance among the tourists. Even the tourists that are trying very hard to understand why they are being followed around have to acknowledge that these encounters spoil their holiday experience. 


\subsection{Discussion and conclusions}

Tourism is often hailed as an effective tool for economic development and poverty alleviation, but these societal objectives turn out to be difficult to accomplish. Most of the tourism literature on pro-poor and sustainable tourism is directed to the support of policy making and tourism management by public authorities. In the current phase of privatisation and globalisation, however, the influence of governments and other public bodies diminishes. The balance of power is shifting to the business community, in particular to multinational companies.

Simultaneously, the business community is increasingly expected to take responsibility for accomplishing societal goals. Businesses are challenged to incorporate societal goals into their daily practices. Companies are forced to look beyond the business case of sustainability, which focuses on efficiency considerations, and include the societal and natural cases, which focus on equity and resilience issues. The tensions between the commercial goal of social efficiency and the societal goal of social effectiveness are key for understanding the underlying mechanisms that result in the disappointing social results of tourism development.

Cultural tourism in Mombassa Old Town was studied to reveal some of these mechanisms. Standardising tourism products through staging appears to be the dominant way for tourism companies to reach increased socio-efficiency. Distracting elements in the cultural performances are removed as much as possible, securing a reliable experience for the tourists. The back stage environment is represented as being a dangerous no-go area. While this process of staging may be understandable and even beneficial from the perspective of tourists and the tourist company, it leads to the exclusion of other social actors.

Both the local community in Mombassa Old Town and the tourists are starting to revolt against this process of exclusion. The local population tries to break into the front stage of cultural performances by actively looking for tourists on the beach, in town or elsewhere. At the same time, some of the tourists are not satisfied with the standardised undifferentiated cultural experiences and explore the city on their own.

It is hard to imagine a stable and sustainable form of cultural tourism developing when key stakeholders are incapable of fulfilling their own needs for survival. After all, they are the 'owners' of the cultural heritage that is consumed. Cultural tourism without the participation of the local community leads to a strange form of coexistence of static cultural attractions on the one hand and living, changing 
culture of the community on the other side. This chapter shows that it is difficult to meet the high expectations about tourism as a tool for development and poverty reduction in developing countries. The development of cultural tourism would currently onlly mean a more sustainable tourism industry.

\section{References}

Abubakar, A. (2001). "Visitation to Fort Jesus: 1996-2001." Fort Jesus Museum, Mombassa, Kenya. Akama, J. S. (1999)" "The Evolution of Tourism in Kenya." Journal of Sustainable Tourism, 7(1): 625.

Akama, J. S. (2002). "The Role of Government in the Development of Tourism in Kenya." International Joumal of Tourism Research, 4(1): 1-14.

Bachleitner, R. and Zins, A. H. (1999). "Cultural Tourism in Rural Communities" The Residents' Perspective." Journal of Business Research, 44(3): 199-209.

Berger, D. J. (1996). "The Challenge of Integrating Maasai Tradition with Tourism." in: Price, M. P: (ed.) People and Tourism in Fragile Environments, Wiley \& Sons: London.

Brown, F. (1998). Tourism Reassessed: Blight or Blessing?, Butterworth-Heinemann: Oxford.

Cater, E. (1987). "Tourim in the Least Developed Countries." Annals of Tourism Research, 14(2): $202-226$.

Craik, J. (1997). "The Culture of Tourism." in: Rojek, C. and Urry, J. (eds.) Touring Cultures. Transformations of Travel and Theory, Routledge: London, 113-136.

Dharmaratne, G. S., Yee Sang, F. and Walling, L. J. (2000). "Tourism Potentials for Financing Protected Areas." Annals of Tourism Research, 27(3): 590-610.

Dyllick, T. and Hockerts, K. (2002). "Beyond the Business Case for Corporate Sustainability." Business Strategy and the Environment, 11(2): 130-141.

Eastman, C. M. (1995). "Tourism in Kenya and the Marginalization of Swahili." Annals of Tourism Research, 22(1): 172-185.

Edensor, T. (2000). "Staging Tourism: Tourists as Performers." Annals of Tourism Research, 27(2): $322-344$

Edensor, T. (2001). "Performing Tourism, Staging Tourism." Tourist Studies, 1(1): 59-81.

Garrod, B. (1998). "Beyond the Rhetoric of Sustainable Tourism?" Tourism Management, 19(3): 199-212.

Gössling, S. (2002). "Global Environmental Consequences of Tourism." Global Environmental Change, 12(4): 283-302.

Kareithi, S. (2003). "Coping with Declining Tourism, Examples from Communities in Kenya." ProPoor Tourism Working Paper No. 13, University of Luton: Luton.

Keijzers, G. (2002). "The Transition to the Sustainable Enterprise." Journal of Cleaner Production, 10(4): 349-359.

Lamers, M. (2001). "Between Protection and Progress: An Actor Oriented Approach to Cultural Tourism Development in Kenya", MA Thesis, Universiteit Maastricht: Maastricht.

MacCannell, D. (1989). The Tourist. A New Theory of the Leisure Class, University of Calfornia Press: Los Angeles.

Mathieson, A. and Wall, G. (1982). Tourism: Economic, Physical and Social Impacts, Longman: London, UIK.

McKercher, B. (1999). "A Chaos Approach to Tourism." Tourism Management, 20(4): 425-434. 
Mowforth, $M$. and Hunt, I: (2000). Tourism and Sustainability. New Tourism in the Third World, Routledge: London, UK.

Musyoki, B. (1994). "Effects of Tourism on the Society and Culture of the Kenya Coastal Peoples." Unpulblished Contribution to the Department of Tourism Staff Seminar of 29 July 1994 Department of Tourism, Moi University: Eldoret.

Olindo, P. (1997). "The Old Man of Nature Tourism: Kenya." in: France, L. (ed.) Sustainable Toutism, Earthscan: London, 90-97.

Pacifie Consultants International (1995). "The Study on National Tourism Master Plan in the Republlic of Kenyal." Ministry of Tourism and Wildlife, Republic of Kenya: Nairobi.

Rakodi, $C_{n}$, Gatabaki-Kamau, R. and Devas, N. (2000). "Poverty and Political Conflict in Mombasa." Environment \& Urbanization, 12(1): 153 170.

Russell, R. and Faulkner, B. (1999). "Movers and Shakers: Chaos Makers in Tourism Development." Tourism Management, 20(4): 411-423.

Sharpley, R. (1999). Tourism Tourists, and Society, ELM Publications: Huntingdon, UK.

Sharpley, R. (2000). "Tourism and Sustainable Development: Exploring the Theroretical Divide." Joumal of Sustainable Tourism, 8(1): 1-19.

Sinclair, T. M., Alizadeh, P. and Onunga, E. A. A. (1992). "The Structure of International Tourism and Tourism Development in Kenya." in: Harrison, D. (ed.) Tourism and the Less Developed Countries, Belhaven: London, $47-63$.

Sindiga, I. (1995). "Coping with Tourism among the Waswahill:" Unpublished Contribution to the Department of Tourism Staff Seminar of 29 July 1994 Department of Tourism, Moi University: Eldoret.

Sindiga, I. (1999). Tourism and African Development: Change and Challenge of Tourism in Kenya, Ansgate: Aldershot, UK.

Urry, J. (2002). The Tourist Gaze; Sage Publications: London.

WTO (2002). "Tourism and Poverty Alleviation." World Tourism Organization: Madrid, Spain. 


\section{PART THREE}

The future of tourism 



\section{Chapter 5}

The future of tourism: a scenario analysis 



\subsection{Introduction}

In fifty years time, the phenomenon of tourism and its impacts have radically changed. From something belonging to the lives of the wealthy members of society, it has become inextricably bound up with the lives of the great mass of society, at least in the developed countries. As a result, the scale and scope of tourism's effects have greatly increased.

Both positive and negative consequences of tourism are stressed in the scientific literature (Brown, 1998; Burns and Holden, 1995; Mathieson and Wall, 1982; Pearce, 1981, see also Chapter 3). The positive aspects include the generation of income, employment and foreign currencies, the interaction between different cultures, and the contribution to nature conservation. Among the negative aspects are loss of economic control by locals in individual destinations, change of cultural identities, and ecological damage. There is concern that the scale and growth rate of tourism pose a threat to the ecosystems and cultures in destinations around the world. At the same time, however, there is recognition of tourism's economic potential.

How will these tensions work out in the future? Some take a pessimistic stance, holding that the sheer volume of tourism is a fundamental problem that cannot be resolved (Wheeller, 1991). Others are more optimistic, indicating that a bright future is possible, if destinations and operators invest the necessary resources to tackle the challenges that tourism faces (WTO, 1995). Such differences in expectations for the future arise because of the enormous uncertainties involved when exploring the future.

Reviews of trends in tourism (e.g. Faulkner and Valerio, 1995; Gartner and Lime, 2000b; Moisey and McCool, 2001) identify a large number of past and current trends, and a collection of potential future ones. These studies stress the uncertainties involved, without an explicit way to handle these. This chapter aims to fill this gap by grouping together compatible trends into a range of storylines and scenarios. Far from pretending to be able to predict the future, the aim is to explore the potential implications for tourism of a range of very different directions that major determinants for tourism could take.

\subsection{Scenario analysis and tourism}

Scenarios can aid the exploration of the future (see Chapter 2). They are descriptions of journeys to possible futures that reflect different perspectives on past, present and future developments with a view to anticipating the future (Van Notten and Rotmans, 2001). As the future is inherentlly uncertain, 
scenarios cannot predict; rather, they paint pictures of possible futures and explore the different outcomes associated with "what-if' questions (Greeuw et al. 2000 ).

Over the years, a number of storylines and scenarios have been developed that describe developments that are relevant for tourism, such as UNEP'S Glaball Environmental Outlook (UNEP, 2002), and IPCC's Special Report on Emissions Scenarios (Nakicenovic et al., 2000). Not all of the many available scenarios are compatible with the objectives of this chapter. To make an informed choice from the existing scenarios the scenario typology developed by Van Notten et all. (2003) was used. This typology clusters scenarios according to three features (see Figure 5.1):

- Goal: exploration versus decision-support

- Design: intuitive versus formal

- Content: complex versus simple

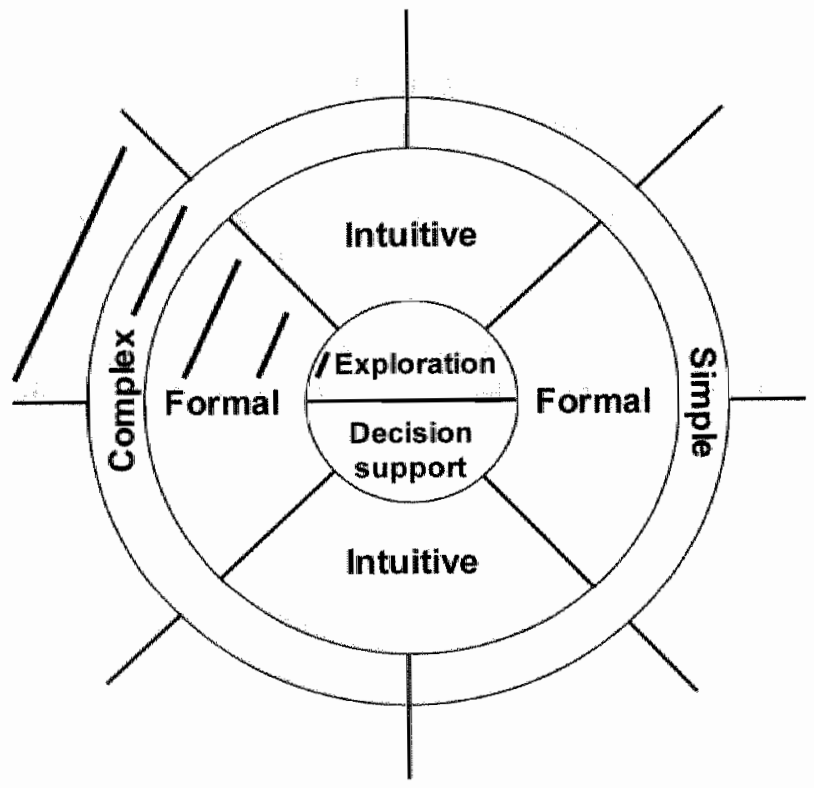

Figure 5.1: A scenario typology: the scenario cartwheel

Source: Adapted from Van Natten et al. (2003)

To meet the objectives of this chapter, the use of exploratory, formal, and complex scenarios is required. The scenarios should be exploratory because our analysis is driven by our own curiosity, rather than specific questions or concerns from policy-makers. They should be complex, because our exploration takes the interactions amongst a range of societal developments (see also Chapter 1) into account. A choice on the "intuitive versus formal" dimension is less self-evident. The exploration of tourism's future in this chapter is largely qualitative and does not require a formal model: an intuitive approach would 
satisfy the requirements. The following chapters on climate change impacts, however, take a more quantitative approach. Consistency between these chapters requires the use of scenarios with a formal background in all chapters.

There are few scenarios that are exploratory, formal, and complex, and relevant for tourism purposes at the same time. The main candidate is the SRES suite of scenarios developed by the Intergovernmental Panel on Climate Change (Nakicenovic et al., 2000). The IPCC framework was developed to study climate change and not tourism, but the driving forces it contains largely coincide with the determinants of tourism that were identified in Chapter 3. Rather than starting from scratch, our exploration was therefore planned to build on the SRES scenario suite.

Each of the four scenario families that the IPCC developed is based on different projections for the development of two factors. Both factors are both highly uncertain and highly influential, so that the different projections of their future development create very different starting points for the four scenarios (Van ' $t$ Klooster and van Asselt, 2006).

The first factor refers to the type of international integration: will the world move towards global integration or towards increased competition between regional blocks? In this age of rapidly expanding global trade, many see the process of globalisation as a given. According to Keller (2000), globalisation is an irreversible mega-trend which can be expected to have an ever greater impact on the economy and on society in future. Urry (2002) even argues that globalisation and tourism are inextricably connected. However, it is well possible that, far from moving towards global unity, the world will split up into continental blocks, perhaps because of a continued resurgence of Islamism (Brown, 1998). The $9 / 11$ terrorist attacks prove that even a small number of malevolent 'chaos makers' (Faulkner, 2001; Russell and Faulkner, 1999) can change the course of world affairs, particularly in a sector so risk-averse as tourism (González-Herrero and Pratt, 1998).

The second factor refers to the nature of society's guiding rod: will this be materialism and efficiency " or sustainability? This question is also of vital importance for tourism. If costs remain the dominant means for competition, increased consolidation in the tourist industry can be expected to reap economies of scale. While this may lower costs, it may also eliminate product lines and restrict consumer choice (Gartner and Lime, 2000a). If, on the other hand, the baby-boom and later generations put less emphasis on material security and more on quality of life (Teigland, 2000), a very different society may emerge, with 'new tourists' (Poon, 1993) looking for quality and diversity. 
Table 5.1 gives an overview of the relative positions of the four scenarios. Each of the scenarios is further elaborated based on coherent sets of assumptions about future economic growth, population growth, technological developments and other driving forces. Given its focus on global processes, the IPCC framework is based on a coarse segmentation of the world into continental regions. These include Asia, Africa, Latin America, the Middle East, the OECD and the countries in Eastern Europe and the former Soviet Union.

\begin{tabular}{rcc}
\hline & Global integration & Reglonalism \\
\hline Economic emphasis & A1 & A2 \\
Environmental emphasis & $B 1$ & $B 2$ \\
\hline
\end{tabular}

Table 5.1: Characteristics of the IPCC scenario families

The futures that these scenarios sketch imply several structural changes of society, one of them being a transition towards sustainable tourism. Framing the challenges of tourism in terms of transitions can offer levers for policy-making. In the light of the inherent uncertainties, such an approach of transition management emphasises government's role of fostering and guiding innovation processes in society rather than enforcing strict regulation. Section four in this chapter is dedicated to a discussion on how a transition to sustainable tourism could be managed.

\subsection{Looking ahead - the future of tourism}

This section explores the future of global tourism with the IPCC framework. Major issues of interest are the development of tourism in the developing countries, the structure of the tourist industry, and the social and ecological impacts of tourism. For a more extensive treatment, the reader is referred to Amelung et al. (2002).

\subsubsection{THE A1 SCENARIO}

The A1 scenario is a case of rapid and successful economic development, in which average income levels as well as cultures converge. Participation in tourism increases worldwide ${ }_{\text { but }}$ growth rates quickly level off in the developed countries, as a result of saturation. Market saturation increases competition in the tourism industry and the resulting emphasis on cost-efficiency leads to increased attention for economies of scale and thus to market concentration. Mass tourism will continue to thrive, dominated by a few multinationals, but the room for small-scale tourism is limited. Given the high priority given to economic 
goals, resort development takes place in an uncontrolled manner, leading to substantial pressures on social and ecological systems throughout the world.

Demographic and technological developments cause a qualitative shift in tourism demand. Ageing and the decreasing average household size challenge the position of the family as the pivotal market segment, making the market more diffuse. Cheap transport technologies and dense infrastructure networks allow for a sharp increase in long-haul trips. Increased world safety, resulting from strong trade relations add to this trend. The high volume of interregional tourists intensifies the contact between the world regions. This enlarges the scope for the spread of diseases. At the same time, however, vulnerability to these increased health risks decreases as incomes and healthcare improve throughout the world.

In the A1 scenario, participation in tourism increases worldwide, because of the economic and cultural convergence between world regions. Most countries reach the stage of leisure society. With the focus on efficiency and economies of scale, tourism continues to be concentrated in large resorts. Therefore, there are strong economic incentives to follow the traditional destination life cycle, which are not balanced by strong environmental and social policies. In the A1 scenario, there are no signs of a structural change towards sustainable tourism. Economic health and the satisfaction of guest requirements dominate the other goals.

\subsubsection{THE B1 SCENARIO}

The B1 world is characterised by high levels of economic activity and significant and deliberate progress towards international and national income equality. Tourism development is rapid in developing as well as developed countries, resulting in "market saturation in the latter group. In the less competitive B1 world, with its focus on quality and service, this does not harm the tourist industry, because enough financial resources are available to invest in research and development to come up with new concepts and ideas. Even more than today, tourists will be able to arrange their trips according to their own preferences, without having to resort to package deals.

The tourists ${ }^{\prime}$ geographical scope does not increase as dramatically as in the A1 scenario. Environmental concerns and high resource prices put a limit to long haul travelling. Moreover, transport networks are not as extended as in the A1 world. Within each region, however, tourists do spread out, as large resorts lose their market share. At the same time, today's marked seasonality fades, due to the more diffuse tourism demand, caused by ageing and decreasing family size. As a result, the profit potential of the tourist industry increases. Pressures on social and environmental systems are kept to a minimum by implementing 
anticipatory regulations and good planning practices, although the spatial spread of tourism is a cause for concern.

The B1 scenario follows the same path of economic and cultural convergence between world regions as $A 1$. There is a successful transition towards the leisure society in most parts of the world. The heterogeneous and qualityoriented society in B1 indicates that the traditional life cycle pattern of development is unlikely to be dominant; this transition is likely to 'fail' in many instances. Instead, there is room for innovative niche activities. In the B1 scenario there is a globally felt urgency for sustainable development, which fuels the transition towards sustainable tourism in many destinations. However, in spite of these local transitions; the global problems related to tourism mobility and land use remain.

\subsubsection{THE A2 SCENARIO}

In the A2 scenario, the world is divided in regional blocks, each with their respective directions and rates of change. Overall population growth is high and average income growth is low. Moreover, the economic difference between the developing countries and the developed countries remains large. As a result the prospects for tourisin development are dim, especially in the developing world. Worldwide, very limited profit margins and a lack of purchasing power result in a static tourism market with much standardisation and little innovation. In such a world, alternative forms of tourism have little chance of capturing a significant market share. Tourism remains largely beach-based and existing infrastructure and facilities are financially exploited to the maximum in order to avoid new costly investments. Investments in transport networks are also limited, so that tourists on average do not cover large distances.

With the family restored as the centre of social life and high population growth, couples with children will be the dominant market segment. As a result, holidays are forced to coincide with school holidays, so that seasonality remains sharp. The spatial and temporal concentration of tourism put a lot of pressure on the ecological and social systems in the destinations. Due to the low environmental and social priorities, these pressures are not effectively mitigated by policy. In addition, protection of natural areas for tourism purposes is rare. Occasionally, tourism causes infectious diseases to be spread around the world.

In the A2 world, there are large differences between the world regions. In several regions the transition towards the leisure society fails to materialise. In the stagnating market for tourism, the focus is on cutting costs and economies of scale. These provide strong economic forces to push destinations through the traditional life cycle. On the other hand "with the limited concern for social and ecological issues, there is little push towards more sustainable tourism 
development, so this transition fails. On the other hand, tourism's contribution to the global issues of land use and climate change is also relatively limited in this scenario.

\subsubsection{THE B2 SCENARIO}

According to the B2 scenario, income per capita grows at an intermediate rate, and international income differences decrease. At the same time, local inequality is also reduced considerably. The economic requirements for tourism development are met in most countries. Although the tourism market is not booming, growth rates are high enough for the tourist industry to earn a profit and make small-scale investments. In some regions there may be cultural objections against the large-scale introduction of tourism.

Education and welfare programs lead to a much higher life expectancy and to considerable population growth. With the average family size on the increase, the importance of family life is stressed. These trends lead to a tourism market with two major market segments: families with children and pensioners. The seasonality associated with family holidaymaking can be partially or totally offset by the more flexible pensioners.

Both in the developing and in the developed countries, there are shifts from long-distance travelling to short-distance travelling, and from outbound tourism to domestic tourism that reflect the increased concern for environmental and social sustainability. Those who do travel internationally do so in small groups and to small-scale destinations. The emphasis on education, sustainability and quality of life are advantageous for alternative forms of tourism. Local and regional environmental issues, such as the protection of water quality, are high on the agenda. The slow and well-planned development of tourism destinations allows for the implementation of anticipatory policy measures and for adequate enforcement.

In the B2 scenario, successful transitions towards leisure society are limited to a few world regions. In the less developed regions this transition fails. The controlled development of destinations and the limited role of efficiency considerations, leads to the failure of the transition coinciding with the classic destination life cycle. Social and ecological concerns stimulate the transition towards sustainable tourism in the developed regions. Tourism is regionally based, so that destination development is slow in the less developed regions.

The main features of the four scenarios are summarised in Table 5.2. They draw very different pictures of possible future developments in tourism, with different implications for sustainability. From a global environmental perspective, the $A 2$ and $B 2$ scenarios are attractive, because of their low and 
intermediate growth rates. In particular for the $\mathrm{A} 2$ scenario, however, this same feature has dire consequences for the economic and social agendas of many regions in the world. On the level of individual destinations the $B 1$ and $B 2$ scenarios are most promising, because of their strong focus on sustainability considerations. The high growth rates of the B1 scenario, however, raise questions about the sustainability of the overall level of tourism on the global scale. Nowadays eco-tourism already struggles with this paradox. It intends to contribute to local sustainability in individual destinations, but typically results in large transport-related emissions and global sustainability problems, because many eco-tourism destinations are located in distant, exotic places.

\begin{tabular}{|c|c|c|c|}
\hline & Economy & Ecology & Society \\
\hline A1. & $\begin{array}{l}\text { Higl growth } \\
\text { frocus on cost } \\
\text { Harge scale development }\end{array}$ & $\begin{array}{l}\text { Concentrated pressure } \\
\text { allile control over development }\end{array}$ & $\begin{array}{l}\text { High praticipation world wide } \\
\text { Concentrated pressufe } \\
\text { Risk of spreading disease }\end{array}$ \\
\hline$B 1$ & $\begin{array}{l}\text { - High growth } \\
\text { - Focus on quality } \\
\text { - Small-scale development }\end{array}$ & $\begin{array}{l}\text { - Dispersed pressure } \\
\text { - Effective environmental } \\
\text { management }\end{array}$ & $\begin{array}{l}\text { - High participation worlld-wide } \\
\text { - Dispersed pressure }\end{array}$ \\
\hline A2 & 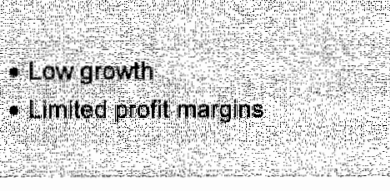 & $\begin{array}{l}\text { Wery concentrated pressure } \\
\text { Lthe control over development }\end{array}$ & $\begin{array}{l}\text { - Low pariticipaton large reglonal } \\
\text { olfferences } \\
\text { Very concentrated pressure } \\
+ \text { High thk of spreading disease }\end{array}$ \\
\hline $\mathrm{B2}$ & $\begin{array}{l}\text { - Intermediate growth } \\
\text { - Slow, well-planned development }\end{array}$ & $\begin{array}{l}\text { - Relatively low pressure } \\
\text { - Effective environmental } \\
\text { management }\end{array}$ & $\begin{array}{l}\text { - Intermediate participation, witt } \\
\text { regional differences } \\
\text { - Low risk of spreading disease }\end{array}$ \\
\hline
\end{tabular}

Table 5.2: Summary of the implications of the IPCC scenarios for tourism

Section 5.4 discusses pathways towards sustainable tourism on the level of individual destinations. Despite its high relevance, global sustainability is not considered, because arguably there is little room for effective measures to manage the overall size of the market for tourism on the global scale, without controversial interventions into the freedom of people to travel and to choose their holiday destinations.

\subsection{Towards sustainable tourism}

The definition of sustainable tourism is subject to considerable debate (e.g. Hunter (1997) and Sharpley (2000)). Müller (1994) expresses the challenge that sustainable tourism poses in terms of five interrelated goals, that must all be met to a satisfactory degree: economic health, subjective well-being of the locals, protection of natural resources, a healthy culture and satisfaction of 
guest requirements. In many places, there may be widespread support for these goals, and it may even be generally accepted that structural changes are necessary to achieve them simultaneously. The nature of the end goal and the preferable pathway towards it, however, are typically very controversial. Perspectives on these issues depend on economic interests, but also on individual knowledge and beliefs.

Sustainable tourism is a contested concept, because it is normative, subjective and ambiguous, just like the overarching concept of sustainable development (Grosskurth and Rotmans, 2005). The contested nature of sustainable tourism, the fuzziness of the long-term aim, the term's connectedness to virtually all elements of a tourist destination, and the difficulty or impossibility of improving any of these elements in isolation, make it a typical subject for transition management.

The Transitional Action Perspective that Rotmans et al. (2001) use is based on a process-oriented philosophy that balances coherence with uncertainty and complexity (see also Chapter 2). It can be summarised in the following five golden rules:

1. Use long-term thinking as the reference for short-term policy making

2. Think in terms of multiple domains, multiple actors, and multiple levels

3. Use learning processes as a steering mechanism

4. Invest in system innovations and system improvements

5. Keep open a large number of options

The first rule implies calis for a long-term transition goal. This transition objective is formulated in a participatory process with stakeholders and is in fact a basket of objectives informed by the visions of those participating. Both objectives and final visions are determined socially, not just by expert scientific knowledge (Rotmans et al., 2001). Several sources of inspiration are available for setting the goals of the transition towards sustainable tourism. For example, the participants at the 1995 World Conference on Sustainable Tourism hold that sustainable tourism development "means that it must be ecologically bearable in the long term, as well as economically viable, and ethically and socially equitable for local communities (World Conference on Sustainable Tourism, 1995)." These criteria can be made operational and serve as a basket of transition objectives by developing a set of indicators for them along with an indicative long-term target value range for each of them.

The actual transition goals that are set are location-specific and dependent on the input from the stakeholders that are involved. For tourism, a typical list of participants includes the tourist industry, public authorities, NGOs, the local population and tourists. Together, they start the transition process by 
formulating the long-term goals of tourism development and the implications for short-term action. Both goals and short-term action are periodically reviewed and adapted if necessary. This flexibility is needed to adjust to the latest insights.

Changes in many domains and by many actors are necessary for a destination's successful transition towards sustainable tourism development. For instance, businesses may have to restructure to reduce pollution, tourists may have to change their behaviour, marketing strategies may have to be redirected towards new target groups and better credit facilities may have to be made available to stimulate local investment.

For all these changes to take place, contributions from many actors, not just government, are needed. Nevertheless, government can and should assume a leading role in transition management. The role of government varies according to the stage in the transition, from inspiring and mobilising actors in the first phases to stimulating learning processes and embedding in the later phases. In a Delphi survey of tourism researchers, the guiding role of government was confirmed. However, a frequently made comment in this survey was "that industry should be the most responsible group, but in the absence of any evidence that the industry has accepted this responsibility and with little faith in the ability of self-regulation to be effective, the national government was most frequently chosen. National government's role was seen as one of stimulating involvement, leading, supporting and guiding the stakeholders and then mediating (Miller, 2001)." It is important to realise, however, that there are clear limits to a government's capability, stemming from its limited control over external factors on the macro level, the constraints imposed by existing structures and arrangements and elusiveness of social processes (Rotmans et al., 2001).

A major challenge for the government as the transition manager is to provide actors with a clear link between the shared long-term vision on sustainable tourism and the actors' daily practice. Often there is a tension between current interests and long-term goals, as is apparent from the Brundtland definition of sustainable development, being "development which meets the needs of the present without compromising the ability of future generations to meet their own needs (World Commission on Environment and Development, 1987)." Therefore, it is essential to take not only the vested interests into consideration, but also new actors with innovative ideas. In the case of tourism, these could be suppliers of small-scale facilities or hotel owners experimenting with environmentally friendly architecture. 
Innovative ideas usually appear in niches at the micro level. In the tourism industry, there is an abundance of such niches, given the large numbers of small enterprises. Therefore, the potential for innovative ideas in the tourism industry is quite large. Governments can stimulate further development of such ideas by initially shielding them from market influence, while at the same time preventing lock-in situations in which room for innovation is very limited. As the set of available options and their effectiveness is unclear, it is advisable to consider a wide range of options (wide playing field) and to experiment with each of the options as a way to act and simultaneously learn more about the contribution the options may make to the realisation of the long-term goals (learning-by-doing and doing-by-learning). Governments can also experiment themselves. They tend to have a major influence in the development of institutions. Some respondents to the earlier mentioned Delphi survey even thought "regulation was the only way in which even government could effect any significant changes (Miller, 2001)."

As it happens with experimentation, most innovative ideas will never have an impact outside their niche, but some will manage to become much more widely known and used. For example, in the Netherlands, a system of quality marks for environmental behaviour has gained momentum and is being adopted by a large share of tour operators in the Netherlands (ANVR, 2001). At the meso or regime level, the quality marks are now recognised as a potential marketing tool. Moreover, as entrepreneurs learn about improvement opportunities, many are motivated to do more, with more innovation and experimentation as a result.

For a meaningful assessment of the usefulness of transition management for attaining sustainable tourism, practical experience with the tool is needed. This first evaluation suggests that tourism management may be a tool to overcome some of the problems related to policy-making in tourism. From the perspective of transition management, the fragmented nature of the tourist industry is an asset rather than a problem. Instead of focusing on the inaccessibility of the sector, tourism management stresses the innovative potential of the large number of niches. By imitation, the whole industry can benefit from innovations made by a few innovators that are stimulated by the government if needed.

Furthermore, a balance is struck between decentralising responsibilities and retaining a central role for government. Facilitated by public authorities, the participating stakeholders set their targets autonomously and use their own creativity to reach them. In addition, the problem of defining "sustainable tourism' is by-passed by allowing for local interpretations of the concept. The long-term goals are not only motivated by scientific insight, but also, and especially, by the stakeholders' views. This increases both the local 'fit' of the measures and their public support. 


\subsection{Conclusions}

Worldwide, tourism has grown enormously over the past few decades, triggered by economic prosperity, political stability, technological developments, and changing life styles. In terms of income and employment generation, tourism is often regarded as one of the most important sectors. Its development is, however, very unevenly distributed across the world, both in terms of tourist flows and revenues. Most of the money earned through tourism flows towards the metropolitan areas in the developed world. Tourism also has mixed impacts on the social and ecological domains, both fostering the conservation and development of cultural and ecological resources, and being an agent in their degradation. So, notwithstanding tourism's potential, there are reasons for concern.

The future of tourism and its impacts was explored with integrated scenarios. To avoid having to develop these scenarios from scratch, the IPCC SRES suite of scenarios was used as a starting point. These scenarios are among the very few that are exploratory and complex, and have a formal design, and thus comply with the requirements of the analysis performed in this chapter. Building upon four different sets of assumptions about globalisation and societal priorities, four radically different future images were sketched. These images ranged from global standardised package tourism to regional small-scale quality-oriented tourism.

The results for sustainability are mixed. From a global environmental perspective, the overall scale of the tourism trade dominates the impact of tourism on all aspects sustainable development. The A2 and B2 scenarios with low or intermediate growth are beneficial for the environment, and less appealing from a business perspective. Scale is not the only factor of importance, however; the impact per tourist also plays a major role. The development of this latter factor is favourable in the B1 and B2 scenarios, which focus on quality and sustainability rather than price and economy. In the worlds depicted by these scenarios, profit margins are higher, income from tourism is more equally distributed, and the ecological impact of tourism is carefully managed.

The scenario analysis shows that the transformation of destinations in the direction of 'B1' or 'B2' types is not to be taken for granted. Even if everybody considers this kind of transformation desirable, a certain amount of management is required to make it happen. The end goal of this transition is a sustainable form of tourism development, but this goal is rather ill defined. To relate this goal back to current practices, a participatory process is needed in which stakeholders translate the long-term goal into targets for the intermediate 
term that can be addressed by short-term action. Since sustainable tourism development is a holistic concept, simultaneous action is required on different levels and by different stakeholders. Quick technological of institutional fixes will not do the job.

The idea of transition management offers a perspective on how government can stimulate appealing transitions or slow down unattractive ones. In this perspective government acts as a societal coach who stimulates and encourages other actors ${ }_{i}$ deducing its indications from a flexible long-term societal goal. This chapter explored the usefulness of transition management for the quest for sustainable tourism. The assessment suggests that with transition management, decision-makers are able to by-pass several difficulties related to policy-making for tourism. In the first place, tourism management offers a way around the scattered nature of the sector by advising to stimulate innovation in several niches and subsequently disseminate the results to the sector as a whole. In the second place, tourism management delegates many responsibilities to individual actors while still retaining a central role for government. And in the third place, with transition management a practical approach towards defining 'sustainable tourism' can be taken, by letting local societal actors set goals in a participatory process. The local fit of the measures taken as well as the public support for them is enhanced by this approach.

\section{References}

ANVR (2001). "Annual Report 2000 (in Dutch)." ANVR (Dutch Assosiation of Tour Operators): De Meern, The Netherlands.

Brown, F. (1998). Tourism Reassessed: Blight or Blessing?, Butterworth-Heinemann: Oxford.

Burns, P. and Holden, A. (1995). Tourism: A New Perspective, Prentice Hall: London.

Faulkner, B. (2001). "The Future Ain't What lt Used to Be." Griffith University: Gold Coast.

Faulkner, B. and Walerio, P. (1995). "An Integrative Approach to Tourism Demand Forecasting." Tourism Management, 16(1): 29-37.

Gartner, W. C. and Lime, D. W. (2000a). "The Big Picture: A Synopsis of Contributions." in: Gartner,

W. C. and Lime, D. W. (eds.) Trends in Outdoor Recreation, Leisure and Tourism, CAB Publishing: Wallingford, UK.

Gartner, W. C. and Lime, D. W. (eds.). (2000b). Trends in Outdoor Recreation, Leisure and Tourism, CABI Publishing: Wallingford ${ }^{U K}$.

Gonzallez-Herrero, A. and Pratt, C. B. (1998). "Marketing Crises in Tourism: Strategies in the United States and Spain." Public Relations Review, 24(1): 83-97

Greeuw, S. C. H., van Asselt, M. B. A., Grosskurth, J., Storms, C. A. M. H., Rijkens-Klomp, N., Rothman, D. S. and Rotmans, J. (2000). "Cloudy Crystal Balls." Environmental issues series 17. European Environment Agency: Copenhagen, Denmark.

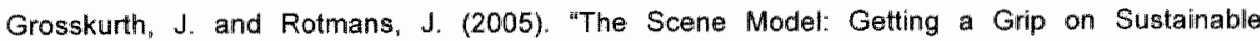
Development in Policy Making." Environment, Development and Sustainability, $7(1): 135-151$. 
Hunter, $\mathrm{C} .(1897)$. "Sustainabie Tourism as an Adaptive Paradigm." Annals of Tourism Research; 24(4): $850-867$.

Keiler, P. F. (2000). "Globalization and Tourism." in: Gartner, W. C and Lime, D. W. (eds.) Trends in Outdoor Recreation, Leisure and Tourism, CABI Publishing: Wallingford, UK.

Martens, P. and Rotmans, J. (eds.). (2002). Transitions in a Globalising World, Swets \& Zeittinger: Lisse.

Mathieson, A. and Wall, G. (1982). Tourism: Economic, Physical and Social Impacts, Longman: London, UK.

Miller, $G$. (2001). "The Development of Indicators for Sustainable Tourism: Results of a Delphi Survey of Tourism Researchers." Tourism Management, 22(4): 351-362.

Moisey R. N. and McCool; S. F. (2001): "Sustainable Tourism in the 21st Century: Lessons from the Past, Challenges to Address." in: McCool, S. F. and Moisey, R. N. (eds.) Tourism; Recreation and Sustainability. CAB\| Publishing: Missoula, Montana, USA.

Míller, H. (1994), "The Thorny Path to Sustainable Tourism Development." Journal of Sustainable Tourisim, 2(3).

Nakicenovic, N., Alcamo, J., Davis, G. and De Vries, B. (2000). "Special Report on Emissions Scenarios." Intergovernmental Panel on Climate Change: Cambridge, United Kingdom.

Pearce D. (1981). Tourist Development, Longman: New York.

Poon, A. (1993). Tourism, Technology and Competitive Strategies, CABl: Wallingford.

Rotmans, J., Kemp. R. and Van Asselt, M. (2001). "Mare Evolution Than Revolution: Transition Management in Public Policy." Foresight, 3(1): 1-17.

Russell, R. and Faulkner, B. (1999). "Movers and Shakers: Chaos Makers in Tourism Development." Tourism Management, 20(4): 411-423.

Sharpley, R. (2000). "Tourism and Sustainable Development: Exploring the Theroretical Divide." Journal of Sustainable Tourism, 8(1): 1-19.

Teigland, J. (2000). "The Effects on Travel and Tourism Demand from Three Mega-Trends: Democratization, Market Ideology and Post-Materialism as Cultural Wave." in: Gartner, W. C. and Lime, D. W. (eds.) Trends in Outdoor Recreation, Leisure and Tourism, CABI Publishing: Wallingford, UK.

UNEP (2002). Global Environment Outlook 3, Earthscan: London.

Urry. J. (2002). The Tourist Gaze, Sage Publications: London.

Van 't Klooster, S. A. and van Asselt, M. B. A. (2006). "Practicing the Scenario-Axes Technique." Futures, 38(4): 15-30.

Van Nolten, P. and Rotmans, J. (2001). "The Future of Scenarios." Scenario \& Strategy Planning. 3(1): 4-8.

Van Notten, P., Rotmans, J., van Asselt, M. B. A. and Rothman, D. (2003), "An Updated Scenario Typology." Futures, 35: 423-443.

Wheeller, B. (1991), "Tourism's Troubled Times: Responsible Tourism Is Not the Answer. "Tourism Management, $12(2)$; $91-96$.

World Commission on Enviranment and Development (1987). "Our Common Future." United Nations: New York.

World Conference on Sustainable Tourism (1995). "Charter for Sustainable Tourism." World Conference on Sustainable Tourism, Lanzarote, Canary Islands, Spain.

WTO (1995). Gobal Tourism Forecasts to the Year 2000 and Beyond, World Tourism Organisation: Madrid, Spain. 


\section{Chapter 6}

Exploring the impacts of climate change on tourism: analyses with tourism climatic indices 


\subsection{Introduction}

Tourism is highly dependent on climate. Climate factors, such as temperature and sunshine, account for a large share of the success of major tourism regions such as the Mediterranean. Climate has been traditionally regarded as a fixed property of these destinations, but this position is changing. The overwhelming consensus of the scientific community is that the global climate is changing. This chapter presents an exploratory analysis of the consequences of climate change for the climatic attractiveness of regions for tourism.

Climate is by no means the only factor that determines international flows of tourists. In some regions and for some tourist activities, climate is more important than for others. In countries with a pleasant climate, such as the Mediterranean, climate acts as an asset that attracts tourists in its own right. In areas with a less reliable climate, climate is not a major reason for tourists to visit that region. Weather patterns do, however, influence the activity patterns of tourists while they are in their holiday destination. Furthermore, beach holidays and outdoor activities in the countryside are more sensitive to climate and weather than indoor activities or city tourism. All in all, climate is a major determinant of tourist flows. Every summer, around 100 million tourists from northern Europe visit the Mediterranean region, mainly or partly to enjoy the sun.

Climate has direct as well as indirect impacts on tourism. It directly influences tourist comfort in destinations, while it indirectly also shapes factors such as landscapes, biodiversity, cultural heritage, and water supply (see Figure 6.1).

Spatial and temporal patterns in tourism are greatly influenced by climate. A large share of international tourism is determined by climate factors, such as temperature and sunshine, which often exhibit considerable seasonal variability. The 'triple-S' of sun, sea, and sand is widely viewed as an important success factor of destinations. This is evidenced by the broad application of climate related images in tourism brochures and other public relations material. The proof for this central position of climate, however, is not merely anecdotal. Statistical analyses by Maddison (2001), Lise and Tol (2002), and Hamilton (2003), and a simulation study by Hamilton, Maddison and Tol (2005) show the relevance of climatic factors as determinants of tourist demand. According to Maddison (2001) the maximum daily temperature should ideally be close to $29.7^{\circ} \mathrm{C}$, while Lise and Tol (2002) estimate the optimal (24 hour) mean daily temperature to be around $21^{\circ} \mathrm{C}$. According to Lise and Tol (2002), people choose a holiday destination with a climate that suits their plans. 


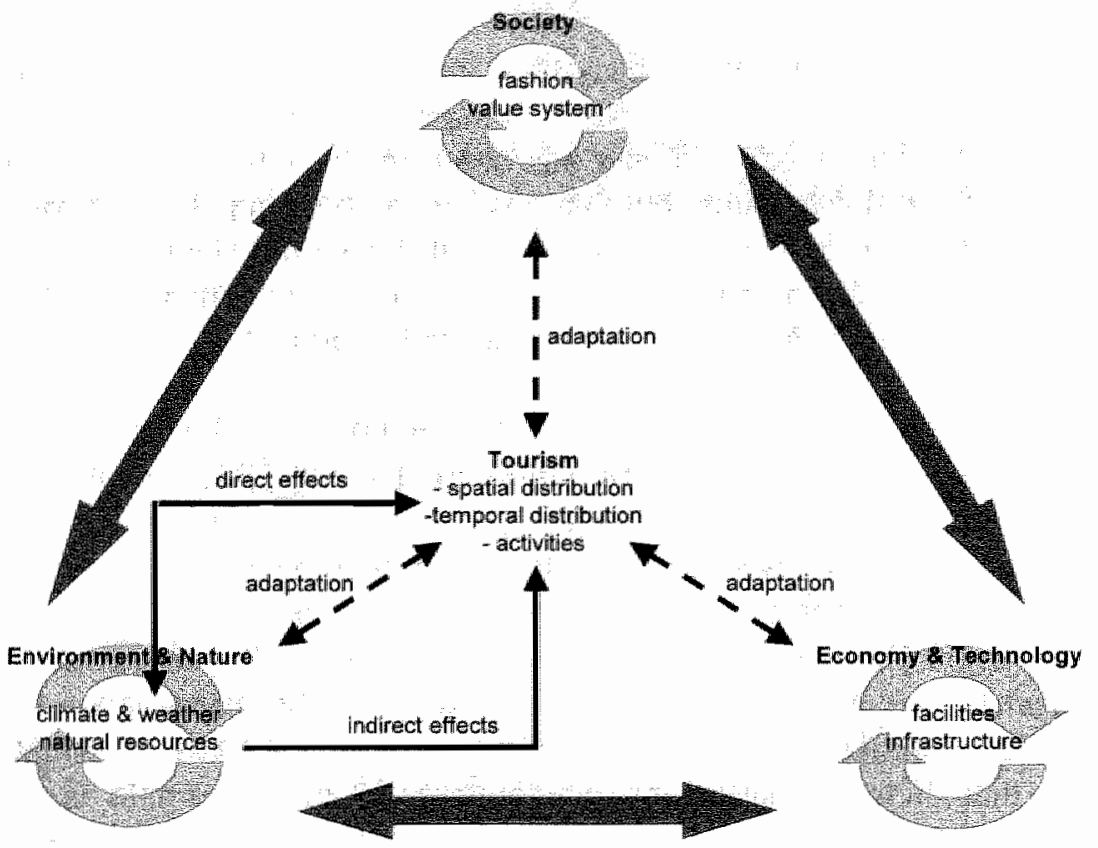

Figure 6.1: Climate change impacts in perspective

Climate has been traditionally regarded as a fixed property of destinations; only climate variability was considered to be of interest. There is now overwhelming evidence, however, that worldwide climate is changing as a result of human activities (IPCC, 2001). Emissions and atmospheric concentrations of $\mathrm{CO}_{2}$ and other greenhouse gases (GHGs) are on the increase, causing increased radiative forcing and higher temperatures around the globe. Based on model simulation runs, the IPCC reports an increase in globally averaged surface temperature of 1.4 to $5.8^{\circ} \mathrm{C}$ over the period 1990 to 2100 ; global mean sea level is projected to rise by 9 to 88 centimetres over the same period, and the frequency of extreme weather events is expected to increase (IPCC, 2001).

Climate change would induce tourists to visit different holiday destinations, or travel in a different season (Lise and Tol, 2002). What is more, many tourist resorts are located in coastal and mountainous zones, which are particularly vulnerable to climate change. It is likely that the simultaneous changes in demand and supply will open up new possibilities for tourism development in some areas and close down options in others.

The systematic study of the effects of climate change on tourism patterns has started only recently, although a collection of more or less isolated studies 
existed beforehand. The effects of climate change on the mountainous regions and the Mediterranean area are among the most studied. Elsasser and Bürki (2002) and Elsasser and Messerli (2001) have assessed the possible changes for the Swiss Alps; Harrison et al. (1999) have done a similar analysis for the Scottish ski industry, while Scott et al. (2001) have explored the implications for the Canadian ski resorts. The most significant impacts on the ski industry are the shortening of the ski season and the upward movement of the snow line.

Perry (2000a; 2000b; 2001) addressed the implications for the Mediterranean region; he concludes that summer increases in summer temperatures may produce an unsuitable climate, a situation aggravated by an increased risk of droughts. Prognoses for the shoulder seasons of spring and autumn are more favourable, however, indicating a potential shift from the summer season towards the shoulder season. Perry's qualitative findings on the Mediterranean are supported by numerical model exercises with the ESCAPE model (Rotmans et al., 1994) that explore the consequences of climate change in Europe. Integrations with the Escape model suggested that the geographical zone with ideal climatic conditions in summer would shift from the Mediterranean towards the North, possibly to the Baltic coast. Such a shift would have profound economic, social and ecological impacts. For example, an estimated 100 million tourists visit the Mediterranean region on an annual basis, spending close to 100 billion dollars (Mather et al., 2005), employing millions of people, and using a lot of water and energy.

Agnew and Viner (2001) explored the impacts of climate change on a range of different destinations; this was the first definitive attempt to examine the multisectoral and global changes in tourism flows as a result for climate change. Viner and Amelung (2003) report on the wider issues that surround the interactions of climate change with tourism and the environment. Mather et al. (2005) take this approach further and examine the policy responses required to address the impacts of climate change on tourism, and tourism on the climate system.

Hamilton et al. (2005) introduce climate factors into tourist demand modelling, which is traditionally focused on price and distance factors. They developed a model for estimating bilateral tourist flows between all countries in the world. Apart from population, income, country size and several other variables, their model included temperature as a determinant for the size and direction of tourist flows. With this model, Hamilton et al. analysed the effects of climate change on tourism patterns. This line of research has so far mainly focused on temperature and disregarded factors such as precipitation and sunshine, which are also of obvious importance for tourism. What is more, the approach has not properly addressed the spatial and temporal concentration of tourism. The issue of 
concentration, which is central to tourism, calls for analyses with short timetrames and small areas, whereas rellable datasets for travel patterns are avallable only on a country-by-country level and on an annual basis. Although largely springing from a lack of reliable data, these shortcomings cast doubt on the relevance and reliability of the statistical results.

In sharp contrast with tourism data, climatological data are avallable on the more disaggregated spatial and temporal levels that are required. Analyses with tourism climatic indices (TCls) take advantage of this. TCls, such as the ones devised by Meczkowski (1985) and Hatch (1984; 1988), are composed of ratings for a number of climate variables that are relevant for outdoor tourism activities, and aim to express the overall suitability of a region's climate for tourism. In part because of data limitations, TCl performance in predicting visitation levels has not yet been tested rigorously on a global scale. TCis have, however, been compared with actual tourist demand for several individual tourist destinations. The reader is referred to Scott and McBoyle (2001) for 17 North American cities, to Rotmans et al. (1994) for the Spanish destinations of Gerona and Majorca, and to this thesis for the Balearics. All three studies report a strong correlation between TCl scores and tourist demand. Although this body of evidence is not conclusive, the positive results do support the hypothesis used in this chapter that TCls can be effective indicators for the climatic attractiveness of tourist destinations.

The primary aim of this chapter is to describe a methodology for applying the concept of $\mathrm{TCl}$ to the exploratory study of climate change impacts on tourism patterns. The methodology is elaborated for the TCl developed by Mieczkowski (1985), but it can also be used with other TCls such as the 'climate code' devised by Hatch (1988). This chapter describes the process that was followed to transform raw climate data into $\mathrm{TCl}$ scores, and details a range of techniques for presenting results.

This chapter is organised as follows. Section two introduces the concept of the "tourism climatic index", addressing key issues such as factors included and weighting. Section three elaborates on the analysis and the data used, followed by a presentation of the results in section four. Section five combines a discussion of the results with the key conclusions and policy recommendations.

\subsection{Tourism climatic indices}

Tourism climatic indices have evolved from general knowledge about the influence of climatic conditions on the physical well being of humans. In the 1960 s and 1970 s systematic research in this field yielded important insights, 
ranging from preferred temperatures, and the role of relative humidity to the role of wind. It should be noted that the appreciation of climatic conditions is dependent on a host of non-climatic factors, such as the level of activity, clothing, and genetic set-up (Matzarakis, 2001a).

Hatch $(1984 ; 1988)$ and Mieczkowski $(1985)$ are among the very few who applied the general findings about human comfort to the specific activities related to recreation and tourism. Mieczkowski devised a tourism climatic index that was composed of five sub-indices, describing daytime thermal comfort $\left(T_{h} C_{D T}\right)$, daily thermal comfort $\left(T_{h} C_{D L}\right.$ ), precipitation (Prec), sunshine (Sun), and wind. For each of the sub-indices, Mieczkowski considered several alternative indicators, and several alternative ways of translating these indicators into ratings, choosing solutions that were both theoretically defensible and practically feasible. Mieczkowski proposed the following equation for calculating the TCl:

$$
T C l=2 \cdot\left(4 \cdot T h C_{D T}+T h C_{D L}+2 \cdot S u n+2 \cdot P r e C+\text { Wind }\right)
$$

All sub-indices are calculated with mean monthly values, and can attain a maximum value of 5 . The thermal comfort indices are based on effective temperature, which is a measure of temperature that takes the effect of relative humidity into account. Information on short and long wave radiation is not included in the thermal comfort indices, although the latest contributions to biometeorological literature (Matzarakis, 2001a; 2001b; Skinner and De Dear, 2001) state that this type of information is essential for deriving modern thermal indices. It is, however, not generally available in observed climate datasets. The wind sub-index combines information about wind speed and temperature. The other indices are based on single variables and reflect either the empirical findings of physiological research or qualitative assessments of tourist preferences. A crucial issue is the fact that tourists' appreciation of climatic conditions depends on activity levels. Beach holidays, for example, require other climatic conditions than biking trips. Mieczkowski took light tourist activities as the point of reference for his rating system, and his example is followed here. The rating scheme is detailed in Table 6.1. For a detailed description of the set of variables, see Mieczkowski (1985).

Even though the weights used in equation 6.1 do have a basis in scientific knowledge, they contain a fair amount of subjective judgement. In Mieczkowski's TCl, the highest weight is given to the daytime comfort index to reflect the fact that tourists are generally most active during the day, and that temperature is the key factor determining climate fitness. Sunshine and precipitation are given the second-highest weights, followed by daily thermal comfort and wind speed. After summing the weighted individual components, 
the result is multiplied by two; so that the maximum $\mathrm{TCl}$ score is 100 . The minimum $\mathrm{TCl}$ score is -30 , which is attained when both $T_{\mathrm{C}} \mathrm{C}_{\mathrm{DT}}$ and $T \mathrm{TC}_{\mathrm{DL}}$ adopt their minimum score of -3 .

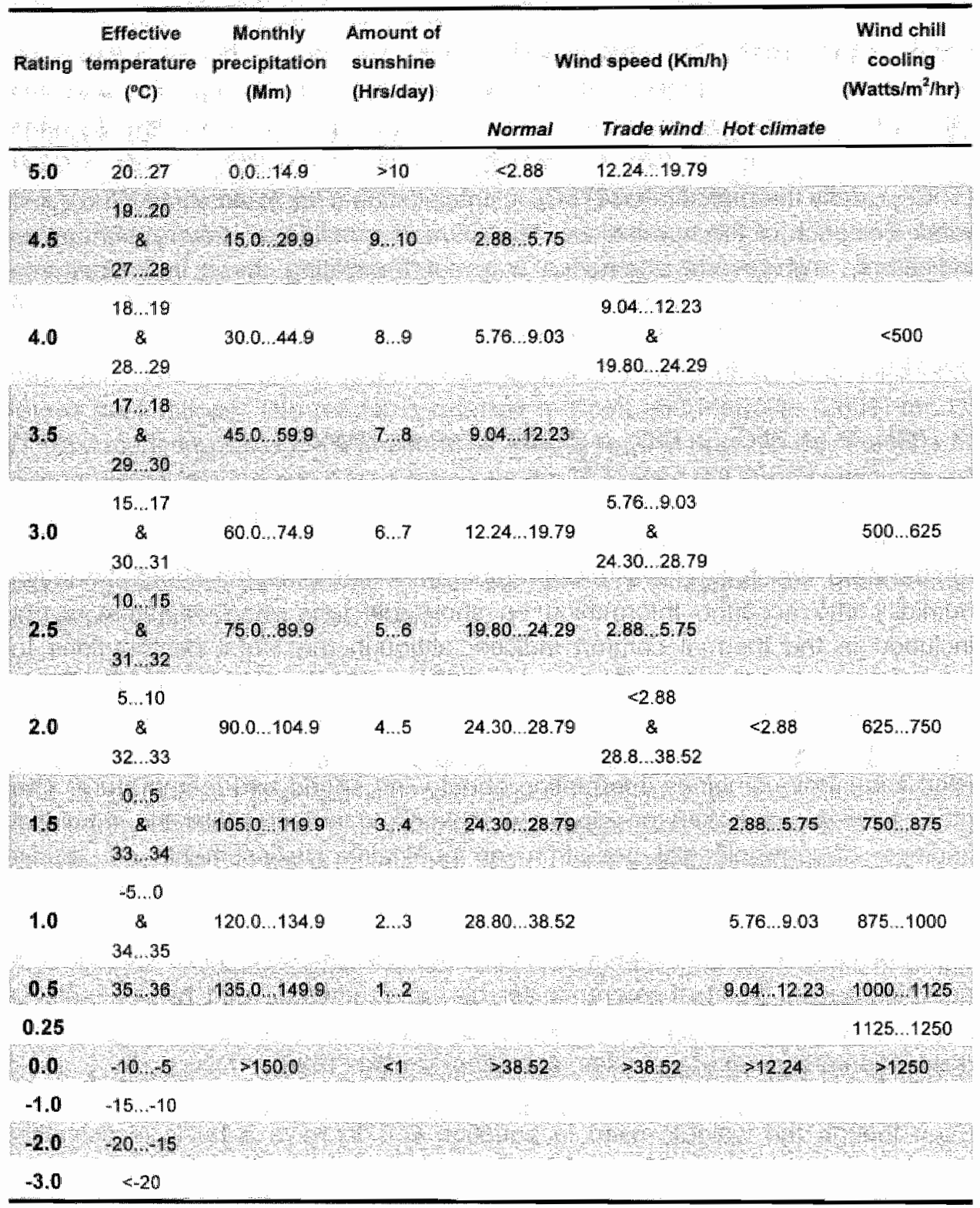

Table 6.1: Mieczkowski's rating scheme

Source: Mieczkowskil (1985)

The 'climate code' devised by Hatch (1988) is based on similar variables but the weighting scheme differs markedly from the one used by Mieczkowski. It 
comprises a comfort index and a discomfort index. The six elements of the comfort index are: mean minimum temperature, mean maximum temperature, total precipitation, days with $>0.1 \mathrm{~mm}$ precipitation, hours of sunshine per day, and percentage of sunshine of possible. In contrast to Mieczkowski's equation, all elements have an equal weight. Since Hatch's rating schemes for the comfort index are all linear, a discomfort index must be introduced to reflect the existence of an optimum temperature. It assumes a nonzero value if either the average temperature exceeds 21 degrees or relative humidity exceeds 70 percent. The overall climate code is obtained by subtracting the discomfort index from the comfort index.

Validating the performance of TCls as a predictor for tourist demand is troublesome. First and foremost, climatic conditions are by no means the only determinant of tourist patterns; rather, there is an amalgam of factors involved, including price, distance, landscapes, income, and cultural heritage. Furthermore, it is not so much the climatic conditions per se that are important, but the conditions relative to those of competing areas (2005). All significant tourist flows and destinations should therefore be studied in an integrated manner, rather than in isolation. This puts strong requirements on the completeness and consistency of datasets.

In practice, the resolutions of the tourism data and the climate data are very different. Climate datasets are typically grid-based and have a temporal resolution of a day, or a month. Tourism datasets are typically country-based and have a resolution of a year. More detailed datasets are available for a number of individual destinations or even countries, but no complete and consistent dataset can be compiled with these. All attempts to validate the $\mathrm{TCl}$ or experiment with it have therefore concentrated on individual sites or destinations.

Rotmans et al. (1994) report on Hatch's 'climate codes' for the two Spanish resorts of Gerona and Majorca. In both resorts, the tourist high season coincides with a climate code exceeding 70 . For Gerona, tourist activities are heavily concentrated in July and August with more than $50 \%$ of annual arrivals occurring in these months. In Majorca, the high season is spread out across five months (May to September), with more than $75 \%$ of arrivals taking place in those months. Outside of this period, both climate code and visitation levels are sharply lower. Scott et al. (2001) compared the Mieczkowski TCl with tourist demand in 17 North American cities. In the absence of arrival data on the required spatial and temporal resolutions, $\mathrm{TCl}$ scores were compared with hotel prices, which were assumed to increase with higher demand. The accommodation cost curves were found to resemble the TCl curves for each of the cities examined. Amelung and Viner (in press) revisited Majorca and 
compared its (Mieczkowski-based) TCl curve with the number of nights spent on Majorca by foreigners. A striking result was that more than $85 \%$ of the annual total of nights spent were accounted for by those six months in which TCl values were in excess of 70 points in the years 1999-2003.

Mieczkowski's and Hatch's TCls were originally devised to assess the quality of existing climates for tourist purposes. Climate change research has nevertheless opened up new fields of application for $\mathrm{TCl}$ analyses. This chapter details how the Mieczkowski TCl can be used to explore the impacts of climate change on climate resources for tourism around the world.

\subsection{Data and Methods}

The use of a numerical index for analyses on a global scale imposes stringent requirements on the dataset: it needs to have global coverage for all constituting variables, and this must hold for both the present and the future. These requirements were met by combining two datasets: the $C R U C L 1.0$ historical dataset, containing 0.5 degree 1961-1990 mean monthly data, assembled by the Climatic Research Unit, University of East Anglia, Norwich, UK (New et al., 1999); and results from a number of integrations performed with HadCM3 (a coupled atmosphere-ocean global climate modell) forced with a range of SRES scenarios (Johns et al., 2003).

The CRU CL 1.0 grid-based dataset contains a dataset of 1961-1990 climatological normals, which were produced by numerous weather stations around the world, numbering between 3615 for wind speed and 19800 for precipitation (New et al., 1999). The station data were interpolated to obtain a $0.5^{\circ}$ lat $\times 0.5^{\circ}$ long grid-based dataset, covering the entire landmass of the earth except for Antarctica; ocean space is not included. Data for all necessary variables could be derived from the dataset, either directly or after some manipulation of raw data.

The variables of mean temperature, maximum temperature, vapour pressure, precipitation and wind could be used after minor transformations. The calculation of the number of sunshine hours required some more work. This number is equal to the maximum possible number of sunshine hours multiplied by the fraction of the time that the sun is indeed shining bright, which is inversely related to the percentage of cloud cover as follows (Monteith, 1965):

$$
\text { Sunh }=\frac{\text { Sunh }_{\max } \cdot(90-\text { Cloud })}{90}
$$


The maximum number of hours of sunshine is directly related to the solar cycle and is place and time dependent; it is determined by latitude and by the amount of time elapsed since the winter solstice in the Northern Hemisphere (December 21).

$$
\text { Sunh }_{\max }=\frac{24 \cdot \arccos (A)}{\pi},-1 \leq A \leq 1
$$

in which

$$
A=\tan \left(\frac{\pi \cdot \text { Latitude }}{180}\right) \cdot \tan \left(\frac{\pi \cdot \text { AxialTilt }}{180}\right) \cdot \cos \left(\frac{2 \cdot \pi \cdot \text { Day }}{\text { DaysPerYear }}\right)
$$

The axial tilt of the year (AxialTilt) and the number of days in a year (DaysPerYear) are constants, taking on the values of 23.5 degrees and 365.25 days respectively.

To check the correctness of the data and the computer code, our dataset was used to replicate the calculations underlying the map of historical TCl scores for the Month of January that Mieczkowski (1985) published in his chapter. The maps show considerable overlap in large parts of the world, but there are some significant differences as well, in particular in Africa, Asia and South America. These can largely be explained by the differences in the datasets used. Mieczkowski used 453 weather stations, while the CRU dataset was constructed on observations from up to 19800 stations. This explains why some of the major differences can be found in the areas that have the poorest coverage by weather stations, such as Asia and Central Africa. A second source of discrepancies is that Mieczkowski must have used an older dataset than the 1961-1990 dataset used by CRU, although the author does not mention the exact period that the dataset refers to.

Future climatic conditions cannot be predicted with any degree of certainty. Future socio-economic and technological developments will determine to a large extent the amount of human-induced emissions of greenhouse gases. The Intergovernmental Panel on Climate Change (IPCC) undertook an exploration of the possible changes in socio-economic conditions and population (IPCC, 2001), which resulted in a range of plausible scenarios (known as the SRES scenarios). From these, GHG emissions and atmospheric concentrations of these gases could be estimated, which in turn have been used to explore the response of the climate system. The dataset of future climatic states was based on an integration of the Hadley Centre's HadCM3 model forced with the four standard SRES emissions scenarios: A1F, A2A, B1A, and B2A.

The HadCM 3 model produces gridded data with a spatial resolution of $2.5^{\circ}$ latitude $\times 3.75^{\circ}$ longitude, which is significantly coarser than that of the CRU 1.0 
dataset. The HadCM3 simulated dataset consists of monthly normals for four time slices: 1961-1990;2010-2039; 2040-2069; and 2070-2099. For reasons of conciseness, these periods will be referred to as "the 1970s", "the 2020s', 'the $2050 \mathrm{~s}^{\prime}$, and 'the 2080s'. Data belonging to these time slices were available for a number of scenarios, of which the four standard SRES scenarios were used in the analysis. All variables that were needed for the analysis were available from the HadCM 3 dataset or could be calculated from it. Unlike the CRU 1.0 dataset, the HadCM3 dataset does not include vapour pressure. It can, however, be calculated from temperature and relative humidity data, using the equation:

$$
V_{a p}=\frac{R H \cdot V_{a p}}{100}
$$

In which saturated vapour pressure is a function of temperature that is described by the Clausius-Clapeyron equation:

$$
V_{\text {ap }}=6.108 \cdot e^{\frac{17.27 T}{237.3+T}}
$$

\subsubsection{CALCULATION OF CHANGES AND CONSTRUCTION OF PROJECTIONS}

Climate models are known to be better at simulating change than at simulating climatic conditions in an absolute sense. The simulated datasets were therefore used to calculate changes, while the observed baseline dataset was used as a reliable starting point. As a first step, the model projections were reduced to differentials by subtracting the simulated baseline states from the simulated future states, and these changes were then added to the observed baseline state. For temperature, absolute differentials were used, while for the other variables relative changes were used, conforming to common practice (Hulme et al., 2002). This procedure has the following rationale: if simulations indicate large negative changes for a certain area and the observed initial value is relatively small, adding the absolute differentials could yield negative results, which is impossible (e.g. negative amounts of precipitation). A drawback of using relative changes, however, is that these can be very large if the initial simulated value is zero or close to zero. In such cases, meaningless results may be produced if observed initial values are not close to zero. In our analyses increases are therefore limited to a maximum of $100 \%$.

Some difficulties arise because the resolutions of the CRU and the HadCM3 datasets are different: $0.5^{\circ} \times 0.5^{\circ}$ degree versus $2.5^{\circ} \times 3.75^{\circ}$ respectively. The HadCM 3 grid consists of 73 rows and 96 columns. When combining the projected changes with the observed data in each of the cells in the CRU grid, these cells may either correspond with one of the HadCM3 cells or with an intersection of two or four HadCM 3 cells. Figure 6.2 gives an overview of the possibilities. 


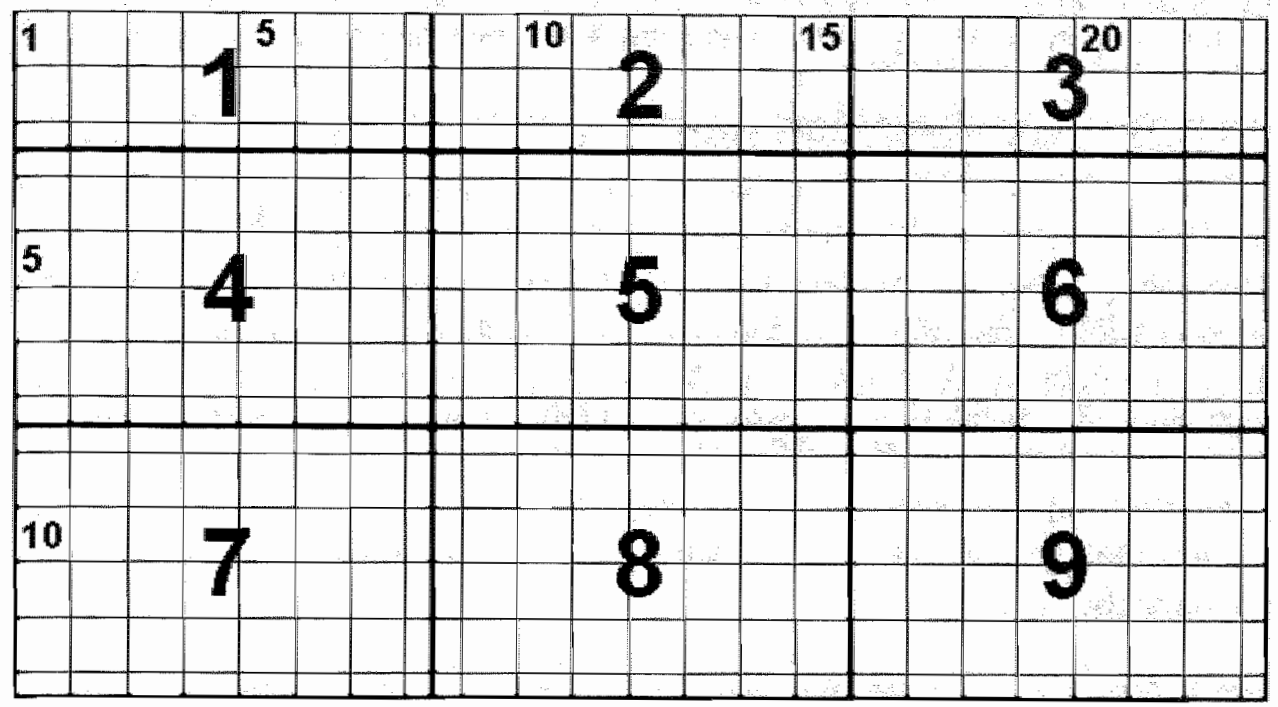

Figure 6.2: Combining grids

Most of the CRU cells (in black) correspond with only one of the HadCM3 cells (in red). For example, this is the case for cell $(5,10)$ that falls plainly within HadCM3 cell $\mathrm{nr} 5$. If this latter cell is a land cell, its content is used to calculate the projection as explained before. If, however, the cell is a sea cell, another procedure is used, because apparently the CRU cell is a land cell that disappeared in the HadCM3 grid due to the coarser resolution. Since many climatological phenomena are very different over land and over sea, it would be misleading to use the sea dynamics from the HadCM3 model for projections of the future state of a land cell in the CRU grid. Therefore the values of land cells in the immediate neighbourhood of the HadCM3 sea cell were used in such cases. In the case of cell $(5,10)$ the average would be taken of the land cells among the eight surrounding cells at a distance of less than one cell - i.e. cells 1 to 9 . If all these cells were sea, cell $(5,10)$ would be counted as sea in the projections.

Some other cells are right on the intersection of either two HadCM3 rows or two HadCM3 columns, e.g. $(3,12)$ and $(5,8)$ respectively. If either or both of the two HadCM 3 cells were land, the average value of the land cells was used. Otherwise, the average was taken of the land cells at a distance of less than one cell. In the case of $(3,12)$ these would be cells 1 to 6 . In the case of cell $(5$, 8) these would be cells $1,2,4,5,7$, and 8 . If none of these cells were land, the CRU cell was treated as a sea cell. For those cells on the intersections of two HadCM3 rows and two HadCM3 columns, the logic would be similar. For cell (3, 
8), for example, the average value of the land cells in the set $(1,2,4,5)$ would be taken. In the absence of land cells, the CRU cell was treated as a sea cell.

\subsubsection{TRANSFORMATION INTO RATINGS}

The database containing the projections of the basic variables form the basis for determining the ratings of the individual elements of the tourism climatic index. The rating schemes as described by Mieczkowski (1985) were used. The schemes for precipitation and sunshine are straightforward, while the schemes for the thermal comfort indices and the wind index are a bit more complicated to implement: For wind, Mieczkwoski devised four different regimes, depending on temperature, of which three are straightforward. The fourth one "the relationship between wind speed and tourist comfort in the wind chill regime, was only represented graphically, with tourist comfort depending on the cooling rate produced by the wind.

The graphical representation of wind chill used by Mieczkowski matches the old formulas used in the United States and Canada. Prior to October 2001, the weather services in these countries used the Siple-Passel wind chill equation, based on work done by Siple and Passel (1945) in Antarctica in the 1940s. The new wind chill index (Meteorological Service of Canada, 2003) makes use of scientific advances to provide a more accurate and useful measure of how cold it feels when it is windy. The difference between the two indices is very significant for extremely low temperatures, while it is much less prominent for temperatures around zero degrees Celsius or above. Since areas with very low temperatures are of little relevance here anyway, and the old index is much easier to process, the original formulation is used here. Wind chill depends on the amount of heat loss $(\mathrm{H})$, expressed in Watts per square meter, which is a function of ambient temperature $(T)$ in ${ }^{\circ} \mathrm{C}$, and wind speed $(W)$ in $\mathrm{km} / \mathrm{h}$ :

$$
H=(12.15+6.13 \cdot \sqrt{W}-0.32 \cdot W) \cdot(33-T)
$$

In his original description of the tourist comfort index, Mieczkowksi (1985) used the concept of Effective Temperature as the basis of his thermal comfort indices. This concept expresses the intensifying effect of humidity on the human sensation of temperature. Currently, the competing and more recent concept of Apparent Temperature, developed by Steadman (1984), is more commonly used. Its dependence on temperature and relative humidity can be expressed in mathematical terms, which is an important advantage over Effective Temperature, for which this dependence could only be represented graphically.

In their recent study of tourist comfort indices in North America, Scott and McBoyle (2001) chose to replace Effective Temperature with Apparent Temperature. The basic model runs underlying this chapter were done with the 
Apparent Temperature measure, but the results were compared to Effective Temperature results as a matter of sensitivity analysis.

Steadman (1984) defined apparent temperature as follows:

$$
A=-1.3+0.92 T+2.2 e
$$

where $A$ is apparent temperature $\left({ }^{\circ} \mathrm{C}\right), T$ is ambient air temperature $\left({ }^{\circ} \mathrm{C}\right)$ and $e$ is water vapour pressure $(\mathrm{kPa})$. The same scheme that Mieczkowski's (1985) developed for mapping Effective Temperature to comfort rates was used here for mapping Apparent Temperature to comfort rates.

To analyse seasonal TCl patterns, a classification of $\mathrm{TCl}$ distributions is used that is adapted from the one used by Scott and McBoyle (2001). Table 6.2 shows the details.

\begin{tabular}{|c|c|c|c|c|c|}
\hline & All months & Spring & Summer & Autumn & Winter \\
\hline Optimal & $\geq 80$ & - & - & - & - \\
\hline Poor & $\leq 40$ & - & - & - & - \\
\hline Summer Peak & - & - & $\begin{array}{c}\text { 1st highest } \\
\mathrm{TCl}\end{array}$ & - & - \\
\hline Winter Peak & - & - & - & - & $\begin{array}{l}\text { 1st highest } \\
\mathrm{TCl}\end{array}$ \\
\hline Bimodal & - & $\begin{array}{c}\text { 1st or } 2 \text { nd } \\
\text { highest } \mathrm{TCl}\end{array}$ & - & $\begin{array}{l}1 \text { st or } 2 \text { nd } \\
\text { thighest } \mathrm{TCl}\end{array}$ & - \\
\hline $\begin{array}{l}\text { Dry season } \\
\text { Peak }\end{array}$ & - & $\begin{array}{l}\text { 1st highest } \\
\text { TCl (or } \\
\text { Autumn) }\end{array}$ & - & $\begin{array}{c}\text { 1st highest } \\
\text { TCl (or } \\
\text { Spring) }\end{array}$ & - \\
\hline $\begin{array}{l}\text { Spring Peak } \\
\text { Autumn Peak }\end{array}$ & $4+$ & $\begin{array}{l}\text { 1st highest } \\
\text { TCl} \\
\text { 3rd or } 4 \text { th } \\
\text { highest TCl }\end{array}$ & 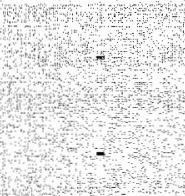 & $\begin{array}{c}\text { 3rd or } 4 \mathrm{hh} \\
\text { highest TCl } \\
\text { 1st highest } \\
\text { TCl }\end{array}$ & \\
\hline
\end{tabular}

Table 6.2: TCl distributions

Source: Adapted from Scott and McBoyle (2001)

A distribution qualifies as "optimal" if all monthly ratings are 80 or higher; it qualifies as "poor' if all monthly ratings are 40 or lower. If these conditions do not apply, there are four other options. The summer and winter peak distributions apply if the highest $\mathrm{TCl}$ ratings occur in summer or winter respectively. If the scores in spring and autumn are higher than in both summer and winter, the bimodal distribution applies. The 'dry season peak" is somewhat ambiguous, because the dry season can coincide with either the spring or the autumn 
season. Therefore, in our analyses, the 'dry season peak' distribution is split up into spring peak and autumn peak. In a spring peak (autumn peak) distribution, the highest TCl scores occur in the spring (autumn) season, with autumn (spring) not coming in second place; otherwise the bimodal distribution would apply.

Note that the relationship between months and seasons is adjusted for the hemisphere that is considered. For example: in the northern hemisphere, the spring season is taken to encompass the months of March April and May (MAM), while in the southern hemisphere, it is taken to encompass the months of September, October and November (SON).

\subsection{Results}

With the newly formed TCI dataset the following analyses were performed. First of all, the historical TCl patterns for each of the four seasons as well as the seasonality patterns were composed and anallysed. Subsequently, the future $\mathrm{TCl}$ and seasonality patterns were explored, with a focus on the changes with respect to the historical case. For several individual cells, the distribution of TCl scores over the year was studied in some more detail to track any shifts in seasonality that climate change may incur on tourist destinations.

\subsubsection{OBSERVED TCI PATTERNS}

For most regions in the world, there are significant differences in climatic conditions for tourism between the seasons. Only very few regions enjoy an excellent climate with scores of 80 points or more year-round. To analyse the seasonal differences, three-month averages were calculated for the four seasons: March, April, May (MAM; Spring in the Northern Hemisphere, Autumn in the Southern Hemisphere), June, July and August (JJA), September, October, November (SON), and December, January, February (DJF).

For the tropics and subtropics, where the interplay between temperature and humidity is strongest, results yielded with the effective temperature measure are generally higher than those yielded with the apparent temperature measure. Nevertheless, both measures turned out to generate very similar patterns.

MAM conditions are good in the south-western United States, in Mexico, eastern Argentine, southern Africa, northern Africa, Arabia, Pakistan "and Australia. Conditions are much less favourable around the equator, and in the northern parts of Europe and North America. In the important tourist 
destinations of the northern Mediterranean and the Caribbean, conditions are generally good or acceptable.

In JJA, the areas with good climatic conditions are situated closer to the poles. In North America, conditions are best in the north-western United States and in southern Canada, while in South-America, climatic conditions are very favourable in Paraguay, northern Argentine and southern Brasil. In Africa, optimal conditions are limited to a narrow coastal zone in the north, while covering most of the continent south of the Equator. Conditions are very favourable in the northern part of Australia as well. Almost all of Europe, except for the UK and Scandinavia is characterised by good or even excellent climatic conditions. This area extends as far eastwards as the borders with China.

Hatch's climate code yields much poorer results for North Asia, Europe and North America. According to this code, pleasant conditions are limited to California in North America, and to the northern Mediterranean in Europe. In Asia, there are significant differences to the east of the Caspian Sea, where TCl scores are consistently higher than scores on the climate code. The greater weight of precipitation in the climate code appears to be the key factor in explaining these differences.

The patterns in SON are very similar indeed to those in MAM. The optimal zone in southern Africa is a bit smaller, but the zones with poor scores in Africa and South America are considerably more restricted as well. For SON, the general patterns produced by the Hatch Index support these observations.

In DJF, two clear belts of optimal conditions can be identified that run around the entire globe. The first one runs from Central America through North Africa, Arabia, India and China. India stands out in particular, as its Season DJF scores are very high, while they are much lower in the other three seasons. The second belt of optimal climate is much narrower. It runs from the southern part of Argentine, through the southern tip of Africa and through southern Australia.

\subsubsection{CURRENT SEASONALITY PATTERNS}

There are virtually no regions with an optimal climate (i.e. exceeding 80 , see Table 6.2); in fact, their numbers are so few that they are not distinguishable on the map. Large parts of Indonesia and Greenland, as well as significant sections of the Amazonian are rated 'poor', either because of a combination of very high temperature and high humidity levels, or because of very low temperatures. The remaining parts of North America, Europe and North Asia are characterised almost entirely by a summer peak distribution. Thermal comfort is the main factor here, with pleasant temperatures in summer and lower temperatures in the other seasons. Interestingly, analyses based on 
Hatch's climate code classify more areas as "poor', including large parts of the Canadian state of Quebec, Iceland, Northern Ireland and Scotland. The summer peak distribution is much less common in the southern hemisphere, because it contains much less land at high latitudes (i.e. close to the South Pole).

Large parts of Central America, Africa, Arabia, India, southern China and northern Australia have a winter peak distribution, with temperatures and humidity decreasing sufficiently in winter as to become pleasant. The remaining three types of distribution are located between the summer peak areas and the winter peak areas. The bimodal distribution is by far the most important of these three. It is found in the southern states of the USA and in northern Mexico, in North Africa and the Middle East, in East China, and in parts of Argentina, South Africa and Australia. In these areas, summer is too hot for comfort, whereas the so-called shoulder seasons are better suited for tourism. Dry season distributions are not very common. Spring peak distributions occur in small areas in Mexico, North Africa, China and Australia, while the only major area with an autumn peak distribution can be found in the South America, around French Guinea. Simulations with Hatch's climate code produce much larger and more widespread spring and autumn peak distributions. East and west China, for example, are classified as autumn peak areas, while parts of Alaska and the Arctic part of Canada are classified as spring peak areas. For most other areas, Mieczkowski's $\mathrm{TCl}$ and Hatch's climate code yield similar results.

\subsubsection{FUTURE PATTERNS}

In all scenarios, the pattern of seasonal TCI distributions changes markedlly. The summer peak distribution, being the closest to the poles already, loses ground in many places, while the other types of distributions expand their territories towards the poles. The direction of these shifts is very similar for all scenarios, the main distinction being the different speeds. Figure 6.3 represents the development of the numbers of cells falling into either the summer peak (SP) or bimodal (BM) type of distribution. Up to the 2020s, the differences between the scenarios are relatively small, but these increase dramatically from the 2050 s onwards. The $A$ scenarios entail much more rapid change than the $B$ scenarios, with the A1F scenario representing the highest pace of change considered here. In the A1F world, $26 \%$ of the current summer peak area will have adopted a different $\mathrm{TCl}$ distribution by the 2080 s, versus $12 \%$ in the B1 world. Similarly, the bimodal distribution will dominate $47 \%$ more terrain in the 2080 s in the A1F world against $12 \%$ more in the B1 world. Bearing these differences in mind, and being unable to show results for all four scenarios in this chapter, the focus in the rest of the chapter will be on the A1F scenario. First of all, this 'maximum change' scenario is helpful in clearly illustrating the 
potential impact of climate change on climatic resources for tourism around the world Secondly, while the A1F may be a scenario of rapid change, it does resemble the emission pathway that the global community is following today.

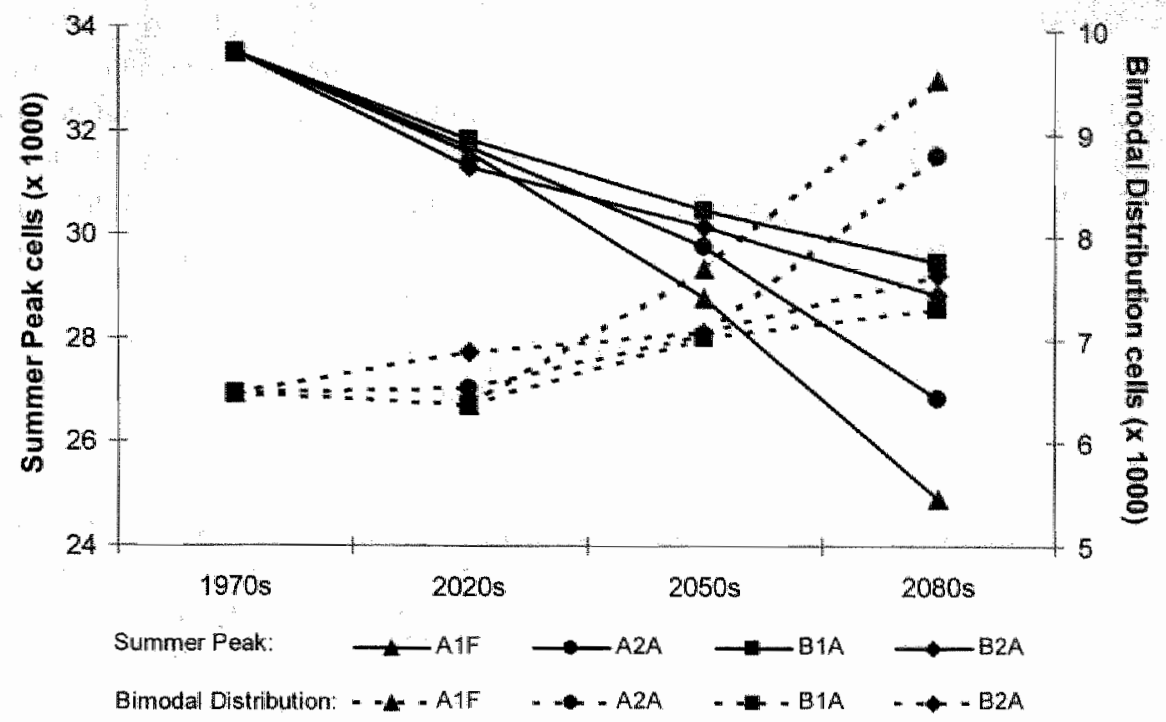

Figure 6.3: Development of the frequency of summer peak and bimcdal distribution cells according to the four standard scenarios

In the A1F world, the zones that qualify as 'poor' expand markedly in the tropics: the Amazon basin, central Africa and Indonesia. In the 2080s, the largest Indonesian islands all get rated as 'poor'. The island of Java, however, and also the island of Bali, remain winter peak territory, which is an important remark given the high level of tourist activities on these islands. Huge changes also take place in Eurasia and North America, with the zone of bimodal distribution gaining ground from the summer peak area. Virtually the entire Mediterranean basin will be characterised by a bimodal regime, with very hot summers and pleasant spring and autumn seasons. In North America, the bimodal regime also moves northwards, covering most of the United States and southern Canada by the end of the century.

On average, the annual mean $\mathrm{TCl}$ score decreases by almost 1.4 points (3\%) between the 1970 s and the 2080 s in the A1F world. While this may seem a relatively small change, the reader should keep in mind that this is the net effect of favourable and unfavourable effects across the globe. The largest positive change is projected for an area in the Altiplano region on the border between Bolivia and Chile, where the annual mean $\mathrm{TCl}$ increases by 23 points from 53 to 76 , with the best month (August) reaching 85 in the 2080s (up from 59). The largest negative change is projected for an area in the east of the Democratic 
Republic of the Congo, which on average loses 34 points, from 66 to 32 , with the best month (July) reaching 56 (down from 90).

A general abservation emerging from the data is that the $\mathrm{TCl}$ scores in the tropics and subtropics will be severely lowered by climate change, while the zones with good conditions shift towards the poles. Average conditions in the northern parts of Eurasia and North America improve significantly, while those in the northern part of South America, and in central Africa, and Indonesia deteriorate markedly. Experiments with Hatch's climate code yield similar results for the seasonal dynamics in most areas apart from the arctic regions in Eurasia and America. In these zones, which are currently not particularly interesting from a tourism perspective, poor and spring peak regimes are replaced by the summer peak regime, offsetting some of its losses to the bimodal regime in the southern parts of North-America and Eurasia.

More regional specificity was sought for a number of world regions that are of special interest to tourism: the Mediterranean basin. Northern Europe, the United States, Canada, the Caribbean, China, Japan, and Southeast Asia. Other regions for which major changes are expected in the A1F world complemented this set of regions. Figure 6.4 summarises the results.

The northern as well as the southern Mediterranean are characterised by sharp seasonality, but $\mathrm{TCl}$ developments differ significantly between these areas. In the northern Mediterranean, $\mathrm{TCl}$ ratings decrease dramatically in JJA, whereas they increase in the other seasons, particularly in MAM. In the southern Mediterranean, on the other hand, scores increase in D.JF, while they decrease in the other seasons, in particular in JJJA, when the heat becomes unbearable.

Northern Europe and Canada are among the winners with respect to climatic conditions for tourism. In both regions, $\mathrm{TCl}$ performance improves in (almost) every season, in particular in SON; in addition, significant improvements in JJA conditions occur in northern Europe. The expectations for the northern part of the United States are quite similar to those for the northern Mediterranean, with the loss of pleasant conditions in JJA offset by gains in the other seasons. In the southern States, $\mathrm{TCl}$ scores develop rather differently. They deteriorate slightly in MAM and heavily in JJA and SON, but part of this decrease is offset by major improvements in DJF.

Developments in Japan are comparable to those in the northern Mediterranean. JJA conditions deteriorate heavily, while those in SON and DJF, and in

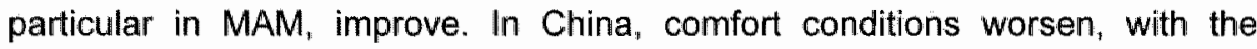
exception of DJF. In this latter season, stable comfort levels in the eastern parts of the country are combined with significant improvements in the south. 


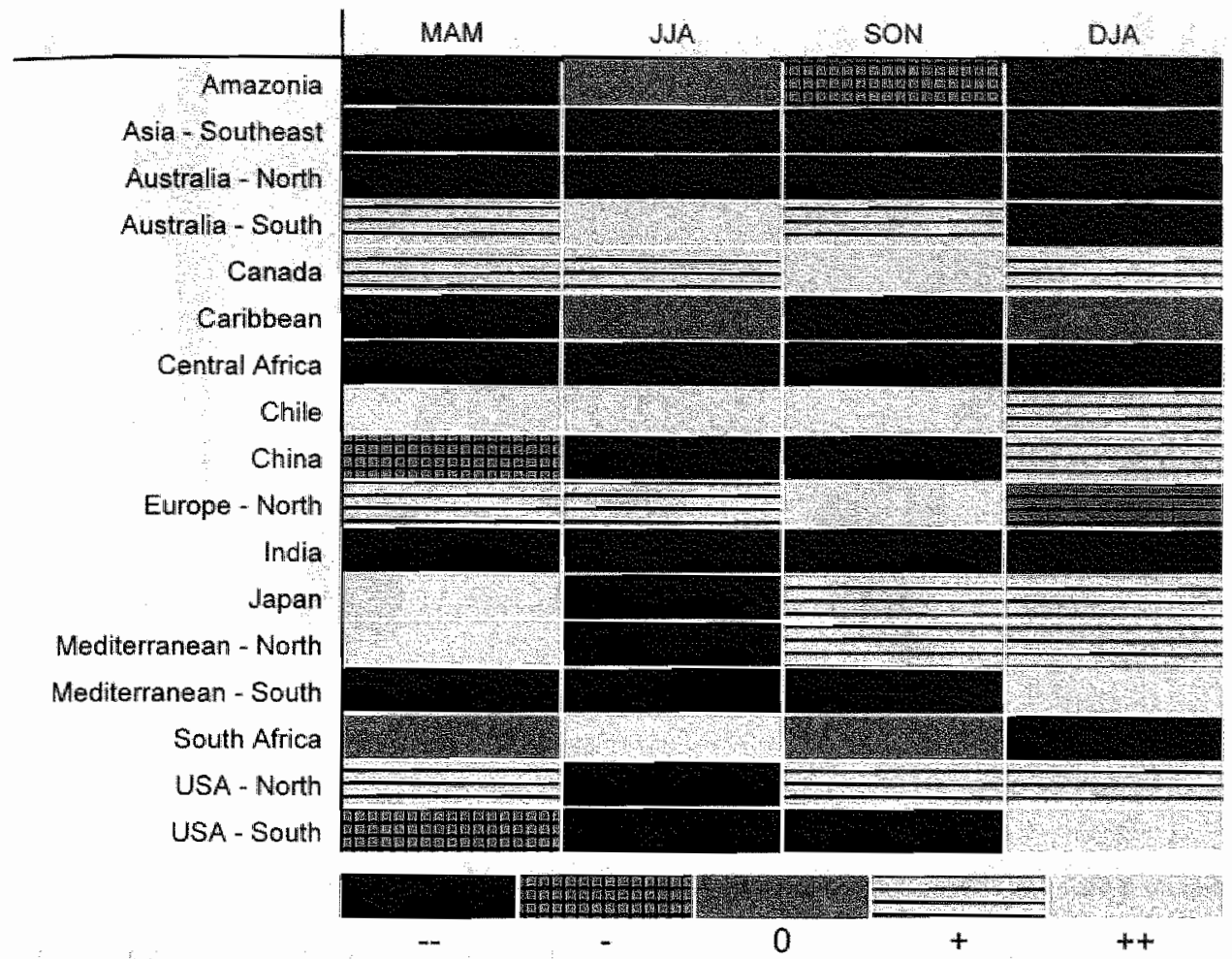

Figure 6.4: Changes in tourist comfort for various tourism regions according to the AfF scenario in the 2080 s compared to the 1970 s.

In the Caribbean, the tropics and northern Australia, $\mathrm{TCl}$ scores deteriorate across the board. This uniformity of (adverse) change is perhaps no surprise given the absence of seasons in the tropics; in any case, the dry season does not appear to be of any relief: In the Southern Hemisphere, there are a few areas for which developments look particularly interesting. Contrary to the overall trend in South America, $\mathrm{TCl}$ scores for Chile improve in all seasons. It is likely that this is a result of the cooling effect of the Andes mountain range, but this hypothesis needs to be investigated further. In South Africa and southern Australia, $\mathrm{TCl}$ ratings remain more or less equal in MAM and JJA. In contrast, conditions improve significantly in $\mathbb{J} J A$, while they deteriorate in DJF.

The above analysis of the shifts in tourism potential that are projected to take place between the 1970 s and the 2080 s might convey the impression that these changes are linear and contain little surprise. This analysis uses comparative statics on only two points in time, however, which does not provide a good sense of the underlying trends and potential discontinuities. By adding a number of intermediate results, some of the downturns of comparative statics can be mitigated. 


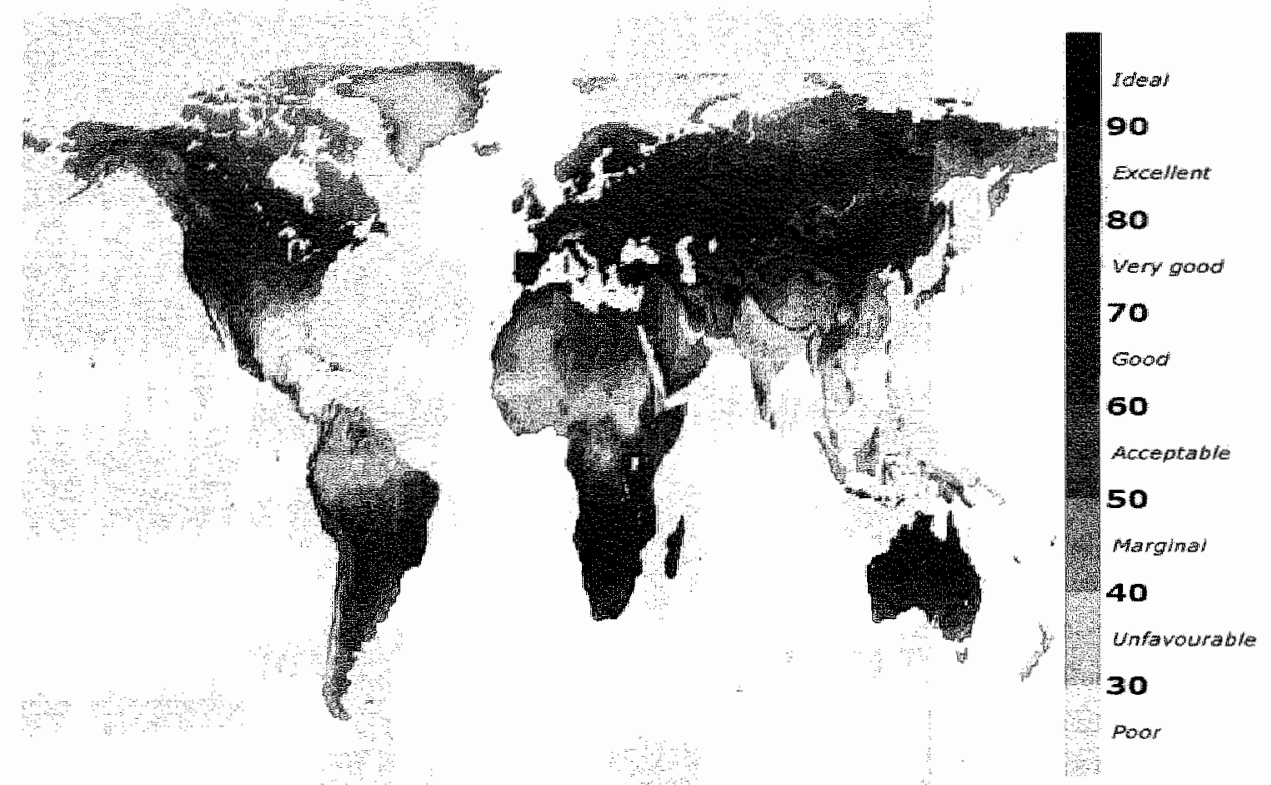

Figure 6.5a:" TCI scores in the June-July-August (JJA) season in the 1970s

Figure 6.5b: TCl scores in the June-Jully-August (JJA) season in the 2020s, according to the integration of the HadCM3 climate model and the SRES A.1F scenario

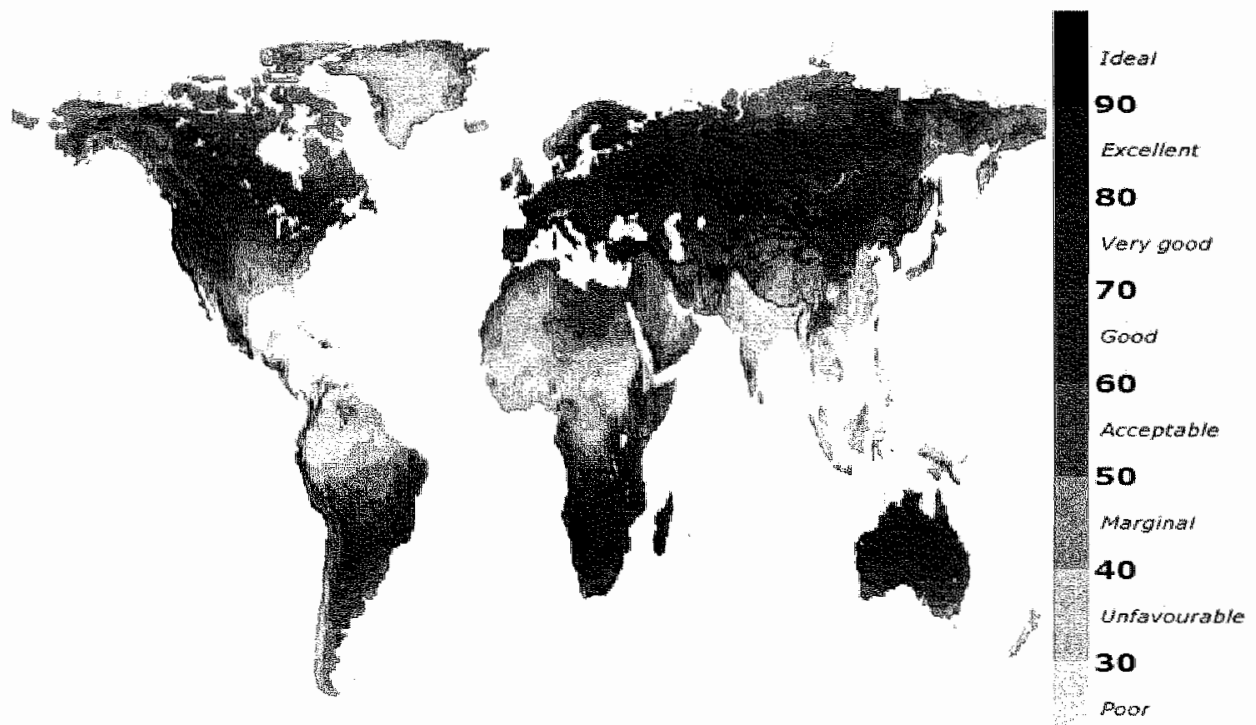




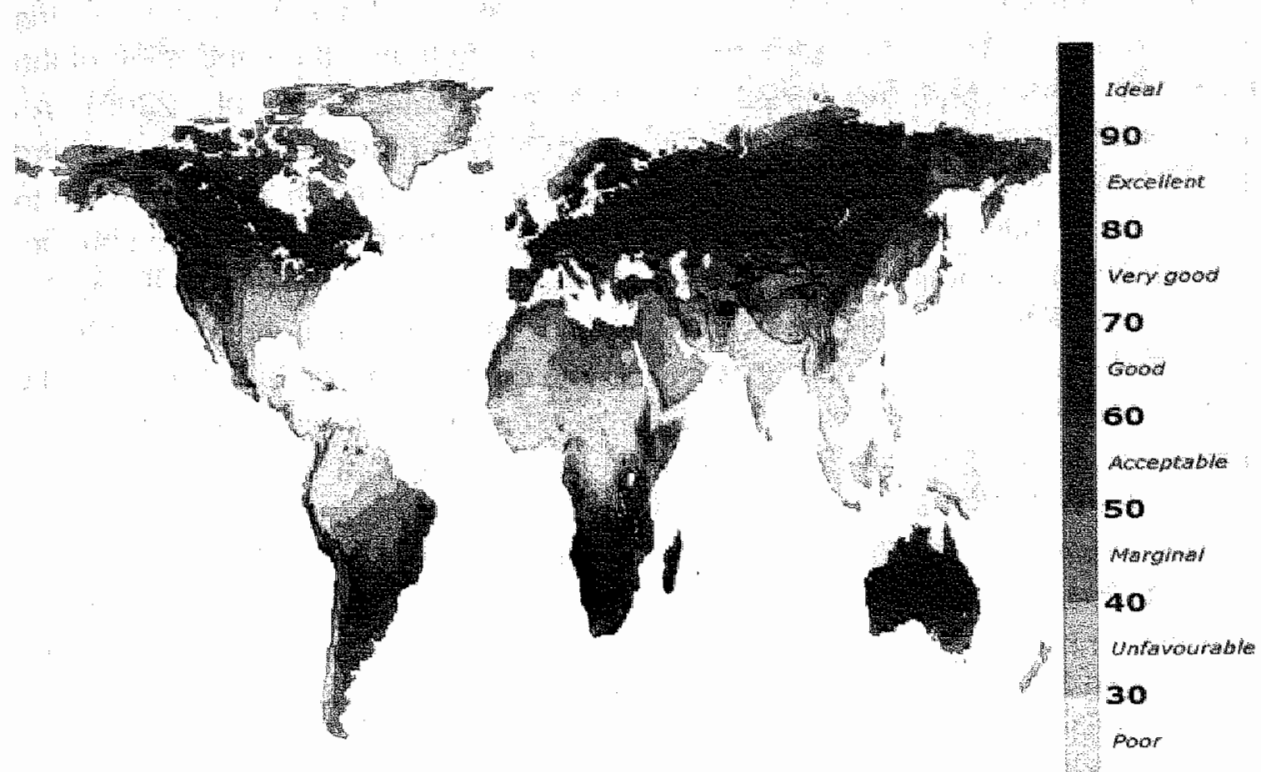

Figure 6.5c: TCl scores in the June-July-August (JJA) season in the 2050s, according to the integration of the HadCM3 climate model and the SRES A1F scenario

Figure 6.5d: TCl scores in the June-July-August (JJA) season in the 2080s, according to the integration of the HadCM 3 climate model and the SRES AUF scenario

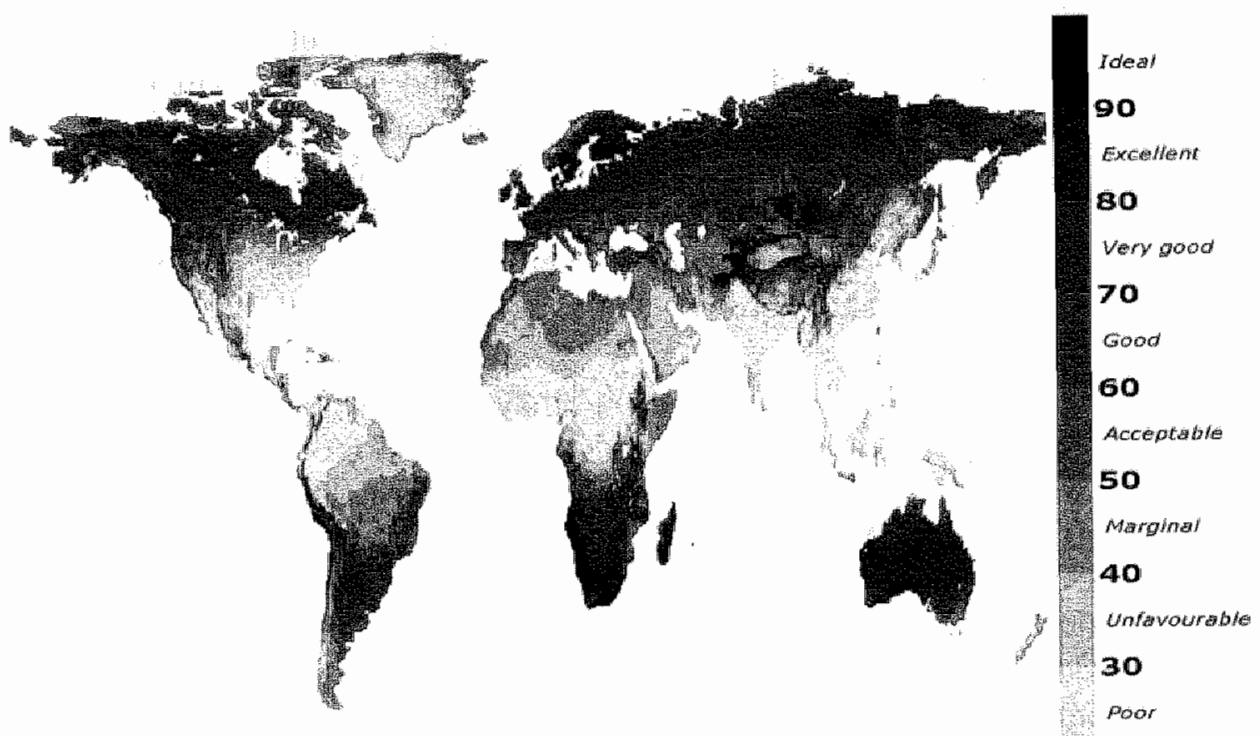


Figure 6.5 presents a succession of TCl worldmaps for the JJA season, relating to the climate states in four periods in time as projected by the integration of the HadCM3 model and the SRES A1F scenario (Amelung et al, 2005). An important finding that emanates from the comparison of these four states is that the TCl improvements in the northern hemisphere's temperate zones turn out to be highly transitional For example, in the AIF scenario of rapid climate change. central France benefits at first, with improved summer conditions in the 2020 , but this benefit gradually turns into a loss as summer conditions start to deteriorate in the 2050 s. More in general, this means that regions that currently feature excellent conditions in a certain season are very likely to experience unequivocal deterioration of their tourism potential in that season, and so do regions towards the equator. Regions that are located polewards from the zone of excellence will experience unequivocal improvement at first. The durability of this improvement, however, depends on the speed and magnitude of climate change. The higher the $\mathrm{CO}_{2}$ concentrations in a new, more or less, stable climate equilibrium, the larger the geographical area that will experience merely temporary improvements as a result of climate change.

For individual destinations, or rather." cells, monthly variations in TCl scores can be calculated, in addition to the mere $\mathrm{TCl}$ distribution category, which is a rather coarse indicator. To illustrate this, results are plotted for four major tourist destinations around the world: Blackpool in the UK "Miami in the United States, Cape Town in South Africa, and Rio de Janeiro in Brazil. Blackpool is illustrative of the changing conditions in the temperate zones in northwestern Europe. Miami is an important destination in the southen United States that has climatic similarities with the Caribbean islands. South Africa was detected as a region with mixed results in terms of $\mathrm{TCl}$ scores and Cape Town is a major tourist destination in this country. Rio de Janeiro is a very well known example of a beach resort in the tropics, which are projected to lose climatic attractiveness in the years to come. A special section is dedicated to the Balearics. On these islands, many climate-related problems converge, such as temperature change, sea level rise and water shortages.

In Blackpool the TCl distribution remains firmly 'summer peak'. However, the mean TCl rating will improve considerably (see Figure 6.6a). In JJA, climatic conditions will change from fair to very good or even excellent. Blackpool is an example of the significant improvements in TCl scores in northern Europe. Climate change fortifies the winter peak distribution that currently characterises Miami and the rest of Florida (see Figure 6.6b). Conditions in DJF improve even further, while those in JJA continue deteriorating. In combination with the DJF improvement relative to the northern states in the country, these developments are expected to further strengthen Miami's and Florida's position as a prime destination for US residents to pass the winter season. 


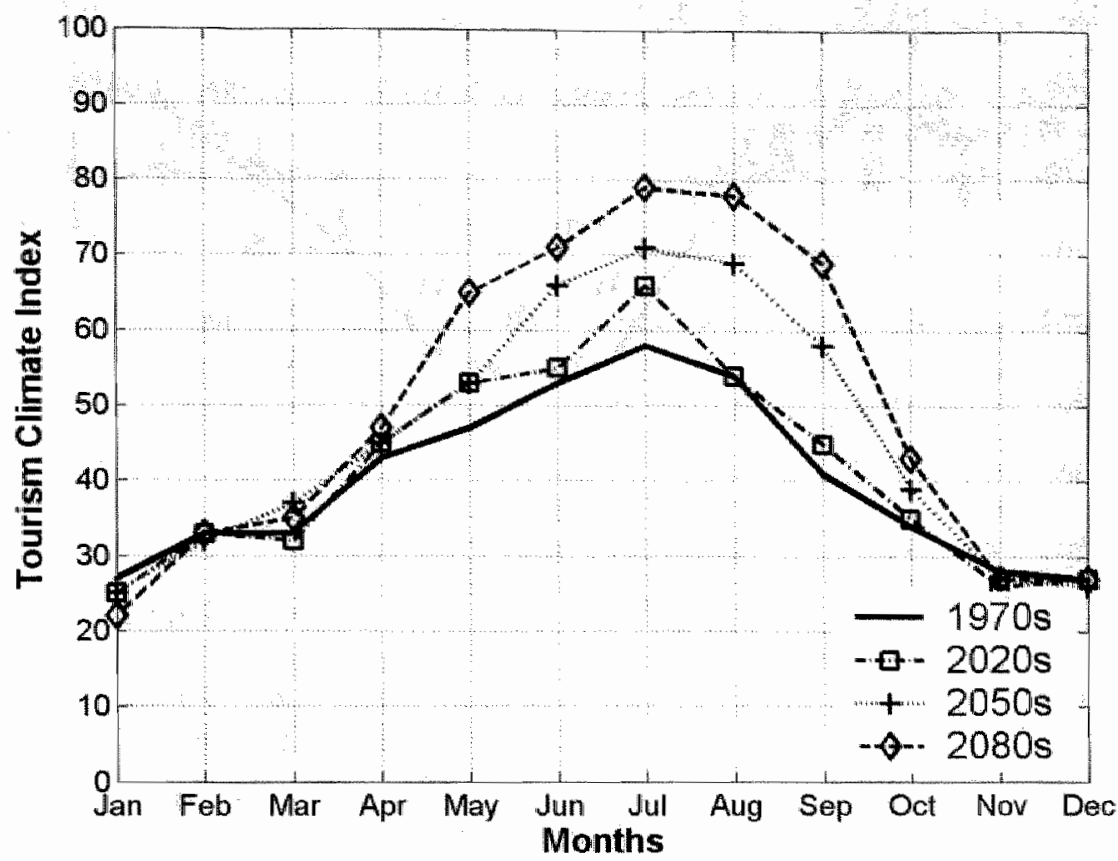

Figure 6.6: TCl distribution in the 1970s (baseline) and the 2020s, 2050s, and 2080s (A1F scenario) for Blackpooll, UK (top, a) and Miami, USA (bottom, b)

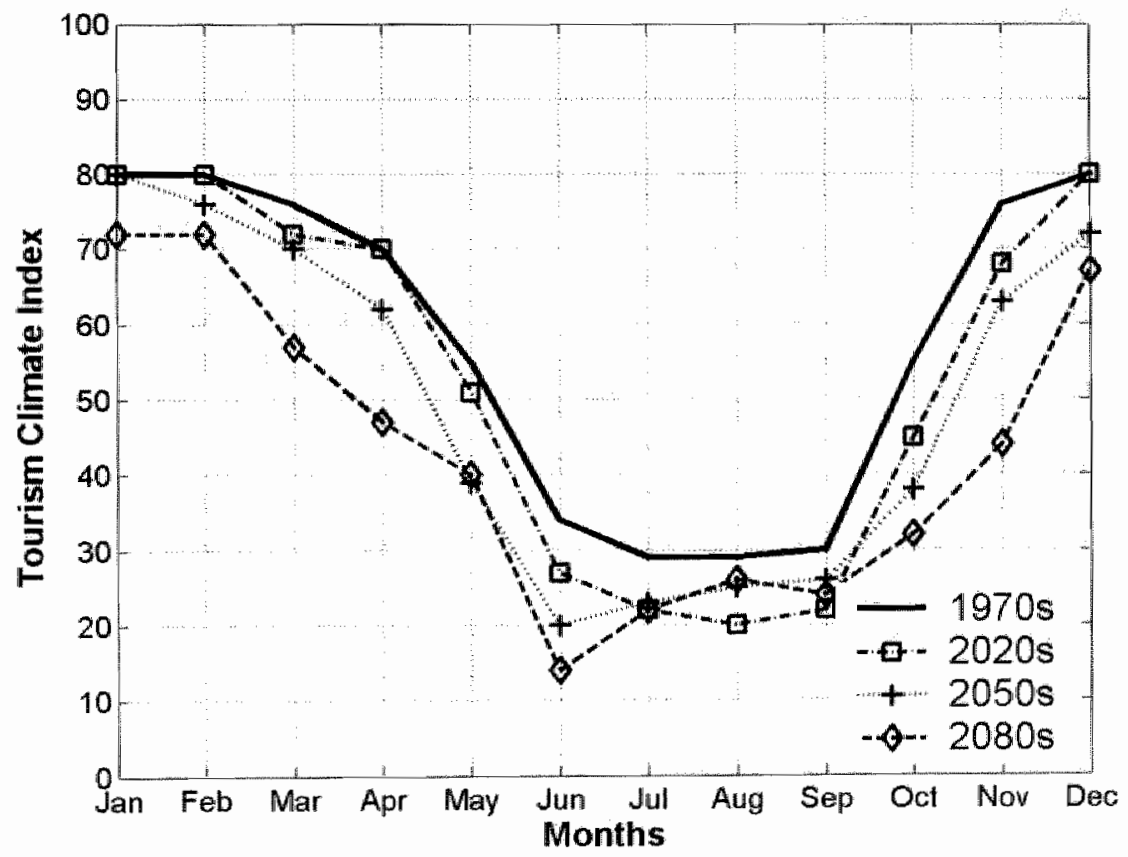




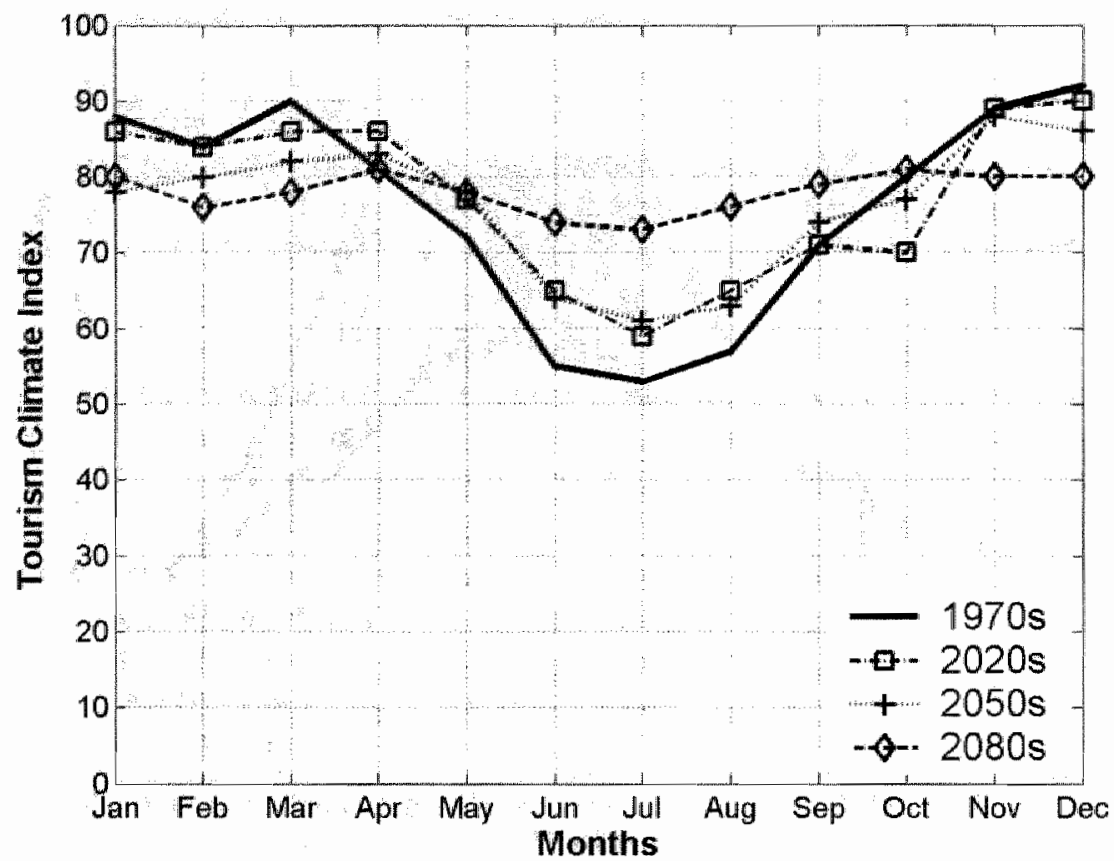

Figure 6.6: TCl distribution in the 1970s (baseline) and the 2020s, 2050s, and 2080s (A.1F scenario) for Cape Town, South Africa (top, c) and Rio de Janeiro, Brazil (bottom, d)

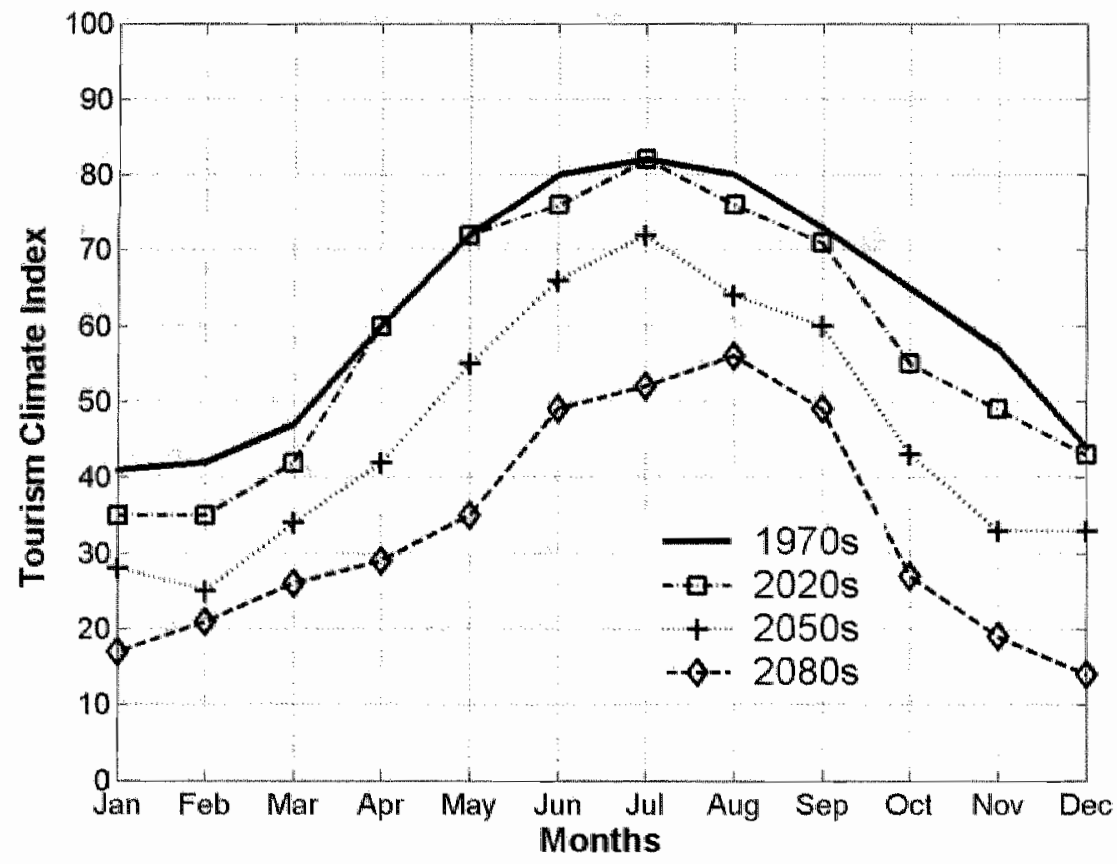


The South African coast is projected to be among the few regions in Africa that are not projected to face large losses of $\mathrm{TCl}$ scores throughout the year (see Figure 6.6c). Although conditions deteriorate in D.JF (the South African summer), $\mathrm{TCl}$ scores are stable or moving up in the other seasons. The Cape Town climate is predicted to become less clearly summer peak and to move towards a bimodal or even a winter peak distribution.

The climatic attractiveness of the Amazonian parts of South America deteriorates in large parts of the year. This is no different for the famous beach resort of Rio de Janeiro (see Figure 6:6d). The decrease in $\mathrm{TCl}$ levels will be spread more or less equally across the entire year, so that the resort will remain winter peak. It is the almost exact opposite of Blackpool, a resort characterised by a summer peak distribution, for which increases are predicted throughout the year.

\subsection{Balearics case study}

In 2002, some 47.4 million nights were spent in hotels in the Balearic Islands; another 11.6 million nights were spent in tourist apartments (INE, 2004). The number of nights spent in other types of accommodation was insignificant. In total some 59 million nights were spent in 2002. Of these, over 6 million can be attributed to domestic tourists, but foreign tourists make up the lion's share, with close to 53 million nights spent. The British (42\%) and Germans (37\%) combined account for almost $80 \%$ of these. Foreign tourist demand in the Balearics features a high level of seasonality. While from November to April the Balearic Islands account for less than $20 \%$ of total foreign tourist demand in Spain, this percentage rises to over $40 \%$ in the summer months of June, July and August (see Figure 6.7). Domestic demand is distributed more evenly.

Aguilo et al. (2005) report on the motives for visiting the Balearics that tourists mentioned over the period 1993-2000. The climate is ranked highest $(76.2 \%)$, followed by the beaches $(51.2 \%)$, and price $(36.4 \%)$. The authors assert that empirical data support neither the claims of structural weaknesses of sun and sand mass tourism (Knowles and Curtis, 1999) nor the reduced importance of a destination's climate or beaches (Weiermair, 2001). In spite of all the attention for new trends, $86 \%$ of all high-season tourists in the year 2000 visited the Balearic Islands on a package holiday, which is still the most common form of travel for Europeans (Aguiló et al. 2005).

The dominance of climate and beaches over potential other factors in terms of attracting tourists makes the Balearics a prime region for testing and applying the $\mathrm{TCl}$. Figure 6.8 links monthly visitation levels to monthly $\mathrm{TCl}$ scores. It 
depicts the number of tourist nights spent in the Balearic Islands by foreign tourists in the years 1999 to 2003 as bars. The line in the figure represents the mean $\mathrm{TCl}$ scores for the Balearics, based on the 1961-1990 dataset compiled by the Climatic Research Unit (New et al., 1999). The figure is not meant to link weather conditions in specific years to visitation levels in those same years; rather, its function is to illustrate the link between average climatic conditions and 'normal' visitation levels.

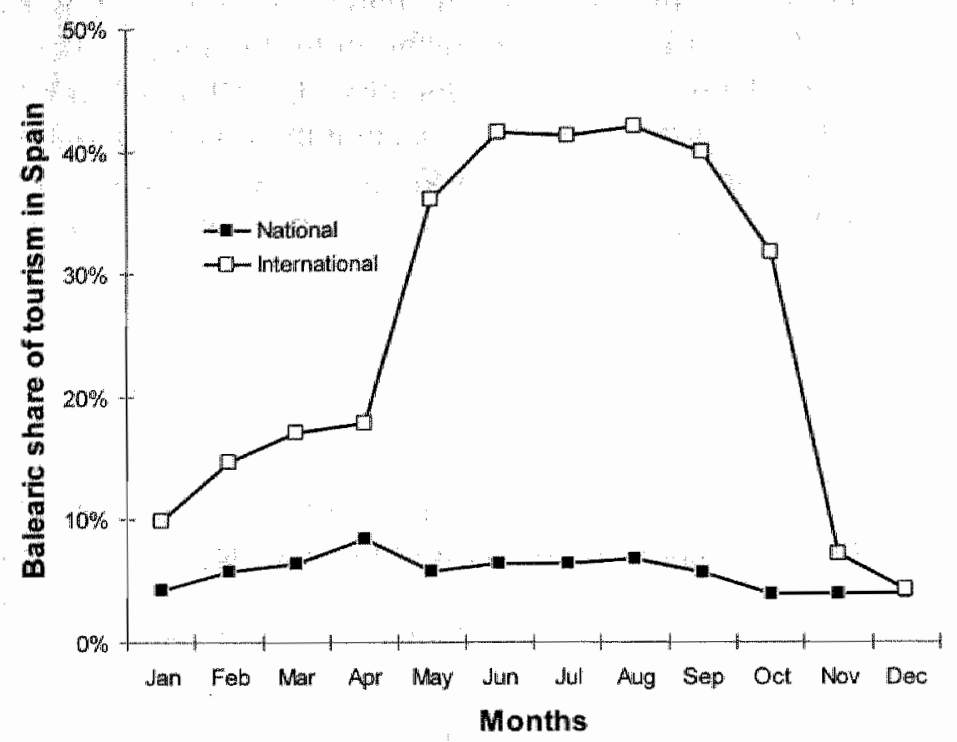

Figure 6.7: Percentage of total tourists nights in Spain spent in the Balearics in 2002 Source: INE (2004)

Mieczkowski (1985) suggested to use a classification of TCl scores in which scores over 70 represented 'very good' climatic conditions, levels of over 80 corresponded with 'excellent' conditions, and scores of 90 or more were considered 'ideal'. The validity of this classification is tested here. Figure 8 suggests that there is a strong relationship between $\mathrm{TCl}$ scores and visitation levels. More than $88 \%$ of the annual nights spent by foreign tourists correspond to the six months with $\mathrm{TCl}$ scores exceeding 70 or even 75 , i.e. May to October. Outside of these six months, both $\mathrm{TCl}$ scores and visitation levels are sharply lower.

In order to illustrate the potential effects of climate change, $\mathrm{TCl}$ values have been calculated for the Balearics for a number of future time slices: 2010-2039 (the '2020s'), 2040-2069 (the '2050s'), and 2070-2099 (the '2080s') and for a number of emissions scenarios. Figure 6.9 plots the future $\mathrm{TCl}$ scores for the A1F scenario. In order to facilitate easy interpretation, the monthly averages for foreign visitation over the period 1999-2003 have been added to the plot. 


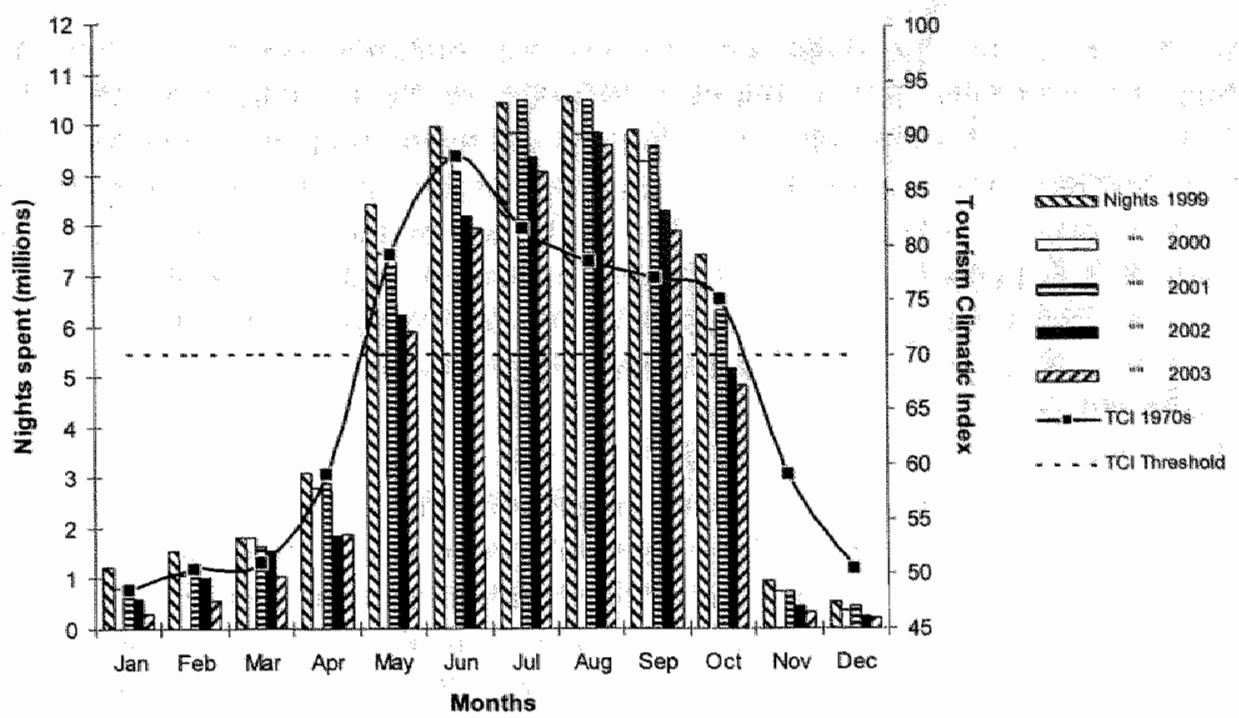

Figure 6.8: Tourist nights spent in the Balearics by foreigners in relation to scores the Tourism Climatic Index

Source: $\quad$ Based on INE (2004)

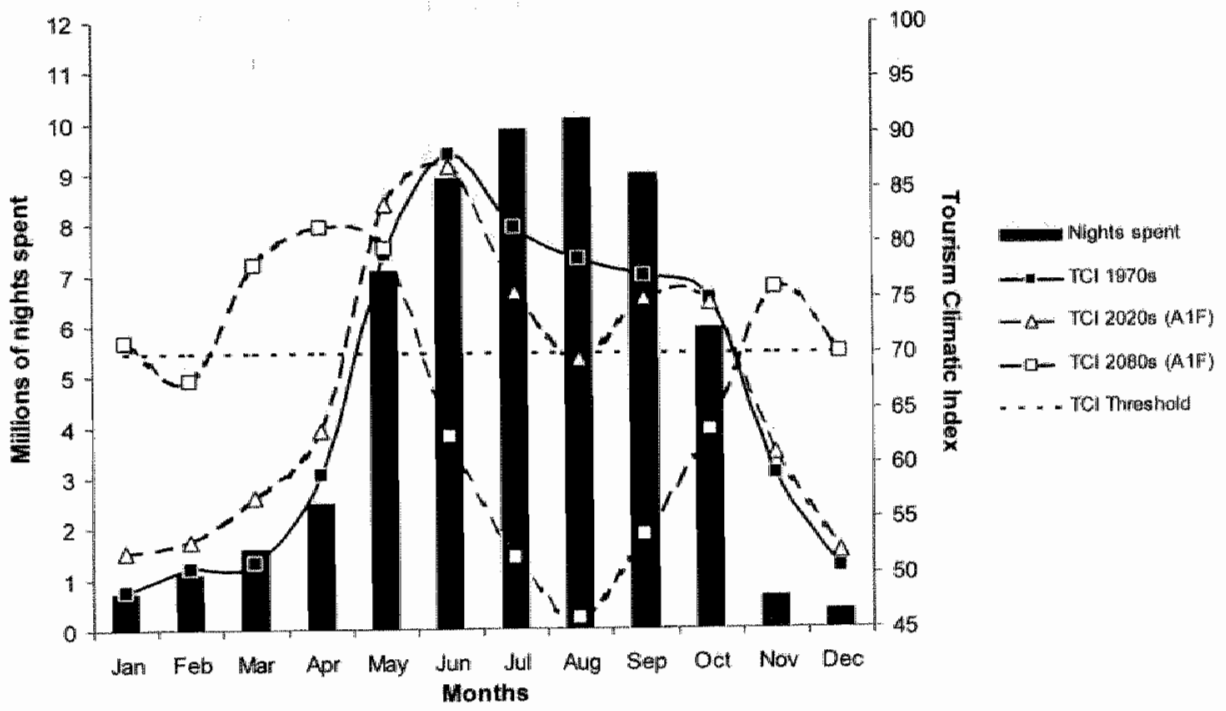

Figure 6.9: Exploration off future TCl scores in the Balearics

Source: Based on INE (2004) 
Up to the 2020s, the projected changes are relatively modest. In July and August in particular, $\mathrm{TCl}$ scores decrease significantly, but they stay above the threshold of 70 . By the 2080 s the situation will have changed completely. The four months that are currently the most popular ones (June, July, August and September), rating highest on the $\mathrm{TCl}$ scale, will by then be characterized by the lowest TCl scores. Of the current six high-season months only May attains a score of more than 70 . Spring conditions in the 2080s, on the other hand, will be very good or excellent, displaying a sharp contrast with the current 'acceptable' classification.

Provided that climatic conditions will remain important push and pull factors for tourism in the future, these preliminary results point to important implications for tourism in the Balearics. The remarkable seasonal concentration of today, with $88 \%$ of all nights spent in the six months from May to October, will likely change. Not only do $\mathrm{TCl}$ scores in all but one of these months drop below the 70-threshold in the Balearics; in the source countries the opposite will happen. In the summers of the 2080s, potential tourists in the UK and Germany will be able to find much better climatic conditions in their own country (e.g. Blackpool, see Figure 6) than in the Mediterranean region.

Simultaneously, climate change seems to offer possibilities for expansion in early spring (March and April), in particular in the domestic market. Only $7 \%$ of nights spent by foreign tourists in 2002 were associated with these two months, compared to $36 \%$ in July and August. For the Spanish tourists, these percentages were $20 \%$ and $31 \%$ respectively. Higher revenues in spring may offset part of the economic losses that are caused by the deteriorating climate. Given the rigidity of the institutions that favour summer as the main tourism season, however, this compensation will likely be partial at best. Given the fact that in the Balearics, tourism accounts for over $60 \%$ of GDP (Batle, 2000), the impacts may be substantial.

Employment patterns closely follow tourist demand, with hotels employing almost 41000 people in August and 5000 in December of 2002, and the tourist apartment industry employing 9000 in August and almost none in December (INE, 2004). In August, the accommodation sector alone accounts for almost $14 \%$ of employment in the Balearics; almost $75 \%$ of the active population is employed in the service sector, a large share of which is tourism related. The need to accommodate seasonal employment in the tourist industry places great demands on the economic and social structures of the Balearics. The employees that the tourist industry needs in summer are partly absorbed by the islands' other industries in winter, and partly 'imported' from other Spanish regions or abroad. Between 1960 and 2001, the resident population of the 
Balearics rose from some 360 thousand to over 700 thousand. which is a clear indication of the demographic response to the tourist boom (Essex et al., 2004). Given the scale of these seasonal migration patterns, social consequences may be large. Drastic changes in the situation, such as those painted by the Alf scenario, will undoubtedly change the social dynamics on the Balearics.

The availability of drinking water and sewage systems has been a problem in the Balearics for a long time (Aguilo et al., 2005). The annual influx of tourists increases the demand for water well beyond the normal requirements of the resident population and the capabilities of local water sources (Essex et al., 2004). Moreover, tourists typically use relatively more water than local inhabitants (Holden, 2000); the amount of water that is used to irrigate Majorca's golf courses would be enough to supply the populations of Calvia and Palma with drinking water (Essex et al., 2004). Water demand for tourism and irrigation is highest in the main holiday season, which coincides with the driest weather. In contrast, virtually all precipitation on the largest island of Majorca occurs in the autumn and winter months, with the wettest months typically being October to December (Kent et al., 2002). The rising demand for water has been met by increased extractions of ground water. Around Palma, the water table has fallen by about 100 metres between 1973 and 1994 (Wheeler, 1995). Large water shortages are forecast for the future (Palmer and Riera, 2003), and climate change is expected to exacerbate the situation by reducing precipitation even further (Essex et al., 2004; Kent et al., 2002). Perhaps the expected reduction in tourist visitation levels in summer can bring some relief.

The Mediterranean basin is considered a "hyper-hot' candidate for conservation support in light of their exceptional totals of endemic plants (Myers et al., 2000). Furthermore, the Mediterranean Sea is rich in marine biodiversity, and a healthy marine ecosystem is appreciated for bathing, tourism or simply aesthetic enjoyment (Bianchi and Morri, 2000). The Mediterranean biome is expected to experience a relatively large change of diversity as a result of climate change (Chapin III et al., 2000). The impact of tourism on biodiversity is difficult to assess, but given tourism's significant claims on the key conditions for biodiversity (i.e. land and water resources) in the Balearics, it can be safely assumed to be substantial. If the shift in tourist demand from summer to spring materialised, this would greatly reduce pressure on biodiversity in summer, but increase pressure in spring, the mating season for many species.

The results of the qualitative assessment of the implications that climate change may have for sustainable tourist development are summarised in Table 6.3. The results are split up into the four seasons of the year, acknowledging the great differences in outcome between the seasons. 


\begin{tabular}{lccccc}
\hline & Spring & Summer & Autumn & Winter & Net effect \\
\hline Revenues & ++ & - & - & ++ & - \\
Occupancy & ++ & - & 0 & ++ & + \\
Employment & ++ & - & - & ++ & - \\
Migration & + & - & - & 0 & - \\
Water use & ++ & - & - & ++ & - \\
Impact on Biodiversity & +++ & - & - & + & - \\
\hline
\end{tabular}

Table 6.3: Qualitative assessment of the impact of climate change (A1F scenario) on sustainable tourism development in the Balearics in the 21 st Century

\subsection{DISCUSSION}

Calculations with climatic indices for tourism, such as Mieczkowski's TCI or Hatch's climate code seem to yield realistic results, matching common perceptions of the seasonal attractiveness of major tourist destinations. These indices reproduce, for example, the favourable conditions and the popularity of the Mediterranean and Californian summer (JJA) and the Florida and Caribbean winter (DJF). They also reproduce the poorer conditions in large parts of the tropics, due to extreme heat and high levels of relative humidity.

Experiments with the indices also confirm that in the vast majority of regions, climatic attractiveness varies between the seasons. Regions with scores that are consistently high ('optimal') or low ("poor") are relatively scarce. The summer peak distribution is dominant in the moderate zones in the northern hemisphere, i.e. in a large part of North America and almost all of Eurasia. Due to the much smaller amounts of land in the moderate zones in the southern hemisphere, the summer peak regime is much less prominent over there. The tropics and subtropics are dominated by the winter peak regime, punctuated by some patches of poor conditions around the equator. In the northern as well as in the southern hemisphere, the bimodal regime separates the summer and winter peak regimes. Isolated areas with spring and autumn peak distributions can be found on the edges of the bimodal zones, but they are not clustered into larger areas and they are numerically of little importance.

Validation of climatic indices for tourism is of major importance. After all, the indices pretend to be predictors for the segment of tourist demand that is climate-sensitive. So far, validation has been performed for a limited number of individual destinations. These results are encouraging, but more statistical analyses testing the explanatory power of index scores would be very welcome. Improvements are needed on the conceptual side as well. Data availability has 
been improved significantly, which makes the development of new and better indices feasible.

In this chapter, the sensitivity of outcomes for different weighting factors and variables was tested. Firstly, results obtained with Mieczkowski's TCl were compared with results obtained with Hatch's climate code. Differences were largest in the moderate climatic zones of northern Europe and North America, with the scores on the climate code consistently lower for these areas, particularly in summer. The greater weight of precipitation in the climate code appears to be the key factor in explaining these differences. Secondly, two alternative implementations of thermal comfort in the $\mathrm{TCl}$ were used to test sensitivity. Both implementations yielded similar results, with the exception of the tropics and the subtropics. In these areas, calculations based on the effective temperature concept originally used by Mieczkowski yielded consistently higher scores than those based on Steadman's apparent temperature concept.

Climate change is surrounded by many uncertainties; not just in the climate system, but also, and probably more importantly, in the societal response. The results presented in this chapter are therefore no predictions; rather, they are explorations of possible implications. Scenarios, such as those developed by the IPCC, are commonly used for this type of explorations. Applied to the climatic attractiveness of destinations for tourism, these scenarios were shown to yield very different results, in particular in terms of rates of change. The direction of change, however, was consistent across all scenarios considered.

The most widely used General Circulation Model (HadCM3) produced the climate projections used in this chapter. Nevertheless, in future sensitivity analyses, multiple GCMs should be included to cover a wider range of possible assumptions about climatic and societal responses.

The impact of climate change on tourist comfort is potentially very large. In some extreme cases, the annual mean score changes by as much as 25 points, in both directions. Moreover, the whole pattern of seasonal regimes changes dramatically. The bimodal regime, with scores in the MAM and SON seasons higher than in DJF and JJA, advances into southern Europe and large parts of North America. At the same time, the regime of poor conditions expands significantly around the equator.

Comfort conditions in Canada and northern Europe seem to benefit most from climate change, particularly in summer, while comfort in the traditional destinations around the Mediterranean Sea deteriorates in JJAA, and improves in MAM. The results for Europe confirm those of Rotmans et al. (1994), who also 
found a significant deterioration of summer conditions around the Mediterranean, and an improvement of summer conditions in Western Europe and along the Baltic coasts. The results presented here for North America are also comparable with those of Scott and McBoyle (2001), and Scott et al. (2004).

Within Europe, such changes may have massive consequences. Particularly in the summer (JJA), tourist patterns will change, as conditions in the traditional source markets improve while those in the traditional destinations deteriorate. Large financial fluxes associated with north-south tourist flows within Europe may decrease significantly or cease completely. However, this adverse summer (JJA) Irend may be partly or completely offset by increasing revenues in the shoulder seasons, in particular the MAM season. Several current trends would be favourable to such a development. For example, ageing and increasing individual choice in the allocation of time point in the direction of greater flexibility in the timing of holidays. Such connections are as yet unexplored, but merit future attention.

Another issue worth attention is the impact on tourism in less developed countries. Currently, possibilities are being explored and developed to alleviate poverty by means of tourism developments (WTO, 2002). In many of the less developed countries, these ambitions could be hampered by the adverse impacts of climate change on tourist comfort. The analyses in this chapter suggest a very large deterioration in large parts of Africa, Central and South America, and Indonesia. This is a reason for concern and further study.

The significance of climate change in the broader picture of influences on tourist development is a further direction for additional study. Tourist developments are shaped by an amalgam of factors, including political stability, economic growth, technological advances, and demography. In the day-to-day practice of the tourist industry, climate factors are overwhelmed by all kinds of other influences that require immediate action, such as SARS, fads and fashion, and terrorism. Climatic effects on tourist comfort will perhaps not be so evident, but the compound effect of years of creeping change can have quite dramatic results, which are irreversible in a human lifetime.

In this chapter, the focus has been on monthly and annual means of climatic variables. Perhaps even more important than means are extreme events, such as heat waves, torrential storms, and gales. As the frequency of these extreme events is expected to increase due to climate change, their effects may provide the first signs that climate change is having an effect on comfort. 


\section{Acknowledgements}

This chapter resulted from the author's visit to the Climatic Research Unit (University of East Anglia), 3 to 26 August 2003. The HadCM3 data have been supplied by the Climate Impacts LINK Project (DEFRA Contract EPG 1/1/154) on behalf of the Hadley Centre and U.K. Meteorological Office.

\section{References}

Agnew, M. D. and Viner, D. (2001). "Potential impacts of Climate Change on International Tourism." International Journal of Tourism and Hospitality Research, 3(1): 37-60.

Aguili, E., Alegre, J. and Sard, M. (2005). "The Persistence of the Sun and Sand Tourism Model." Tourism Management, 26(2): 219-231.

Amelung, B. Nicholls, S. and Viner, D. (2005). "Implications of Climate Change for Tourism: A Global Analysis." Poster presented at the 2005 conference of the Travell and Tourism Research Association (TTRA), 12-15 June 2005, New Orleans.

Amelung, B. and Viner, D. (in press). "Mediterranean Tourism: Exploring the Future with the Tourism Climatic Index." Journal of Sustainable Tourism.

Batte, J. (2000). "Rethinking Tourism in the Balearic Islands." Annals of Tourism Research, 27(2): 524-526.

Bianchi, C. N. and Morri, C. (2000). "Marine Biodiversity of the Mediterranean Sea: Situation, Problems and Prospects for Future Research." Marine Pollution Bulletin, 40(5): 367-376.

Chapin II. F. S., Zavaleta, E. S., Eviner, V. T., Naylor, R. L., Vitousek, P. M., Reynolds, H. L., Hooper, D. U., Lavorel, S., Salal, O. E., Hobbie, S. E., Mack, M. C. and Diaz, S. (2000). "Consequences of Changing Biodiversity." Nature, 405: 234-242.

Elsasser, H. and Bürki, R. (2002). "Climate Change as a Threat to Tourism in the Alps." Climate Research, 20(3): 253-257.

Elsasser, H. and Messerli, P. (2001). "The Vulnerability of the Snow Industry in the Swiss Alps." Journal of Mountain Research and Davelopment, 21(4): 335-339.

Essex, S., Kent, M. and Newnham, R. (2004). "Tourism Development in Mallorca: Is Water Supply a Constraint?" Journal of Sustainable Tourism, 12(1):4-28.

Hamilton, J. M. (2003). "Climate and the Destination Choice of German Tourists." Working Paper FNU-15 (revised), Research Unit Sustainability and Global Change, Centre for Marine and Climate Research, University of Hamburg: Hamburg.

Hamilton, J. M. Maddison, D. and Tol, R. S. J. (2005). "Climate Change and International Tourism: A Simulation Study." Global Enwironmental Change, 15(3): 253-266.

Harrison, S. J., Winterbottom, S. J. and Sheppard, C. (1999). "The Potential Effects on Climate Change on the Scottish Tourist Industry." Tourism Management, 20(2): 203-211.

Hatch; D. (1984). "Weather around the World: Standardized Climatic Data for 500 Places, Tabulated, Ranked and Mapped." Arnsterdam.

Hatch, D. (1988). "The Distribution of World Climate Conditions." Journal of Meteorology, 13(133s): 344-349.

Holden, A. (2000). Environment and Tourism, Routledge: London, UK. 
Hullme, M. Jenkins, G. J, Lu, X., Tumpenry, \&.R. Mitchell, T. D, Jones, R. G., Lowe, M. Murphy, J. M. Hassell, D. Boorman, P., McDonald, R. and Hill, S. (2002). "Climate Change Scenarios for the United Kingdom: The Ukcip02 Scientific Report." Tyndall Centre for Climate Change Research, School of Environmental Sciences, University of East Anglia: Norwich, UK.

INE (2004). "Encuesta De Ocupacion Hotelera 2003," Spanish Statistical Institute (INE).

IPCC (2001). Climate Change 2001: Synthesis Report Cambridge University Press: Cambridge. United Kingdom; and New York, NY, USA.

Johns, T. C., Gregory, J.M., Ingram W. J., Johnson, C. E., Jones, A., Lowe, J. A., Mitchell, J. F. B., Roberts, D. L., Sexton, D. M. H. Stevenson, D. S. Tett, S. F. B. and Woodage, M. J. (2003). "Anthropogenic Climate Change for 1860 to 2100 Simulated with the Hadcm3 Model under Updated Emissions Scenarios." Climate Dynamics(Online First, 18 Feb 2003 (DO) 10.1007/s00382-002-0296-y)).

Kent, M., Newnham, R. and Essex, S. (2002), "Tourism and Sustainable Water Supply in Mallorca: A Geographical Analysis." Applied Geography, 22(4): 351-374.

Knowles, T. and Curtis, S. (1999). "The Market Viability of European Mass Tourist Destinations: A Post-Stagnation Life-Cycle Analysis." International Journal of Tourism Research, 1(2): 87-96.

Lise, W. and Tol R. S. J. (2002). "Impact of Climate on Tourist Demand." Climatic Change, 55(4): $429-449$.

Maddison, D. (2001). "In Search of Warmer Climates? The Impact of Climate Change on Flows of British Tourists. " Climatic Change, 49(1/2): 193-208.

Mather, S., Viner, D. and Todd, G. (2005). "Climate and Policy Changes: Their Implications for International Tourism Flows." in: Hall, M. and Higham, J. (eds.) Tourism, Recreation and Climate Change, Channel View Publications: Clevedon, UK, 63 85 .

Matzarakis, A. (2001a). "Assessing Climate for Tourism Purposes: Existing Methods and Tools for the Thermal Complex." First International Workshop on Climate, Tourism and Recreation. Halkidiki, Greece.

Matzarakis, A. (2001b). "Climate and Bioclimate Information for Tourism in Greece." First International Workshop on Climate, Tourism and Recreation "Halkidiki "Greece.

Meteorological Service of Canada (2003). "Wind Chill Science and Equations." Meteorological Service of Canada.

Mieczkowski, Z. (1985). "The Tourism Climatic Index: A Method of Evaluating World Climates for Tourism." The Canadian Geographer, 29(3): 220-233.

Monteith, J. L. (1965). "Evaporation and the Environment." The State and Movement of Water in Living Organisms. Proceedings of Th 19th Symposium, Cambridge University Press: London.

Myers, N., Mittermaler, R. A., Mittermeier, C. G., Da Fonseca, G. A. B. and Kent, J. (2000). "Blodiversity Hotspots for Conservation Priorities." Nature, 403(24): 853-858.

New, M. Hulme, M. and Jones, P. (1999). "Representing Twentieth Century Space-Time Climate Variability. Part 1: Development of a 1961-90 Mean Monthly Terrestrial Climatalogy." Journal of Climate, 12(3): 829-856.

Palmer, T. and Riera, A. (2003). "Tourism and Environmental Taxes. With Special Reference to the "Balearic Ecotax"." Tourism Management, 24(6): 665-674.

Perry, A. H. (2000a). "Impacts of Climate Change on Tourism in the Mediterranean: Adaptive Responses." 35.2000 , Fondazione Eni Enrico Mattei

Perry. A. H. (2000b). "Tourism and Recreation." in: Parry, M. L. (ed.) Assessment of Potential Effects and Adaptations for Climate Change in Europe: The Europe Acacia Project, Jackson Environment Institute, University of East Anglia: Norwich, UK.

Perry. A. H. (2001). "More Heat and Drought-- Can Mediterranean Tourism Survive and Prosper?" First International Workshop on Climate, Tourism and Recreation, Halkidiki, Greece. 
Rotmans, J. Hulme, M. and Downing, T.E. (1994). "Climate Change Implications for Europe." Global Environmental Change, 4(2); $97-124$.

Scott, D. and McBoyle, G. (2001). "Using a Modified Tourism Climate Index" to Examine the Implications of Climate Change for Climate as a Natural Resource for Tourism." First International Workshop on Climate, Tourism and Recreation, Halkidiki, Greece.

Scott, D., McBoyle, G., Mills, B. and Wall, G. (2001). "Assessing the Sensitivity of the Alpine Sking Industry in Ontario, Canada to Climate Variability and Change." First International Workshop on Climate, Tourism and Recreation, Halkidiki, Greece.

Scott, D., McBoyle, G. and Schwartzentruber, M. (2004). "Climate Change and the Distribution of Climatic Resources for Tourism in North America." Climate Research, 27(2): 105-117.

Siple, P. A. and Passel, C. F. (1945). "Measurements of Dry Atmospheric Cooling in Subfreezing Temperatures." Proceedings of the American Philosophical Society, 89(1): 177-199.

Skinner, C. J. and De Dear, R. J. (2001). "Climate and Tourism - an Australian Perspective. "First international Workshop on Climate, Tourism and Recreation, Halkidiki, Greece.

Steadman, R. G. (1984). "A Universal Scale of Apparent Temperature." Journal of Climate and Applied Meteorology, 23: 1674-87.

Viner, D. and Amelung, B. (2003). "Climate Change, the Environment and Tourism: The Interactions. Proceedings of the Esf-Lesc Workshop." Climate change, the Environment and Tourism: The Interactions, Milan 4-6th June.

Weiermair, K. (2001). "Improvements in Competitiveness for Tourism Enterprises through Now Forms and Regimes of Governance." Seminar on Tourism Policy and Economic Growth, Berlin.

Wheeler, D. (1995). "Majorca's Water Shortages Arouse Spanish Passions." Geography, 80(3): 283-286.

WTO (2002). "Tourism and Poverty Alleviation." World Tourism Organization: Madrid, Spain. 


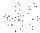




\section{Chapter 7}

The consequences of climate change for tourism and recreation in a Dutch context 


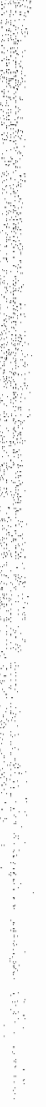
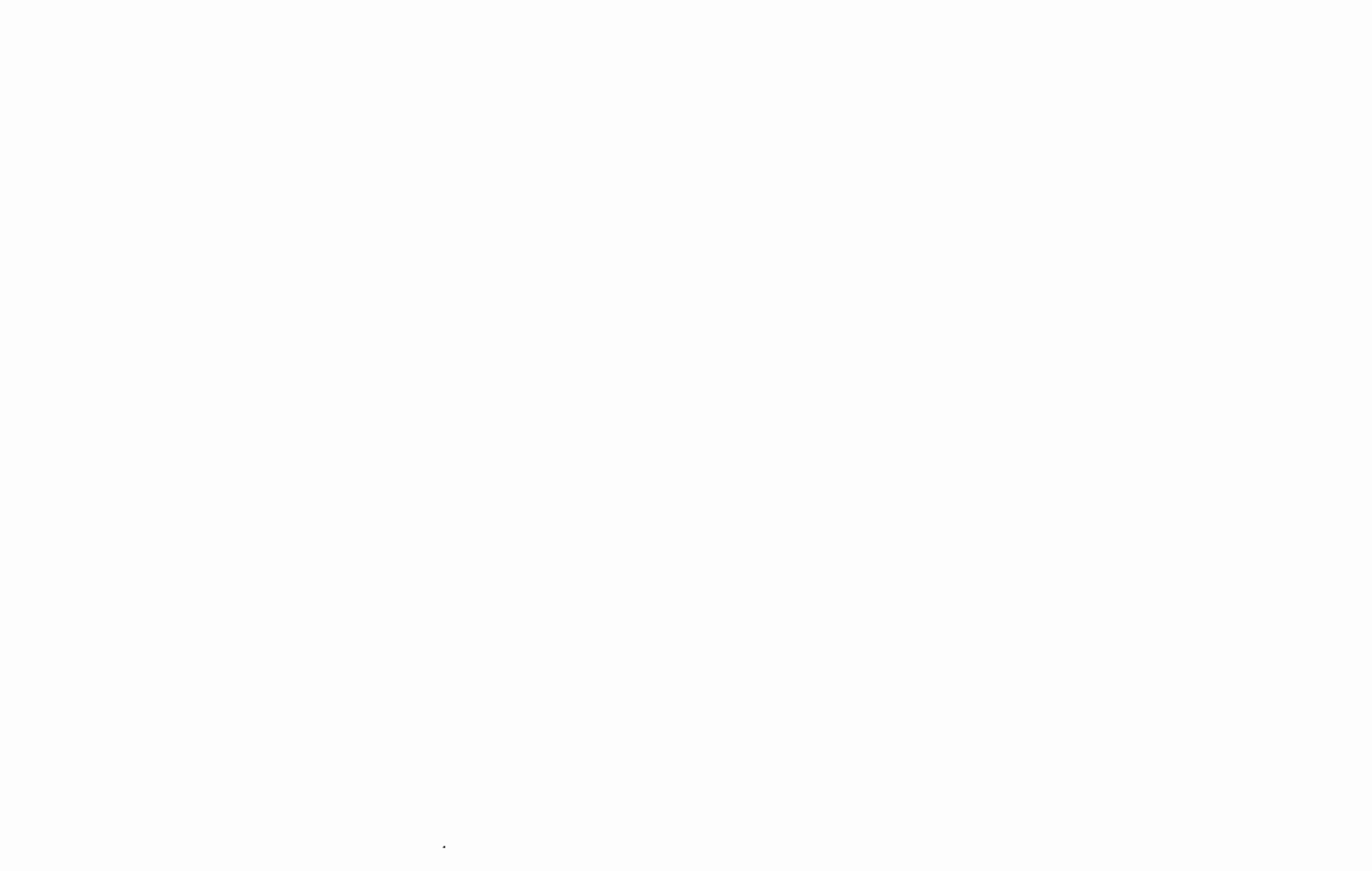


\subsection{Introduction}

In the Netherlands a large number of scientific studies have been performed into the possible impacts of climate change on the Netherlands, as part of the National Research Programme on Global Air Pollution and Climate Change (NOP). One of these reports offers an integrated analysis of the vulnerability for climate change and the adaptation options available to the Netherlands (Van lerland et al., 2001). The section on tourism and recreation in this study is the foundation for this chapter. It gives an overview of the possible effects of climate change for tourism and recreation in the Netherlands, as well as clues for the tourist industry and the government alike to anticipate the changes.

Section two provides a literature review. Section three offers a framework to explore the potential consequences of climate change in a structured way. On the basis of this framework, the impacts for tourism and recreation in the Netherlands are explored in section four and five. Section four focuses on domestic tourism and recreation, while section five addresses outbound tourism. The final section rounds off with the main conclusions.

\subsection{Weather, climate, tourism and recreation}

Although research into the relationship between weather and climate (change) on the one hand and tourism and recreation on the other hand is still in its infancy, the scientific literature does offer some clues for structuring this issue. Abegg et al. (1997) discern four avenues of research into the connection between climate and tourism. Traditional research (1) assumes a stable climate and constant tourist behaviour, so that weather variability and seasonality dominate the analysis. The traditional future projections of tourism (2) take into account all kinds of societal change, but fail to account for a changing climate. Conversely, research that is focused on the physical effects of gradual climate change (3) ignores changes in behavioural patterns. Integrated explorations of the future (4), in which both climate change and changes in the tourist system are incorporated, hardly exist, if at all.

Abegg et al. (1997) indicate that it is difficult to make sensible statements about the influence of climate change without a thorough understanding of the basic relations between climate, weather and tourism. In general, the available resources determine the set of possible recreational and tourist activities (e.g. it takes water to sail), while the weather determines when these activities can best be scheduled (IISD, 1997). The weather for its part depends on seasonal patterns and climate variability. Table 7.1 gives an overview of the weather dependence of a number of recreational activities. 


\begin{tabular}{|c|c|c|c|c|c|}
\hline Type of activity & Temperature & Visibility & Cloud cover & Wind spieed & Precipitation \\
\hline & $\left.1{ }^{\circ} \mathrm{C}\right)$ & $(\mathrm{km})$ & & $(\mathrm{km} / \mathrm{h})$ & \\
\hline $\begin{array}{l}\text { Landscape touring } \\
\text { Summer }\end{array}$ & -11 to 32 & $>5$ & n.a. & $<42$ & $\mathrm{Ni}^{\mathrm{Ni}}$ \\
\hline Passive activities & $>>12$ & $>1.6$ & $<8 / 10$ & $<34$ & Niil \\
\hline Vigorous activities & 13 to 32 & $>3$ & $<8 / 10$ & $<34$ & Niil \\
\hline Whter & 820 & $>1.6$ & $<8 / 10$ & $<25$ & Nil \\
\hline Skating & & & & & Nil or light \\
\hline
\end{tabular}

Table 7.1: Weather sensitivity and outdoor activity

Source: Adapted from Baker and Olssan (1992)

In this context it is useful to make a distinction between tourism and recreation. Although tourists and recreationists often behave similarly (Wall, 1998), there are marked differences in their decision-making processes. Recreationists can respond to the weather conditions on very short notice (IISD, 1997) and quickly adjust their plans. In contrast tourists spend at least one night outside their usual place of residence, according to common definitions of what constitutes a tourist. Therefore, tourists depend on planning for the medium or long range.

Smith (1993) makes a distinction between climate dependent and weather sensitive tourism. In the case of climate dependent tourism, the climate itself attracts visitors who expect favourable weather conditions in their holiday destination. A good example of a region with this type of tourism is the area around the Mediterranean Sea. More than three quarters of the foreign visitors to the Balearics, for example, indicated that the islands' climate was the main motive for visitation (Aguilo et al., 2005). In the case of weather sensitive tourism, the climate is not a tourist attraction in its own right, but weather conditions do play a decisive role when activities are planned (Giles and Perry, 1998; Harrison et al., 1999).

When examining the implications of climate change for tourism, it is useful to make a distinction between indirect effects, through changing attractions, and direct effects, through changes in weather patterns. Coastal erosion and flooding of beaches are examples of the former type of effects. Tourist activities on the beach are hindered by it. In the case of the direct effects, it is important to realise that the current climate is characterised by a high level of variability. Therefore, the analysis should not be limited to changes in mean temperature and precipitation, but also include changes in variability (Abegg et al., 1997). This is particularly true for activities that require little preparation time. After all, the longer a planned holiday and the longer a planning period, the more important climate information is relative to weather forecasts. That is why Wall 
(1998) hypothesises that domestic tourist and recreational patterns are more stable than international ones and that remote destinations are more vuinerable than destinations in the proximity of metropolitan areas. Furthermore, Wall (1998) holds that tourism that is based on natural attractions is more vulnerable than cultural tourism due to indirect effects. Mountainous and coastal regions deserve special attention; because they will be affected by a large share of the changes triggered by alterations in the water cycle.

Using scenario analysis, in chapter 5 the implications of a number of future developments for tourism were explored at a global and continental level. It was concluded that climate change is expected to have a relatively limited influence on the total magnitude of tourism in the world. It will, however, have a significant influence on the distribution of tourism. As a result of climate change, the relative attractiveness of regions will change. The climate of some regions will become more favourable for outside activities; the climate of other regions, on the other hand, will become too hot or too cold. The quality of natural resources and attractions may change as well, for example due to the disappearance of beaches or desertification.

The physical consequences of climate change will trigger human response. However, options to adapt to climate change have thus far received little attention in tourism literature. The few studies that are available approach the issue in an overly mechanistic way, rooted in the natural sciences and lacking insights from the social sciences (Abegg et al., 1997). By leaving out feedback mechanisms and human behaviour, a biased image remains of the effects of climate change. For tourists and recreationists it is usually easy to substitute one destination for another or one activity for another. Tour operators tend to be quite flexible as well. Other segments of the tourist industry, such as hotels and other tourist facilities, are tied to a particular area: invested capital is high and so are sunk costs.

Figure 6.1 in chapter 6 put the direct and indirect effects of climate change in perspective, together with the feedback loops. It showed that climate change affects tourist reality, either directly or through the natural environment, and that this has repercussions for the functioning of social, economic and natural systems. People adjust their behaviour, the tourist industry alters its investment patterns, and nature and the environment adjust to the new distribution of tourist and recreational pressures.

\subsection{RESEARCH METHODOLOGY}

The general insights from the previous section form the basis for the analysis of the possible impacts of climate change in the Dutch context. The expertise and opinions of experts and stakeholders are an additional source of knowledge. At 
the end of the year 2000 a survey was conducted of representatives of the tourist industry, government, and the scientific community. The survey was made up of three sections. The first section addressed the question of what manifestations of climate change (sea level rise, increased mean temperature etc.) were thought to be of most concern for tourism. The second section aimed at eliciting the respondents' thoughts about the importance of climate change relative to other factors such as economic growth and demographic developments. In the third and final section the respondents were asked to come up with options for the tourist system to adapt to climate change.

The results from the survey were discussed during a workshop for stakeholders that was organised in Utrecht, the Netherlands, from 29 to 30 March 2001 (Van lerland et al., 2001). Unlike the survey, the workshop allowed for interaction and in-depth discussions. Because of this, multiple perspectives became visible on important issues such as the relative importance of climate change and the options for and desirability of adaptation. At the same time, the experts could clarify a number of issues, and on most issues a high level of agreement could be reached. Issues that remained controversial are clearly marked in this chapter. A particularly heavily contested issue was whether climate change would have a large effect on outdoor recreation or not.

The research project has made use of scenario analysis, because not only the climate is changing: so are recreation and tourism. The assumption that nothing will change except for the climate is not tenable (Abegg et al., 1997). In fact, the climate is one of the more slowly changing influences on the very dynamic tourist industry. Non-climate factors will surely change the conditions for tourism and recreation, and they will probably do so in unexpected ways, drifting away from historical trends. Scenario analysis is a tool to explore a wide range of possible developments.

Ideally, for an exploration of the future a range of scenarios would be used that are based on a diversity of assumptions. In this way, the user can get some feeling for the range of possible future developments. Such an analysis can form the basis for the development of robust policies, i.e. policies that are effective in all or most scenarios. As a proxy for using a range of scenarios, the NOP project (Van lerland et al., 2001) used an interval of plausible changes in the climate without taking the underlying societal dynamics into account. This approach was justified since the focus was on assessing the impacts of climate change rather than studying societal dynamics. The Royal Dutch Meteorological Institute and the Hadley Institute provided the projections of temperature and precipitations (see Table 7.2). The inputs into their models were supplied by the so-called SRES scenarios that were developed by the Intergovernmental Panel on Climate Change (IPCC) to explore the effects that a range of future 
developments might haven on global climate (IPCC, 2001a). For 2050, both institutes project a temperature increase by one or two degrees. These findings coincide with the results obtained by the IPCC (2001b), where most model and scenario outcomes also fall within the 1-2 degree range. The institutes' projections for precipitation diverge, but the results suggest that the winters will be wetter and the summer somewhat drier.

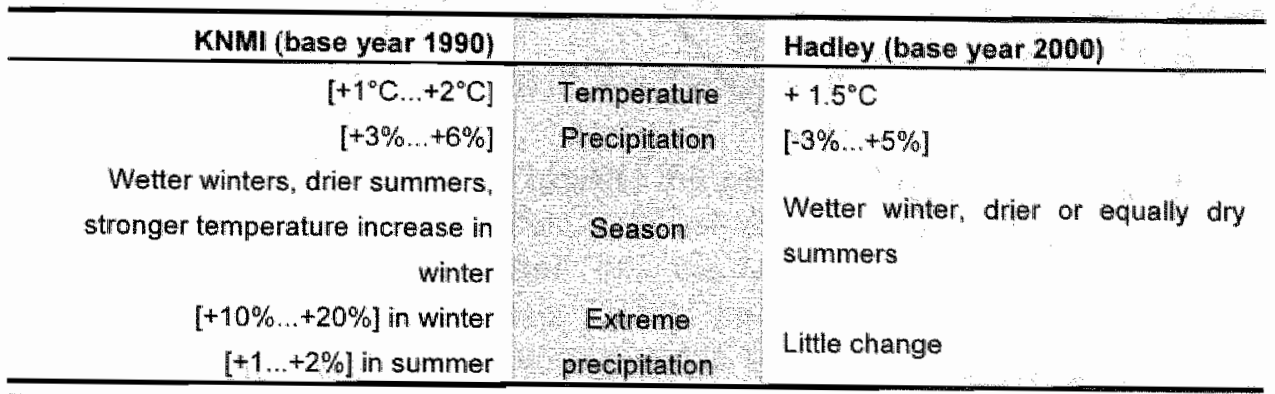

Table 7.2: Climate prognoses for the Netherlands in 2050 according to KNMI and Hadley

Source: Van lerland et al. (2001)

Chapter six used the Tourism Climatic Index (TCl) developed by Mieczkowski (1985) to explore the impacts of climate change on the climatic resources for tourism.

Figure 7.1 depicts the annual TCl distribution for De Bilt for two of the SRES scenarios, namely $\mathrm{A} 1 \mathrm{~F}$ and $\mathrm{B} 1 \mathrm{~A}$. These two scenarios mark the highest and lowest development paths considered by the IPCC (2001a) and in the NOP project, so that a combination of these two scenarios gives an idea of the range of conditions that can be expected. De Bilt is assumed to represent changes in the Netherlands as a whole. In both panels in Figure 7.2, four time slices are represented: 1961-1990 ('1970s', baseline), 2010-2039 (2020s), 2040-2069 (2050s), and 2070-2099 (2080s). All time slices represent thirty-year means and do not reflect any potential changes in the frequency of extreme events. Figure 7.1 clearly supports the prediction of improved climatic conditions in the summer season, and the lengthening of the tourism season. These results are relatively robust.

From April to October, $\mathrm{TCl}$ scores are consistently higher in the $\mathrm{A} 1 \mathrm{~F}$ and $\mathrm{B} 1 \mathrm{~A}$ worlds than in the baseline world. Moreover, a longer period of the year will have $\mathrm{TCl}$ scores of over 60, which is considered the threshold for 'good' conditions, and even $\mathrm{TCl}$ scores of over 70 , which represent "very good" conditions. The main difference between the A1F and the B1A scenarios is the pace of change. In the A1F world, the lengthening of the season will be noticeable by the 2020 s, whereas in the B1A world, noticeable changes are not expected to occur until the 2050 s. 


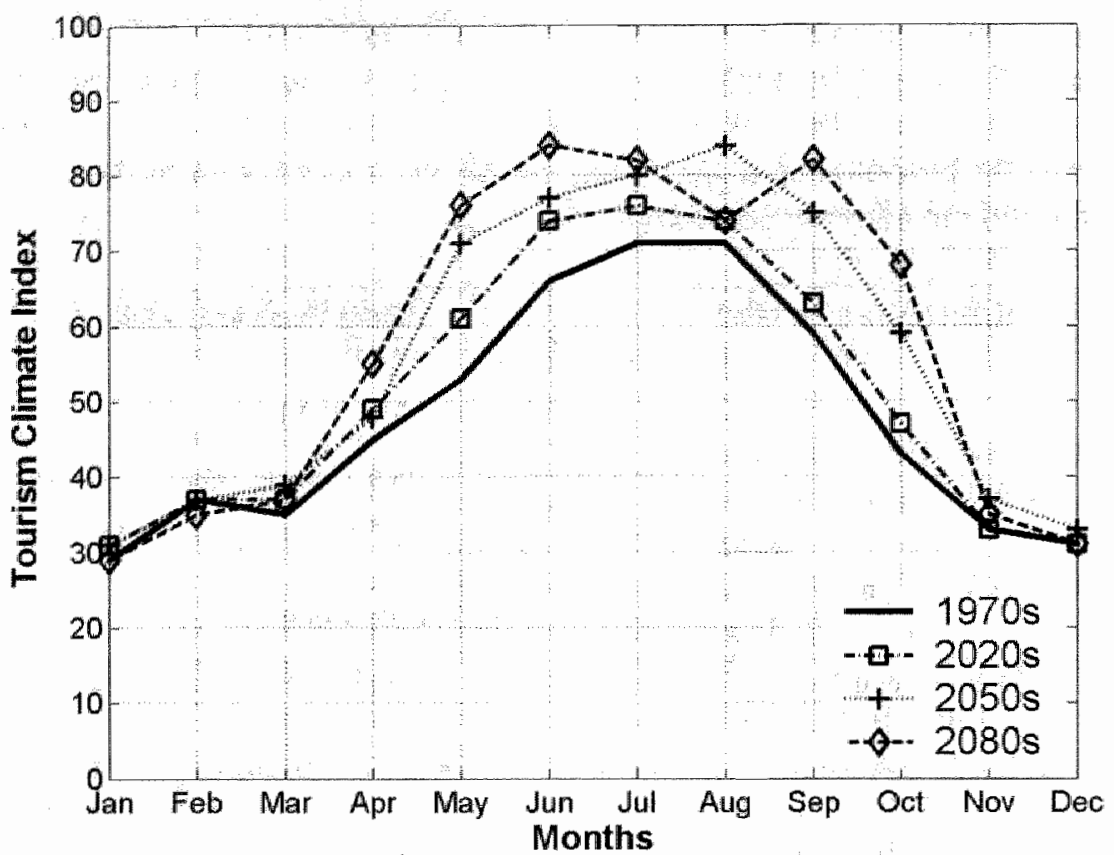

Figure 7.1: Developments in TCl scores for De Bilt (Netheriands) according to the A1F (top) and B1A (bottom) scenarios

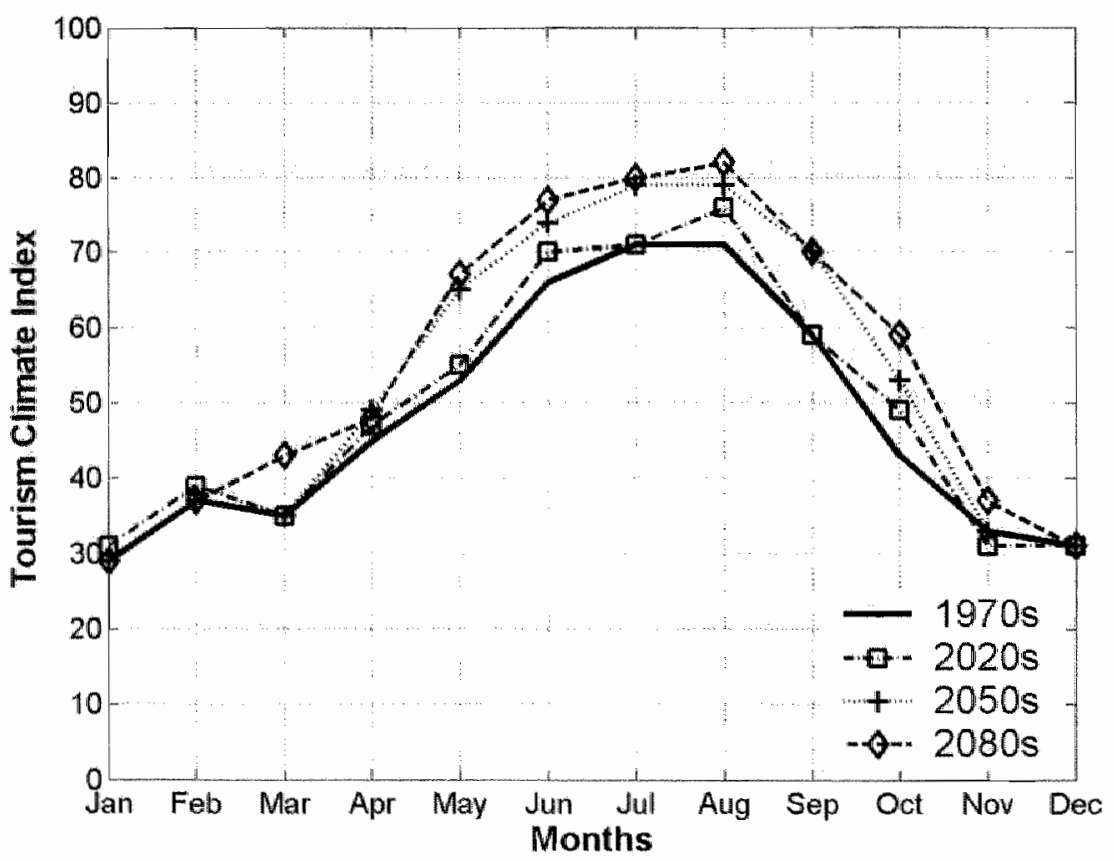


The approach that was taken in the NOP project ignores more dramatic developments, such as a more rapid change in climate due to a reversal of the Gulf Stream or an extensive meltdown of Antarctic ice sheets. Furthermore, the contribution of tourism and recreation to climate change was no object of study, although this contribution is considerable, in particular because of transport emissions (Penner et al., 1999).

\subsection{Effects on tourism and recreation in the Netherlands}

It proved to be inconvenient to classify the effects on tourism and recreation according to the primary manifestations of climate change (sea level rise, temperature change etc.). After all, the impact on tourism of these manifestations is highly dependent on the region and the tourist activity they interact with. Therefore, this section takes the key tourist regions as its point of departure. First, the opportunities and threats are discussed that climate change brings about for tourism and recreation within the Netherlands. Subsequently, the focus is shifted towards the effects on outbound tourism.

In the eyes of foreign tourists, a number of key tourist regions can be discerned within the Netherlands (Marktplan, 1996). Germans have a preference for the coastal zone, the watery districts and the woodlands, the latter of which is also the preferred landscape of the Belgians. In contrast, tourists from other parts of the world are mainly attracted by the historical cities, and by Amsterdam in particular. Not surprisingly, the Dutch discern a larger number of holiday regions than foreign visitors, but the rough classification into four main types of landscape is also useful for the domestic market. Amusement parks are added to the set of landscapes as a type of tourist attractions that is more or less independent from its environment. In short, the impacts of climate change on the following types of landscape are discussed successively: coastal zone, watery districts, woodlands, historical cities and amusement parks.

\subsubsection{COASTAL ZONE}

The most important recreational activity in the coastal zone is sunbathing. The Dutch long and broad beaches are very suitable for this activity but often the weather is not. For sunbathing a sufficiently high temperature and little precipitation are required, and these conditions are rather exceptional in the Dutch climate (see Table 7.1).

Climate change affects seaside recreation both indirectly and directly. Sea level rise damages the beaches as a result of coastal erosion and flooding. Possibly, it will even affect tourist facilities that are situated along the coast. These effects 
are intensified by strong gales that will occur more frequently. As a result, the amounts of damage will increase along with the need for insurance, although the tourist facilites by the sea tend to be low on capital intensity. In a natural setting, the line of dunes would shift inland, but this is nearly ilmpossible in the Netherlands due to the intensive use of the coastal zone. In conclusion, there is a high risk that part of the beaches will be lost, unless costly measures are taken, such as sand suppletion.

Direct results of the temperature increase are an extension of the summer season, a higher probability of pleasant weather for beaching and a higher temperature of the sea. During the NOP workshop a reasonable case was made for the hypothesis that this will be particularly beneficial for day trips, because these are easily adjustable to weather conditions. The vicinity of large numbers of consumers in the Randstad makes this kind of opportunistic behaviour likely. In contrast, the impact on longer stays is probably smaller because the variability in weather conditions remains high, although average conditions improve considerably. Modest changes in demand are also expected for the West Frisian Islands, which are located at a considerable distance from population centres.

As opposed to the positive influence of higher temperatures and an extension of the summer season, climate change causes a negative impact through the increased risk of ultraviolet radiation due to the ozone problem. Climate change hampers the recovery of the ozone layer and ultraviolet radiation causes more damage at higher temperatures. Yet, the fear for skin cancer has so far mainly induced a change of behaviour in tourist destinations rather than a change in destination choice (Perry, 2000a).

\subsubsection{WATERY REGIONS}

As a delta area, the Netherlands is full of suitable waters for water sports, such as the Frisian lakes, the IJsselmeer Lake and the estuaries of Zeelland. The Netherlands disposes of many facilities for water sports, such as yacht-basins and excellent waterways. Water sports and other activities require a certain type of weather conditions, although requirements are less stringent than for seaside activities. It should not be too cold and visibility should be adequate. Extreme weather conditions, such as gales and thunderstorms, are dangerous for water sport enthusiasts.

Similar to seaside activities, water sports will profit from higher temperatures, in particular in relation to an extension of the suitable season. At the same time the risk of accidents and damage will increase due to extreme weather events. Sudden gales and thunderstorms have caused problems in the past and their frequency and intensity will increase (Van lerland ett al., 2001). Perhaps better 
monitoring and early warning systems can reduce the risk of accidents, but it seems more difficult to reduce the damage caused by gales. Insurance premiums can therefore be expected to rise.

The indirect effects of climate change are perhaps even more important for water sports than the direct effects. The discharge of water through the main rivers will increase (Middelkoop et al., 2002), which may have dramatic consequences, as the flooding of the river Maas, and more recently the Elbe and the Danube rivers exemplify. The increased discharge can also cause problems for water sports, for example by damaging capital-intensive facilities, such as yacht-basins (Wall, 1998). On the other hand, significant positive impacts are also expected. The Dutch government is allocating areas of considerable size for water storage and flood prevention (Dutch cabinet, 2005). These new water masses may provide water sports with new opportunities.

Beside water quantity, water quality will be affected by climate change. The increase in temperature fosters the, potentially explosive, growth of dangerous algae and other organisms that make the water unfit for bathing purposes due to health risks.

\subsubsection{WOODLANDS}

For many Dutch people, the woodlands make a welcome change from their daily urban environment. The regions of Drenthe, the Veluwe and Southern Limburg in particular are in high demand by people looking for a place to hike, cycle or relax. These areas have a large number of campings, holiday parks and other facilities. The predominantly light recreational activities demand reasonably high temperatures; little precipitation; good visibility; and little wind (see Table 7.1).

Although the woodlands tend to be situated at moderate distances from the urban centres, the increased frequency of pleasant weather and the extended summer season are expected to induce more day trips to these areas as well. In autumn and winter, conditions deteriorate due to increased precipitation, although this may be partly compensated by somewhat higher temperatures.

Beside these direct effects on tourism and recreation, climate change will affect the woodlands themselves. Influenced by temperature change, areas of distribution of plant and animal life will shift to the north. This movement, however, is hampered by the isolated position of many natural areas that makes migration difficult. Extreme events such as epidemics and forest fires could become decisive factors in shaping the new natural patterns, and their incidence increases. One way or another, it is likely that climate change will affect the landscape, but the impact on recreation and tourism will probably be 
limited, unless the aesthetic vallue of the landscape were to change dramatically.

\section{4 .4 CITIES}

The historical cities in the urban conglomeration of Western Holland (Randstad) attract many domestic and international visitors (Marktplan, 1996). Amsterdam in particular is a popular destination as a result of its cultural and social attractions and facilities. Given the broad range of possible activities in cities, city-based tourism is less sensitive to climate and weather than rural tourism and recreation. Nevertheless, weather and climate do play a role. For outside activities precipitation is undesirable and elevated temperatures can cause heat stress, particularly in cities, where temperature is always a few degrees higher. Moreover, in combination with a lack of wind, heat accelerates the build-up of smog, which makes city trips unpleasant. It is unclear how climate change will affect urban tourist attractions. According to Wall (1998), natural resources are much more vulnerable than cultural resources. Yet, smog and changes in the water cycle may have detrimental effects on the cultural heritage of cities.

The direct consequences of climate change in summer are mainly related to temperature. A higher probability of nice weather could induce a shift towards outdoor activities, and increase the attractiveness of cities for foreign visitors. However, too high a temperature will reduce the attractiveness because of heat stress and smog. In winter increased precipitation may lead to more indoor activities.

\subsubsection{AMUSEMENT PARKS}

Amusement parks form a separate category because of their footloose nature, being relatively independent from geographic circumstances. In the present analysis, the category includes not only theme parks, but also zoos and sports facilities. The only or most important raison d'etre for these parks is tourism and recreation. Amusement parks are usually capital intensive and occupancy levels are therefore critical.

Particularly the amusement parks that offer outdoor activities depend on warm and dry weather. A higher incidence of this type of weather will be highly beneficial to these parks, given their dependence on the opportunistically operating recreationists. Moreover, the extension of the high season will lead to higher levels of occupancy and higher profits. The increased precipitation in winter will increase demand for indoor activities. Amusement parks do not appear to be very vulnerable to the indirect effects of climate change. Perhaps the risk of damage from gales and other extreme weather events will increase somewhat. 


\subsection{Implications for outbound tourism}

The Dutch are very fond of travelling, with holiday participation approaching $80 \%$. They prefer to spend long holidays abroad $(58 \%)$, while staying in their own or neighbouring countries for shorter holidays (78\%). Quietress, relaxation and socialisation are key words for holidays spent in the Netherlands. Important destinations for longer trips are beach resorts, winter sports resorts, natural areas and hibernation areas. In these categories, France, Spain, Germany and Austria are the most popular countries (Van Egmond, 1999). Climate change will affect these destinations and their relative attractiveness. Both the resources that support tourism and the weather conditions needed to use these resources will change. In the following sections, the impacts of both summer resorts and winter destinations are reviewed, with a special emphasis on the Mediterranean countries and the Alps respectively.

\subsubsection{SUMMER TOURISM - THE MEDITERRANEAN}

The countries around the Mediterranean Sea are famous for their beaches and pleasant climate. The average daily temperature is close to the optimal level for tourism of 21 degrees Celsius, as estimated by Lise et. al. (2000). However, the Mediterranean climate also has less pleasant aspects. Frequently, there are heat waves, inundations and gales (Perry, 2000a), the frequency of which will increase due to climate change.

The general expectation is that the holiday areas in the Mediterranean will become warmer and drier. In some parts of the region the high season can even become too hot for beach tourism (Agnew and Viner, 2001; Amelung and Viner, in press; Giles and Perry. 1998; Rotmans et al., 1994).

According to Maddison (2001), the optimal daytime temperature for tourism is around thirty degrees Celsius. A higher temperature soon leads to a reduction in the number of visitors. This effect is enhanced by the growing risk of ultraviolet radiation. On the other hand, a rising temperature will extend the socalled shoulder seasons of spring and autumn. Such a reduction of peak demand in combination with a more equal spread of tourist demand could well improve occupancy levels. Amelung and Viner (in press) found that in the A1F world, the Turkish tourist resort of Antalya would suffer large reductions in scores on the Tourism Climatic Index in summer, while seeing its scores improve in spring and autumn (see Figure 7.2). This pattern is representative for large sections of the Mediterranean regions.

The indirect consequences of climate change for tourism in the Mediterranean are largely rêlated to water or the lack of it. Greater drought will further increase 
water scarcity, fuelling competition between rivalling uses of water (Kent et al, 2002; Perry, 2000a; Viner and Agnew, 1999). Water availability is particularly crucial for tourism, because tourists tend to use much more water than local inhabitants (Gössling, 2002; Wall, 1998). Especially facilities such as golf courses and swimming pools drive up water use very significantly.

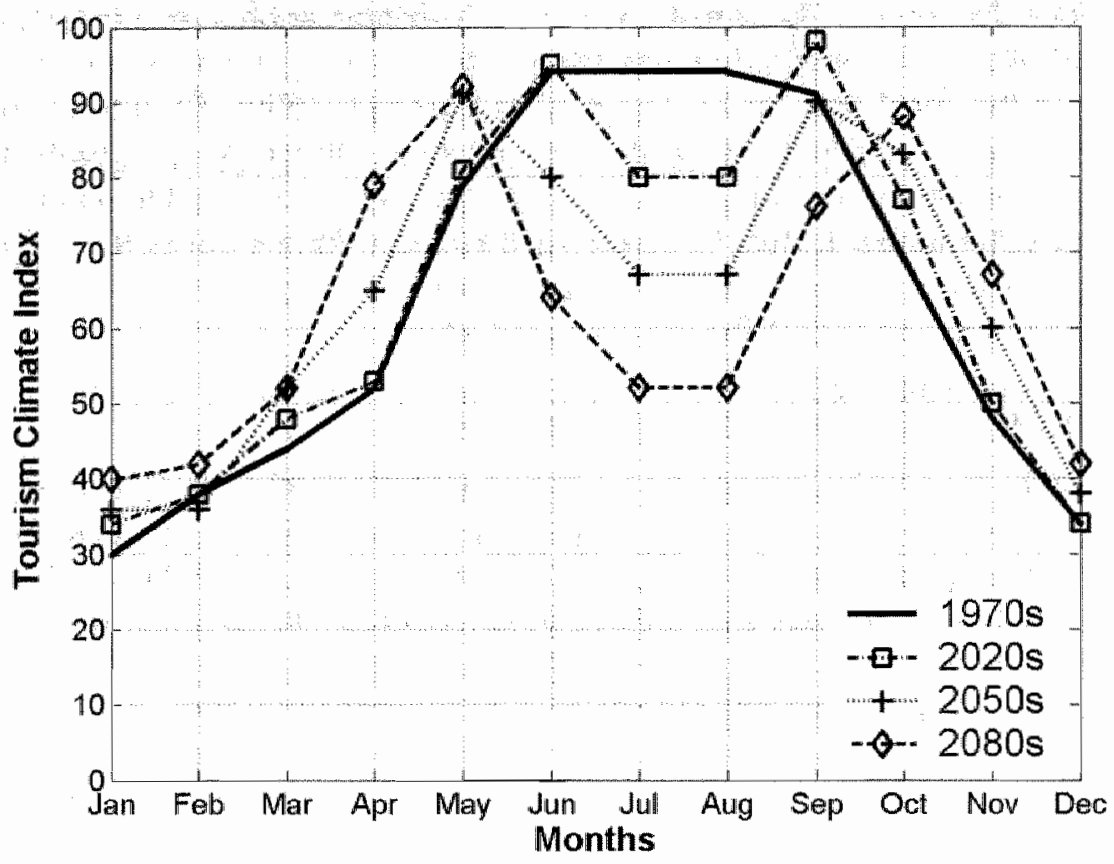

Figure 7.2: Developments in TCI scores for Antalya (Turkey) according to the A1F scenario

Sea level rise, together with the greater frequency of gales strongly increases the risk of coastal erosion and inundations. Furthermore, the rising water temperature will push up the incidence of algal bloom, resulting in poor water quality and health risks. All basic ingredients of beach tourism, i.e. sun, sea and sand, will therefore come under pressure of climate change.

According to calculations by Carter (1991), the zone with an optimal climate for tourism will sharply shift northwards, perhaps as far as the Baltic Sea. In the long run, this area might even become an alternative to the Mediterranean, particularly in the high season. Travel patterns may also change because of an altered balance of domestic and outbound tourism. In the case of countries with a temperate climate such as Germany or the Netherlands, domestic tourism will strengthen its position, as a greater chance of nice weather in summer will reduce the propensity to travel abroad (Hamilton, 2003; Hamilton et al., 2005). According to Lise et al. (2002) demand for domestic tourism in the Netherlands 
goes up by $5 \%$ for every extra degree of temperature, although this effect is partly compensated by more trips abroad in the subsequent year. Research from the United Kingdom suggests that people's holiday planning becomes more spontaneous as temperature and the amount of sunshine increase (Giles and Perry, 1998). Instead of booking a trip to more sunny resorts early in the season; people postpone their decisions until later in the season to see how the weather conditions develop at home. This would further increase the significance of last-minute trips.

\subsubsection{WINTER TOURISM - THE ALPS}

Although in the Netherlands the number of skiers has been declining for years (Van Egmond, 1999), there are still around one million Dutch practitioners of winter sports every year, who predominantly visit the Alps. Snow is the central resource for winter sports, and therefore the guarantee of snow is crucial. In this case, the resource itself is seasonal. As the chances of snowfall are directly linked to air temperature, the availability of snow is generally more secure in higher and colder ski resorts (Harrison et all., 1999). The construction and maintenance of ski runs is expensive and the facilities are capital intensive, which makes the length of the skiing season of utmost importance for the profitability of the industry.

Climate change will almost surely lead to a reduction in the guarantee of snow (Koenig and Abegg, 1997; Viner and Agnew, 1999). There are even clues that this process has already started, because the guarantee of snow has declined markedly since 1982. Schär et al. (1998) estimate that the snow line moves up by 100 to 200 metres for every additional degree of temperature. In addition, a temperature increase will also shorten the skiing season, which will have a detrimental effect on profitability. Some ski resorts may even have to be abandoned. According to Bürki et al. (2003), the percentage of Swiss ski resorts considered snow-reliable would decrease from the current $85 \%$ to $63 \%$ if the snow line would shift by 300 metres, and to $44 \%$ if the shift would be 600 metres.

Chances are that the Dutch skiers will look for alternatives, such as the Scandinavian ski resorts (Perry, 2000b). In Scandinavia, conditions are expected to improve because of climate change. Another possibility is a resurgence of the popularity of hibernating in the Mediterranean region. This phenomenon has recently been losing ground, but climate change may give it a new impetus. 


\subsection{Discussion and conclusions}

Weather and climate are major factors for recreation and tourism, and the impact of climate change may therefore be large. Research into the nature of these impacts is essential to identify options for adaptation and mitigation. It is important to keep in mind that there are many other factors shaping tourism, some of them more decisive than climate change. On a high level of aggregation, the effects of climate change may even be hardly noticeable, but at the level of individual regions and destinations, they undoubtedly will. The extreme weather conditions that have tormented Central Europe in the summer of 2002, and the heat waves of 2003 suggest that these effects may become manifest rather soon. In contrast to the impacts caused by extreme events, those resulting from slower processes such as increasing mean temperature will only become visible in the longer run. However, this latter type of change is be structural and sometimes far-reaching. Rising temperature and water scarcity in the Mediterranean, for example, may considerably reduce the tourist potential in the region. Being a delta area, the Netherlands is also vulnerable to both incidental and structural changes, such as extreme precipitation and sea level rise respectively.

Using scenario analysis as a tool, this chapter presents a first exploration of the opportunities and threats of climate change for tourism and recreation in the Netherlands. Table 7.3 provides a summary of the main findings of this chapter.

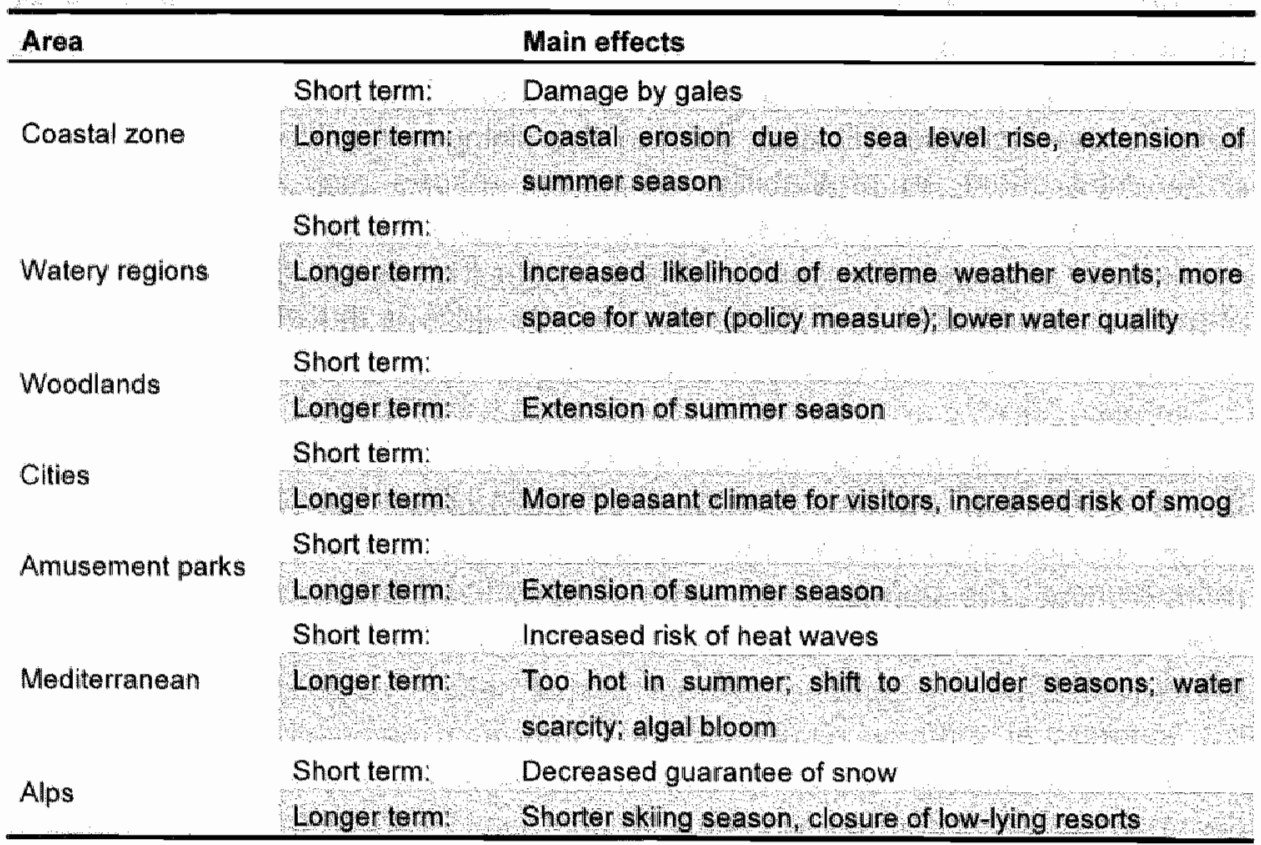

Table 7.3: Summary of the main effects of climate change 
In the Dutch summer, weather will become more attractive for tourism and recreation, although variability remains high. The largest consequences are expected for recreation, because recreationists are able to respond more quickly to changes in weather than tourists. Furthermore, the summer season will become somewhat longer, which improves the profitability of the facilities that rely on outdoor activities. In contrast to the predominantly favourable direct effects of climate change, the indirect effects are strongly divergent. The indirect effects unfavourably affect the coastal zone, while barely influencing recreation in the woodlands and fostering water sports.

With regard to outbound tourism, the popularity of last-minute trips is expected to increase, as the summer season in the Netherlands will on average become longer and warmer. At the same time, the optimal season for tourism in the Mediterranean shifts from the summer to the shoulder seasons of spring and autumn. In summer, the zone of optimal climate for tourism will strongly shift north, towards the Baltic coast. Increasing droughts put additional pressure on the attractiveness of the Mediterranean countries in summer. These developments, if they materialise, could have drastic consequences for the flow of tourists and money across Europe, altering income distribution along the way. It is almost beyond doubt that climate change will be detrimental for the guarantee of snow in the Alps. The resulting shortening of the season and increasing congestion in the fewer remaining resorts will have the winter sports enthusiasts look for alternative regions, such as Scandinavia.

The NOP-report, which forms the basis for this chapter, is just the beginning of research into and discussions about the consequences of climate change for tourism and recreation. One of the main demerits of the current study is that the analysis is based on a rather limited range of possible future developments. Therefore, a recommendation for future studies would be to also incorporate more radical assumptions into the analysis, such as a very rapid change in climate.

Alternatively, the focus could shift from climate change to the vulnerability of the tourist-recreational system. Attention would be fixed on questions such as: what are the ranges of weather and climatic conditions within which tourist activities occur; what climatic boundaries must be respected for the supply of tourist facilities to be profitable; and how much sea level rise can be handled before coastal tourist facilities are threatened? Such a perspective is action-oriented and therefore can easily be connected to the daily reality of the individual actors in tourism. Individual businesses, industry associations and governments can investigate their own dependence on weather and climate, estimate the opportunities and threats associated with climate change and take action accordingly. After all, foresight is the essence of government, and investment. 


\section{References}

Abegg, B., Konig, U., Burki, R. and Elsasser, H. (1997). "Climate Impact Assessment. Im Tourismus." Die Erde, 128(2): 105-116.

Agnew, M. D. and Viner, D. (2001). "Potential Impacts of Climate Change on International Tourism." International Joumal of Tourism and Hospitality Research, 3(1),37-60.

Aguiló, E., Alegre, J. and Sard, M. (2005). "The Persistence of the Sun and Sand Tourism Model:" Tourism Management; 26(2): 219-231.

Amelung, B. and Viner, D. (in press). "Mediterranean Tourism: Exploring the Future with the Tourism Climatic index." Joumal of Sustainable Tourism.

Baker, W. M. and Olsson, L. E. (1992). "Tourism: A Climate-Sensitive Industry." Industry and Environment, 15(3): 9-15.

Burki, R., Elsasser, H. and Abegg. B. (2003). "Climate Change and Winter Sports: Environmental and Economic Threats." Paper presented at the 5th World Conference on Sport and Environment, Turin, 2-3 December 2003 Turijn.

Carter, T. R. (1991). "The Hatch Index of Climatic Favourability." Unpublished mimeo Finnish Meteorological Institute: Helsinki, Finland:

Dutch cabinet (2005). "Planologische Kernbeslissing Ruimte Voor De Rivier." The Hague.

Giles, A. H. and Perry, A. H. (1998). "The Use of a Temporal Analogue to Investigate the Possible Impact of Projected Global Warming on the Uk Tourist Industry." Tourism Management. 19(1): $75-80$.

Góssling, S. (2002). "Global Environmental Consequences of Tourism." Global Environmental Change, 12(4): 283-302.

Hamilton, J. M. (2003). "Climate and the Destination Choice of German Tourists." Working Paper FNU-15 (revised), Research Unit Sustainability and Global Change, Centre for Marine and Climate Research, University of Hamburg: Hamburg.

Hamilton, J. M., Maddison, D. and Tol, R. S. J. (2005). "Climate Change and International Tourism: A Simulation Study." Global Environmental Change, 15(3): 253-266.

Harrison, S. J., Winterbottom, S. J. and Sheppard, C. (1999). "The Potential Effects on Climate Change on the Scottish Tourist Industry." Tourism Management, 20(2): 203-211.

IISD (1997). "The Effects of Climate Change on Recreation and Tourism on the Prairies: A Status Report." International Institute for Sustainable Development: Winnipeg, Canada.

IPCC (2001a). Climate Change 2001: Synthesis Repont, Cambridge University Press.: Cambridge, United Kingdom, and New York, NY, USA.

IPCC (2004b). Climate Change 2001: The Scientific Basis: Contribution of Working Group / to the Third Assessment Report of the Intergovernmental Panel on Climate Change, Cambridge University Press: Cambridge.

Kent, M., Newnham, R. and Essex, S. (2002). "Tourism and Sustainable Water Supply in Mallorca: A Geographical Analysis." Applied Geography, 22(4): 351-374.

Koenig, U. and Abegg, B. (1997). "Impacts of Climate Change on Winter Tourism in the Swiss Alps." Joumal of Sustainable Tourism, 5(1): 46-58.

Lise, W., Spaninks, F. A. and Tol, R. S. J. (2000). "International Tourism." in: Tol, R. S. J. (ed.) Weather Impacts on Natural, Social and Economic Systems in the Netherlands, institute for Environmental Studies: Amsterdam, Netherlands, 13-30.

Lise, W. and Tol, R. S. J. (2002). "Impact of Climate on Tourist Demand." Climatic Change, 55(4): $429-449$. 
Maddison ${ }$ D. (2001). "In Search of Warmer Climates? The Impact of Climate Change on Flows of British Tourists." Climatic Change, 49(1/2): 193-208.

Marktplan (1996). "Naar Een Nieuwe Kijk Op Taeristisch Nederland." Eindrapport Onderzoek Herijking Toeristengebieden Marktplan Adviesgroep BV: Amsterdam.

Middelkoop, H., Kwadijk, J. C. J., Van Deursen, W. P. A. and Van Asselt. M. B. A. (2002). "Scenario Analyses in Global Change Assessment for Water Management in the Lower Rhine Delta." in: Beniston, M. (ed.) Climatic Change: Implications for the Hydrological Cycle and for Water Management. Advances in Global Change Research, Kluwer Academic Publishers: Dordirecht, 445-463.

Mieczkowski, Z. (1985). "The Tourism Climatic Index: A Method of Evaluating World Climates for Tourism." The Canadian Geographer, 29(3): 220-233.

Penner, J. E., Lister, D. H. Griggs, J. D., Dokken, D. J. and McFarland, M. (1999). "Aviation and the Globall Atmosphere: Summary for Policymakers." Special Report of IPCC Working Groups I and III Intergovernmental Panel on Climate Change.

Perry. A. H. (2000a). "Impacts of Climate Change on Tourism in the Mediterranean: Adaptive Responses." 35.2000, Fondazione Eni Enrico Mattei.

Perry, A. H. (2000b). "Tourism and Recreation." in: Parry "M. L. (ed.) Assessment of Patential Effects and Adaptations for Climate Change in Europe: The Europe Acacia Project, Jackson Environment Institute, University of East Anglia: Norwich, UK.

Rotmans, J. Hulme, M. and Downing, T. E. (1994). "Climate Change Implications for Europe." Glabal Enwironmental Change, 4(2): 97-124.

Schär, C., Davies, T. D. Frei, C., Wanner, H., Widmann, M., Wild, M. and Davies, H. C. (1998). "Current Alpine Climate." in: Cebon, P., Dahinden, U., Davies, H. C., Imboden, D. and Jaeger, C. C. (eds.) Views from the Alps, The MIT Press: Cambridge, USA, $21-72$.

Smith, K. (1993). "The Influence of Weather and Climate on Recreation and Tourism." Weather, 48(12): 398-403

Van Egmond, T. (1999). Het Verschijnsel Toerisme; Verleden, Heden En Toekomst, Toerboek: Leiden.

Van lerland, E. C., De Groot, R. S., Kuilkman, P. J., Martens, P., Amelung, B., Daan, N., Huynen, M., Kramer, K., Szönyi, J., Veraart, J. A., Verhagen, A., Van Vliet, A., Van Walsum, P. E. $V$. and Westein, E. (2001). "Integrated Assessment of Vulnerability to Climate Change and Adaptation Options in the Netherlands." 410200 088. Dutch National Research Programme on Global Air Pollution and Climate Change: Wageningen.

Viner, D. and Agnew, M. (1999). "Climate Change and Its Impacts on Tourism", Report prepared for WWF-UK, Climatic Research Unit: Norwich, UK.

Wall, G. (1998). "Implications of Global Climate Change for Tourism and Recreation in Wetland Areas." Climatic Change, 40(2): $371-389$. 


\section{Chapter 8}

Taxing aviation: historical background and future perspectives 


\subsection{Introduction}

Aviation is the fastest growing mode of transport. Since 1960 passenger traffic has grown at nearly $9 \%$ per year (Penner et al., 1999). It is relatively cheap, very fast, and it allows travellers to reach almost any country within one or two days of travelling. Yet, its negative impacts on the environment and society are huge. Gössling et al. (2002) and Gössling et al. (2005) consider air travel to be the most problematic global environmental impact of tourism due to its large contribution to climate change. The Intergovernmental Panel on Climate Change (IPCC) estimated aviation's contribution to radiative forcing at $3.5 \%$ in 1992 (Penner et al., 1999). More recent calculations for 2000 arrived at similar values (Lee et al., 2005). At flight altitude, emissions of $\mathrm{NO}_{x}, \mathrm{H}_{2} \mathrm{O}$, and soot multiply the effects of $\mathrm{CO}_{2}$ by an estimated factor of 2.7, compared to 1.05 for cars (Gössling et al., 2005).

Noise is a major local problem around airports. In an assessment of the health impact of large airports, the Health Council of the Netherlands (1999) concluded that there is sufficient evidence for a causal relationship between environmental noise exposure and hypertension, ischaemic heart disease, severe annoyance, sleep disturbance, and decreased performance of cognitive tasks at school.

The detrimental impacts of international aviation are in sharp contrast with the preferential fiscal treatment it receives. This chapter ${ }^{1}$ examines the historical background of the fiscal treatment of (international) aviation. In addition, it considers options to break out of the institutional lock-in and to restore the balance between aviation's societal contribution and its fiscal treatment.

\subsection{The position of international aviation in international treaties}

\subsubsection{INTERNATIONAL AVIATION AND THE KYOTO PROTOCOL}

The growing evidence for anthropogenic climate change and its detrimental effects on nature and society have led governments to realise that emissions should be mitigated. At the Third Session of the Conference of the Parties in Kyoto in 1997, targets were set for reducing greenhouse gas emissions.

\footnotetext{
'Based on Meijers (2005), a working paper written in the contexı of Daniël Meijers' internship at ICIS, October 2004-February 2005, supervised by the author of this PhD thesis.
} 
Emissions from international shipping and aviation were not included in these targets, despite their considerable and rapidly increasing relevance (Olsthoorn, 2001). The main reason was that difficulties had arisen over the methodologies for allocating the emissions. Five options had been considered (Oberthür and Ott, 1999):

- No aliocation to national inventories:

- Allocation according to the country where the fuel is sold;

- Allocation according to the nationality of the airline or of aircraft registration; and

- Allocation according to the country of departure or destination of the aircraft;

- Allocation according to the country of departure or destination of the passenger/cargo.

No further progress could be made. Each of the options leads to very different allocations of the emissions from international aviation, and the countries to which substantial amounts of emissions would have been allocated, would be seriously disadvantaged. Aviation is a very dynamic and competitive sector, which makes it difficult for governments to implement effective measures to reduce emissions (Oberthür, 2003).

Instead, the International Civil Aviation Organisation (ICAO) was requested to take the initiative and develop plans to reduce greenhouse gas emissions from aviation. Article 2.2 of the Kyoto protocol to the United Nations Framework Convention on Climate Change reads as follows:

\footnotetext{
"The Parties included in Annex I shall pursue limitation or reduction of emissions of greenhouse gases not controlled by the Montreal Protocol from aviation and marine bunker fuels, working through the International Civil Aviation Organization and the International Maritime Organization, respectively."
}

The ICAO and the IMO accepted the invitation, albeit not wholeheartedly. It was virtually impossible to reject the request, and accepting the invitation allowed the organisations to retain their regulatory sovereignty in their respective sectors. However, the request was somewhat foreign to the organisations' prime objectives: the promotion and enhancement of international aviation and shipping, respectively (Oberthür, 2003). This could explain the observation that progress has been very slow (House of Commons Transport Committee, 2003). ICAO has shown a preference for an international open emissions trading scheme, but the mode of allocation of emission allowances still needs to be elaborated. 
At the same time, ICAO has been very active and instrumental in recommending reciprocal tax exemptions for foreign aircraft: In addition, the organisation dismissed international levies and charges, arguing that these are impractical and unwarranted (Oberthür, 2003).

\subsubsection{INTERNATIONAL AVIATION AND TAXATION}

Whereas operators of competing modes of transport, such as trains or coaches, collect value added taxes (VAT) on their sales and pay levies and taxes over their fuel consumption, airline operators are largely exempt from these kinds of charges. These exemptions have been incorporated into most bilateral air transport agreements between countries, which are legally binding. The current standard agreement is the Open Skies agreement, introduced by the United States.

The tax exemptions have substantial effects on the cost structure of the aviation industry and on fiscal revenues. A first impression of the size of the fiscal losses associated with the fuel tax exemption can be found by simply multiplying the total amount of jet fuel sold by a hypothetical fuel tax. The reference tariffs used here are the tariffs charged on car petrol by individual EU countries. For the EU15 in 2002, this calculation is done in Table 8.1. In the table, the jet fuel deliveries for each member state are multiplied by that country"s specific petrol tax. The result for the EU-15 is 33.7 billion euros in unpaid taxes.

\begin{tabular}{|c|c|c|c|}
\hline & $\begin{array}{l}\text { Delliveries } \\
\text { (109 tons) } \\
\text { Kerosene }\end{array}$ & $\begin{array}{c}\text { Levies } \\
\text { (Euros per lon) } \\
\text { Unleaded } \\
\text { petrol }\end{array}$ & $\begin{array}{c}\text { Revenues } \\
\text { (Million Euros) }\end{array}$ \\
\hline Belgium & 1.07 & 638 & 6811 \\
\hline Denimark & 0.75 & 689 & 514 \\
\hline Germany & 6.81 & 785 & 5.348 \\
\hline Greece & 1.14 & 372 & 423 \\
\hline Spain & 4.19 & 498 & 2.087 \\
\hline France & 5.90 & 722 & 4.263 \\
\hline Ireland & 1.47 & 504 & 743 \\
\hline Italy & 3.18 & 682 & 2.170 \\
\hline Luxemburg & 0.36 & 468 & 170 \\
\hline Netherlands & 3.37 & 789 & 2.660 \\
\hline Austria & 0.52 & 52 & 271 \\
\hline Portugal & 0.72 & 603 & 436 \\
\hline Finland & 0.46 & 704 & 324 \\
\hline Sweden & 0.77 & 642 & 497 \\
\hline United Kingdom & 14.08 & 933 & 13,146 \\
\hline EU-15 & 44.81 & 24? & 33.733 \\
\hline
\end{tabular}

Table 8.1: Potential revenues of a fuel levy on kerosene, based on petrol tariffs, for the year 2002

Sources: $\quad$ Siebenaller (2003), ${ }^{2}$ EurActiv (2003) 
This figure represents an upper limit because the introduction of a levy will suppress demand, which is unaccounted for in the calculation. Nevertheless, it is clear that the fiscal benefits are large, in particular when these are compared to the total revenues of European airlines. For the member airlines of the Association of European Airlines (AEA), who use an estimated $56 \%$ of the total intra-EU jet fuel deliveries, these total revenues amounted to 60 billion euros in 2002.

In section 8.5 on future perspectives, the effects of taxation on the air travel market are explored in more detail. At this point, we stop at the conclusion that the tax exemptions have major effects on the development of aviation, and proceed with an investigation of the historical roots of these exemptions. This investigation starts with a review of the history of aviation and its fiscal treatment in the United States of America. Being a world power and a major player in aviation from its early days, the USA has had a major influence on the development of the international aviation standards. In addition, the American federal state has had to resolve domestically many of the cross-border issues, such as the risk of double taxation, that are recurring on the international stage.

\subsection{The cradle of commercial aviation and its fiscal regime: the USA}

In 1903, the Wright brothers made the first motorised flight in history; other pioneers followed suit. The aeroplanes used by these pioneers were manually designed and built, and notoriously dangerous, unreliable and fragile. In the 1920 s, when the quality of the aeroplanes had been improved, the first private aviation companies emerged. The early 1900 s was a period of great changes in transport technologies. Not only had the aeroplane just been invented, the automobile, which was invented in 1885, was also still in its early days of development. These new developments triggered new activities that called for new institutional arrangements.

The advent of the automobile resulted in a greater usage of the highways and in demands for better roads (Tell, 1931). Soon the costs of these new roads became too high to be paid out of the states' general revenues. A license tax was introduced, but soon the revenues from this tax proved inadequate as well. Oregon was the first state to introduce a new gasoline tax of $1 \mathrm{ct}$ per gallon in February 1919 (Cooper, 1933), and by 1929, this example had been followed by 48 other states. The average tax was 3.8 cents for a gallon of fuel (Crawford, 1930), which cost some 21.4 cents at the pump. 
It was considered only just that those who used the roads should be required to pay for them through taxation. Fuel use and road use are not always closely linked, however, as the case of aviation makes clear. The aviation sector protested fiercely against the fuel taxation. It was called "the number one aviation enemy tax" (Hinshaw, 1938). Hainer Hinshaw, the then assistant to the president of United Airlines, used this description in a 1937 speech targeting inequitable taxation at the Seventh Annual Convention of the National Association of State Aviation Officials. To show how inequitable the new fuel tax was, Hinshaw did not only point at the destination of the tax revenues, but also at the fuel use per passenger kilometre, which was much higher for aircraft than for buses:

"The unfairness of requiring the same amount of tax on aircraft fuel as on motor fuel can best be illustrated by comparing the performance data of an average transport plane with that of an average passenger bus. The illustration is made between a thirty-passenger highway bus, powered with a 150 horsepower engine, reputed to travel about ten miles for each gallon of fuel consumed, and a fourteen passenger air liner powered with engines developing two thousand and two hundred horsepower and flying about two miles for each gallon of fuel consumed. Thus, the airliner consumes five times as much fuel as the highway bus to transport 7/15ths as many passengers an equal distance. Or, look at it this way: assuming both transportation units were loaded to capacity, the bus operator can carry thirty passengers ten miles on one gallon of fuel, while the air transport operator would have to use three planes and burn fifteen gallons of gasoline to carry the same number of passengers the same number of miles. Hence, we have tax load ratio of 15 to 1 unfavourable to the air line operator (Hinshaw, 1938)."

Besides the moral and ethical objections against taxing aircraft fuel, there were also legal arguments. The fourteenth amendment of the U.S. Constitution asserts that "a state must have potential jurisdiction over a taxpayer in order to enforce a sales or use tax." It was not obvious that this requirement was met in the case of interstate air traffic. A use tax would have to be levied on an out-ofstate seller, who would be required to collect and remit the proceeds to the taxing state (White, 1980). In addition, a fuel tax seemed to conflict with the Commerce Clause in the U.S. constitution, which guarantees free interstate commerce. Years later, in 1949, the U.S. Supreme Court interpreted this clause as follows: "every farmer and every craftsman shall be encouraged to produce by the certainty that he will have free access to every market in the Nation ${ }^{2}$." No

${ }^{2}$ H.P. Hood \& Sons, Inc. v. Du Mond, 336 U.S. 525, 532, 93 L. Ed. 865, 871 (1949) 
state-imposed measure should cause a business, operated in a remote state, to be more burdened than a comparable business operated in the home state. Thus, an airline flying from one state to another would not need to pay levies on any fuel it takes onboard on fuel stops along the way, because this would obstruct interstate commerce. By 1931 , of 46 reporting states 33 had a standing exemption of refund arrangement for airlines, 11 states did not, and 2 states were unclear (Tell, 1931). The tendency towards tax exemption on aviation fuel continued but never became complete. Several states tax international airlines for the fuel consumed within their territory, which turns out to be legally compatible with the federal government's agreeing not to tax international aviation (see Fucci, 1987 for an elaborate account of this issue).

Among the first commercial uses of aeroplanes was the delivery of mail. After almost a decade of experimentation, the Post Office started a system of scheduled airmail delivery in 1918. Technological improvements continuously increased the speed, range and maximum payload of aeroplanes, but airmail continued to be more costly than rail mail. The Post Office, being a state run enterprise, was able to neutralise this cost difference with subsidies. Private railroad companies felt they faced unfair competition, and filed a successful appeal to the Congress' House Post Office Committee in 1925. The appeal resulted in the Kelly Act on airmail, which compelled the Post Office to subcontract airmail delivery to private aviation firms. Unfortunately for the railroad companies, the new law also fixed the airmail tariffs at below-cost levels. The Post Office would make up for the difference between the tariffs set by law, and the prices charged by airlines. As a result, airmail became even more competitive.

A drawback of the fixed-price system was it removed all incentives for companies to be innovative and ambitious. To the Post Office's great dissatisfaction, network expansion and diversification into passenger transport were no priorities. On the contrary, airmail contractors soon focused on the best-paid routes, picking the shortest distances with the highest earnings. There are even reports of blatant abuse, with airlines sending mail to themselves using registered mail. This type of mail required a heavy lock, which added weight, and thus forced up the cost to the government (Leary, 1985).

Many attempts were made to prevent the abuse of government subsidies, but the essence of the government-run scheme remained intact. The airmail arrangements never stopped progress altogether, however. Eventually, aviation companies started to fly longer routes and to take passengers onboard on mail flights. Passenger transport became an important complementary source of revenue. 
In 1928 the Kelly Act was revised to include foreign mail delivery. Stimulated by this new law and domestic success, American aviation entrepreneurs began to try their luck abroad. The Pan American Airways Corporation (Pan American) acted most aggressively. Its director Juan $T$. Trippe arranged many exclusive contracts with Latin American governments allowing his company to develop an unparalleled empire. Rapidly building up a huge network across Central and South America in the midst of the Depression. Pan American fulfilled all the government's hopes and dreams. By December 1931 Pan American's system covered 21,000 miles, while the American internal airlines flew 30,450. Pan American virtually controlled Latin skies (Miller, 1971).

After the initial period of aggressive expansion, a period of stagnation set in. In the 1930s, Pan American tried to expand into other continents, which met with a variable degree of success. The company also began to show many of the traits ascribed to monopolies: poor schedules, high prices, slow innovation, inefficiency, and high costs. When Pan American finally attracted a Civil Aeronautics investigation in 1939 , observers quickly realised that the system of generous subsidies had fostered inefficient operations and had become counterproductive (Miller, 1971). By the start of the Second World War, the American government was eager to give aviation a fresh start.

\subsection{International developments}

Only in very large countries such as the United States a profitable domestic airline could be established. In smaller countries, the natural scope of the aviation industry was international. As a result, airlines were among the first modern international corporations that had to tackle issues typical for crossborder activities, such as the compatibility of licences and the sovereignty of countries. In 1919, the Paris Convention of Aerial Navigation established coherent international policies for general issues such as the sovereignty of countries' airspace, airworthiness of aeroplanes and pilot licences (Hotchkiss, 1938).

International trade issues such as double taxation and differences in fuel price between countries were being discussed, but not in the context of aviation. For example, the League of Nations committee dealing with double taxation issues in 1925 only addressed shipping (Hund, 1982). This changed in 1928, when the Pan American Convention on Commercial Aviation in Havana concluded: "The airplane, with its speed of operation, has created a situation that cannot be 
treated with existing ideas (Hyzer, 1933):" To fill this void, the convening states ${ }^{3}$ agreed on the following:

"Article 24

The aircraft of one contracting State engaged in international commerce with another contracting state shall not be compelled to pay other or higher charges in airports or airdromes open to the public than would be paid by national aircraft of the State visited, likewise engaged in international commerce.

\section{Article 25}

So long as a contracting State shall not have established appropriate regulations, the commander of an aircraft shall have rights and duties analogous to those of the captain of a merchant steamer, according to the respective laws of each State (Hotchkiss, 1938)."

This last clause is relevant, considering that in those days the merchant marine already enjoyed widespread exemptions from direct taxes in foreign harbours (Hund, 1982). Miller (1971) reports that in 1936 the United States and the United Kingdom reopened negotiations about common rules on aviation"s exemption from taxation. Three years later, the Convention concerning Exemption from Taxation for Liquid Fuels and Lubricants used in Air Traffic was agreed upon in Londion by 47 states. The agreement would never be ratified, however, as a result of the outbreak of the Second World War (Gazdik, 1950).

The war meant a major boost for aviation. The American Air Transport Command (ATC) alone made more than 150 scheduled flights across the Atlantic per week in 1944, whereas in 1939 the total number of transatlantic flights had just been two. Production of aircraft soared and the war made people more accustomed to aircraft and air travel. Roosevelt flew to Casablanca and to Yalta; Churchill to Washington and Caliro (Miller, 1971).

\subsubsection{THE CHICAGO CONVENTION}

Near the end of the Second World War, questions started to arise around the future of aviation. The United States took the initiative and invited delegations from fifty-two nations to the International Civil Aviation Conference, held in Chicago in 1944. The conference resulted in the signing of the Convention on International Civil Aviation (Chicago Convention) ${ }^{4}$. This agreement still is a

\footnotetext{
${ }^{3}$ Argentina, Bolivia, Brazill, Chile, Colombia, Costa Rica, Cuba, Ecuador, Guatemala, Haiti, Honduras, Mexico, Nicaragua, Panama, Paraguay, Peru, Salvador, the Dominican Republic, the United States, Uruguay and Venezuela

${ }^{4}$ Online available at www.ias/.mcgill.ca/airlaw/public/chicago/chicago 1944a.pdf
} 
landmark for international aviation policies, and is considered to be the main reference document for the fiscal treatment of international aviation. The preamble alludes to the conventions" central objective to further peace and cooperation:

\begin{abstract}
"Whereas the future development of international civil aviation can greatly help to create and preserve friendship and understanding among the nations and peoples of the world, yet its abuse can become a threat to the general security; and

Whereas it is desirable to avoid friction and to promote that cooperation between nations and peoples upon which the peace of the worlid depends;

Therefore, the undersigned governments having agreed on certain principles and arrangements in order that international civil aviation may be developed in a safe and orderly manner and that international air transport services may be established on the basis of equality of opportunity and operated soundly and economically:

Have accordingly concluded this Convention to that end."
\end{abstract}

Having emerged from the war as victors, the United States and the United Kingdom played a decisive factor in the conference. The Americans aimed at abolishing the system of subsidies, state planning and guided growth that had worked so well for the development of their 'infant industry' of aviation, but had become obsolete now that the industry had matured. In addition, the United States was aware that their large and modern air fleet was unmatched by any nation and very competitive. The American view of liberalism, fair competition and equal opportunity met resistance from a competing view that originated from the British. The British vision was one of organising international aviation through a state controlled system, in which designated national airlines ('flagcarriers') would be subject to government regulation and control. In the conference's closing speech, the head of the American delegation, Adolf Berle, compared the British search for "order in the air" with the American desire for "freedom in the air" (Miller, 1971).

The Chicago Convention was a compromise between the American and British views. It made the signing of Air Service Agreements compulsory for any two nations that wished to have an air connection between them. At the conference, the International Civil Aviation Organisation (ICAO) was established, which became the international authority for civil aviation. The Convention also provided for the establishment of an International Air Transport Association (IATA) that would set the rates for the air transport between contracting states. One year later, this provision was complied with by founding IATA in Havana. 
With respect to taxation, the Chicago Convention contained a number of regulations:

"Article 24 - Customs duly

(a) Aircraft on a flight to, from, or across the territory of another contracting State shall be admitted temporarily free of duty, subject to the customs regulations of the State. Fuel, lubricating oils, spare parts, regular equipment and aircraft stores on board an aircraft of a contracting State, on arrival in the territory of another contracting State and retained on board on leaving the territory of that State shall be exempt from customs duty "inspection fees or similar national or local duties and charges. This exemption shall not apply to any quantities or articles unloaded, except in accordance with the customs regulations of the State, which may require that they shall be kept under customs supervision.

(b) Spare parts and equipment imported into the territory of a contracting State for incorporation in or use on an aircraft of another contracting state engaged in internationall air navigation shall be admitted free of customs duty, subject to compliance with the regulations of the State concerned, which may provide that the articles shall be kept under customs supervision and control."

These clauses make clear that fuel and other goods that are already onboard are not to be taxed by third states. However, they do not block taxation of fuel, tickets and other goods that are sold and taken onboard in third states.

\subsubsection{THE INTERNATIONAL CIVIL AVIATION ORGANISATION (ICAO)}

Since the Chicago Conference, the International Civil Aviation Organisation (ICAO) has been the key organisation for international civil aviation. In 1947, it became a specialised UN body. The ICAO keeps track of the national and international air regulations, and organises the ICAO Assembly's triennial meetings to discuss the state of affairs in international civil aviation.

ICAO's main objective is the development of "safe, regular, efficient and economical air transport". To further this objective, the ICAO issues regulations, guidelines and recommendations to its member states, regarding taxation and many other issues. The executive committee of the ICAO, the ICAO Council, addressed taxation issues in a 1950 resolution. With reference to the 1939 London convention that was never signed, the ICAO Council argued that it would be practicable and desirable for aviation to follow long standing maritime practice with respect to tax exemptions for fuel and other consumable technical supplies taken onboard in third countries. The guidelines were revised and 
published in 1966 as Doc 8632. After updates that left the essence of the resolution unchanged, the third and latest edition of Doc 8632 was published in 2000. Clause 1 and 3 are the key sections in the context of this chapter:

"1. With respect to taxes on fuel "ubricants or other consumable technical supplies:

a) when an aircraft registered in one Contracting State, or leased on chartered by an operator of that State, is engaged in international air transport to, from or through a customs territory of another Contracting State its fuel, lubricants and other consumable technical supplies shall be exempt from customs or other duties on a recipracal basis, or alternatively, in the cases of fuel, lubricants and other consumable technical supplies taken on board, such duties shall be refunded, when:

[....]

i) the fuel etc. is taken on board for consumption during the flight when the aircraft departs from an international airport of the other State either for another customs territory of that State or for the territory of any other State, provided that the aircraft has complied, before its departure from the customs territory concerned, with all customs and other clearance regulations in force in that territory;

[...]

b) the foregoing exemption being based upon reciprocity, no Contracting State complying with this Resolution is obliged to grant to aircraft registered in another Contracting State or aircraft leased or chartered by an operator of that State any treatment more favourable than its own aircraft are entitled to receive in the territory of that other Statte;

c) notwithstanding the underlying principle of reciprocity, Contracting States are encouraged to apply the exemption, to the maximum extent possible, to all aircraft on their arrival from and departure for other States;

$[\ldots]$

3. With respect to taxes on the sale and use of international air transport:

each Contracting State shall reduce to the fullest practicable extent and make plans to eliminate as soon as its economic conditions permit all forms of taxation on the sale or use of international transport by air, including taxes on gross receipts of operators and taxes levied directly on passengers or shippers (ICAO, 2000)." 
Clause one states that taxation is allowed if the reciprocity requirement is not met, but also urges the contracting states to move towards a situation of tax exemption as quickly as possible. Clause three is the basis for the absence of VAT on tickets for international flights.

However large its importance, Doc 8632 and its precursors are not international treaties to which signatory countries have to adhere. They reflect the ICAO Council's consensus, and can be considered what Gazdik (1950) calls "attempts to create a "semi" multilateral agreement." Individual states are not legally obliged to comply with the ICAO consensus; but to date none of the 188 countries that are party to the Chicago Convention reject the ICAO policy.

\subsubsection{BILATERAL AIR SERVICE AGREEMENTS}

Air Service Agreements (ASAs) are bilateral agreements that regulate air travel between the two contracting states. In $\mathrm{ASAs}_{\text {, }}$ provisions are generally made concerning routes, flag-carriers, tariffs and taxes. At present, around 3,000 Air Service Agreements are in force. A well-known ASA is the one between the United States and the United Kingdom that was signed in Bermuda on 11 February 1946. The Bermuda Agreement ${ }^{5}$ takes the reciprocity requirement one step further by pledging to treat each other's aircraft no worse than the national carriers or the carriers of the most favoured nation. For the United States, this meant a de facto exemption of fuel tax for international aviation. The Bermuda Agreement was a popular model for treaties between other countries due to "its conciliatory nature and somewhat vaguely worded rules" (Diederiks-Verschoor, 2001), and its clauses soon appeared in other ASAs. As a result, the many exemptions and refunds that individual states had introduced unilaterally (see Gazdik, 1950 for an overview) were also available to international operators.

Reciprocity and the most favoured nation principle brought about a tendency towards harmonization of taxation policies, i.e. towards tax exemption. For example, tax exemption was not explicitly formulated in the 1946 Bermuda Agreement and the 1950 ICAO guidelines, but it was in the Air Service Agreement between the United States and the Netherlands that was signed in 1957.

In the early 1990 s, the United States took a next step in the liberalisation of civil air traffic by replacing their ASAs with a more modern type of treaty. The first of these new agreements, which are commonly referred to as Open Skies treaties, was negotiated with the Netherlands in 1992. With respect to taxation, the new agreements did not bring major innovations. The Open Skies initiative sought to promote free determination of capacity without government interference, reduce

${ }^{5}$ Online available at http://www.aviation.go.th/airtrans/airlaw/us-uk.html 
route restrictions, remove the system of double governmental approval of tariffs, facilitate the operation of charter flights, and promote fair and competitive practices by airlines. Once more the United States set the example: in international aviation policymaking. Other countries were quick to incorporate Open Skies-like provisions into their own ASAs.

\subsubsection{DIRECT TAXES ON PROFITS}

Rules for levying and collecting indirect taxes, such as fuel excises and VAT on tickets, were laid down in international aviation agreements, such as the Chicago Convention, the ICAO resolutions, the ASAs, and the Open Skies treaties. How to handle direct taxes on income and property was a more general issue that applied to all international business activities. International negotiations were aimed at removing or reducing double taxation: the phenomenon of people or companies paying the same tax twice because of incompatible taxation systems in different states. For example, country A may tax income whenever it is earned within its territory, while country B may tax income when it is earned by an enterprise with its headquarters in its territory.

The problem of double taxation was already recognised by the League of Nations in 1921 (Hund, 1982) and by the United States around that same time. In an attempt to settle interstate tax issues related to aviation, American courts considered two models that could harmonise taxation across states. Aeroplanes could either be treated as railway carriages, or as seagoing vessels. International raillroads have such assets as roadbeds and stations, and their rolling stock is generally without a "home": it is located somewhere along the route. Ships, on the contrary, usually have no terminal or docks abroad. They do have a homeport, however.

The implications for taxation are as follows. According to the Railroad approach, the value of the physical assets of a corporation is allocated between the jurisdictions concerned on some such basis as track mileage or value of fixed assets. According to the Vessel approach, the authority to impose taxes is left on a reciprocal basis to the State of registration (Gazdik, 1950). The courts in the United States refused to express a clear preference for any of the two appraoch, but the American government and a majority of other countries gradually sided with the Vessel approach. There are two main arguments for preferring the Vessel approach: a theoretical one and a practical one. The theoretical argument is that the profits of an airline are not primarily associated with the loading and unloading of passengers and freight. Rather, they are associated with flying, which is done mainly in international air space. The practical argument is the sheer impossibility to arrive at an acceptable method of dividing profits between the various permanent establishments and the headquarters (Hund, 1982). 
Currently, the Organisation for Economic Cooperation and Development (OECD) is responsible for promoting the international harmonisation of tax regimes. The OECD provides a model convention for countries to use as a basis for their bilateral tax treaties. The section on aviation in the current version of the model convention is clearly based on the Vessel approach; it reads as follows:

"Article 8: Shipping, inland waterways transport and air transport

1. Profits from the operation of ships or aircraft in international traffic shall be taxable only in the Contracting State in which the place of effective management of the enterprise is situated (OECD, 2003)."

The Vessel approach to taxation, as laid down in this model convention, is advantageous to countries that are home to one or several profitable airlines. States that have air connections but no national airlines do not share in the profits . As a result, developed countries are naturally more inclined towards this model of taxation than developing countries (Hund, 1982). These equity considerations are not limited to aviation as similar taxation models apply to most multinational businesses.

\subsection{Future perspectives}

Bilateral treaties have successfully regulated the levying and collecting of direct and indirect taxes on international aviation. In the case of direct taxes such as the ones on airline profits, these treaties allocate the authority to impose taxes. In the case of indirect taxes such as the ones on fuel and tickets, these treaties. amount to full exemption or explicit intentions to that effect. Being based on international agreements, and on strong mechanisms such as reciprocity and the most favoured nation clause, these exemptions are extremely difficult to reverse, even if there are strong economic, ecological and societal arguments to do so.

The ongoing European integration may provide a basis for revisions, however. In 2002, the European Court of Justice gave a verdict on the authority of member states to sign trade related treaties, after a conflict between these member states and the European Commission. The Court ruled that since 1995 the European Commission had been the sole European body authorised to sign treaties on commercial issues, such as Open Skies (see Middeldorp, 2003 for a detailed account). As a result of the ruling, the Open Skies treaties signed by the European member states had to be renegotiated between the European Commission and the United States. These negotiations, which have yet to be 
concluded, are of great significance. The air traffic within and between the European Union and the United States accounts for a significant share of global aviation volumes. A new type of Air Service Agreement may therefore set a new standard for bilateral agreements.

The European Commission possesses a number of unique features that gives it considerable freedom in the negotiations to revise outmoded provisions. The Commission is not a signatory of the Chicago Convention or a member of $I C A O$, and therefore is not bound to any of their regulations. This relative freedom allows the Commission to include provisions that anticipate on a possible future intra-European charge. What such provisions might look like may be inferred from the Memorandum of Understanding that is currently being negotiated between a South American state and the European Union:

"Article 4 - Taxation of aviation fuel

[...]

2. Notwithstanding any other provision to the contrary, nothing in each of the agreements listed in Annex 2 (d) shall prevent Member States from imposing on a non- discriminatory basis taxes, levies, duties, fees or charges on fuel supplied in its territory for use in an aircraft of a designated air carrier of [South American state] that operates between a point in the territory of that Member State or in the territory of another Member State.

3. Notwithstanding any other provision to the contrary, nothing in each of the agreements listed in Annex 2 (d) shall prevent [South American state] from imposing on a non-discriminatory basis taxes, levies, duties, fees or charges on fuel supplied in its territory for use in an aircraft of a designated air carrier of a Member State that operates between a point in the territory of [South American state] and another point in the territory of [South American state] or in the territory of [South American state]."

The content of this Memorandum of Understanding is fundamentally different from that of the Open Skies treaties. Rather than banning or reducing taxation, the contracting states explicitly reserve the right to impose taxes and levies on fuel.

\subsubsection{EXPLORING THE EFFECTS OF REMOVING THE TAX EXEMPTIONS ON FUEL AND TICKETS}

The renegotiations by the European Commission hold out the prospect of normalisation of the fiscal treatment of fuel use and ticket sales. Section 8.2 gave a first-order indication of the fiscal revenues that such normalisation would entail. In this section, the effects of a fuel tax and the levying of VAT on tickets 
are explored in more detail, incorporating the effects of higher prices on demand into the analysis. Please note that this section onlly relates to the harmonisation of the fiscal treatment of international aviation and other forms of internationall and domestic transport. Possible additional policies, e.g. in the context of climate change mitigation, are beyond the scope of this section.

The first step in the exploration of the effects of fiscal normalisation is an assessment of its implications for transport prices. Based on this assessment, the effects on demand, fiscal revenues and $\mathrm{CO}_{2}$ emissions can be calculated. The price level in passenger air transport after fiscal normalisation is conceptualised as follows:

$$
P_{n}=P_{0}+\text { LeVy }+ \text { VAT }
$$

in which $P_{n}$ is the new price level, $P$ o is the old price level, Levy is the fuell levy, and VAT is the valued added tax.

The transport prices $P_{n}$ and $P_{0}$ refer to the average revenues per $1000 \mathrm{~km}$. The price level $P_{0}$ is based on the statistics for the year 2003 published by the Association of European Airlines (AEA, 2004). The AEA encompasses big players such as British Airways, Air France/KLM, Lufthansa, Iberia and Alitalia, but excludes major low cost airlines such as EasyJet and Ryan Air. Price structures differ markedly between the market segments of scheduled domestic, short haul, and long haul traffic, and non-scheduled traffic, so that the effects on each of these segments are analysed separately.

Deciding on the height of the fuel levy and VAT tariff is a matter of politics, which can of course be informed by scientific analysis. The objective of this paper is not to derive optimal levels for these levies and taxes, however. Rather, it aims at sketching a rough picture of the effects of normalising the fiscal treatment of aviation. To this effect, this analysis assumes that the levy on avilation fuel will be brought up to the same level as the levy on gasoline, its counterpart in road transport. Similarly, the analysis assumes that the VAT tariff on tickets will be brought up to the level charged on other luxury products.

Given the strong role of the European Union in creating an opportunity to introduce taxation in aviation, it is assumed that the EU will harmonise the fuel levy and VAT rates by setting them to the lowest rates charged in the EU-15 of 2003. In that year. Luxembourg had the lowest standard VAT rate, equalling $15 \%$, while Greece had the lowest petrol tax, charging 296 euros per 1000 litres, which corresponds to 372 euros per ton. Fuel use is not reported on by AEA, but based on chemical regularities an estimate can be inferred from the amount of $\mathrm{CO}_{2}$ emitted per passenger $\mathrm{km}(\mathrm{pkm})$ as estimated by Gössling et al. 
(Gössling et al., 2005). The $0.12 \mathrm{~kg} \mathrm{CO}$ per pkm they derived for long haul flights corresponds to $38 \mathrm{~kg}$ of jet fuel per $1000 \mathrm{pkm}$ the $0.14 \mathrm{~kg}$ of $\mathrm{CO}_{2}$ for short haul flights corresponds to $44 \mathrm{~kg}$ of jet fuel per $1000 \mathrm{pkm}$. Based on these figures, the values for the variables Levy and VAT in equation 1 are known, and Pn can be calculated. An overview of the estimated per pkm costs before and after fiscal normalisation is presented in Table 8.2.

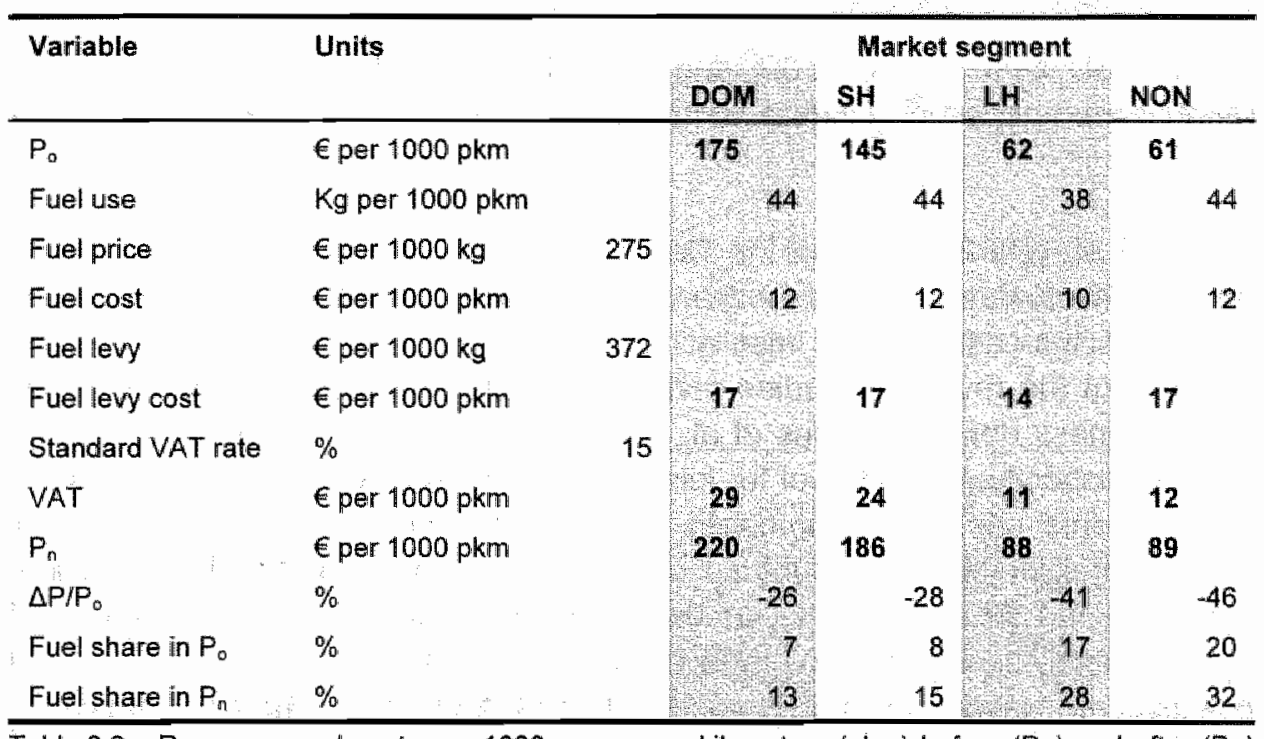

Table 8.2: Revenues and costs per 1000 passenger kilometres ( $\mathrm{pkm}$ ) before (Po) and after ( $\mathrm{Pn})$ subjecting the domestic (DOM), short haul (SH), long haul (LH) and non-scheduled (NON) segments of aviation to a fuel levy and VAT on tickets.

The table shows that in the absence of fuel tax and VAT exemptions, prices would be up by $26 \%$ for domestic flights, and $46 \%$ for non-scheduled flights. The disproportionally large impacts on the prices for long haul and nonscheduled flights result from the relatively large share of fuel costs in their total costs is relatively large. In 2003, average fuel costs were an estimated 10 euros per $1000 \mathrm{pkm}$ for long haul flights, and 12 euros per $1000 \mathrm{pkm}$ for the other segments, based on the average fuel price of 275 euros per ton that was paid by KLM in 2003 (KLM, 2004a; 2004b). Expressing these fuel costs as fractions of total revenues yields values ranging from $7 \%$ for domestic traffic to $20 \%$ for non-scheduled (i.e. chartered) traffic, with an average of $12 \%$. Under the assumption that in the notoriously competitive aviation industry total costs approximate total revenues, this share is within the $8-13 \%$ range that Olsthoorn (2001) presents for the usual share of fuel costs in total airline costs.

The translation of cost and price changes into shifts in demand requires information about the sensitivity of (potential) passengers for price changes, i.e. 
information about their price elasticity. The demand response can be expressed ass:

$$
\frac{\Delta D}{D_{0}}=e \cdot \frac{\Delta P}{P_{a}}
$$

or

$$
\Delta D=e \cdot \frac{\Delta P}{P_{0}} \cdot D_{o}
$$

in which $\triangle D$ is the change in demand, Do is the original level of demand, i.e. the number of passenger kilometres travelled in 2003, and $e$ is the demand elasticity.

Brons et al. (2002) reviewed the literature on price elasticities of demand for passenger ailr travel. They found an average elasticity of -1.15 , which means that a $1 \%$ increase in price results in a $1.15 \%$ decrease in demand. A metaanalysis of the reviewed studies revealed that leisure demand is more elastic than business demand (Brons et al., 2002), with elasticity values close to -1.4 and -.8 respectively. Air travel for leisure purposes accounts for more than half of the global passenger kilometres flown, and even for 70 to $80 \%$ of total passenger kilometres in countries such as Germany and the UK (Gössiling, 2002). In the AEA statistics, no distinction is made between business and leisure travel, so that the average elasticity value is used in the subsequent calculations. Nevertheless, it is good to keep the difference between business and leisure travellers in mind when assessing the results. Table 8.3 gives an overview of the estimated changes in demand.

\begin{tabular}{lccccc}
\hline Variable & Units & \multicolumn{3}{c}{ Market segment } \\
& & DOM & SH & LH & NON \\
\hline$\Delta \mathrm{P}^{\prime} \mathrm{P}_{6}$ & $\%$ & -26 & -28 & -41 & -46 \\
$\Delta \mathrm{D} / \mathrm{D}_{0}$ total & $\%$ & -30 & -32 & -47 & -53 \\
$\Delta \mathrm{D} / \mathrm{D}_{0}$ leisure & $\%$ & -36 & -39 & -58 & -65 \\
$\Delta \mathrm{D} / \mathrm{D}_{6}$ business & $\%$ & -21 & -22 & -33 & -37 \\
\hline
\end{tabular}

Table 8.3 Change in total, leisure, and business demand for air travel, resulting from normalisation of the fiscal treatment of the aviation sector in 2003

The table shows that the preferential fiscal treatment of aviation has very large implications for the demand for air transport. Without these fuel tax and VAT exemptions in place, demand in 2003 would have been an estimated $30 \%$ lower for domestic flights, and some $53 \%$ lower for non-scheduled flights. This latter figure in particular may in reality be considerably higher still, because chartered (i.e. non-scheduled) flights are used almost exclusively for tourism purposes. 
Applying the elasticity value for leisure value to the price increase for chartered flights results in an estimated demand reduction of around $65 \%$.

The impacts that fiscal normalisation would have on fiscal revenues and $\mathrm{CO}_{2}$ emissions are directly linked to changes in demand. Revenues from the fuel levy and the VAT tax on tickets are calculated with the following equations:

$$
\begin{aligned}
& R_{\text {ievy }}=\left(D_{o}+\Delta D\right) \cdot \text { LeVy } \\
& R_{\text {WAT }}=\left(D_{o}+\Delta D\right) \cdot V A T
\end{aligned}
$$

in which $R$ represents revenues.

Table 8.4 gives an overview of the impact of fiscal normalisation on fiscal revenues. The amount of unpaid fuel tax added up to an estimated 5.4 billion euros in 2003 for the AEA members, while the total value of the VAT exemption was an estimated 6.1 billion euros.

\begin{tabular}{llrrrrrr}
\hline Variablle & Units & \multicolumn{4}{c}{ Market segment } \\
& & Total & DOM & SH & LH & NON \\
\hline Fuel levy revenues & Millions of euros & 5,430 & 6,600 & 1,769 & 2,909 & 152 \\
VAT revenues & Millions of euros & 6,085 & 1,041 & 2,592 & 2,345 & 107 \\
Total tax revenues & Millions of euros & 11,515 & 1641 & 4361 & 5254 & 259 \\
\hline
\end{tabular}

Table 8.4 Estimated tax revenues, resulting from normalisation of the fiscal treatment of the aviation sector in 2003

The effects of fiscal normalisation on the $\mathrm{CO}_{2}$ emissions of aviation and their climate forcing potential are represented by equation 8.5 and 8.6 respectively.

$$
\begin{aligned}
& M_{\mathrm{CO}_{z}}=\Delta D \cdot E_{\mathrm{CO}_{2}} \\
& M_{\mathrm{CO}_{2} \text {, }}=M_{\mathrm{CO}_{2}} \cdot F
\end{aligned}
$$

in which $\mathrm{M}$ is the amount of $\mathrm{CO}_{2}$ emissions mitigated, $E$ stands for the emissions per pkm, $\mathrm{M}_{\mathrm{CO2}-\mathrm{eq}}$ is the amount of $\mathrm{CO}_{2}$ equivalents mitigated, and $\mathrm{F}$ is the climate forcing potential per ton of $\mathrm{CO}_{2}$ emitted.

Gössling et al. (2005) estimate the value of $E$ at $0.12 \mathrm{~kg}$ per $\mathrm{pkm}$ for long haul flights, and $0.14 \mathrm{~kg}$ per pkm for shorter flights. The total forcing potential per $\mathrm{kg}$ of $\mathrm{CO}_{2}(\mathrm{~F})$ is an estimated $2.7 \mathrm{~kg}$ of $\mathrm{CO}_{2}$ equivalents, compared to $1.05 \mathrm{~kg}$ for ground transport (Gössling et al., 2005). Burning jet fuel at high altitudes does not only produce $\mathrm{CO}_{2}$ but also other gases, soot and, most importantly, water vapour. This water vapour forms contrails that are believed to add considerably 
to radiative forcing (IPCC, 2001). The impacts of the preferential fiscal treatment of avlation on $\mathrm{CO}_{2}$ emissions are summarised in Table 8.5 .

\begin{tabular}{|c|c|c|c|c|c|c|}
\hline \multirow[t]{2}{*}{ Variable } & \multirow[t]{2}{*}{ Units } & \multirow[b]{2}{*}{ Total } & \multicolumn{4}{|c|}{ Market segment } \\
\hline & & & Dom & SH & LH & NON \\
\hline Emissions before & Miton $\mathrm{CO}_{z}$ & 78.7 & 72 & 22.1 & 46. & 2.7 \\
\hline Emissions after & Mton $\mathrm{CO}_{2}$ & 45.9 & 51 & 15.0 & 24.6 & 1.3 \\
\hline \multirow[t]{2}{*}{ Change } & Mton $\mathrm{CO}_{2}$ & -32.8 & 21 & -7.1 & 221 & -1.4 \\
\hline & Mton $\mathrm{CO}_{2, \mathrm{eq}}$ & -886 & 5.8 & -19.2 & -597 & -3.9 \\
\hline
\end{tabular}

Table 8.5 Estimated change in $\mathrm{CO}_{2}$ emissions, resulting fram normalisation of the fiscal treatment of the aviation sector in 2003

In 2003, the tax exemptions resulted in an estimated 'excess' production of 235 billion pkm by the AEA members, resulting in excess emissions amounting to an estimated 32.8 megatons of $\mathrm{CO}_{2}$, or 89 megatons of $\mathrm{CO}_{2}$ equivalents. For comparison: Greece emitted an estimated 135 megatons of $\mathrm{CO}_{2}$ equivalents in 2002 (EEA, 2004).

While the above analysis is crude and the results are imprecise, the calculations yield a number of interesting findings. To start with, the tax exemptions in the aviation industry result in a multi-billion euro EU-wide fiscal loss, which must somehow be compensated by higher tariffs in other sectors of the economy. The aviation industry greatly benefits from the fiscal arrangements. Without the exemptions, the aviation industry would probably be tens of percents smaller, at least in Europe. The low-cost carriers were not part of the analysis, but the high sensitivity of chartered flights to price changes suggests that they too probably owe a significant share of their success to the tax exemptions. The current favourable position of the aviation industry comes at the expense of other segments of the transportation industry, such as bus and train services. In particular on medium distances, these alternative transport modes are outcompeted by cheap airline services.

The preferential fiscal treatment of aviation also has a clear ecological effect. As a result of the tax exemptions, the AEA member airlines arguably emit an additional amount of $\mathrm{CO}_{2}$ equivalents that is comparable to the total emissions of a small or medium-sized European country. It is likely that the market distortion (injuring the competitive position of other transport modes) introduced by the tax exemptions has resulted in a more carbon-intensive economy. The amount of $\mathrm{CO}_{2}$ equivalents per unit of revenue is $1.38 \mathrm{~kg} / €$ among the AEA member airlines, which is higher than the global average of $1.18 \mathrm{~kg}$ per $€$ of GDP (Gössling et al., 2005). Without a doubt, the excess demand for air services also results in excess production of noise and air pollution, and their 
accompanying serious health effects (Health Council of the Netherlands 1999 ), and in excess claims on land for air travel related infrastructure and facilities.

\subsection{Discussion and conclusions}

The results discussed above indicate that the effects of the tax exemptions in the aviation sector are substantial. The analysis provides arguments for normalising the fiscal treatment and for moving towards a more level playing field for the (international) transport market. The analysis also shows that any attempt towards normalisation is destined to meet fierce resistance. The ICAO has so far actively pursued an ideal of full tax exemptions for aviation throughout the world. At the same time, the ICAO has chosen a very passive interpretation of its task to develop policies to mitigate greenhouse gas emissions by aviation. Allegedly, the allocation of emissions to individual states is virtually impossible, because these emissions are linked to flying in international air space. Interestingly, a very similar argument was used to reject the Railroad approach to taxing profits, and to prefer the Vessel approach. Since fuel use, emissions and profits are all directly linked to the act of transportation and the number of kilometres travelled, it is difficult to see why the same model for taxation could not be applied.

With respect to the taxation of fuel and the levying of VAT, developments in the European Union in recent years hold out the prospect of fiscal normalisation. Still, it is one thing to cancel the ban on taxation; effectively starting to levy taxes is another: There is a strong international tendency towards harmonisation of aviation policy. Therefore, it would be highly desirable if large aviation-entities, such as the European Union, the United States and the Asian aviation giants, would take the lead and commence charging airlines uniformly. If such harmonisation does not materialise, it is not unimaginable that the international community will cling to the zero-tax rates, even though there is no more legal obligation.

It is highly unlikely that fuel taxes or VAT tariffs on tickets comparable to the ones discussed would be introduced at once. Sudden introduction of sizeable fuel taxes and VAT tariffs would have very large impacts on the aviation sector and its suppliers and customers. It is much more likely, and preferable in many respects, that the introduction will take place step-wise. By gradually harmonising the fiscal treatment of aviation with that of other economic activities, major economic and social disruption can be avoided while moving towards a more socially, ecologically and economically acceptable for of aviation. 


\section{References}

AEA (2004). "Summairy of Traffic and Airlines Results." Association of European Airlines: Brussels.

Brons $_{i}$ M. Pels, E., Nijkamp, P. and Rietveld, P. (2002). "Price Elasticities of Demand for Passengler Air Travel: A Meta-Analysis." Journal of Air Transpont Management, 8(3): 165-175.

Cooper, J. C. Jr. (1933). "Some Legall Aspects of Gasoline Taxation as Affecting Aviation." Journal of Air Law, pg. 17-28.

Crawford, F, G. (1930). The Administration of the Gasoline Tax in the United States, Municipal Administration Service: New York City.

Diederiks-Verschoor, I. H. P. (2001). An Introduction to Air Law, Kluwer Law International: The Hague.

EEA (2004). "Annual European Community Greenhouse Gas Inventory 1990-2002 and Inventory Report 2004." European Environment Agency: Copenhagen.

EurActiv (2003). "Fuel Taxation: Policy Summary." Electronic document accessed on 25 August 2005: http:/www euractiv. com/Article?tcmuri=tcm:29-117495-16\%20\&type=LinksDossier.

Fucci, F. R. (1987). "Allowing State Taxation of Foreign Carrier's Fuel: Wardair Canada, Inc. V. Florida Department of Revenue." The Tax Lawyer, 40(419).

Gazdik, J. G. (1950). "Multiple Taxation - Preliminary Notes on Undue Taxation of Airlines and a General Review of Possible Means of Relief." IATA bulletin, 11: 63-70.

Gössling, S. (2002). "Global Environmental Consequences of Tourism." Global Environmental Change 12(4): 283-302.

Gössling, S., Peeters, P. Ceron, J.-P., Dubois, G. Patterson, T. and Richardson, R. B. (2005). "The Eco-Efficiency of Tourism.." Ecological Economics (in press).

Health Council of the Netherlands (1999). "Public Health Impact of Large Airparts." Health Council of the Netherlands: The Hague.

Hinshaw, H. (1938). "The Protection of Aviation from Inequitable Taxation." Address presented at the Seventh Annual Convention of the National Association of Sitate Aviation Officials.

Hotchkiss, H. G. (1938). A Treatise on Aviation Law, Giving Authorities with Complete Citations of Federal and State Decisions and Including Texts in Full of the International Convention of 1919, the Havana Convention, the Warsaw Convention, the Civil Aeronautics Act of 1938, Air Commerce Act of 1926, and Other Laws, Federal and State, Relating to Aviation, Baker Voorhis: New York.

House of Commons Transport Committee (2003). "Aviation: Sixth Report of Session 2002-03, Volume I." House of Commons: Landon.

Hund, B. (1982). "The Development of Double Taxation Conventions with Particular Reference to Taxation of International Air Transport." International Bureau of Fiscall Documentation: Amsterdam.

Hyzer, L. (1933). "Pan American Air Regulation: A Comparative Study." Journal of Air Law, 4: 531 557.

ICAO (2000). "Icao"s Policies on Taxation in the Field of International Air Transport; Doc. 8632." International Civil Aviation Organisation: Montreal.

IPCC (2001). Climate Change 2001: Synthesis Report, Cambridge University Press.: Cambridge, United Kingdom, and New York, NY, USA.

KLM (2004a). "Financial Statements to the Annual Report 2003/2004." KLM Royal Dutch Airlines: Amstelveen.

KLM (2004b), "Sustainability Report 2003/2004: Cooperating for Sustainability." KLM Royal Dutch Airlines: Amstelveen. 
Leary W. M. (1985). Aerial Pioneers - the U.S. Air Mail Service, 1918-1927, Smithsonian Institution Press: Washington, D.C.

Lee, D. S., Lim, L. L. and Raper, S. C. B. (2005). "The Role of Aviation Emissions in Climate Stabilization Scenarios. Poster Presented at the Symposium Avoiding Dangerous Climate Change, Convened By the Met Office, 1-3 February 2005." Exeter.

Meijers, D. (2005). "Tax Flight: An Investigation into the Origins and Developments of the Exemption from Various Kinds of Taxation of International Aviation." International Centre for Integrative Studies: Maastricht.

Middeldorp, G., \& Van Ooik, R. H. (2003). "Van Vercleellde Open Skies Naar Een Uniform Europees Extern Luchtvaartbeleid." Nederlands tijdschrift voor Europees recht, $9(1 / 2): 1-10$.

Miller "J. A. (1971). "Air Diplomacy: The Chicago Civil Aviation Conference of 1944 in AngloAmerican Wartime Relations and Post-War Planning", Yale: New Haven.

Oberthür, S. (2003). "Institutional Interaction to Address Greenhouse Gas Emissions from International Transport: Icao, Imo and the Kyoto Protocol." Climate Policy, 3(3): 191-205.

Oberthür, S. and OH, H. E. (1999). The Kyoto Protocol. International Climate Policy for the 21st Century, Springer: Berlin.

OECD (2003). "Oecd Model Tax Convention." Organisation for Economic Cooperation and Development: Paris.

Olsthoorn, X. (2001). "Carbon Dioxide Emissions from international Aviation: 1950-2050." Journal of Air Transport Management, $7(2): 87-93$.

Penner, J. E. Lister, D. H., Griggs, J. D. Dokken, D. J. and McFarland, M. (1999). "Aviation and the Global Atmosphere: Summary for Policymakers." Special Report of IPCC Working Groups I and III Intergovernmental Panel on Climate Change.

Siebenaller, E. (2003). "Intra-Eu Deliveries of Petroleum Products in 2002." Eurostat: Brussels.

Tell. W. K. (1931). "Taxation of Aircraft Motor Fuel." Journal of Air Law, 2: pg. 342-355.

White, R. C. (1980). "State Sales and Use Taxes - Variations, Exemptions, and the Aviation Industry." Journal of Air Law and Commerce, 45: pg. 509-557. 
$\therefore \quad \because \quad \because$

$\cdots$

$\therefore \ldots$ 
Chapter 9

Discussion and conclusions 



\subsection{Objectives}

Holidaymaking is a popular activity. Every year, hundreds of millions of tourists travel abroad in search of sea and sun, peace and quiet, or culture, while even more tourists spend their holidays in their home countries. Tourism has been a booming business for at least sixty years. Currently, the sector contributes around $10 \%$ to global GDP and employment. There is a drawback to tourism's successes, however. The scale and growth of the phenomenon make it difficult to manage its negative effects. The marked spatial concentration of tourism in large resorts, and the concentration of activities in a brief holiday season add to the problems.

In light of the current state of tourism and the existence of forecasts indicating continued strong growth in the future, there is widespread uneasiness about the future of tourism. The central aim of this thesis was to explore various possible futures of tourism and their implications for the future scale and distribution of tourism. In Chapter 1 the core research question was formulated as follows:

In what different ways might the determinants of tourism develop in the coming decades, and what would this imply for the global scale and distribution of tourism?

This question was split up into four sub-questions.

1. Which are the main historical and current determinants of tourism, and what seasonal and geographical tourism patterns have they brought about?

2. How might these patterns change over the next decades?

3. What is the potential impact of climate change on tourism patterns around the world, and in the Netherlands in particular?

4. What are the potential effects on tourism demand of abolishing the current tax exemptions on aviation fuel and tickets?

These questions were addressed in successive parts of this thesis. The main conclusions from and a reflection on each of these parts are described below, a discussion of promising future research directions.

\subsection{Conclusions and reflection}

\subsubsection{TOURISM DEVELOPMENT IN RETROSPECT}

Tourism increased by a factor of thirty between 1950 and today. No single factor can explain this enormous increase; a variety of interrelated 
developments have contributed to it: population growth, economic development, the advent of consumerism, relative geopolitical stability, increased international trade, the development of the jet enigine, and the emergence of the Internet are a few important factors. In the western world, these interconnected developments have democratised tourism and produced a transition from a state of upper-class tourism to a leisure society, in which tourism is an integral component of everyday life. This situation has certainly not yet been reached everywhere. The traditional markets of Europe and North America still account for around two thirds of total international tourists, although in particular the newly industrialising countries in Asia are catching up fast (UNWTO, 2006), moving towards a leisure society.

The sheer volume of global tourism has started to cause problems on a global scale. Its contribution to greenhouse gas emission is estimated at around $5 \%$ (Gössling, 2002), and this share is increasing. In addition to these global problems, tourism causes increasing pressure on social, ecological and economic systems around the world as a result of its concentration in space and time. In most destinations, there are marked peak seasons, which cause sub-optimal use of facilities and put ecological and societal carrying capacities to the test. Seasonality is known to have important climatological and institutional components, but the mechanisms behind the phenomenon are as yet poorly understood.

The lion's share of tourism is concentrated in limited numbers of destinations, most of them in coastal and mountainous areas. The development of these destinations often started as a historical accident, and continued as a result of positive feedback effects, resulting from imitation and economies of scale. A third dimension of concentration was found to be social concentration. A case study, performed in Kenya, revealed that the distribution of revenues over the local population is strongly linked to staging activities by the tourist industry. Staging not only allows tourists to use their holiday time efficiently; it also allows the stagers (usually large tourism businesses) to keep out competition from local entrepreneurs. Since the local people are aware of the fact that they are part of the exotic scenery that is being sold, there is widespread dissatisfaction with the outcome of tourism.

In spite of the great importance of tourism, studies integrating its many spatial, temporal and disciplinary dimensions are few in number. A large part of the literature is based on individual case studies that are often difficult to compare.

\subsubsection{SCENARIOS FOR FUTURE TOURISM}

The number of structured explorations of the future of tourism is rather limited. Assessments of trends are available, as well as forecasts, but these provide no 
integral and coherent outlooks, and do not address uncertainties in a satisfactory way. In this thesis, the future of tourism was explored using integrated scenario analysis. The SRES suite of scenarios, produced by the Intergovernmental Panel on Climate Change (IPCC) was found to be a useful starting point for these explorations. The four SRES scenarios differ along two dimensions: the world's geographical orientation (globalisation or regional division) and its ethical orientation (economy-driven or sustainability-driven). These four scenarios paint very different pictures in terms of tourism growth rates (and scale) and distribution patterns. The two scenarios in which tourism is dominated by considerations of price and cost depict worlds in which tourism is concentrated in large resorts, and in which alternative forms of tourism are pushed back into small miche markets. In contrast, the two scenarios that are dominated by quality considerations leave much more room for these alternative forms of small-scale, low-impact tourism. The two scenarios that assume ongoing globalisation and worldwide unification produce worlds in which tourism is democratised all over the world, and in which the market segment of long haul trips continues to grow. In contrast, the two scenarios that postulate the formation and development of competitive or even hostile world regions project much more diverse patterns of tourism development and much less room for growth of the long haul market.

In all scenarios tourism continues to grow, albeit at different speeds. Problems related to the overall volume of tourism will therefore continue to exist in all scenarios considered. Pressure patterns were found to vary markedly between the scenarios. The high levels of spatial concentration of tourism in the pricedriven scenarios may be difficult to support by local ecological and social systems, but its impact may be managed more efficiently because of potentially large economies of scale, leading to relatively modest problems on an aggregated level. The spatial distribution of tourism over large areas in the quality-driven scenarios may lead to relatively modest problems on the local level, but since the problems are spread out across larger areas, the overall negative impacts on biodiversity and communities are relatively large. At the same time, however, small-scale, low-growth, locally controlled tourism development provides better conditions for a socially equitable distribution of tourism revenues.

It was concluded that to reach even locally sustainable forms of tourism, many destinations would require a structural transformation. Such a transformation is a long-term process, requiring actions by many stakeholders, with an end state that is fuzzy, as a result of the ambiguity of the meaning of 'sustainable tourism'. The new paradigm of transition management, which has been developed to help guide structural societal transformations, was applied to sustainable 
tourism by sketching the outlines of a hypothetical transition management process.

The scenario approach takem in this thesis is based on the SRES suite of scenarios. Whereas these scenarios have proved to be a useful starting point for exploring the future, they have a number of drawbacks and peculiarities. First of all, all four scenarios postulate continued economic growth in all or most regions of the world. In light of the physical limits to growth (e.g. resources, sink functions, space), that some perceive to be imminent, this approach is at least incomplete. The scope of the scenario analysis could be considerably broader by taking aboard scenarios of stagnation or global redistribution. In the second place, the SRES scenarios have been used in many studies, but they were originally developed for the exploration of future emission levels, not future tourism. As a result of the focus on emissions, the scenarios put more emphasis on scale than on distribution, which is an important drawback from the perspective of tourism studies.

Transition management was found to be a potentially useful tool to guide transitions of destinations towards more sustainable tourism development, but the concept has not yet been tested in practice. Experiments with transition management in other sectors, such as energy and mobility, have been promising, but application to tourism, following the process outlined in this thesis, is needed to assess its added value. A fundamental issue that emerged from this thesis is the question whether a transition towards sustainable tourism development on a global level is feasible. Such a transition would probably not only require changes in economic incentives, institutions, attitude etc., but also in the overall scale of tourism. It is difficult to imagine how the global level of tourist activity could be capped without affecting people's freedom to travel. The tourist industry essentially belongs to the service sector: tourist experiences are produced and consumed at the same time. Travelling to other places is an essential part of the tourist experience, and there is a limit to the possibilities of reducing the impact of the physical movement of people around the globe: they necessarily use energy, space, water and other resources, and they cause congestion. Trying to reconcile the individual right to travel with local, regional and global economic, ecological and social carrying capacities will be the main challenge of tourism in the coming decades.

\subsubsection{CLIMATE CHANGE AND TOURISM}

Climate and weather are major components determinants of current tourist flows. Around a hundred million northern-European tourists travel to the Mediterranean region every year (Mather et al., 2005), and similar patterns exist in other parts of the world. Climate change can thus have significant impacts on tourism. These impacts may have many different faces, ranging from direct 
impacts on tourist comfort, to indirect impacts through changes in nature and landscape. This thesis explored the impacts of climate change on the climatic attractiveness of tourist destinations throughout the world, as well as the general impacts of climate change on tourist activities in the Netherlands and on Dutch holidaymaking abroad.

For the global explorations, the SRES emission scenarios were integrated with the HadCM3 general circulation model to obtain grid-based projections for a range of meteorological variables. These projections were used to calculate climate suitability indices for all 0.5 by 0.5 degree land cells. The climate suitability indices that were used were the Tourism Climatic Index, developed by Mieczkowski (1985), and the Hatch index (1988). To test their performance, these indices were calculated for the period of 1961-1990 using measured data. This test was encouraging. It illustrated that the most comfortable areas for general tourism activity during the northern summer months include the countries of the northern Mediterranean coast from Spain to Turkey, the western portion of the United States, the central portion of southern Africa, and northern Australia. This closely matches actual tourism patterns.

Index values were subsequently calculated for future periods. While the results differed significantly between scenarios and the two indices, they all pointed in the same direction. On an aggregated level, there is only a slight decrease in average annual index values, which may be the reason why analyses based on annual temperatures found little impact of climate change on overall tourist volumes (e.g. Hamilton et al., 2005). The aggregated change is, however, very small compared to the geographical and seasonal shifts. Climatic suitability for tourism decreases unequivocally in the tropics, with scores decreasing virtually year-round. Close to the poles, climatic suitability for tourism increases almost unequivocally, with suitability scores increasing year-round. In the northern hemisphere these areas stretch as far south as Canada, the UK, the Netherlands and the Baltic states. In the southern hemisphere, there is much less unequivocal improvement because the landmasses are much smalier there. An important observation is that the unequivocal nature of the improvements is probably temporary as it depends on the time horizon chosen. As climate change progresses, the zones of good conditions will continue to shift towards the poles, until eventually the whole world is confronted with either unequivocal deterioration of conditions, or with mixed results for different seasons.

Up until 2100 , climate change will have mixed results for the suitability scores of a number of the world's leading tourist destinations. Special attention was paid to the world's leading destination: the Mediterranean. The northern Mediterranean will see its summer scores plummet, while conditions improve 
signiffcantly in spring and autumn. Conditions in the main source countries of northern Europe, on the other hand, improve considerably throughout the year, with the summer season becoming particularly attractive. It was concluded that the ultimate impact of climate change on destinations that face mixed results is highly dependent on institutional developments. If institutional holiday arrangements stay as they are, school hollidays will continue to dictate holiday schedules. As summer conditions in the Mediterranean deteriorate, tourists will have little other option than to choose another holiday destination, perhaps closer to home. This would be disastrous for the tourist industry in the Mediterranean countries. If, on the other hand, institutional arrangements turn out to be flexible, they have the additional option of going on holiday in another season rather than in another holiday destination. In this scenario, climate change could be beneficial for the Mediterranean, as visitation would be more equally divided over the year, resulting in a more efficient use of tourist facilities.

The analyses in this thesis have produced insightful results, but they leave a lot to be desired. In the first place, the scenarios and climate models used postulate gradual climate change and do not consider abrupt climate change. If run-away climate change were to occur, if the thermohaline circulation were to reverse, or if a large Antarctic ice shelf were to collapse and melt, fundamentally different scenarios would develop. These were not discussed in this thesis. In the second place, of the many general circulation models that are available, only one was used. Although the HadCM3 model is one of the most frequently used models, the robustness of the results would benefit from taking a few other models into consideration. In the third place, while the suitability indices that were used seem to replicate the actual visitation patterns quite well, empirical validation has been limited. A major reason for this is the lack of visitation data with sufficient spatial and temporal detail. The tourism statistics that are published by the World Tourism Organisations and other institutes are typically annual, country-by-country data. These statistics are valuable for macroeconomic analysis, but ill suited to support studies of the links between tourism and global (environmental) change. The lack of suitable data on tourism also hampers the analysis of the relative importance of climate change compared to that of other factors, such as economic development and population growth.

Climate change was found to have predominantly beneficial results for recreation and tourism in the Netherlands. In all scenarios conditions improve throughout the year, resulting in a longer holiday season. This would allow a more efficient use of facilities and produce a more profitable tourist industry. The stimulating effect of climate change on beach tourism was found to be partly offset by the risk of coastal erosion, resulting from sea level rise. As long as sea level rises not too quickly, however, these effects can probably be mitigated by sand suppletion. Climate change was projected to have a negative 
impact on skating opportunities in the Netherlands, as the number of frost days is expected to diminish. In addition, Dutch winter sports enthusiasts may have to find other winter holiday destinations, as more and more ski resorts in the Alps are left without snow.

The involvement of stakeholders in the analyses for the Netherlands added knowledge, expertise and perspectives to the exploration, leading to more balanced results. This could, however, not entirely make up for the fact that there was little scientific information available to base the analysis on. To date, little scientific knowledge is available about the relationship between weather and climate conditions on the one hand and the behaviour of tourists, recreationists, and tourist entrepreneurs on the other. With essential information about the current links missing, projections of the future effects of climate change are difficult to make. While providing some initial insights into the possible effects of climate change on tourism and recreation in the Netherlands, the analyses should therefore first and foremost be interpreted as agendasetting activities, pointing to missing information and issues for future research.

\subsubsection{AVIATION TAXES}

Tourism is closely linked to aviation. With an estimated $50 \%$ of flights made for leisure purposes, the aviation industry would not be the same without tourism. At the same time, tourism would not be the same without aviation, as air travel has greatly expanded the geographical reach of tourists. Part of the success of aviation is attributable to fiscal policy. At the end of the Second World War many countries agreed to exempt aviation from paying taxes to stimulate international travel and foster international peace and friendship. Seen from a historical perspective, this decision is understandable, but the rationale seems to have lost its strength now that aviation has developed into an enormous industry with many detrimental effects on nature and society. For the moment, the tax exemptions are firmly embedded in hundreds of bilateral treaties that are difficult to change. The integration of Europe offers possibilities for change, however, as the European Union is not bound by the key international treaties on aviation.

A future reduction or abolition of the fiscal advantages of the aviation industry could well cause a discontinuity in tourism development. The analyses in this chapter show that the introduction of VAT on tickets, and the introduction of levies on kerosene use would substantially increase ticket prices. In particular chartered flights and long-distance flights would become much more expensive. If jet fuel and tickets had been taxed according to the lowest levels in the EU in 2002 , this would have yielded an estimated 11.5 billion euros in tax revenues in the EU-15 alone; it would have reduced demand by an estimated $30 \%$ for domestic and short-haul flights, and $50 \%$ for long-haul and chartered flights. 
The contribution to climate change, expressed in terms of $\mathrm{CO} 2$ equivalents, would have been an estimated 124 Mton lower, which is comparable to the total emission by Greece in that same year of 2002 .

Of course price increases and demand responses greatly depend on the size of the levies and taxes introduced, and on the demand elasticities used. This thesis explored the impact of levies that are modest from a European car owner perspective, but probably much too high to be politically feasible Rather than developing plausible scenarios of what might happen, this thesis aimed at giving a rough estimate of the current fiscal advantages of the aviation industry and the relevance of these aidvantages for air travel demand. To this end, actual demand levels were compared with hypothetical levells that would have existed in the absence of tax exemptions. One of the main criticisms that could be levelled against the approach is that demand ellasticities can only be used for marginal changes price. The price changes that are considered may be too large for static elasticities to be justified. In follow-up studies that would seek more precise answers, the use of a computer model that allows for the analysis of feedback mechanisms, would be advisable.

\subsection{Future research}

This thesis demenstrates the importance of scale and distribution in tourism; it also reveals the dearth of studies addressing these issues and their implications from a global perspective. Numerous local case studies have been performed, but the number of studies integrating their results is very limited. Structured explorations of the future of tourism are also scarce, despite the fact that many worry about the potential implications of ongoing tourism growth, with huge new markets in India, China and elsewhere yet to be developed.

A promising area of future research is the analysis of spatial and temporal tourism patterns by means of geographical information systems (GIS). Current (econometric) demand models typically ignore the spatial dimensions, by taking entire countries as basic units of analysis. They also ignore seasonality by using annual averages. GIS-based research of tourist flows could produce new insights into the determinants of tourist flows around the world. Putting a range of push and pull factors of tourism demand together in a spatially and temporally explicit database would allow an assessment of the relative importance of each of these factors in explaining tourist flows. In addition it would allow a high-level assessment of the patterns of ecological and social pressure that tourism causes. Although time-consuming, collecting sufficient amounts of data seems feasible. Grid-based datasets with acceptable resolutions are available for population, land use, nature and other important 
determinants. Other data would have to be collected at regional or local levels and aggregated. Once established, a GIS-framework would also allow a more integrated assessment of the implications of climate change for tourism, and of its relative importance compared to other tourism determinants. These ideas will be tested and further developed in the context of a research project about the economic costs and benefits of climate change for a range of sectors in Europe, which is financed by the Joint Research Centre. Within this PESETA project, ICIS will be responsible for assessing the impact on tourism.

Another promising research field is the study of tourism vulnerability. Rather than reasoning top-down from the driving forces to the impacts and the individual tourist actors, vulnerability analysis takes the position of individual actors or regions as its starting point. Their sensitivity to change and ability to adapt are analysed, which is something that these actors and regions can easily identify with. It has clear relevance for their everyday life, is relatively independent from the actual level of change, and does in principle not require the use of abstract and uncertain scenarios that many stakeholders have little faith in. At ICIS, vulnerability analysis is currently being applied to answer the question how vulnerable tourist businesses and resorts in Europe's coastal zones are to climate change.

\section{References}

Gössling, S. (2002). "Global Environmental Consequences of Tourism." Global Environmental Change, 12(4): 283-302.

Hamilton, J. M., Maddison, D. and Tol, R. S. J. (2005). "Climate Change and International Tourism: A Simulation Study." Glohal Environmental Change, 15(3): 253-266.

Hatch, D. (1988). "The Distribution of World Climate Conditions." Joumal of Metearology, 13(133s): $344-349$.

Mather, S., Viner, D. and Todd, G. (2005). "Climate and Policy Changes: Their Implications for International Tourism Flows." in: Hall, M. and Higham, J. (eds.) Tourism, Racreation and Cfimate Change, Channel View Publications: Clevedon, UK, 63-85.

Mieczkowski, Z. (1985). "The Tourism Climatic Index: A Method of Evaluating World Climates for Tourism." The Canadian Geographer, 29(3): 220-233.

UNWTO (2006). "World Tourism Barometer, Volume 4, No. 1. January 2006:" World Tourism Organisation: Madrid. 
Samenvatting 


\section{Samenvatting}

Op vakantie gaan is voor velen een populaire vrijetijdsbesteding. Het stelt mensen in staat weer helemaal tot rust te komen, de dagelijkse beslommeringen van zich af te zetten, een beetje bij te bruinen en wat van de wereld te zien. Onder invloed van economische, demografische, technologische en culturele ontwikkelingen heeft het toerisme internationaal een enorme vlucht genomen, met name sinds de Tweede Wereldoorlog. Naar verluidt zorgt het toerisme voor ongeveer $10 \%$ van het wereldinkomen en heeft een op de twaalf werknemers een baan in deze sector. Kleine eilandstaten met weinig grondstoffen en ontwikkelingsmogelijkheden hebben in toerisme een basis gevonden voor economische groei, en menig natuurgebied wordt dankzij het toerisme beschermd en in stand gehouden.

Toch is er reden tot zorg. Die zorg heeft niet alleen met het hedonistische karakter van het toerisme te maken, maar vooral ook met zijn omvang en groei, en met de verdeling van voor- en nadelen over ruimte, tijd en mensen. Nu al is het toerisme verantwoordelijk voor ongeveer $5 \%$ van de uitstoot van broeikasgassen en dit percentage stijgt snel, met name door het toenemend gebruik van het vliegtuig. Toeristische activiteiten zijn ook sterk seizoensgebonden, wat niet alleen onvoordelig is voor de toeristische industrie maar ook geconcentreerde druk oplevert voor natuur en maatschappij. Bovendien is een groot deel van het toerisme samengebald in een relatief klein aantal zones, vooral in kuststreken en berggebieden. De huidige trends wijzen op onverminderde groei van het toerisme in de toekomst, maar kunnen de trends van toen en nu wel zonder meer naar de toekomst worden doorgetrokken?

In dit proefschrift wordt een aantal mogelijke toekomsten van het toerisme verkend, alsmede de gevolgen daarvan. Speciale aandacht is er daarbij voor potentiële trendbreuken, waarvan de eerste tekenen zich nu al manifesteren. De eerste is klimaatverandering, een ontwikkeling die de richting en omvang van toeristenstromen in de hele wereld drastisch kan veranderen. Een tweede mogelijke discontinuitteit is het afschaffen of verminderen van de fiscale voordelen van de internationale luchtvaart, die thans is vrijgesteld van het betalen van accijnzen op kerosine en van BTW-heffing op tickets.

Hoofdstuk 1 plaatst de toeristische ontwikkelingen van de afgelopen decennia in het licht van een aantal grote trends die tezamen kunnen worden aangeduid als mondialisering. Toerisme wordt daarbij uitdrukkelijk niet alleen gezien als gevolg van de toenemende internationale vervlechting van allerlei processen, maar ook als een van de veroorzakers daarvan. Geconcludeerd wordt dat toerisme onlosmakelijk verbonden is met mondialisering. De wederzijdse 
afhankelijkheid tussen toerisme en een veelheid aan mondialle, regionale en lokale ontwikkelingen maken van toerisme een ongrijpbaar geheel. De gangbare reductionistische en controlistische benaderingen van het toerisme in wetenschap en beleid sluiten slecht aan bij deze realiteit. Vandaar dat in dit proefschrift gebruik wordt gemaakt van methoden die voortkomen uit de complexiteitstheorie en de Integrated Assessment wereld.

Hoofdstuk 2 geeft een overzicht van de methodologische gereedschapskist waarvan in dit proefschrift gebruik wordt gemaakt. Geconcludeerd wordt dat complexe problemen, zoals het toerisme, niet op een toereikende manier kunnen worden geanalyseerd met monodisciplinaire en reductionistische methoden. De aanwezigheid van fundamentele onzekerheden en cruciale terugkoppelingen naar processen buiten het monodisciplinair bestudeerde systeem zijn daarbij belangrijke argumenten. Onvrede met de tekortschietende instrumenten: uit de afzonderlijke disciplines speelde een grote rol bij de ontwikkeling van Integrated Assessment (IA). In een notendop wordt het instrumentarium van IA besproken, dat bestaat uit onder meer modelanalyse, scenarioanalyse, risico-en onzekerheidsanalyse en participatieve methoden. De toekomst van het toerisme en de omvang en verspreiding daarvan wordt in het proefschrift verkend met behulp van geïntegreerde scenario's, met ondersteunende rollen voor modelanalyse en participatieve methoden.

Hoofdstuk 3 gaat in op de factoren die de groei van het toerisme hebben bepaald, alsmede op de effecten van het toerisme. De drijvende krachten achter het toerisme worden verdeeld in factoren die invloed hebben op de toerist zelf (zoals het gezinsinkomen of de wens tot zelfontplooiing), op diens omgeving (zoals modeverschijnselen of de mate van verstedelijking), en op het algehele maatschappelijke kader (zoals bevolkingsgroei of individualisering). De effecten worden onderverdeeld in effecten op de economie (bijvoorbeeld inkomen of werk), het milieu (bijvoorbeeld emissies of bescherming van natuurparken), de sociale verhoudingen (bijvoorbeeld migratie of vrouwenemancipatie), en de cultuur (bijvoorbeeld commercialisering of revival van oude gebruiken). Tot slot besteedt het hoofdstuk aandacht aan de oorzaken achter de concentratie van toeristische activiteiten in ruimte en tijd, en achter de ongelijke verdeling van de voor- en nadelen van het toerisme over gemeenschappen.

Hoofdstuk 4 bespreekt een casestudy die de verdeling van de opbrengsten en kosten van cultuurtoerisme in de Keniaanse stad Mombassa onder de loep neemt. Die verdeling blijkt gekoppeld te zijn aan het fenomeen van 'staging', oftewel het in scène zetten van culturele uitingen ten behoeve van het toerisme. Behalve gevolgen voor de authenticiteit van de toeristische ervaring blijkt staging ook economische implicaties te hebben. Staging is namelijk niet alleen 
een middel om de toerist het maximale uit zijn vakantie te laten halen, maar ook om concurrenten buiten de deur te houden. Toeristische ondernemers creëren overzichtelijke toerisme-enclaves en proberen die op allerlei manieren af te schermen van de buitenwereld om zo een maximaal deel van de inkomsten voor zichzelf te behouden. De lokale bevolking in Mombassa wordt wel geacht het exotisch decor te vormen van deze voorstelling, maar krijgt niet of nauwelijks toegang tot de toeristen, met minimale verdiensten uit het toerisme tot gevolg. De frustratie die dit veroorzaakt uit zich onder meer in het hinderlijk aanspreken en aanklampen van toeristen, die daarvan vaak niet gediend zijn. Ongeorganiseerde vormen van toerisme kunnen wellicht voor verbetering van de situatie zorgen omdat die minder gebonden zijn aan toeristische enclaves.

In hoofdstuk 5 wordt een viertal toekomsten van het toerisme verkend. Deze toekomsten borduren voort op een door de Intergouvernementele Werkgroep inzake Klimaatverandering (IPCC) ontwikkelde set scenario's. Die scenario's onderscheiden zich op basis van twee dichotomieën: verdergaande mondialisering versus regionale blokvorming, en markt versus duurzaamheid als maatschappelijk uitgangspunt. De vier scenario's hebben uiteenlopende toekomsten voor het toerisme in petto. In de mondialiserende, marktgerichte wereld komt het toerisme sterk op in de ontwikkelingslanden van $\mathrm{nu}_{\text {, en }}$ concentreert het toerisme zich in massale resorts om te profiteren van schaalvoordelen. In de regionaliserende, marktgerichte wereld stagneert de groei van het toerisme, wordt er weinig geïnvesteerd en zijn verre vakanties zeldzaam. In de mondialiserende, verduurzamende wereld neemt het toerisme sterk toe, zich verspreidend over vele kleine bestemmingen om tegemoet te komen aan individuele eisen en om te zorgen voor een betere lokale inbedding. In de regionaliserende, verduurzamende wereld verschilt de groei van het toerisme sterk per regio, maar ook hier zet de trend naar lokale kleinschaligheid door. De overgang naar een duurzamer georganiseerd toerisme is geen vanzelfsprekendheid, maar een langdurig proces van al doende leren en al lerende doen, waarbij verschillende partijen betrokken zijn. Transitiemanagement is een veelbelovend instrument om zulke processen te begeleiden.

Hoofdstuk 6 verkent de mogelijke effecten op het toerisme van een relatief nieuw verschijnsel: klimaatverandering. Het klimaat is belangrijk voor het toerisme: honderden miljoenen mensen gaan jaarlijks op vakantie naar de zon. Veranderingen in de klimatologische omstandigheden thuis en op de vakantiebestemming kunnen dus zorgen voor verschuivingen in toeristenstromen. Dit hoofdstuk verkent via modelberekeningen aan de hand van vier IPCC scenario's de veranderingen in klimatologische geschiktheid van toeristische bestemmingen, waarbij die geschiktheid wordt uitgedrukt in speciale indices. Hoewel de resultaten per scenario en index verschillen is de 
trend duidelijk. Gebieden rond de evenaar worden het hele jaar minder aantrekkelijk, terwijl de omstandigheden in gebieden dichterbij de polen juist verbeteren. Nieuw-Zeeland, Canada, Engeland en Nederland zijn gebieden met gunstige vooruitzichten: deze eeuw worden de zomers beter en het vakantieseizoen langer. Voor de overige gebieden zijn de resultaten gemengd. Het Middellandse Zeegebied krijgt bijvoorbeeld te maken met een aanzienlijke verslechtering in de zomer; terwijl de omstandigheden in het voor- en najaar juist flink verbeteren. Of dit voor Zuid-Europa positief of negatief zal uitpakken, hangt sterk af van de flexibiliteit van de vakantieganger bij het uitkiezen van zijn vakantieperiode.

Hoofdstuk 7 gaat dieper in op de mogelijke gevolgen van klimaatverandering voor Nederland. Het aantal mooie dagen in Nederland neemt toe en ook wordt het seizoen langer. Verwacht wordt daarom dat de buitenreactie langs de hele linie zal toenemen. Aangezien het klimaat wisselvallig zal blijven, valt niet te verwachten dat Nederland vanwege zijn klimaat een veel populairdere vakantiebestemming voor buitenlandse toeristen zal worden. De zeespiegelstijging kan voor problemen zorgen langs de kust vanwege strandafslag en eventuele schade aan toeristische infrastructuur. Zandsuppletie kan hierin verlichting brengen. Het moderne waterbeleid, dat water steeds meer ruimte biedt om de toenemende waterafvoeren te kunnen verwerken, kan voor nieuwe kansen zorgen voor de watersport. Elfstedentochten blijven mogelijk, maar worden wel steeds zeldzamer, en om te skiën moeten Nederlandse wintersporters wellicht de Alpen gaan verruilen voor andere gebieden, vanwege de verslechterende sneeuwzekerheid.

Hoofdstuk 8 bestudeert de achtergronden van de belastingvrijstellingen die de luchtvaart geniet. Deze vrijstellingen zijn historisch goed verklaarbaar. Na de Tweede Wereldoorlog wilde men internationale contacten stimuleren ter bevordering van de wereldvrede. Inmiddels is de luchtvaart uitgegroeid tot een enorme sector, mede dankzij het toerisme dat wereldwijd ongeveer $50 \%$ van de vluchten voor zijn rekening neemt. Via geluidsoverlast en emissies van broeikasgassen levert de luchtvaart een belangrijke bijdrage aan hedendaagse maatschappelijke problemen. De belastingvoordelen staan daarom onder druk, al zitten ze voorlopig nog stevig verankerd in internationale verdragen. De Europese Unie, die niet gebonden is aan deze verdragen, kan wellicht een doorbraak forceren. Dit hoofdstuk verkent de gevolgen van normalisering van de fiscale positie van de luchtvaart. Als de Europese luchtvaart in 2003 het Griekse benzineaccijnstarief op kerosine had moeten betalen, en het Luxemburgse BTW-tarief had moeten gebruiken voor tickets (de laagste tarieven van de EU-15), zou het aantal reizigers enkele tientallen procenten lager zijn uitgevallen. Met name langeafstandsvluchten en chartervluchten blijken gevoelig voor belastingheffing. Afschaffing of reductie van de bijzonder 
effectief gebleken belastingvoordelen zou een trendbreuk kunnen veroorzaken in de omvang van het internationale toerisme. Juist deze grote gevolgen maken een beleidswijziging echter ook zeer lastig.

Hoofdstuk 9 vat de belangrijkste conclusies van het uitgevoerde onderzoek samen en plaatst deze in het perspectief van de onderzoeksvragen uit de inleiding. Onder invloed van een hele reeks factoren heeft het toerisme zich de afgelopen decennia zeer sterk ontwikkeld. Toerisme heeft veel aantrekkelijke kanten, maar zorgt ook voor een aantal grote problemen, die vaak te maken hebben met schaal en concentratie. Alom wordt aangenomen dat toerisme verder zal groeien, maar de manier waarop en de sneiheid waarmee staan niet vast vanwege het grote aantal onzekere invloeden. Met scenario's is op coherente wijze een aantal mogelijkheden verkend, die sterk van elkaar verschilden voor wat betreft de groei in ontwikkelingslanden en de spreiding van het toerisme in ruimte en tijd. Klimaatverandering dient zich aan als belangrijke invloed op toerismepatronen in de wereld. Het belangrijkste toerismegebied ter wereld, het Middellandse-Zeegebied krijgt te maken met verslechterende omstandigheden in de zomer, maar betere condities in de lente en herfst. Of de vakantiegangers de zomer zullen verruilen voor een ander seizoen en het gebied zullen blijen bezoeken of hun zomervakantie elders zullen doorbrengen, hangt sterk af van institutionele ontwikkelingen. Toerisme en recreatie in Nederland zullen profiteren van klimaatverandering, al is het kustgebied kwetsbaar vanwege zeespiegelstijging. De grote belastingvoordelen die de luchtvaart geniet staan onder druk door de grote negatieve effecten op welzijn, gezondheid en milieu. Invoering van een kerosineheffing en van BTW op tickets zou de prijzen in de luchtvaart sterk laten stijgen en tot een trendbreuk in het toerisme kunnen leiden. Gestructureerd onderzoek naar de toekomst van het toerisme staat nog in de kinderschoenen, maar is een zeer interessant onderzoeksgebied. GIS-technieken bieden veelbelovende mogelijkheden om de ruimtelijke en temporele effecten van toeristische ontwikkeling beter te bestuderen. 



\section{Dankwoord \&}

\section{Acknowledgements}





\section{Dankwoord \& Acknowledgements}

Dit proefschrift is de bekroning van jaren van onderzoek op het gebied van toerisme, duurzame ontwikkeling, en integrated assessment. This research was supported by the Center for Integrated Study of the Human Dimensions of Global Change, through a cooperative agreement between the National Science Foundation (SBR-9521914) and Carnegie Mellon University.

Promotietrajecten gaan doorgaans gepaard met vele ups en downs, en het mijne was daarop zeker geen uitzondering. Boven alles is een promotie een worsteling met jezelf, waarbij niet alleen je talenten maar vooral ook je zwakheden onherroepelijk komen bovendrijven. Over je eigen beperkingen en andere grote hindernissen kun je alleen heenkomen met de steun en inspiratie van anderen. Die anderen wil ik hier graag bedanken.

Allereerst mijn beide promotoren: prof. Jan Rotmans en prof. Pim Martens. Jan, jouw gedrevenheid, scheppingskracht en je intellectuele brille zijn voor mij altijd een grote bron van inspiratie en een lichtend voorbeeld geweest. Ook heb ik mij vanaf het allereerste begin sterk kunnen identificeren met de geest van het ICIS, dat jij samen met Marjolein van Asselt hebt opgebouwd. Jouw manier van kijken naar de wereld is van groot belang geweest voor mijn intellectuele ontwikkeling, en ik ben je daarvoor veel dank verschuldigd. Ook kijk ik met plezier terug op onze squashwedstrijdjes, al kon ik niet altijd (of beter gezegd: slechts een enkele keer) van je winnen.

Pim, aan jou heb ik veel steun gehad in de latere fase van mijn promotieonderzoek. Sinds jij bent aangetreden als directeur is het wereldbeeld van ICIS een klein beetje veranderd, wat onder andere tot uiting komt in een iets andere naam. Wat echter vooral is veranderd, is de managementstijl. Onder jouw leiding ontwikkelt ICIS zich verder van pionierend instituut naar een volwassen onderzoeksgroep. Voor de ontspannen en opgeruimde manier waarop je dat doet heb ik veel bewondering. Verder ben ik je dankbaar voor de ruimte die je me biedt om het toerismeonderzoek bij het ICIS uit te breiden. I $\mathrm{k}$ kijk erg uit naar verdere samenwerking in de komende periode.

I owe a special word of thanks to dr. David Viner of the Climatic Research Unit (CRU) in Norwich. David: we have already had a lot of fun in lots of meetings and in lots of pubs, and $I$ am sure there is more to come. Thanks for the great hospitality I received from you and Imogen. In a professional sense, you have helped me direct my research towards the emerging field of climate change and tourism. We have been working together on the expansion of the eCLAT research network, and we have organised a number of workshops together. Cheers, Dave! 
Door de jaren heen heb ik bij ICIS heel wat collega's meegemaakt. Mensen met zeer uiteenlopende karakters en stijlen, maar vrijwel zonder uitzondering zeer collegiaal en welwillend. Na een roerige periode heeft zich bij ICIS de laatste tijd een stabiele en hechte groep van collega's ontwikkeld, waarmee het prettig samenwerken is: Alvaro, Annet, Annemarie, Anja, Jan, Machiel, Marc, Maud, Mita, Pieter, Pim, René, Zdenka: hartelijk dank en thanks a lot! In het bijzonder ben ik grote dank verschuldigd aan Machiel Lamers omdat hij met zijn stageonderzoek in Kenia de basis legde voor hoofdstuk 4 in mijn proefschrift. Bedankt daarvoor!

Van mijn oud-collega"s wil ik allereerst Daniël Meijers bedanken voor zijn onderzoek naar de historische achtergronden van de belastingvrijstellingen voor de luchtvaart. Dit werk vormt een belangrijke basis en inspiratiebron voor hoofdstuk 8 in mijn proefschrift. In een eerdere fase heeft ook Pieter-Jelle Beers een bijdrage geleverd aan het promotieonderzoek. Het voert te ver om hier ook alle andere oud-collega's individueel te noemen en te bedanken, en bovendien zou dat onherroepelijk tot vervelende omissies leiden. Daarom een collectief: dank jullie wel!

Mijn paranimfen wil ik graag bedanken voor hun vriendschap en steun. In de eerste plaats Sandra, die samen met mij op 1 februari 1999 bij het ICIS kwam werken. Sandra, vanaf die dag ontwikkelde zich tussen ons een theel speciale vriendschap. Zelden ben ik iemand tegengekomen met wie ik het zo goed kon vinden als met jou. Het voelt een beetje raar om je daarvoor te bedanken, maar ons contact is en blijft voor mij uniek. Jaarlijks pekskes aan en hossen met carnaval, op pad in de zelfstartende ICIS-mobiel, en zonder water stranden in de snikhete Spaanse bergen. Zonder jou waren de eerste jaren in Maastricht een stuk minder aangenaam geweest. De grote pret die we samen met Maurice hadden binnen de social-events commissie mag daarbij ook niet onvermeld blijven.

Mijn tweede paranimf is Arco: studiegenoot, dispuutsgenoot, partijgenoot, en bovenal een heel goede vriend met een grote gave om ingewikkelde situaties direct te doorgronden en bijpassende oplossingen aan te dragen. Arco, veel dank voor je vriendschap en goede raad en voor de mooie momenten in onder meer de Arena en Zwitserland-aan-Zee.

Verder wil ik graag mijn studievrienden van de Vrije Universiteit bedanken. Maud, Gerda, Martijn, Sef, en Ron, en inmiddels ook Jeroen, Christian en Susanne: dat we na al die jaren nog steeds contact houden door regelmatig bij elkaar te gaan eten, kan ik bijzonder waarderen. Het is elke keer weer heel vertrouwd en gezellig. 
En dan mijn squashvrienden: Henk-Jan, Marc, Kasper en Eise, bedankt voor de vele uurtjes speelplezier. Met Kasper speelde ik wekelijks een uurtje squash, dat vaak werd gevolgd door een langduriger bezoek aan stamkroeg de Witte Ballons, waar wij als fris gedouchte jongens met sporttas vaak wat waterig werden aangekeken door de blowende stamgasten.

Wie zeker niet mag ontbreken in dit dankwoord is mijn partner-in-crime in havenzaken, Nel Dombrowski-Gaal. Nel, aan jou zijn in de acht jaar dat ik je ken zeker de helft van mijn belminuten opgegaan. Wekelijks, en soms zelfs dagelijks hebben we contact over de laatste ontwikkelingen in het Noordzeekanaalgebied. De megalomanie van de havenplannen is voor ons beiden een bron van ergernis, maar wat hebben we ook een plezier beleefd aan ons verzet! Jouw enthousiasme en de lol die we samen hebben, hebben mij door de nodige moeilijke periodes heen gesleept.

Sinds ik naar Maastricht ben vertrokken, kom ik niet zo vaak meer over de vloer bij mijn ouders in Baarn en broer in Amsterdam. Ik weet dat zij dat net als ik ervaren als een groot offer. Ondanks de afstand heb ik mij altijd zeer gesteund gevoeld door hun rotsvaste vertrouwen. Aan mijn ouders draag ik dan ook mijn proefschrift op.

Laatst en liefst: Anouk. Inmiddels kennen we elkaar nu alweer bijna twee jaar en wonen we anderhalf jaar samen. De afgelopen periode is door de promotie druk en hectisch geweest; gelukkig heb je daar met veel begrip op ingespeeld. Binnenkort verhuizen we naar Vlijtingen in België en begin jij aan een nieuwe baan. Hopelijk breekt er dan een wat rustigere periode aan. We gaan er iets moois van maken! 
$\because=\quad \because \quad+\cdots$

$8 \quad \therefore$

s.

$\therefore$ 
Curriculum vitae 



\section{Curriculum vitae van Sebastiaan Bartholomeus Amelung}

Op 18 november 1971 werd ik geboren in Utrecht. Getogen ben ik echter in Baarn, waar ik de Nieuwe Baarnse School doorliep en later doorstroomde naar het Baarnsch Lyceum. Toen ik in de zomer van 1990 het eindexamen vwo achter de rug had, vertrok ik naar Granada in Spanje om daar een jaar Spaans te studeren. In 1991 begon ik met een studie economie aan de Vrije Universiteit van Amsterdam (VU) en in 1992 met een studie Spaans aan de Universiteit van Amsterdam (UvA). In 1994 haalde ik het propedeutisch examen Spaans en in 1997 studeerde ik als algemeen milieu-econoom af met een scriptie over de relatie tussen toerisme en de ontwikkeling van natuurparken in Costa Rica. Al solliciterende stortte ik mij vervolgens bij Milieucentrum Amsterdam een jaar lang op de voors en vooral tegens van een nieuwe zeesluis bij IJmuiden en van de uitbreidingsplannen van de Amsterdamse haven. Begin 1999 begon ik als promovendus bij het International Centre for Integrative Studies (ICIS) aan een onderzoek naar toerisme, resulterend in dit proefschrift. Inmiddels onderzoek ik als postdoc bij ICIS de mogelijkheden voor duurzaam toerisme op het Antarctisch Schiereiland.

\section{Curriculum vitae for Sebastiaan Bartholomeus Amelung}

On 18 November 1971, I was born in Utrecht, but I spent my childhood in Baarn, where I also went to school. After completing secondary education at the Baarnsch Lyceum, I spent one year in Granada (Spain) studying Spanish. In 1991 I enrolled as a student of economics at the Free University of Amsterdam (VU), and in 1992 I started studying Spanish at the University of Amsterdam (UvA). In 1994 I received the propedeutic diploma in Spanish and in 1997 I graduated in environmental economics with a thesis on the relationship between tourism and the development of nature parks in Costa Rica. While I was looking for a job, I spent a year campaigning against the physical expansion of the port of Amsterdam. In early 1999 I started my PhD research on tourism at the International Centre for Integrative Studies $(I C \mid S)$, which resulted in this thesis. Currently, I work as a postdoc at ICIS, researching the possibilities for sustainable tourism development in the Antarctic Peninsula. 